DOE/NE/44139-78

SCALED VITRIFICATION SYSTEM III (SVS III) PROCESS

DEVELOPMENT AND LABORATORY TESTS

AT THE WEST VALLEY DEMONSTRATION PROJECT

Topical Report

By

V. Jain

S. M. Barnes

B. G. Bindi

R. A. Palmer

May 2000

Work Performed Under Contract No. AC24-81NE44139

Prepared by

West Valley Nuclear Services Co.

10282 Rock Springs Road

West Valley, NY 14171-9799 


\section{DISCLAIMER}

This report was prepared as an account of work sponsored by an agency of the United States Government. Neither the United States Government nor any agency thereof, nor any of their employees, makes any warranty, express or implied, or assumes any legal liability or responsibility for the accuracy, completeness, or usefulness of any information, apparatus, product, or process disclosed, or represents that its use would not infringe privately owned rights. Reference herein to any specific commercial product, process, or service by trade name, trademark, manufacturer, or otherwise, does not necessarily constitute or imply its endorsement, recommendation, or favoring by the United States Government or any agency thereof. The views and opinions of authors expressed herein do not necessarily state or reflect those of the United States Government or any agency thereof.

This report has been reproduced directly from the best available copy.

Available to DOE and DOE contractors from the Office of Scientific and Technical Information, PO Box 62, Oak Ridge, TN 37831; prices available from (615) 576-8401, FTS 626-8401.

Available to the public from the National Technical Information Service, U. S. Department of Commerce, 5285 Port Royal Road, Springfield, VA 22161. 
DOE/NE/44139-78

Distribution Category UC-510

\title{
SCALED VITRIFICATION SYSTEM III (SVS III) PROCESS DEVELOPMENT AND LABORATORY TESTS \\ AT THE WEST VALLEY DEMONSTRATION PROJECT
}

\author{
Topical Report
}

\author{
By \\ V. Jain
}

S. M. Barnes

B. G. Bindi

R. A. Palmer

May 2000

Work Performed Under Contract No. DE-AC24-81NE 44139

Prepared for

U.S. Department of Energy

Assistant Secretary for Nuclear Energy

Prepared by

West Valley Nuclear Services Co.

10282 Rock Springs Road

West Valley, NY 14171-9799 



\section{TABLE OF CONTENTS}

Section

Page

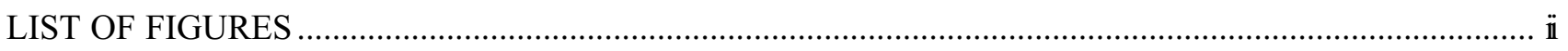

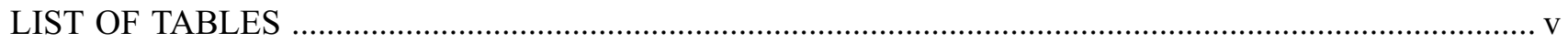

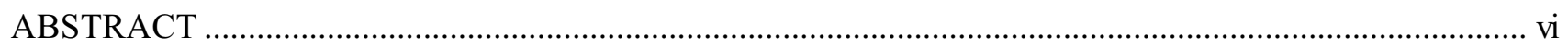

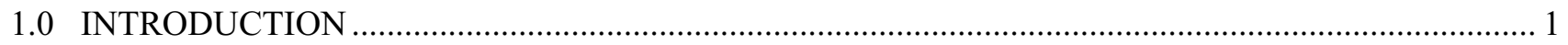

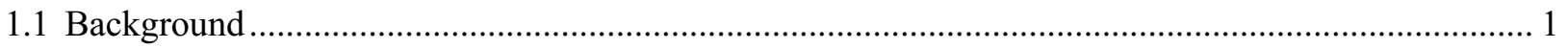

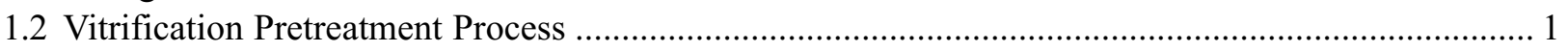

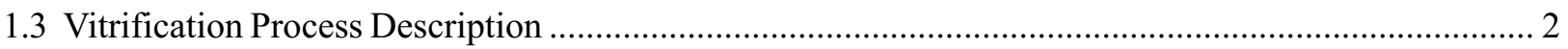

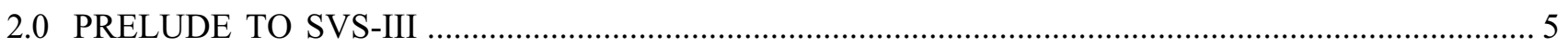

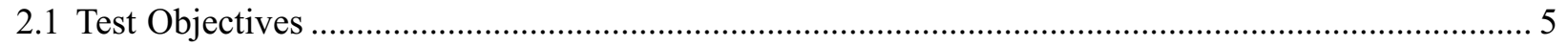

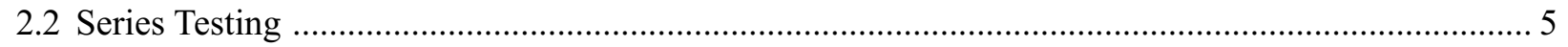

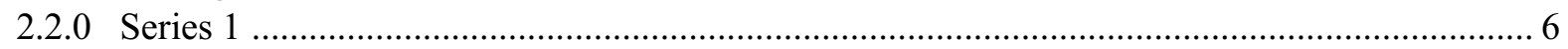

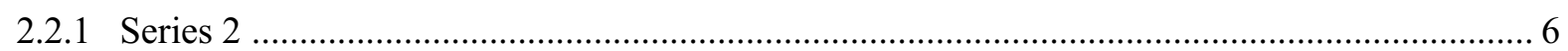

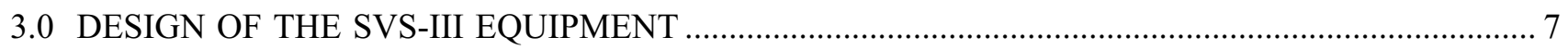

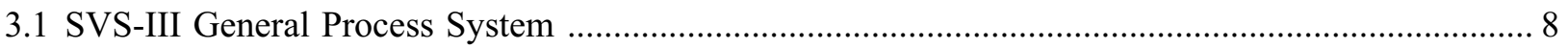

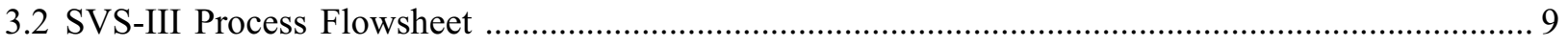

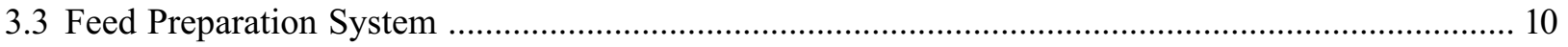

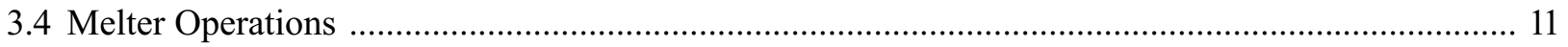

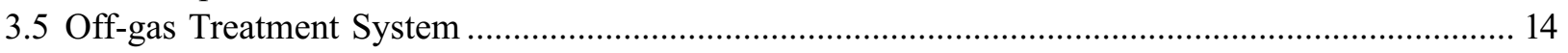

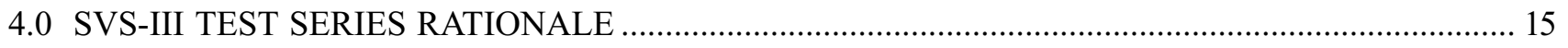

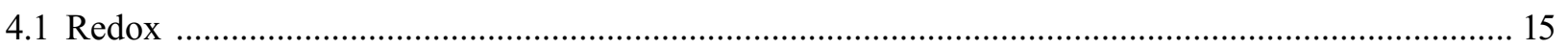

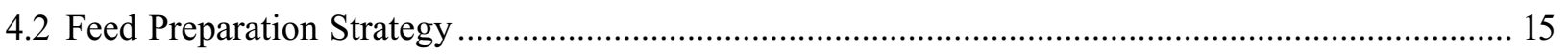

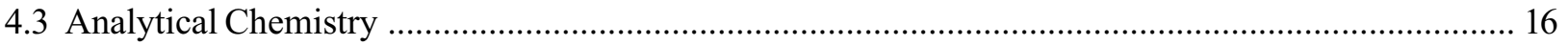

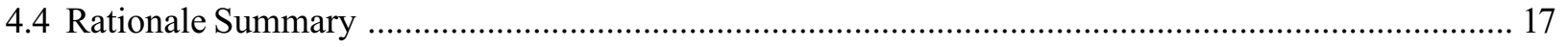

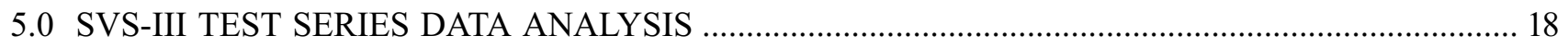

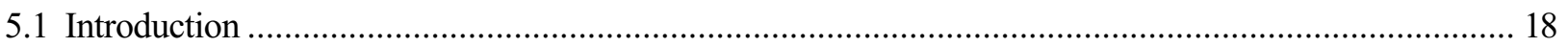

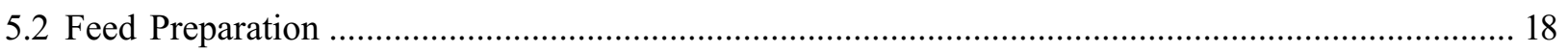

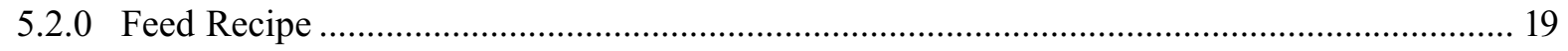

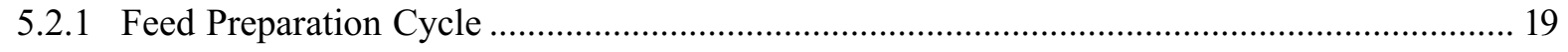

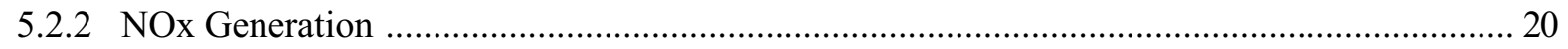

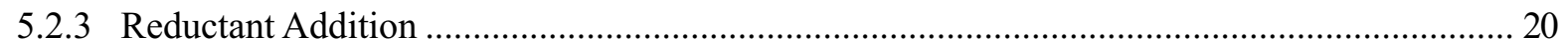

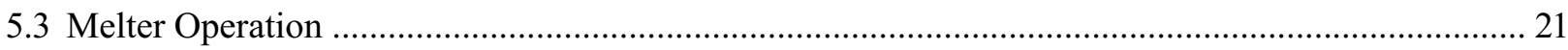

5.3.0 Feed Rate, Cold Cap, Plenum and Internal Glass Temperature, and Melter Power .............. 23

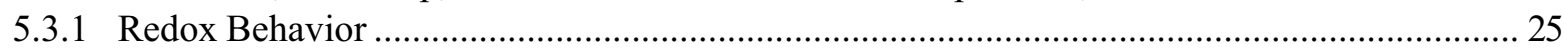

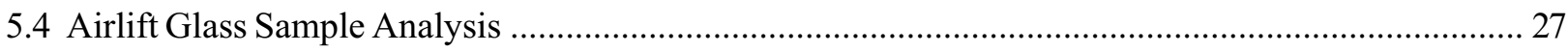

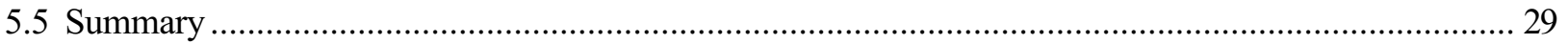

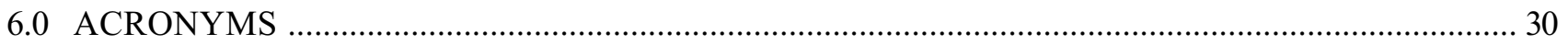




\title{
APPENDIX
}

\author{
APPENDIX A: SVS-III RUN 1-01 \\ APPENDIX B: SVS-III RUN 1-01A \\ APPENDIX C: SVS-III RUN 1-03 \\ APPENDIX D: SVS-III RUNS 1-04 AND 1-04' \\ APPENDIX E: SVS-III RUN 1-05 \\ APPENDIX F: SVS-III RUN 1-06 \\ APPENDIX G: SVS-III RUN 2-01 \\ APPENDIX H: SVS-III RUN 2-02 \\ APPENDIX I: TEST APPARATUS
}

\section{LIST OF FIGURES}

Figure

Page

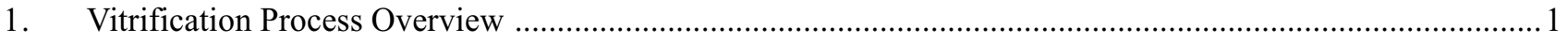

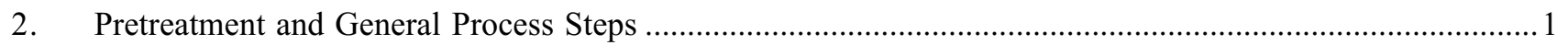

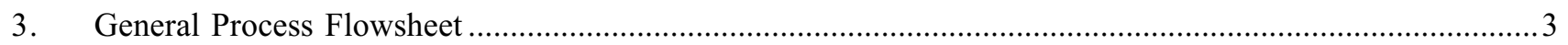

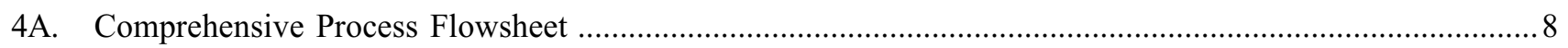

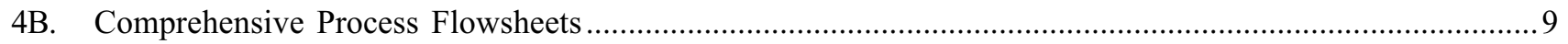

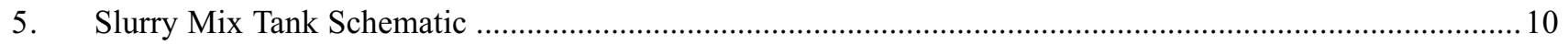

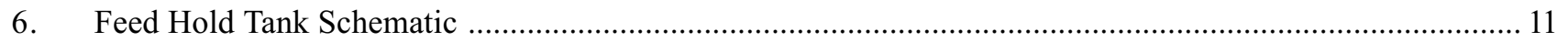

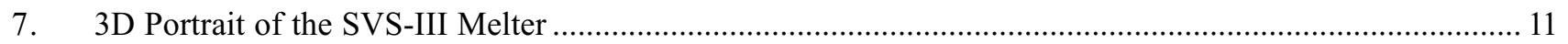

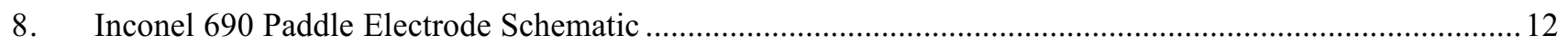

9. Discharge and Plenum Heaters and Melter Electrodes' Placement Schematic ............................................. 12

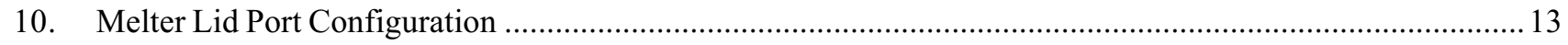

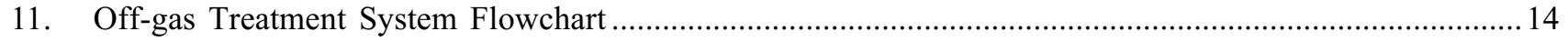

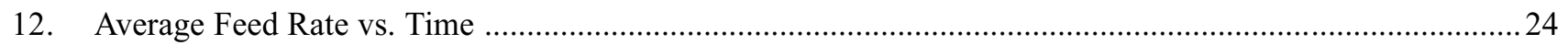

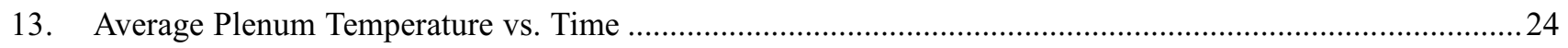

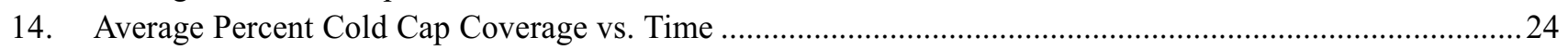

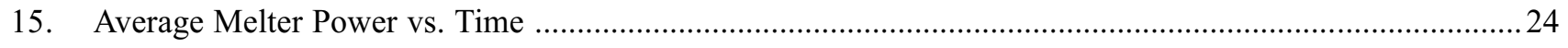

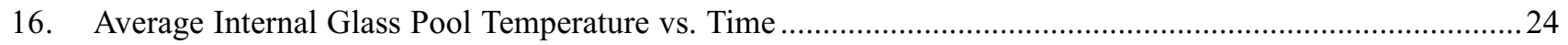

17. Redox Curves for Slurry-Fed Ceramic Melter (SFCM), SVS-I, and SVS-III .........................................25

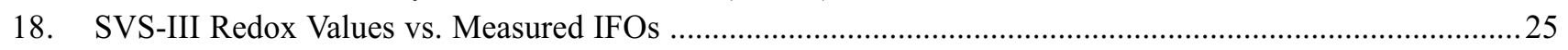

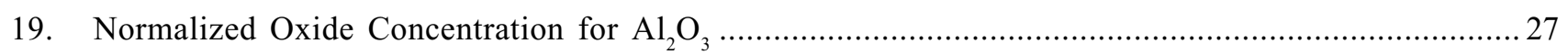

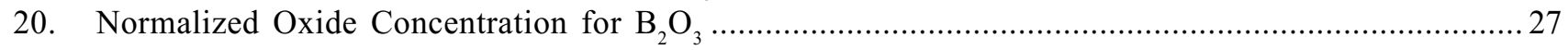

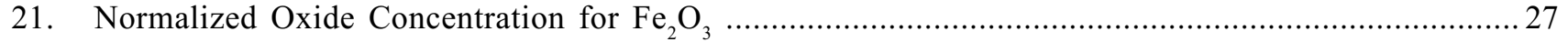

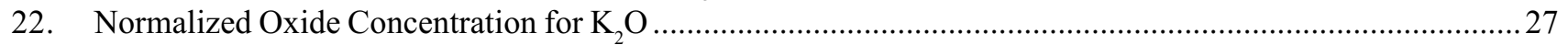

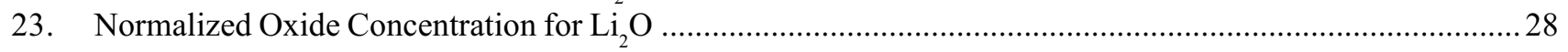

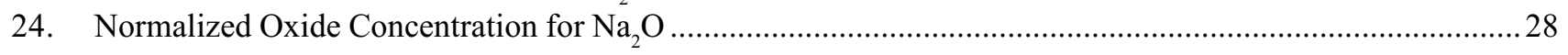

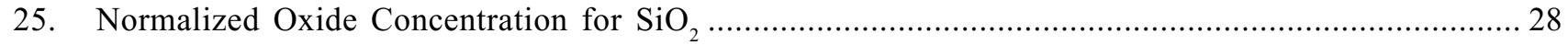

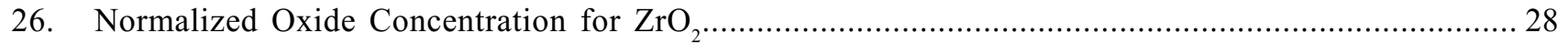




\section{LIST OF FIGURES}

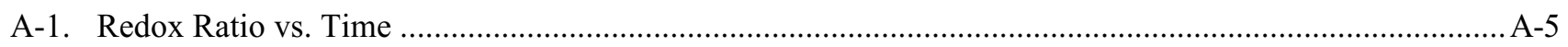

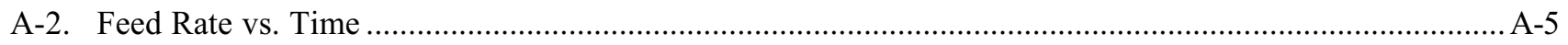

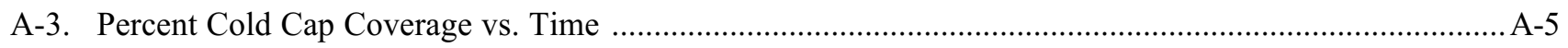

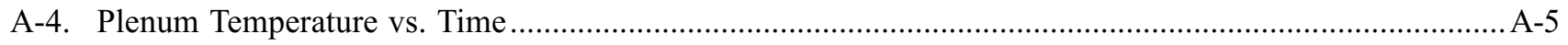

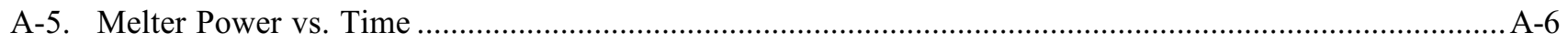

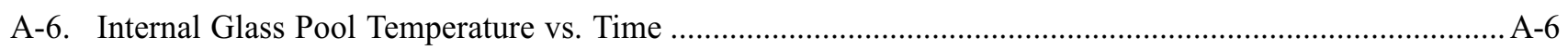

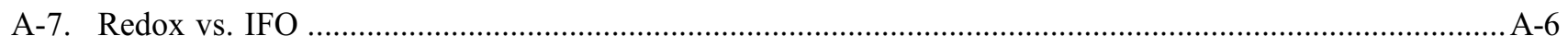

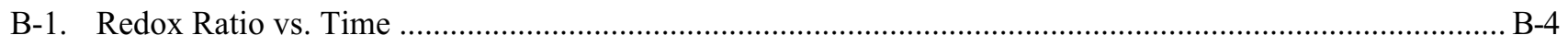

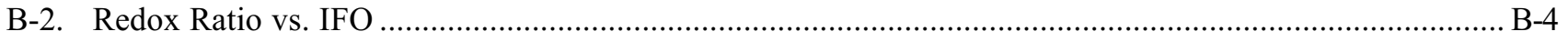

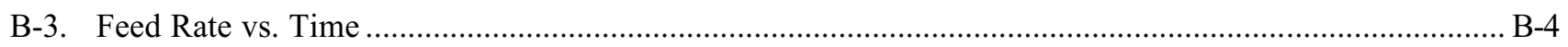

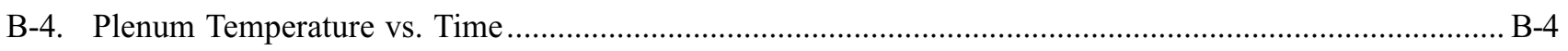

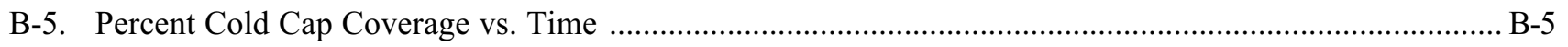

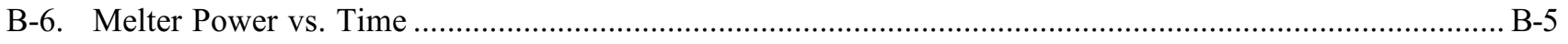

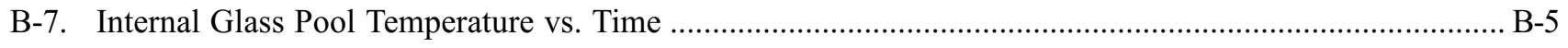

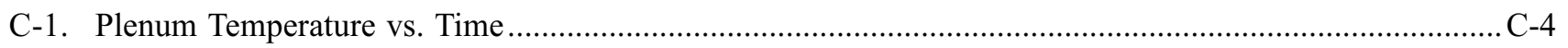

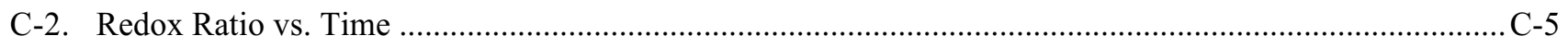

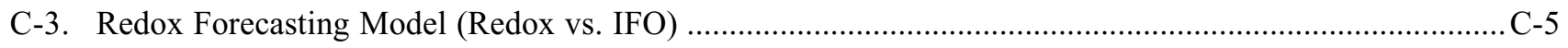

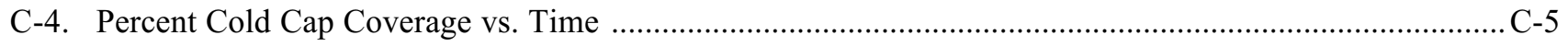

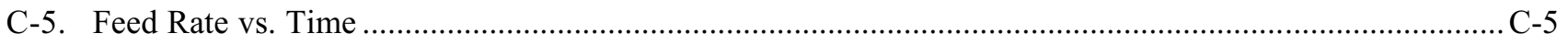

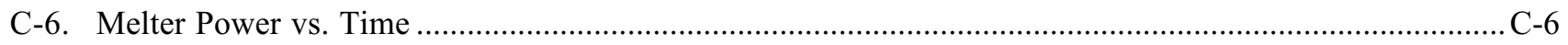

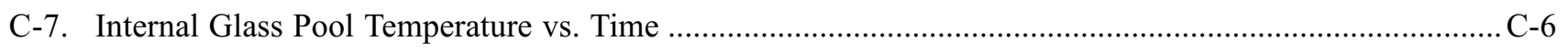

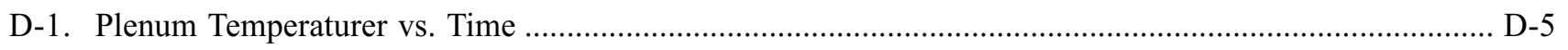

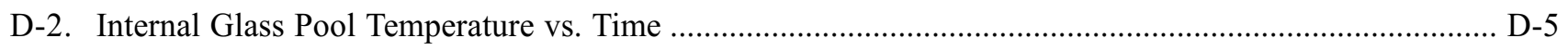

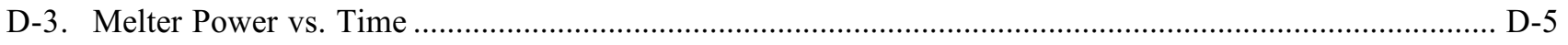

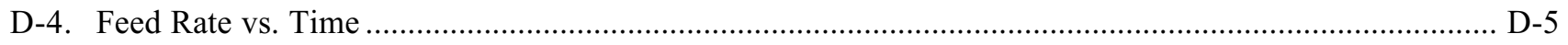

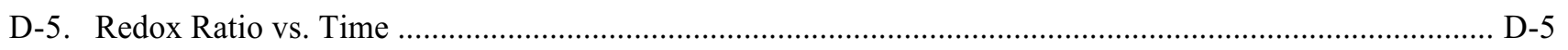

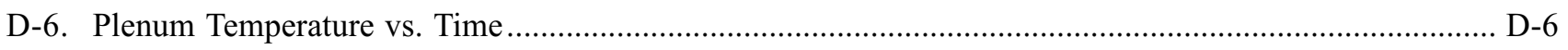

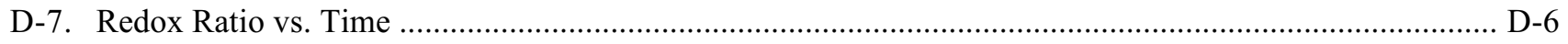

D-8. Percent Cold Cap Coverage vs. Time …….................................................................................. D

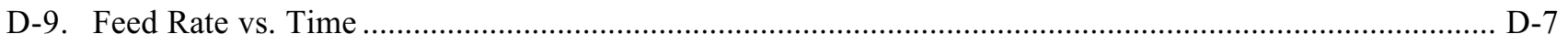

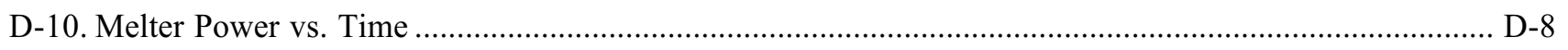

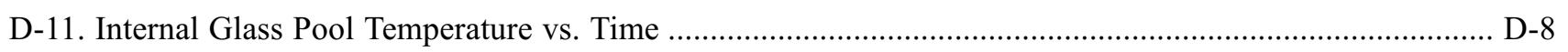

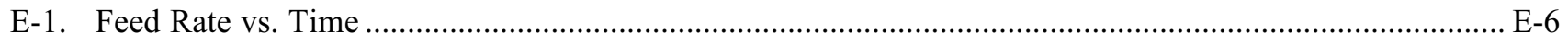

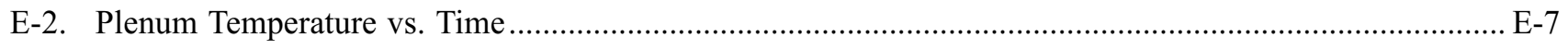

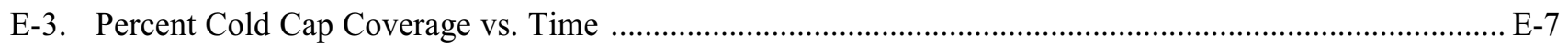

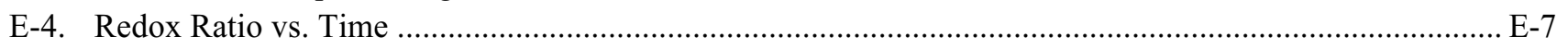

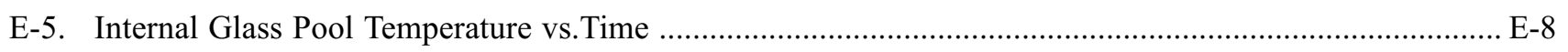

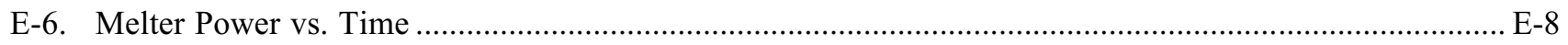

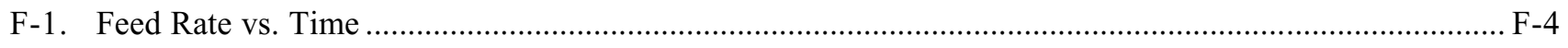

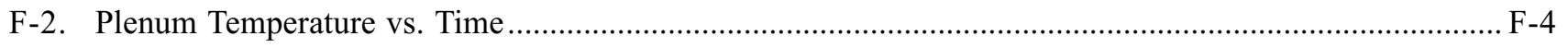

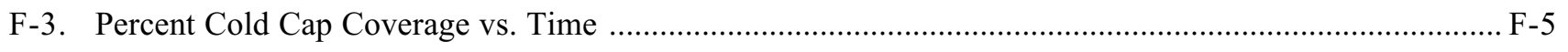

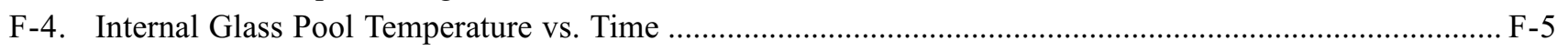

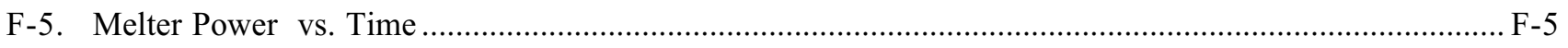

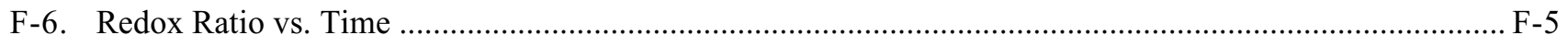




\section{LIST OF FIGURES (cont.)}

Figure

Page

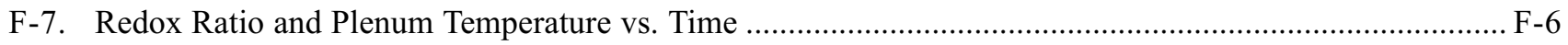

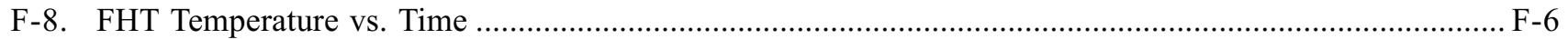

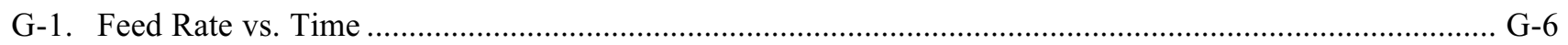

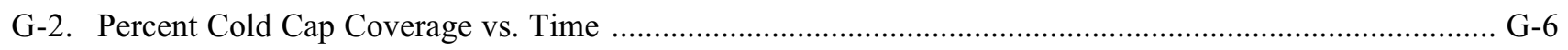

G-3. Plenum Temperature vs. Time

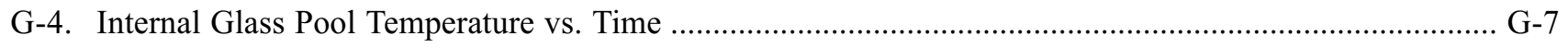

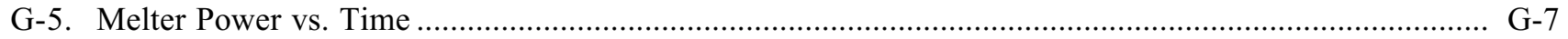

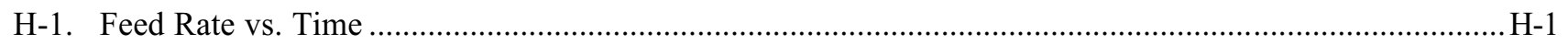

H-2. Plenum Temperature vs. Time for Foaming Incident ….............................................................

H-3. NOx Concentration vs. Time for Foaming Incident …...................................................................

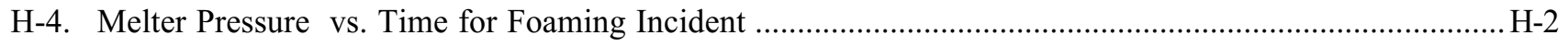

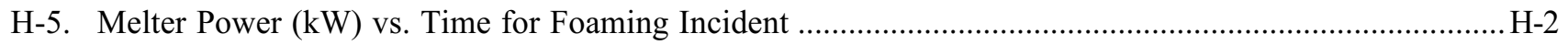

H-6. Melter Power (volts) vs. Time for Foaming Incident …................................................................

H-7. Melter Power (amps) vs. Time for Foaming Incident ….......................................................................

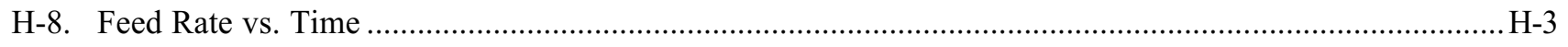

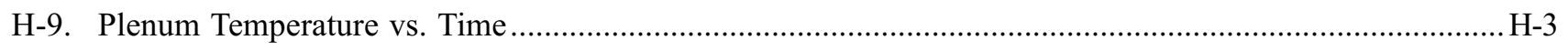

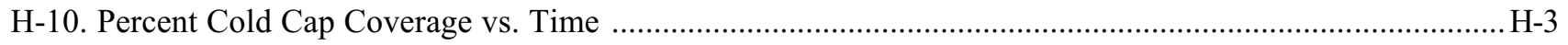

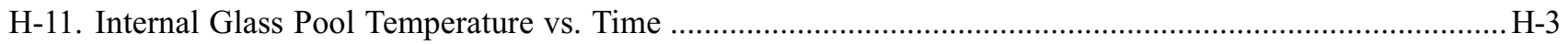

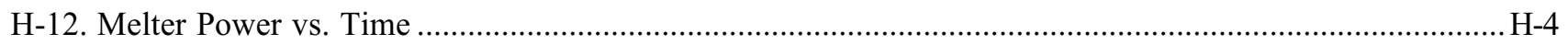




\section{LIST OF TABLES}

Table

Page

Table 1 Description of the SVS-III Testing Runs (Based on the FACTS Redox Forecasting Model) ............. 6

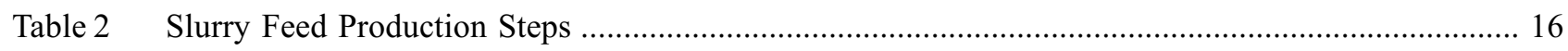

Table 3 Typical Sequence of Addition for Waste Simulant .................................................................... 17

Table 4 Typical Sequence of Addition for Glass-Formers ...................................................................... 17

Table 5 Target Glass Composition for SVS-III Testing ............................................................................ 19

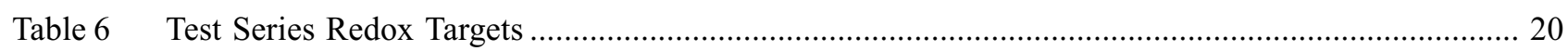

Table 7 Typical Nitrate Balance in a SVS-III Slurry ............................................................................. 21

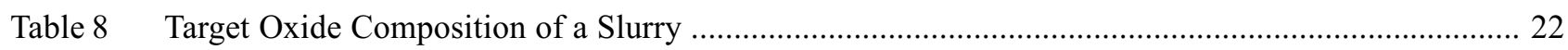

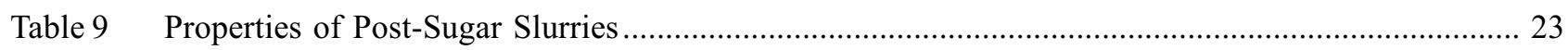

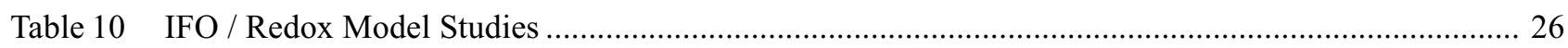

Table A-1. Chemical Analysis of Glass-Former Slurry (weight \% basis) ....................................................... A-2

Table A-2. Variation in Major Components of the Glass-Former Slurry ……............................................. A-2

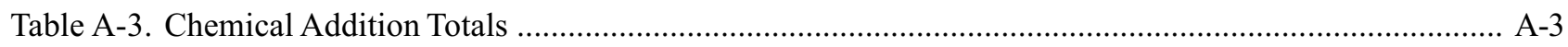

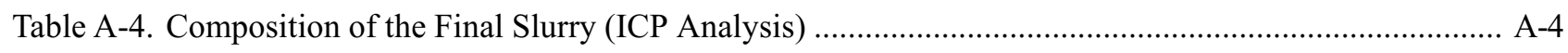

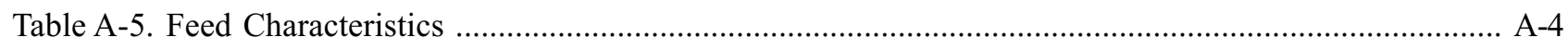

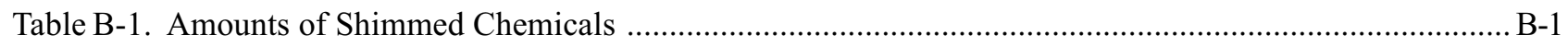

Table B-2. ICP Analysis of Vitrified Feed Samples from FHT (weight \% basis) ............................................. B-2

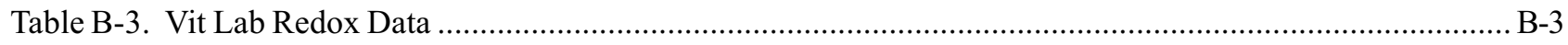

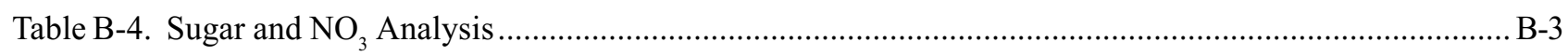

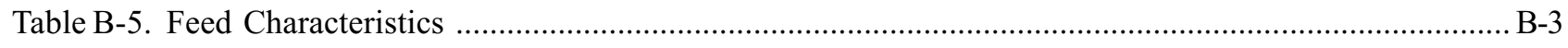

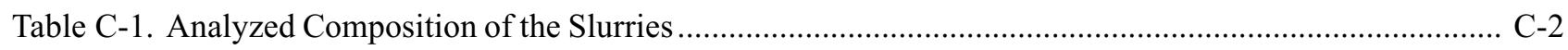

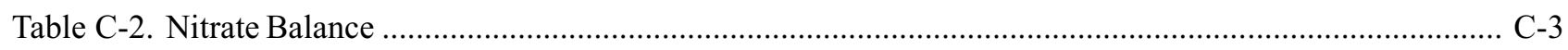

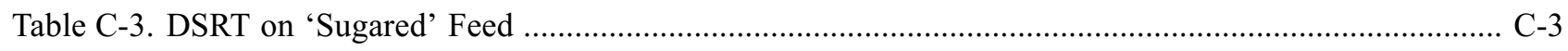

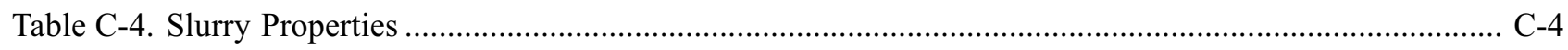

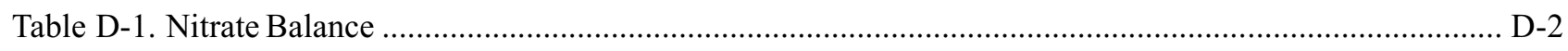

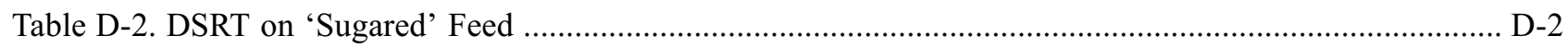

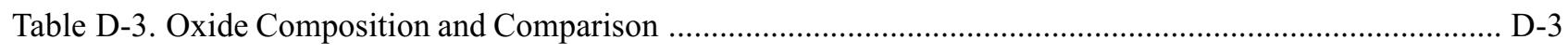

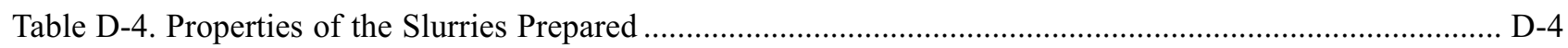

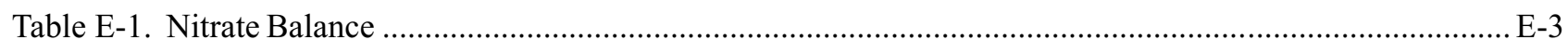

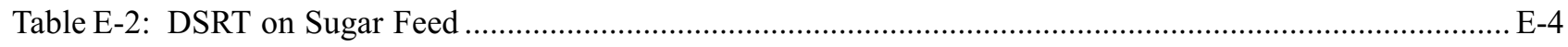

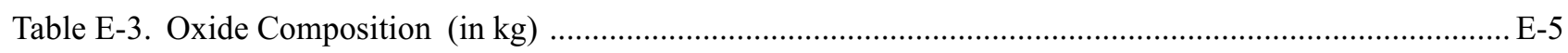

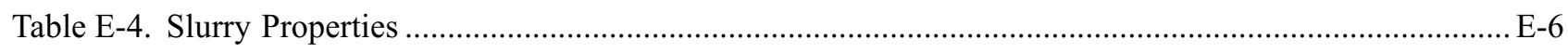

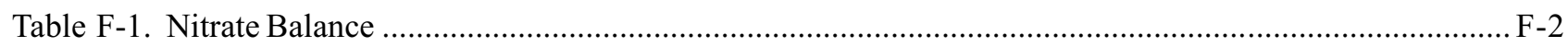

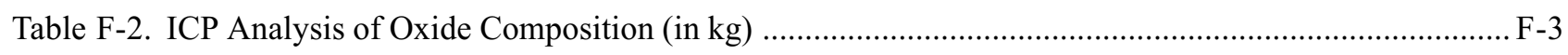

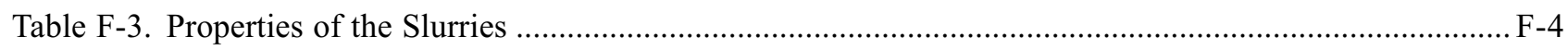

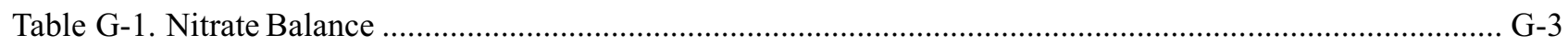

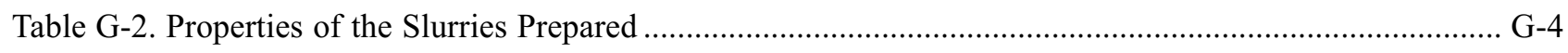

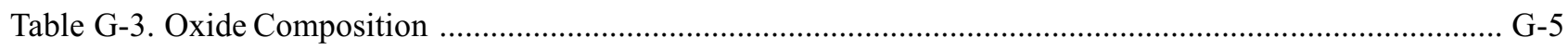




\section{ABSTRACT}

At the West Valley Demonstration Project (WVDP), the Vitrification Facility (VF) is designed to convert the high-level radioactive waste (HLW) stored on the site to a stable glass for disposal at a Department of Energy (DOE)- specified federal repository. The Scaled Vitrification System III (SVS-III) verification tests were conducted between February 1995 and August 1995 as a supplemental means to support the vitrification process flowsheet, but at only one seventh the scale. During these tests, the process flowsheet was refined and optimized.

The SVS-III test series was conducted with a focus on confirming the applicability of the Redox Forecasting Model, which was based on the Index of Feed Oxidation (IFO) developed during the Functional and Checkout Testing of Systems (FACTS) and SVS-I tests. Additional goals were to investigate the prototypical feed preparation cycle and test the new target glass composition.

Included in this report are the basis and current designs of the major components of the Scale Vitrification System and the results of the SVS-III tests. The major subsystems described are the feed preparation and delivery, melter, and off-gas treatment systems. In addition, the correlation between the melter's operation and its various parameters; which included feed rate, cold cap coverage, oxygen reduction (redox) state of the glass, melter power, plenum temperature, and airlift analysis; were developed. 


\subsection{INTRODUCTION}

\subsection{Background}

In 1980, Congress established the West Valley Demonstration Project (WVDP) through Public Law 96-368 as a U.S. Department of Energy (DOE) high-level radioactive waste (HLW) management project to be conducted in West Valley, NY. The DOE contracted West Valley Nuclear Services Company (WVNS), a subsidiary of Westinghouse Electric Company (WELCO), to manage the Project.

The objective of the WVDP is to solidify the liquid high-level radioactive wastes (HLW) stored at the WVDP and then decontaminate the facilities used in the solidification operations. The HLW, now stored in underground tanks, will be stabilized into a form more suitable for transportation to and long-term storage at a federal repository. In July 1983, the DOE selected borosilicate glass as the waste form. This report describes in detail the Scaled Vitrification System III (SVS-III) facility (a 1/7 model of the full-scale Vitrification Facility $[\mathrm{VF}]$ ) and the SVS-III testing program and results, which optimized the vitrification process flowsheet.

\subsection{Vitrification Pretreatment Process}

The existing HLW at the WVDP resulted from the reprocessing of approximately 640 metric tons of spent nuclear fuel utilizing plutonium uranium extraction (PUREX) processing. The HLW was chemically neutralized and adjusted to a desired $\mathrm{pH}$ with sodium hydroxide. The neutralized waste was then discharged to underground storage Tank 8D-2.

During the neutralization of this HLW, the insoluble metal hydroxides precipitated to the floor of Tank $8 \mathrm{D}-2$ forming a layer of sludge. The solution above the sludge layer, or supernatant, contained soluble salts composed predominantly of sodium nitrate. The primary radionuclide in the supernatant was cesium (see Figure 1).

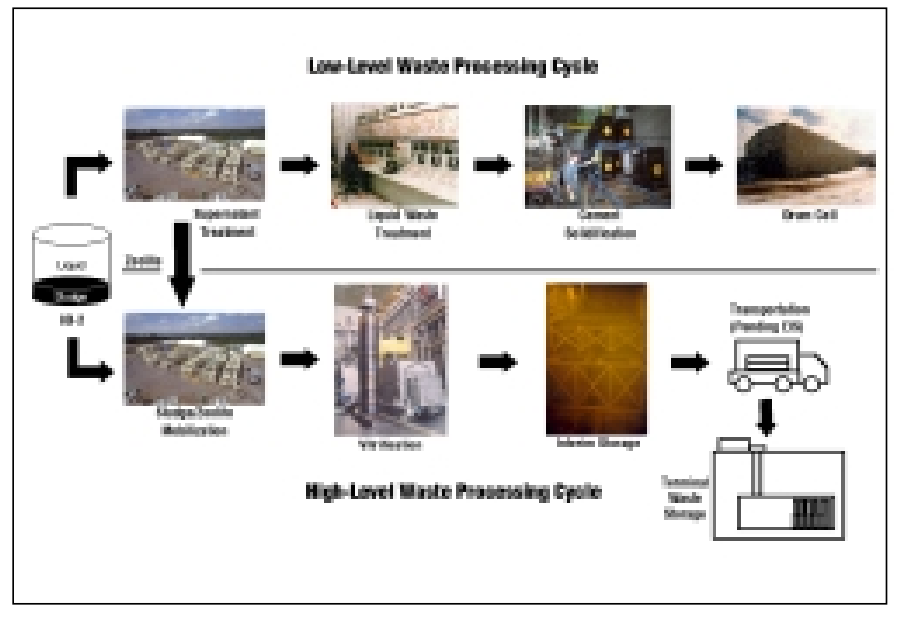

Figure 1. Vitrification Process Overview

Pretreatment steps were taken with the goal of reducing the volume of the HLW. These steps are illustrated in Figure 2. The process began by decanting the supernatant from Tank $8 \mathrm{D}-2$ and directing the supernatant through zeolite ion-exchange columns in Tank 8D-1. These columns removed more than $99 \%$ of the radioactive cesium.

Figure 2. Pretreatment and General Process Steps

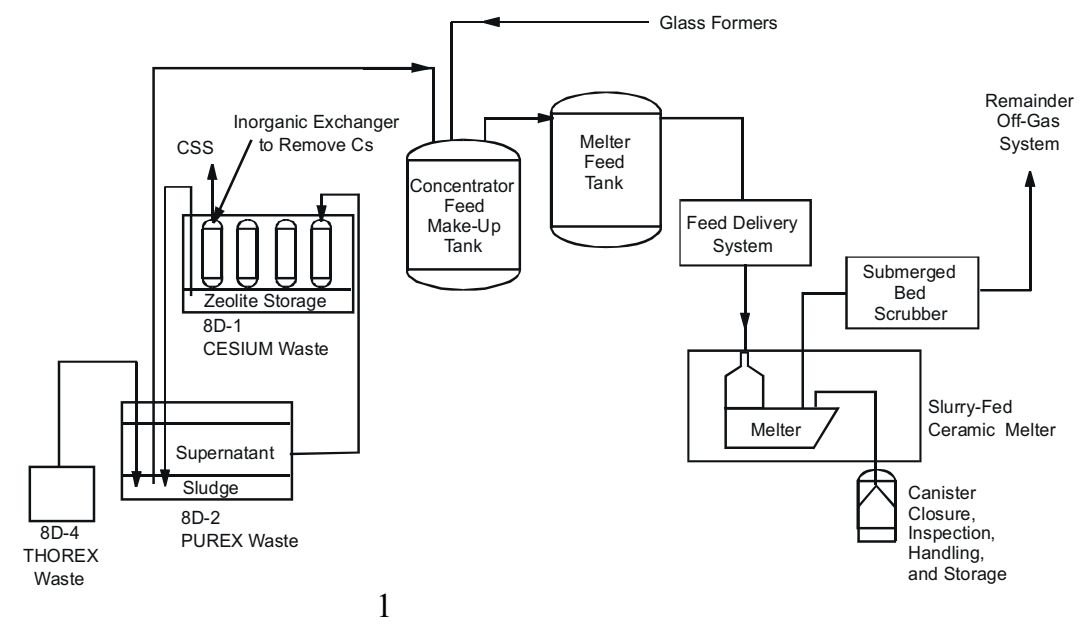


The decontaminated supernatant was then transferred to the Low-Level Waste Treatment Facility (LLWTF) where it was stabilized in cement. Once the zeolite ion-exchange columns were loaded with cesium, they were discharged to the floor of Tank $8 \mathrm{D}-1$. After the $8 \mathrm{D}-2$ supernatant was treated by decanting, water was used to wash low-solubility salts, such as sulfates. The sludge was then allowed to settle to the floor once again after the sludge was washed. The supernatant resulting from these washings was pumped back into the zeolite ion-exchange columns where the whole process was repeated. After washing the sludge two times and decontaminating the water, the utilization of the zeolite was complete.

Tank 8D-4 contained approximately 45,400 liters of thorium extraction (THOREX) waste that resulted from the reprocessing of thorium fuel by Nuclear Fuel Services, Inc. (NFS). In the reprocessing process, it was the nitric acid solution containing the thorium that was not recovered. After blending the THOREX waste with the 8D-2 sludge, the resultant blend was then washed one more time to remove sulfate salts.

After washing the blend of neutralized HLW THOREX waste and washed HLW sludge in Tank 8D-2, the zeolite was then transferred from Tank 8D-1 to Tank 8D-2 where it was homogenized with the in-tank mobilization equipment.

\subsection{Vitrification Process Description}

The feed make-up process (see Figure 3) starts with a transfer of a sufficient amount of the blended waste to the Concentrator Feed Make-up Tank (CFMT) to allow about 200 hours of melter feed operation. The general process flowsheet is shown in Figure 3. In routine operation, the process in the feed make-up system is a batch activity, but the melter is essentially fed continuously.

Prior to the transfer of waste from Tank $8 \mathrm{D}-2$, recycled slurry from the off-gas scrubbing equipment is combined with the forementioned waste in the CFMT. This combined waste slurry is mixed with the residual heel from the previously prepared batch. After the HLW is transferred to the CFMT from Tank 8D-2, a representative sample is obtained. As the sample is being analyzed, the waste slurry is concentrated by boiling off the excess water.

When the analysis is complete, chemical additions are made from a cold chemical facility to yield a glass composition that falls within the qualified compositional range. These chemicals are prepared, analyzed, and transferred into the CFMT as a slurry and are thoroughly homogenized with the waste. This homogeneous mixture is again sampled. After the elemental composition of the CFMT contents is approved, a calculated amount of sugar is added to the CFMT to control oxidation reduction (redox) in the melter. The contents of the CFMT are resampled for nitrate and total carbon in the feed to ensure that proper redox is maintained in the melter.

After the chemical analysis of the mixture is approved, it is then transferred to the Melter Feed Hold Tank (MFHT). Out of this tank, the melter is fed continuously. The rate of delivery is dependent on the slurry's concentration. The anticipated feed rate range is between 60 and $150 \mathrm{~L} / \mathrm{hr}$.

In the melter, water evaporates from the slurry and the solids calcine. The calcined material melts into the pool and mixes thoroughly. After approximately 60 to 100 hours of mean residence time, which is dependent on the feed rate, the glass is poured into a stainless steel canister. Canisters are positioned under the melter pour spout by the turntable; a four-position, four-canister device. The turntable has one position for filling, two positions for cool-down, and a fourth position for removal and canister replacement. 


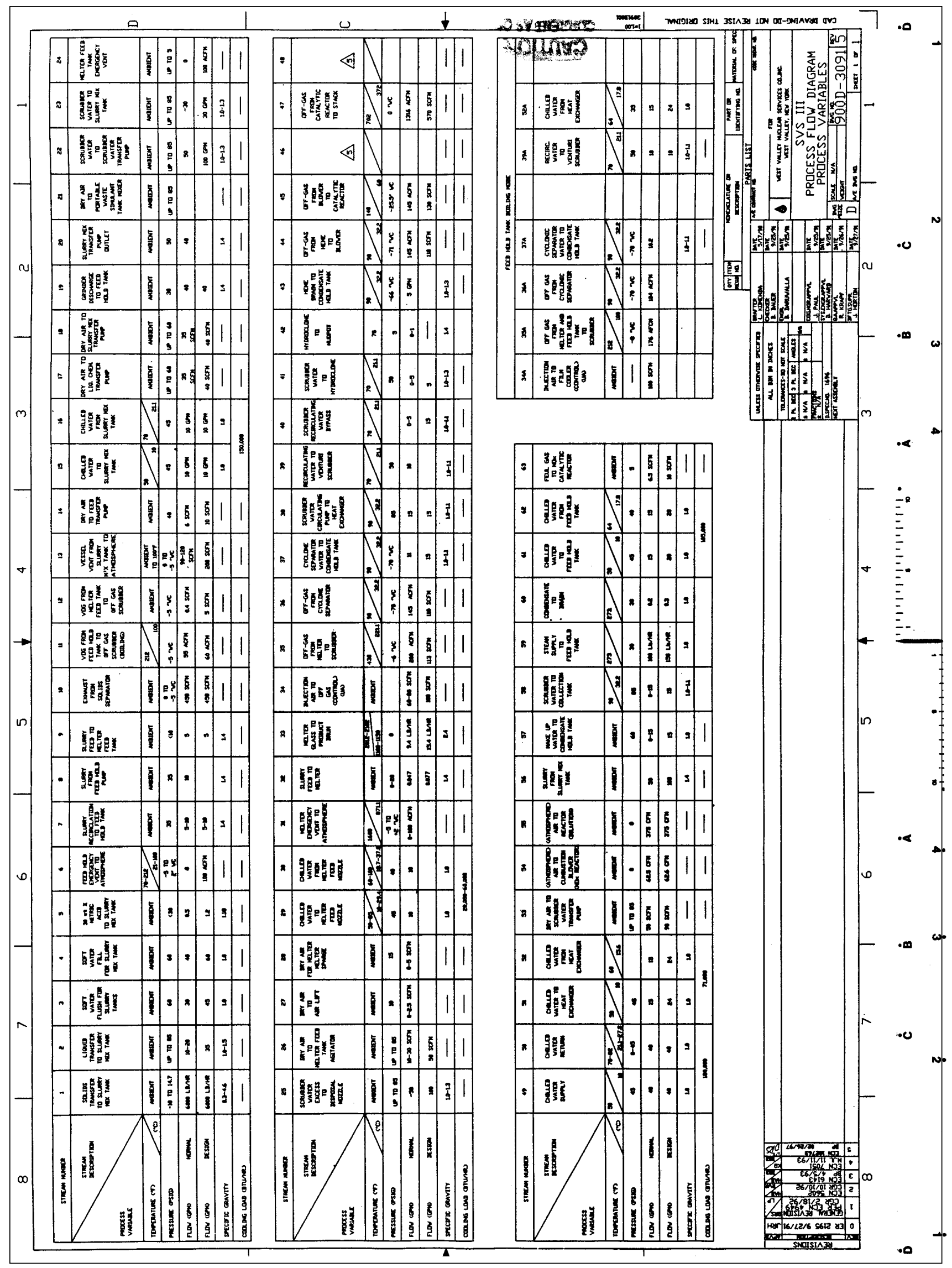

Figure 3. General Process Flowsheet 
After cooling and removal from the turntable, the canister is then transferred to the welding station where it is sampled and the canister lid is remotely welded to the top flange of the canister. The canister is then transferred to the canister decontamination system where the desired level of decontamination is achieved by chemical etching. The canister is then moved, via the transfer cart, to the Chemical Process Cell (CPC) of the former reprocessing plant where it will be in interim storage until its final storage location at a federal repository has been determined. The Vitrification Facility (VF) is expected to produce approximately 500,000 $\mathrm{kg}$ of radioactive glass.

During the melting process, steam, feed carryover, and evolution of volatiles from the melting process are vented to the process off-gas treatment system. The first stage includes a Submerged Bed Scrubber (SBS), where the off-gas is drawn to the bottom of a submerged column of ceramic beads. After the off-gas is allowed to percolate up and be scrubbed by the liquid, it is drawn to the mist eliminator and preheater. This high-efficiency mist eliminator (HEME) removes mist and fine particulate remaining in the off-gas. The off-gas then travels through the high-efficiency particulate air (HEPA) filter to remove particulates. Alternatively, prior to the HEME, the off-gas can be heated above its dew point to eliminate mist.

After passing through the HEPA filters, the off-gas is essentially free of radioactive pollutants. The off-gas then passes to another building, via a $100 \mathrm{~m}$ underground trench, where the oxides of nitrogen $\left(\mathrm{NO}_{\mathrm{x}}\right)$ are removed. A final stage of filtering, HEPA filters, are provided before the off-gases are exhausted out the plant stack. All process vessels, with the exception of the process off-gas equipment, are vented by the vessel vent system. This system maintains the CFMT, MFHT, and other process components under partial vacuum, as well as providing an emergency bypass of the SBS in case the melter off-gas line becomes plugged. The gases first pass through a condenser and then join the process off-gas prior to the mist eliminator-preheater in front of the HEME and process HEPAs. 


\subsection{PRELUDE TO SVS-III}

Since the conclusion of the Functional and Checkout Testing of Systems (FACTS) in December 1989, the FACTS testing facility, known as the Component Test Stand (CTS), has been transformed into a remotely operated facility for vitrifying radioactive slurries. This facility is processing the radioactive wastes currently stored in Tank 8D-2.

The WVDP radioactive waste streams, when mixed with the glass-forming oxides, represent almost the entire spectrum of chemical elements in the Periodic Table. At times, even minor variations in the chemical constitution of the slurry could initiate a series of interactive non-linear effects that may result in a totally different set of chemical characteristics. Such scenarios could drastically reduce glass output and, in some cases, make vitrification impossible.

To avoid such scenarios, the Scaled Vitrification System I (SVS-I) was operated in parallel with the FACTS campaign between 1987 and 1989. During FACTS, the SVS-I was primarily used to support chemistry issues. The SVS testing was instrumental in defining the slurry characteristics (i.e., the required amounts of nitrates, sugar, and water) and in predicting and controlling redox in the melter.

Even though the FACTS program successfully demonstrated the ability of the equipment to endure severe chemical conditions existing in the vitrification process, the complex chemical behavior of the WVDP waste streams during the feed preparation process, as well as during vitrification, were not fully understood during this program.

\subsection{Test Objectives}

In general, the principal reason for having mini-melter tests was to optimize and develop techniques to control the vitrification process during radioactive operation. In these tests, the effects of various components on the mixing behavior of the feed, as well as on the properties of the molten and solid glass, were studied.

The need to operate the Scaled Vitrification System prior to radioactive vitrification operations was a result of the changes in the vitrification process flowsheet that have occurred since the conclusion of the FACTS campaign. Some of the critical changes in the vitrification flowsheet that could impact the processability during radioactive operations are:

- New target glass composition was developed that incorporated the revised estimates for phosphorous and potassium. The revised estimate for phosphorous and potassium were based on the analysis of HLW samples from both Tanks 8D-2 and 8D-1. Even though this new target composition meets all the requirements for waste qualification, the processing characteristics were evaluated.

- Estimates for nitrates and nitrites have been revised to account for additional corrosion inhibitors in the tanks. Since nitrates and nitrites severely impact redox control in the melter, the Redox Forecasting Model has to be reevaluated to incorporate new levels of nitrates and nitrites.

\subsection{Series Testing}

The objectives of the SVS-III Testing Series were to evaluate:

- Process feed chemistry characteristics using the Reference 6 target composition 
- Redox characteristics of the modified process flowsheet and verify empirical models for the Redox Forecasting Model

- Sensitivity analysis of the feed parameters in the Redox Forecasting Model

- Control of the redox $\left(\mathrm{Fe}^{+2} / \mathrm{Fe}^{+3}\right)$ ratio in the glass.

Each run of the SVS-III testing series has its own primary objective in the vitrification process. The test run objectives are given below:

\subsubsection{Series 1}

The objective of the first series of SVS-III testing is to evaluate the model for redox prediction that was developed during the FACTS tests. A range in redox conditions can be induced in the glass melt by strategically controlling the level of sugar input. Utilizing the previous model as a basis, the amount of sugar will be altered to establish specific redox conditions in the melt. The results provided by this series of tests will either confirm the present model or provide a basis for the revised model. Nevertheless, both outcomes will lead to better control of the melter during radioactive operations.

\subsubsection{Series 2}

The objective of the second set of SVS-III tests is to observe the shifts in the redox behavior by varying parameters, such as the amount of nitrates and total solids, to gain a better understanding of redox behavior.

Table 1 gives a description of the projected SVS-III testing runs. Note that the established targets for the projected test runs were revised to account for the unexpected behavior observed in the initial runs. These are discussed in Section 5.0.

Table 1: Description of the SVS-III Testing Runs (Based on the FACTS Redox Forecasting Model)

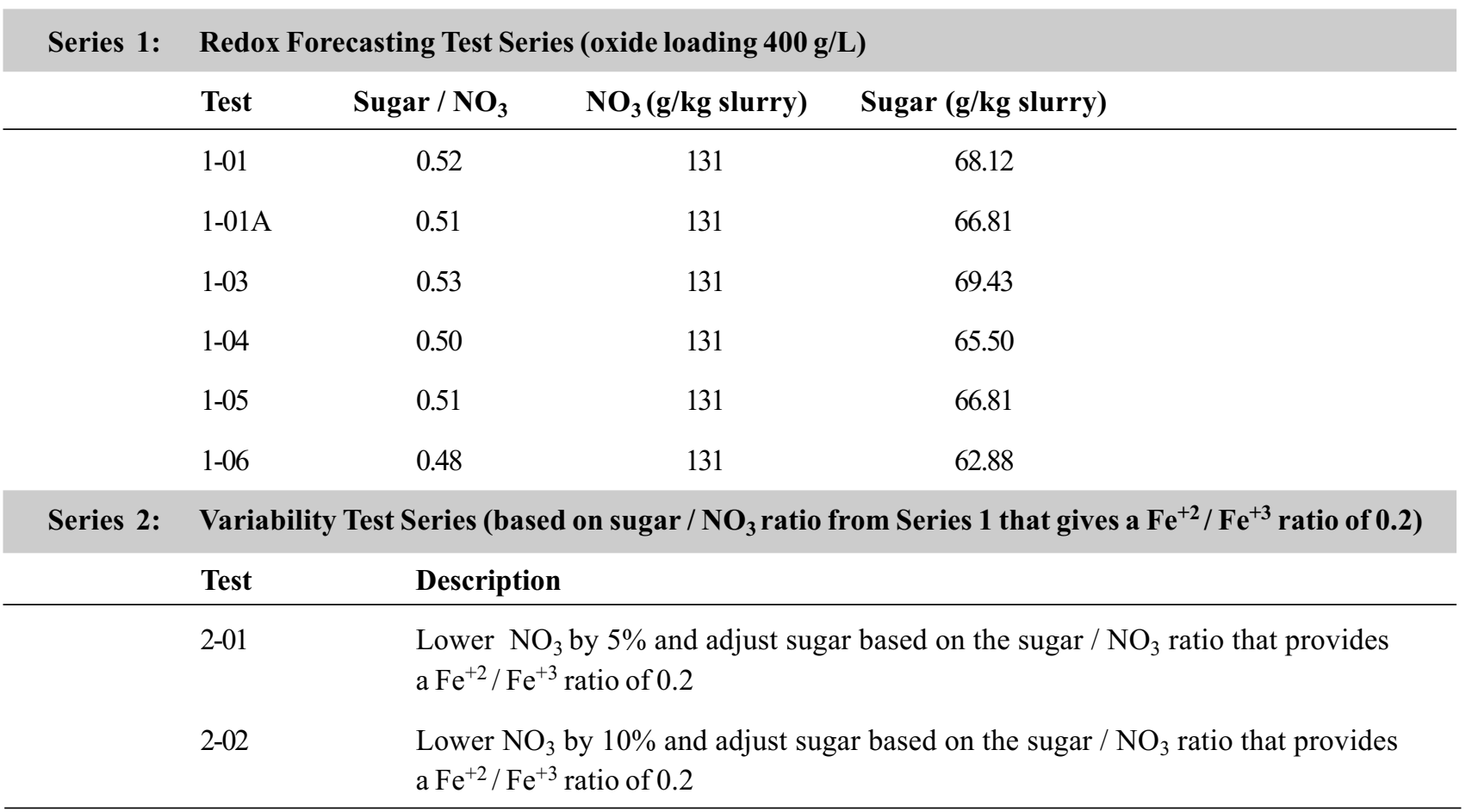




\subsection{DESIGN OF THE SVS-III EQUIPMENT}

The SVS-III used the same Joule-heated ceramic melter (61-V-01) that was used in the SVS-II. The SVS-III is located in bays 4 through 6 on the east end of the Vitrification Test Facility (VTF). Unlike previous scale melter systems though, the SVS-III has its own feed preparation and off-gas treatment systems.

The SVS-III was set up to operate on a weekly basis; preparing feed and making glass on alternate weeks. The equipment was not sized for concurrent operation.

There are three main sub-systems involved in the SVS-III. They are the feed preparation, melter operations, and off-gas treatment systems.

Feed Preparation includes:

- The addition of dry chemicals to the slurry mix tank (SMT 61-D-01) using a pneumatic conveying system (Vac-U-Max $\left.{ }^{\circledR}, 61-\mathrm{V}-16\right)$

- The addition of liquids to the SMT, including waste simulant and nitric acid, using Pumps 61-G-01, 61-G-03, and 61-G-10

- The ventilation system (61-V-12) for the SMT

- Inter and intra tank slurry transfers

- Volume reduction through boiling down the feed hold tank (FHT, 61-D-04)

- The addition of sugar in the FHT to control the redox ratio

- The measurement of off-gas generation during these steps.

Melter Operations include:

- Joule-heated melter (61-V-01)

- Feed handling

- Power control

- Glass discharge to drums on a conveyor (61-V-03).

The off-gas treatment system includes:

- Collecting vapors from the FHT, melter feed tank (MFT, 61-D-06), and melter

- Quenching the vapors by sending them through a venturi scrubber (61-C-16)

- Removing the moisture in a high-efficiency mist eliminator (HEME, 61-V-17)

- Handling the scrubber water that is used by the venturi and is collected from the HEME

- Operation of the off-gas blower (61-K-11) that collects these vapors

- Reducing the nitrogen oxide $\left(\mathrm{NO}_{\mathrm{x}}\right)$ concentration of these vapors in a selective catalytic reactor (SCR, 61-C-14) 
- Controlling the flow of ammonia $\left(\mathrm{NH}_{3}\right)$ to the SCR

- Monitoring the effectiveness of the treatment process using the $\mathrm{NO}_{\mathrm{x}}$ analyzers.

Several safety features have been built into the SVS-III. The VTF floor slopes down to the north wall where a 6-inch berm is located. This provides sufficient volume to contain the entire contents of all vessels that will be used in the SVS-III. The feed pump to the melter will automatically shut down in the event of high melter pressure, low scrubber water flow, or failure of the off-gas treatment system. Emergency vents are located on the FHT, MFT, and melter to exhaust vapors outside the VTF if excessive pressure should develop in them. Separate enclosures for the Distributive Control System (DCS), nitrogen oxide $\left(\mathrm{NO}_{\mathrm{x}}\right)$ analyzers, and ammonia $\left(\mathrm{NH}_{3}\right)$ storage were used to provide the proper environment for human health, equipment, and building safety concerns.

Appendix J gives a complete listing of the major system components.

\subsection{SVS-III General Process System}

The major components of this system consist of the slurry mix tank (SMT), feed hold tank (FHT), melter feed tank (MFT), melter, and an off-gas treatment system. The full, comprehensive flowsheets for the entire SVS-III process are given in Figures 4A and 4B.

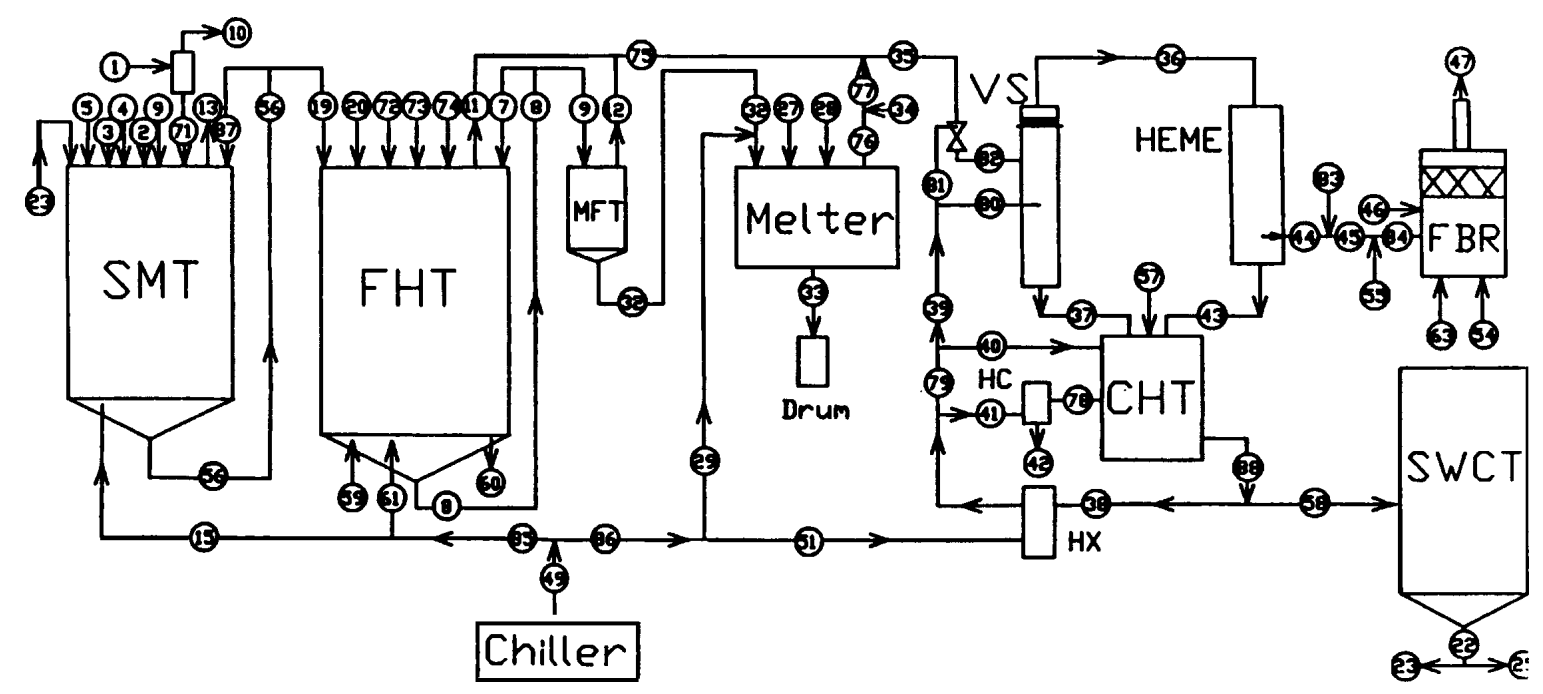

Figure 4A. Comprehensive Process Flowsheet 

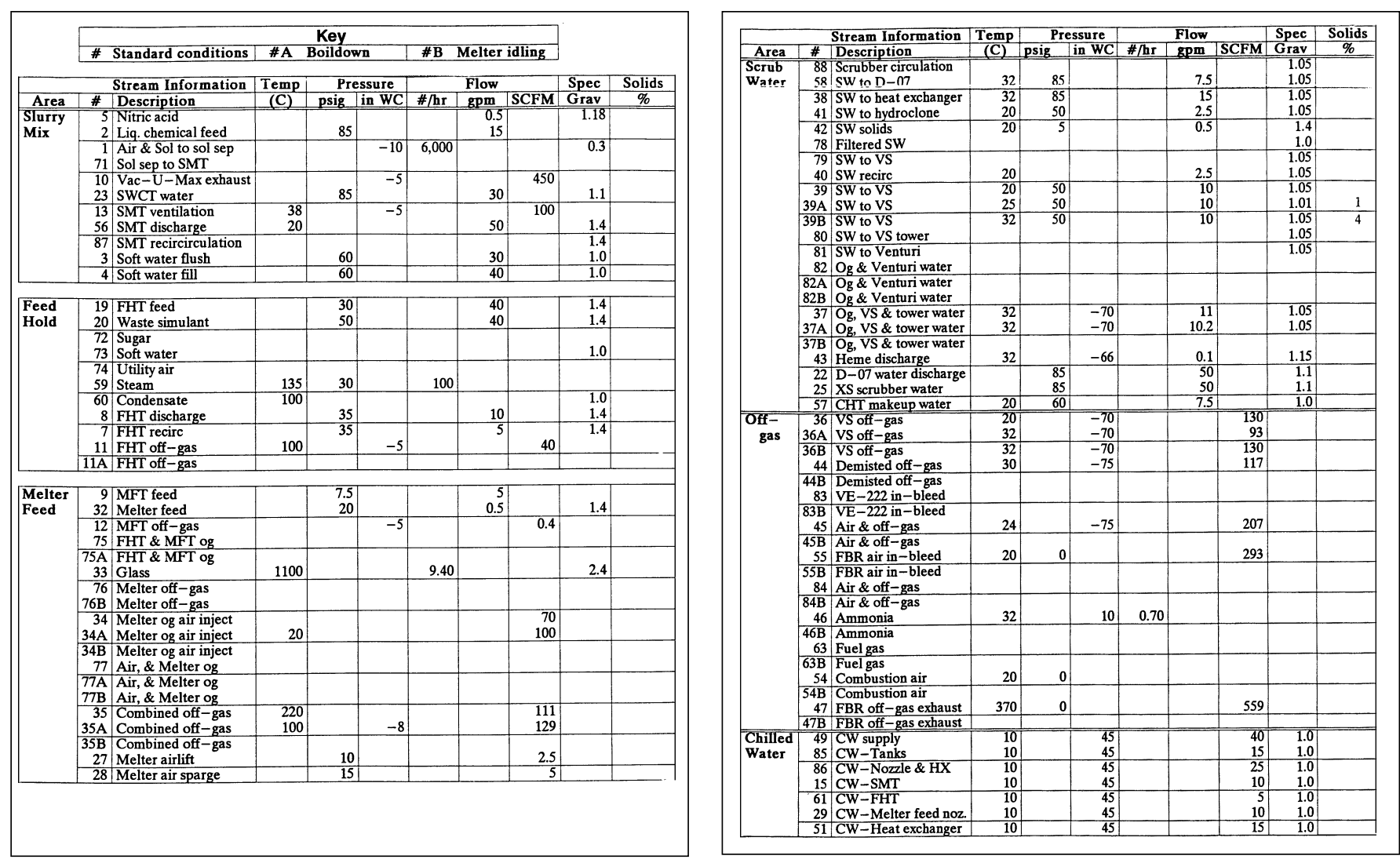

Figure 4B. Comprehensive Process Flowsheets

\subsection{SVS-III Process Flowsheet}

SVS-III, the third Scaled Vitrification System to be used at WVDP, is a pilot plant-scaled system designed to be a Joule-heated, slurry vitrification system that will operate prior to radioactive operations and be independent of the full-scale vitrification system. SVS-III was not used to process radioactive wastes. It incorporates several operational features of the full-scale system.

SVS-III includes its own slurry preparation system, off-gas treatment system, and distributive control system (DCS). These are similar to those installed on the full-scale vitrification system. The Vitrification Test Facility (VTF) houses the SVS-III.

The process starts by mixing and preparing waste simulant using the slurry mix tank (SMT). The chemicals are added to the SMT using either the Vac-U-Max ${ }^{\circledR}$ system or a liquid pump. The Vac-U-Max ${ }^{\circledR}$ is a pneumatic granular transfer device. After simulant preparation is complete, it is sampled and analyzed. While the sample analysis is in progress, waste simulant is transferred, via a grinder, to the feed hold tank (FHT) to be concentrated by maximizing the percent of total solids (\% TS) in the waste. The addition of sodium metasilicate to the waste simulant helps to maximize the $\% \mathrm{TS}$. Contents are concentrated at $\sim 100^{\circ} \mathrm{C}$ using steam coils. After concentration, the simulant is allowed to cool to room temperature.

Next, based on the waste simulant analysis, glass-forming chemicals are calculated to produce a Reference 6 target glass composition. Glass-formers are added in a similar fashion as the waste simulant. The completed glass-former batch is sampled and analyzed. After the waste and glass-former analyses are combined and the results indicate a mix having the composition within the target region, the glass-formers are transferred to the FHT using the grinder. 
The combined slurry is sampled in the FHT and analyzed for 15 cations, $\mathrm{NO}_{3}$, total organic carbon (TOC), density, and \% TS. Based on the TOC, $\mathrm{NO}_{3}$, and \% TS, sugar is added to the FHT and mixed. The mixture is again sampled to ensure the proper $\mathrm{NO}_{3} / \mathrm{TOC}$ ratio. If the ratio is within the test parameters, the feed is transferred to the melter feed tank (MFT).

Slurry from the MFT is metered into the melter and processed into glass. Both glass and vapors exit the melter as a result of the processing. Glass is poured into a canister beneath the melter and vapors go through the SVS-III off-gas treatment system. The melter operates by passing an electrical current through molten glass that generates enough heat to keep the glass at the melt temperature while transforming slurry into glass. This is called Joule heating and is similar to the heating method used in the full-scale melter. The SVS-III melter has a throughput between 4 to $12 \mathrm{~kg}$ of glass per hour, which is approximately $1 / 7$ of the full-scale melter. The glass processing temperature is about $1,150^{\circ} \mathrm{C}$, the same as the full-scale melter.

Exhaust gases are composed of particles and vapors that are by-products of glass production. The gases contain water vapor, carbon dioxide, $\mathrm{NO}_{\mathrm{x}}$, other gases, and granular particles from the slurry. These exhausts pass through a series of treatment devices that make up the off-gas treatment system. A venturi scrubber and HEME are the first two off-gas treatment devices. The venturi scrubber is a water-scrubbing device that will condense vapors and remove coarse particles from the off-gas stream. A HEME, the second off-gas device, is a large, enclosed fiberglass filter after the venturi scrubber that will remove condensate and fine particles. The final off-gas treatment device, a selective catalytic reactor (SCR), treats $\mathrm{NO}_{\mathrm{x}}$ gas to reduce its exhaust concentration.

\subsection{Feed Preparation System}

All free flowing powders were handled using the Vac-U-Max ${ }^{\circledR}$. Powders were typically delivered in 55gallon drums. These drums were positioned on a calibrated scale that controlled the amount of feed to the SMT based on loss in weight. A pneumatic conveyor pick-up wand placed in the drums provided the means of transport. The powder was picked up by the vacuum in the wand and discharged by a solid separator stationed immediately above the SMT. The collection hopper, transfer lines, and filter are made of stainless

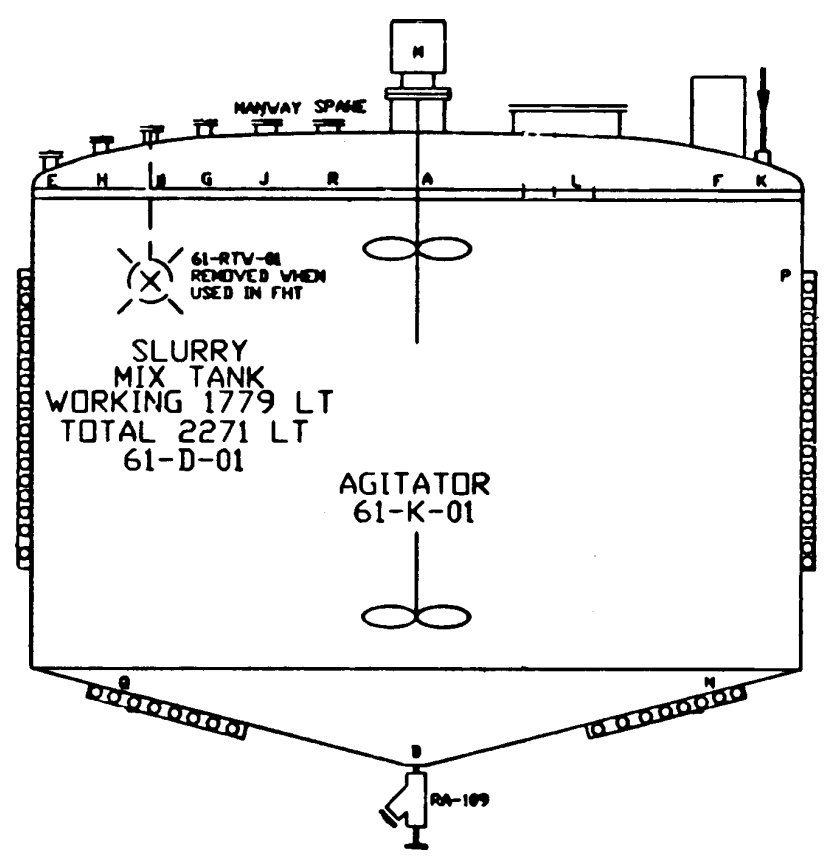

Figure 5. Slurry Mix Tank Schematic steel to ensure chemical purity and to make cleaning easier. The flexible portion of the wand is made of polyethylene.

Liquid chemicals were handled using a similar drum and wand system set on calibrated weigh scales. The mode of transport was by various pumps designed to have wetted parts compatible with the liquid they contacted. The SMT and the FHT have high-level alarms that are interlocked to the pumps feeding them (61-G-01 and 61-G-04) to prevent overfilling.

The SMT is a 500-gallon, $304 \mathrm{~L}$ jacketed stainless steel tank equipped with a Chemineer ${ }^{\circledR}$ agitator and internal heating and cooling coils. A schematic of the SMT is shown in Figure 5. The tank is vented by a separate off-gas system that filters the off-gas first before discharging it to the atmosphere via a 5 $\mathrm{hp}$ fan. It is capable of pushing $200 \mathrm{sfcm}$ of air. 
The SMT ventilation system $(61-\mathrm{V}-12)$ is skid-mounted and includes a filter and a slidegate damper to control air flow. The SMT fan (61-K-12) will maintain a slight vacuum on the SMT to aid in filling and keeping dust and nuisance vapors in the immediate area to a minimum. The feed preparation cycle is designed so that the only chemical reaction that will take place in this tank will be acid / base neutralization. Chilled water is run through the jacket to absorb the heat produced in the neutralization process.

Chemical additions to the SMT are made through liquid transfer, dry powder transfer, or portable nitric acid 55-gallon drum transfer lines. Chemical transfers out of the SMT to the FHT are transferred through a

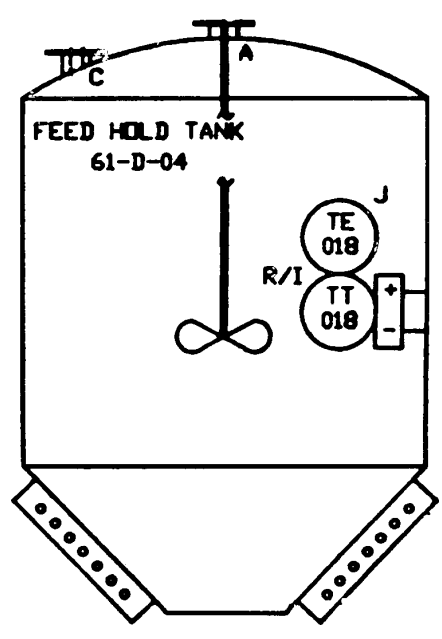

Figure 6. Feed Hold Tank Schematic grinder that maintains a maximum particle diameter of just under 50 microns.

Feed is transferred from the SMT to the FHT using Pump 61-G-01 after first going through the grinder (61-K-10).

The FHT is a 750 -gallon, $304 \mathrm{~L}$ semi-jacketed, stainless steel tank equipped with a Chemineer ${ }^{\circledR}$ agitator and internal heating and cooling coils. A schematic of the FHT is shown in Figure 6. The FHT is maintained under negative pressure controlled by the off-gas system. The off-gas system for the FHT is discussed in Section 3.5. This tank is utilized for boiling the waste simulant, mixing the waste simulant with the glass-formers, and the addition of sugar, to obtain the desired carbon-to-nitrate ratio. Once the water is essentially boiled away, the contents (i.e, slurry), after verification and approval by sample analysis, is transferred to the MFT.

\subsection{Melter Operations}

The MFT is a 75-gallon, $304 \mathrm{~L}$ stainless steel tank equipped with an agitator and a peristaltic pump. The peristaltic pump provides the melter feed to the melter at a constant flow rate through a water-cooled feed nozzle. The melter feed pump (61-G-06) has a variable frequency drive that gives it the ability to manually control the feed rate to the melter.

The SVS-III melter is capable of simulating the operations of the Vitrification Facility (VF) melter. It was built with $1 / 7$ th the surface area $\left(0.325 \mathrm{~m}^{2}, 18.25 " \mathrm{x} 28\right.$ ", with a maximum pool depth of 8.0") and 1/14th the volume (62 L maximum capacity) of the VF melter. This allows the SVS-III melter to reach steady state much faster and have a quicker volume changeout. A three-dimensional diagram of the SVS-III melter is shown in Figure 7.

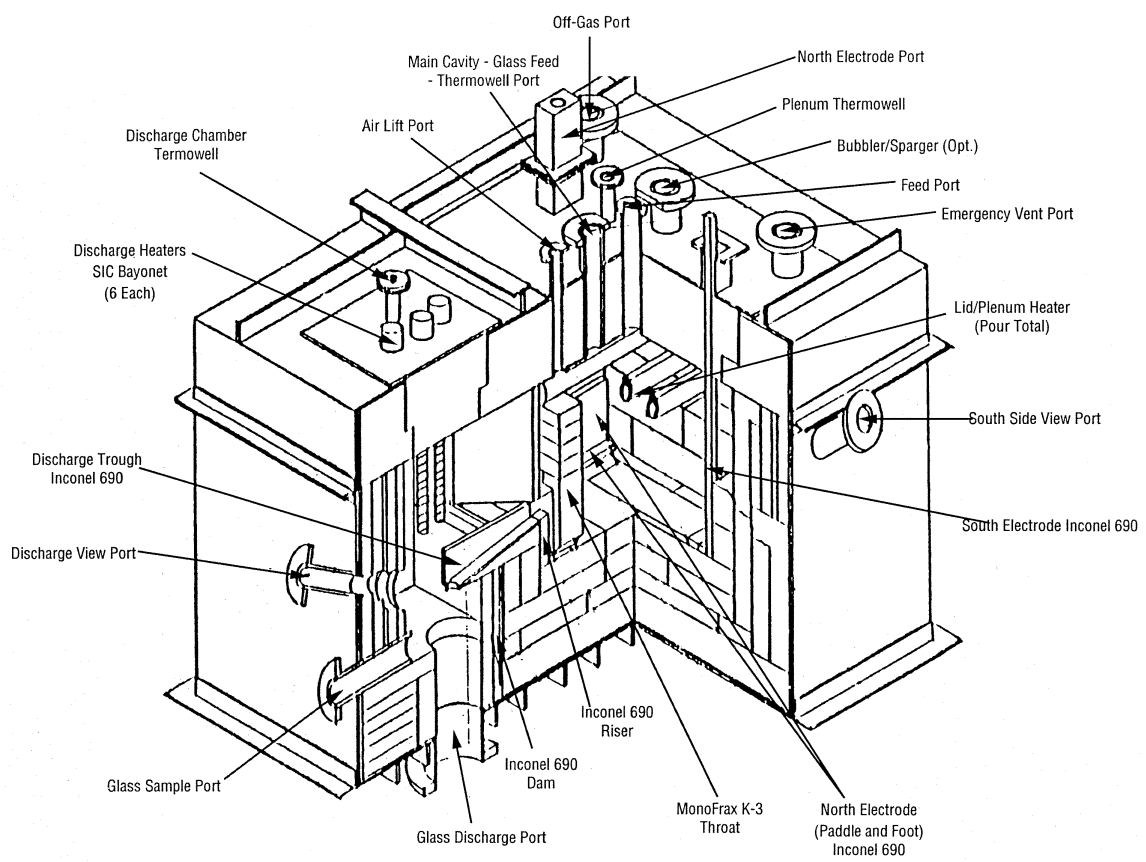

Figure 7. 3D Portrait of the SVS-III Melter 
The SVS-III melter is a simple rectangular geometry tank, straddled by two paddle-shaped Inconel ${ }^{\circledR}$ electrodes. A schematic of a single Inconel ${ }^{\circledR}$ electrode is shown in Figure 8. A single-phase selective catalytic reactor (SCR) and a transformer supply the electrodes that are controlled by a programmable controller, the Micristar ${ }^{\circledR} 828 \mathrm{D}$, by Research, Inc. This circuit is manually controlled for current.

Above the glass pool is a set of four plenum or lid heaters. These heaters are silicon carbide resistance heaters centrally located within the Inconel ${ }^{\circledR}$ sheaths. The plenum heaters are used during startup to raise the temperature of the glass surface until it becomes conductive enough for the electrodes to become productive. Once the glass is hot enough $\left(\sim 700^{\circ} \mathrm{C}\right)$, an electric current is passed through the electrodes. The resistance to the electric flow by the contents of the melter creates the heat required to melt the glass.

The heater assemblies enter the east vertical wall of the melter and can be serviced through an opening in the electrical protective housing around the terminal ends of

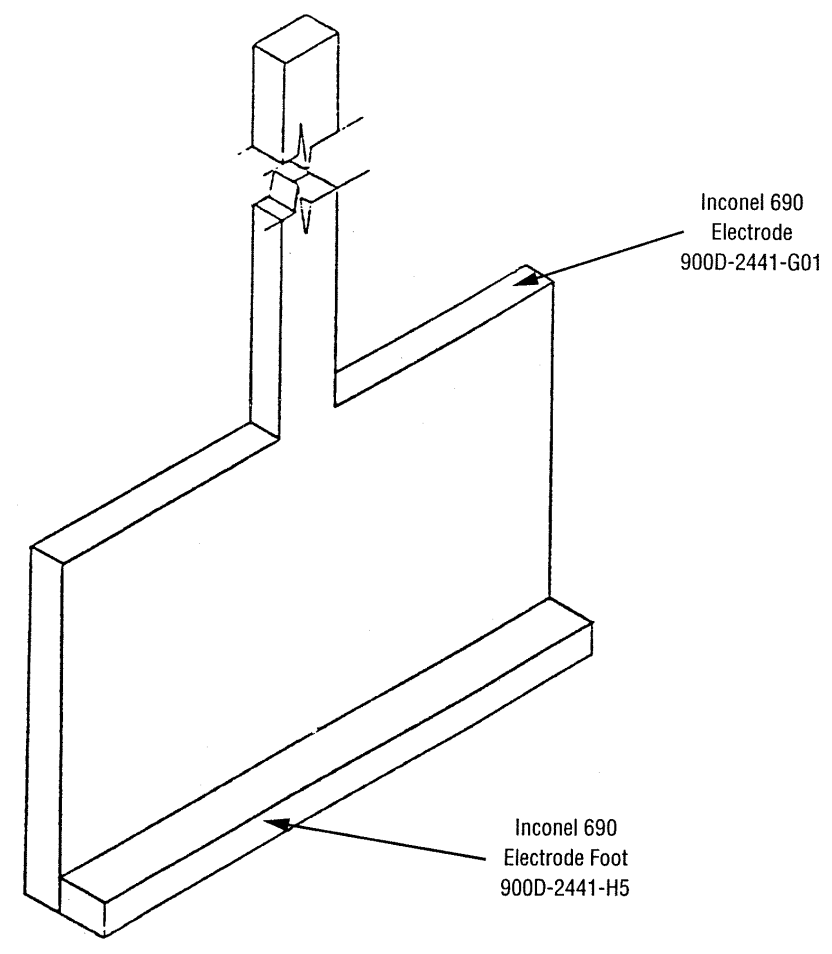

Figure 8. Inconel 690 Paddle Electrode Schematic the elements. Each heater is supplied by a single-phase SCR and a transformer (10 kW max). A single controller (2 control loops) governs all four SCRs. Two power supply units are supplied by one loop, the other two power supply units are controlled by the second loop. Thermocouples $(\mathrm{T} / \mathrm{C})$ located within the lid heater sheath provide temperature feedback for temperature control. (Note: Only one sheath T/C is controlling two heaters; the second sheath T/C is monitored, but not used as a control.) Figure 9 shows a schematic of the position of the discharge heaters, melter electrodes, and plenum heaters relative to the melter.

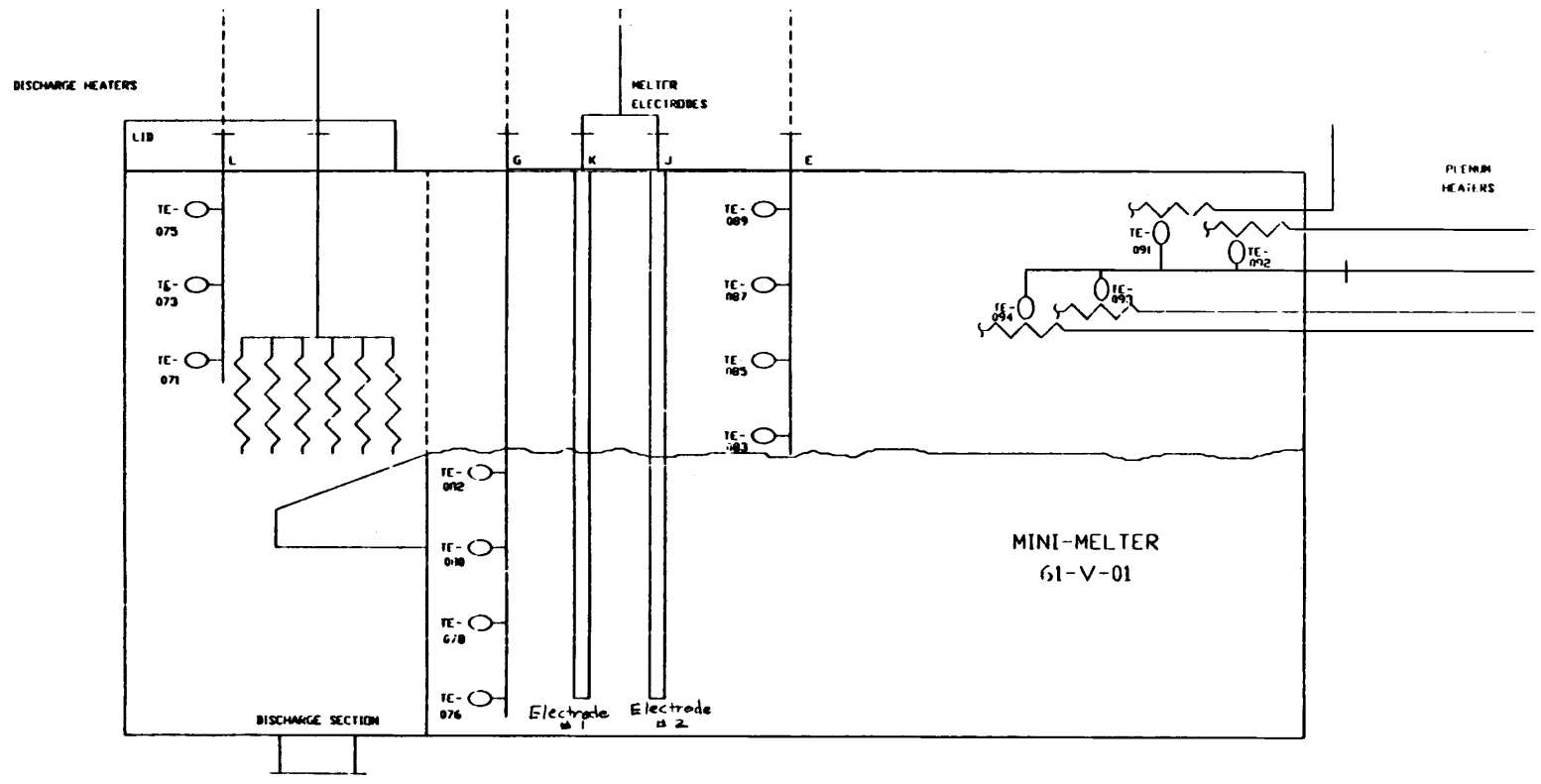

Figure 9. Discharge and Plenum Heaters and Melter Electrodes' Placement Schematic 
Glass is discharged from the melter through a single riser activated by an airlift lance. The glass flows down an Inconel ${ }^{\circledR}$ trough (as seen in Figure 7) and into a 30-gallon, stainless steel drum. Around the trough is a chamber heated by six silicon carbide elements. These heaters are fed from their own SCR and transformer and are controlled from a third, separate Micristar ${ }^{\circledR}$. A thermowell positioned in the discharge zone will contain feedback thermocouples for temperature control of the chamber.

The molten pool of glass is contained by Monofax ${ }^{\circledR} \mathrm{K}-3(\mathrm{Cr} / \mathrm{Al})$ refractory, backed by Zirmul $^{\circledR}$ (Al / Zr / Si type refractory), and $\mathrm{KaoTab}-95^{\circledR}\left(\mathrm{Al}_{2} \mathrm{O}_{3}\right.$ castable $)$. A single discharge orifice exits the melter cavity into the Inconel ${ }^{\circledR}$ 690 riser.

With lid heaters, a production rate of 4.5 to $12.0 \mathrm{~kg}$ of glass per hour can be expected.

Temperature of the melter is monitored in four primary areas: discharge chamber (Port-L), main pool (Port-D), plenum area (Port-E), and lid heater sheaths (local). A comprehensive melter lid port summary is given in Figure 10. All thermocouples $(\mathrm{T} / \mathrm{C})$ are fed to a patch panel at the control console. The control T/Cs are fed to the controller then jumpered at the patch panel. From the "lower

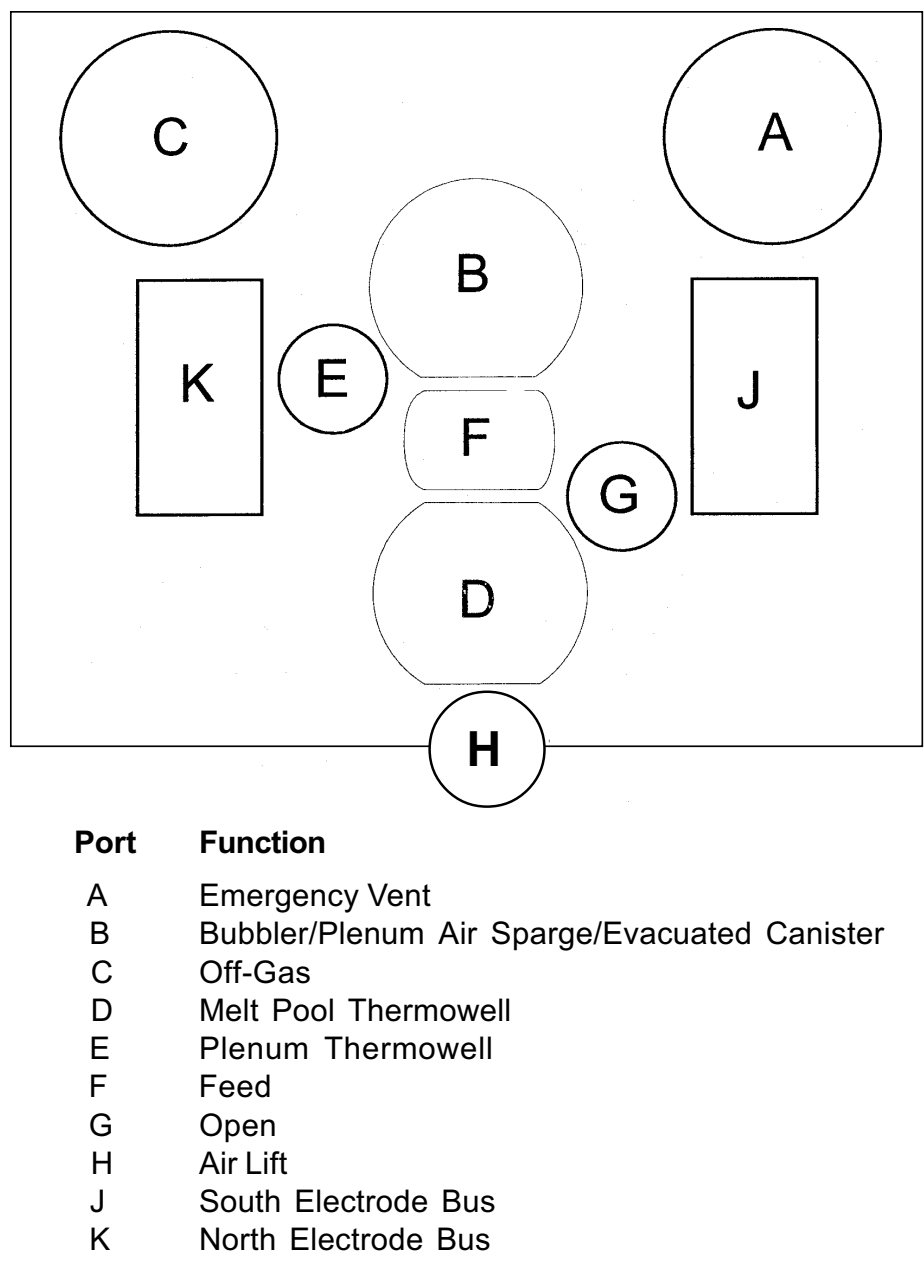

Figure 10. Melter Lid Port Configuration patch" strip, recording and monitoring can be accomplished by plugging a patch cord in from the desired location to an "upper patch" strip. The "upper patch" is hardwired to a strip chart recorder that monitors continuously during operation. The "lower patch" $\mathrm{T} / \mathrm{Cs}$ may be observed individually using a local channel selector and digital display.

A 30-gallon drum is mounted on the east end of a chain-driven conveyor $(63 \mathrm{C}-\mathrm{V}-02 \mathrm{~T})$ and conveyed westward under the melter discharge port. Permanent brackets line up the drum under a sealing bellows mounted to the discharge port. With a Fiberfrax ${ }^{\circledR}$ gasket around the perimeter of the drum lip, the sealing bellows can be extended to press firmly around the drum, sealing it to the discharge chamber. This is accomplished with a toggle clamp push rod and level actuator accessible from the north operating platform of the melter. The seal maintains the vacuum integrity of the melter. Glass will be discharged into the drum in increments of approximately 7 to $8 \mathrm{~L}$ each. This will require 11 to 12 airlift discharges to fill a drum, assuming 1 " melter inventory discharged per airlift.

The level of the drum will be monitored from the drum exterior using surface temperature indicators and an infrared (IR) pyrometer for backup. When full, the bellows is lifted from the drum and the drum is conveyed eastward. Once the drum is out of the way of the bellows, a plate cover can be slid under the bellows to curb heat loss and air inleakage. This plate sits on two angles straddling the bellows. 


\subsection{Off-gas Treatment System}

The off-gas treatment system provides a controlled negative-gauge pressure for the FHT, MFT, and melter. It will be operated in two distinct modes of operation depending on whether feed is being prepared or the melter is processing slurry. The equipment is sized so that it will not support simultaneous operation.

The volume of air flow will be constant for both modes. An air in-bleed in the melter off-gas line will be used to control the pressure in the melter and FHT while the off-gas treatment system is operating. A general off-gas treatment system flowsheet is shown in Figure 11.

Off-gas treatment is required to mitigate the effects of temperature, $\mathrm{NO}_{\mathrm{x}}$ formation, and particulate generation. A venturi scrubber with cyclonic separator (61-C-16) will quench the off-gas to remove large particulate matter. The off-gas will then be sent through the HEME to remove unwanted mist and particulates greater than submicron size before going to the SCR.

The water from the scrubber is collected in condensate hold tank (CHT) 61-D-08, cooled, and filtered before being reused in the scrubber. Excess accumulations of scrubber water are stored in scrubber water collection tank (SWCT) 61-D-07. This water is either used in the SMT during feed preparation activities or disposed of off site.

A skid-mounted off-gas blower (OGBS, 61-V-11) will provide the vacuum necessary to pull the vapors from their origin to the $\mathrm{NO}_{\mathrm{x}}$ reactor. The blower is a $10 \mathrm{hp}$, rotary, positive-displacement type made with stainless steel wetted parts. It was built for outdoor use and came equipped with silencers and flex connections.

The selective catalytic reduction process that is used in the SCR reduces $\mathrm{NO}_{\mathrm{x}}$ in the off-gas to nitrogen and water. The off-gas is first heated to $600^{\circ} \mathrm{C}$ using natural gas in a combustion chamber. $\mathrm{NH}_{3}$ is then added to the off-gas before the off-gas is passed through a fluidized bed of zeolite that has been treated with a catalyst. The effluent comes out the top of the SCR and enters the atmosphere from the stack.

The off-gas will be sampled for $\mathrm{NO}_{\mathrm{x}}$ concentration before and after the reactor in order to determine reactor efficiency and to control $\mathrm{NH}_{3}$ usage. The $\mathrm{NO}_{\mathrm{x}}$ analyzers are located in the off-gas Monitoring Room located east of the VTF. The control of the reactor and $\mathrm{NH}_{3}$ feed was integrated in the DCS located in the Vitrification Test Control Room (VTCR). There were local indicators to facilitate maintenance and troubleshooting. Slip samples of $\mathrm{NH}_{3}$ will be taken from the stack and sent to the gas chromatograph (GC) for analysis to confirm actual $\mathrm{NH}_{3}$ usage.

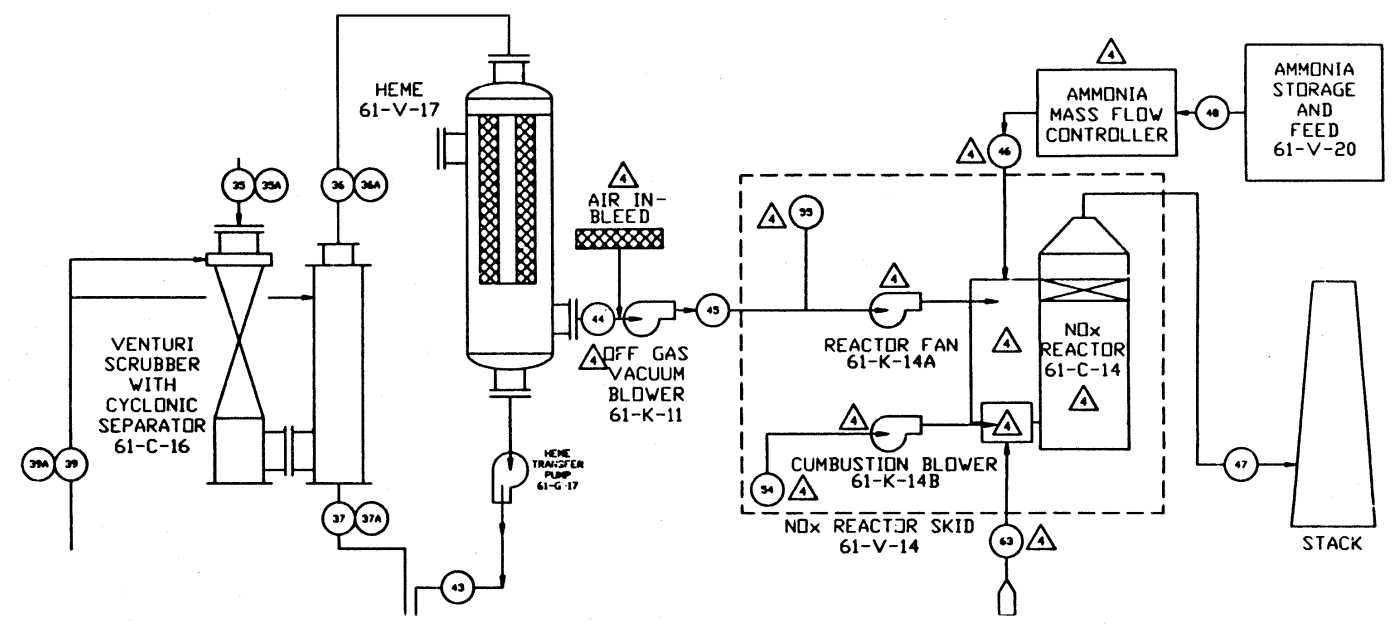

Figure 11. Off-gas Treatment System Flowchart 


\subsection{SVS-III TEST SERIES RATIONALE}

The three primary areas of interest during the SVS-III testing are the: redox state of the molten and solid glass, feed make-up strategy, and establishment of a statistical approach to the remote glass composition analysis by the Analytical and Process Chemistry (A\&PC) Lab.

\subsection{Redox}

The amount of oxygen available to the glass melt, as reflected in the ferrous / ferric $\left(\mathrm{Fe}^{+2} / \mathrm{Fe}^{+3}\right)$ or redox ratio, affects the melting process. Too much oxygen causes the melt to foam; at best slowing production, at worst plugging the off-gas system. Too little oxygen causes oxides like $\mathrm{Fe}_{2} \mathrm{O}_{3}, \mathrm{NiO}$, and $\mathrm{MnO}$ to convert into their metallic form and suspend themselves in the molten glass. Metal precipitate can then eventually build up to short out the electrodes, thus permanently damaging the melter.

During FACTS and prior SVS runs, an empirical relationship was developed between the redox ratio and the amount of sugar, nitrates, and total solids in the feed. The first series of experiments in SVS-III was designed to test that relationship and provide assurance that a similar relationship will hold for the melter during radioactive operations.

If it can be demonstrated that the redox ratio can be predicted from an analysis of the feed (i.e., sugar, nitrates, and total solids), then it will not be necessary to determine the redox ratio by converting feed into glass and analyzing for the $\mathrm{Fe}^{+2} / \mathrm{Fe}^{+3}$ ratio prior to feeding the melter. This will significantly reduce feed make-up cycle time.

\subsection{Feed Preparation Strategy}

There are various aspects of the feed preparation strategy that were investigated during SVS-III. These included the waste simulant concentration cycle, the use of antifoaming agents in glass-formers, when and where to add nitric acid, the addition of sodium metasilicate, and lab analysis of the feed materials. These activities center around the concentrator feed make-up tank (CFMT) during radioactive operations in the Vitrification Facility (VF).

A typical feed preparation for the SVS-III operation was comprised of several necessary steps for the production of an acceptable slurry feed for vitrification in the SVS-III melter. The main steps for the production of an acceptable slurry feed are shown in Table 2.

Waste simulant and glass-former batches are prepared by sequentially adding the chemicals listed in Tables 3 and 4. This ensures homogeneous preparation of batches and minimizes batch preparation cycle time.

The SVS-III tests are designed to look at the addition of simulated waste and other materials to the mixing tank. The order in which materials are added (i.e., simulated waste, glass-formers, antifoaming agents, nitric acid, etc.) affects the process. Upsets to this process can cause rejection of the batch in the VF (returning the batch to Tank $8 \mathrm{D}-2$ ) or contamination of downstream equipment. 
Table 2: Slurry Feed Production Steps

$\begin{array}{ll}\text { Step \# } & \text { Description } \\ 1 & \text { Addition of chemicals to the SMT to make up the waste simulant (see Table 3) } \\ 2 & \text { Transfer of waste simulant from the SMT to the FHT } \\ 3 & \text { Pull process control samples of the contents of the FHT (waste simulant) } \\ 4 & \text { Boiling down the contents in the FHT to remove excess water } \\ 5 & \text { Pull process control samples of the FHT (waste simulant) after the boil down } \\ 6 & \text { Addition of chemicals to the SMT (see Table 4) to make up the glass-formers } \\ 7 & \text { Pull process samples of the SMT (glass-formers) } \\ 8 & \text { Lower the FHT temperature to } \sim 25^{\circ} \mathrm{C} \text { for the addition of the contents of the SMT to the FHT } \\ 9 & \text { Pull process samples of the FHT (slurry) }\end{array}$

If shimming is necessary, proceed with steps 10 and 11 prior to the addition of sugar. If shimming is unnecessary, then proceed directly to step 12 (sugar addition).

10 Boil down the FHT contents again

11 Pull process control samples of the FHT after second boil down

12 Addition of sugar to the FHT is based on analysis of the slurry samples pulled during steps 9 or 11

13 Transfer of contents from the FHT to the MFT on a batch basis

Sampling is a critical operation. Because chemical analysis of the feed slurry provides assurance in producing the target glass composition, the sampling process must provide a representative sample of the material being fed to the melter. It is known that foaming of the slurry and the sampling system greatly affect the ability to take a representative sample. Resolving these problems with the taking and analyzing of representative samples was one of the goals of SVS-III.

\subsection{Analytical Chemistry}

As alluded to at the end of Section 4.2, the chemical analysis of the feed slurry is a critical step in the process control strategy. In addition to the above challenges, it must be determined how many samples are necessary for the A\&PC Lab to analyze in order to provide assurance that the glass composition will be within the parameters defined by the Waste Acceptance Product Specifications (WAPS). It is estimated that nine samples of slurry will be necessary to provide statistical surety that the glass is within specifications. The SVS-III runs will be testing that estimate. The results will provide the assurance that the methods are acceptable for radioactive operations. 
Table 3: Typical Sequence of Addition for Waste Simulant

\begin{tabular}{clcclc}
$\begin{array}{c}\text { Sequence } \\
\text { Added }\end{array}$ & Chemical & $\begin{array}{c}\text { Target } \\
\text { Amount (kg) }\end{array}$ & $\begin{array}{c}\text { Sequence } \\
\text { Added }\end{array}$ & \multicolumn{1}{c}{ Chemical } & $\begin{array}{c}\text { Target } \\
\text { Amount (kg) }\end{array}$ \\
\hline 1 & Ferric Hydroxide & 844.82 & 17 & Sodium Molybdate & 0.42 \\
2 & Boron Oxide & 0.44 & 18 & Strontium Hydroxide & 0.18 \\
3 & Barium Hydroxide & 2.45 & 19 & Titanium Dioxide & 0.81 \\
4 & Cerium Hydroxide & 2.86 & 20 & Silicon Dioxide & 22.84 \\
5 & Cesium Hydroxide & 0.69 & 21 & Aluminum Hydroxide & 10.62 \\
6 & Copper Hydroxide & 0.46 & 22 & Calcium Carbonate & 3.91 \\
7 & Lanthanum Oxide & 0.30 & 23 & Potassium Hydroxide & 39.16 \\
8 & Magnesium Hydroxide & 0.48 & 24 & Sodium Hydroxide & 7.36 \\
9 & Manganese Dioxide & 5.13 & 25 & Monosodium Phosphate & 14.74 \\
10 & Neodymium Oxide & 1.36 & 26 & Sodium Nitrate & 16.78 \\
11 & Nickel Hydroxide & 2.25 & 27 & Sodium Nitrite & 25.92 \\
12 & Palladium Oxide & 0.22 & 28 & Zirconyl Nitrate $(42.5 \%)$ & \\
& & & & Solution & 78.27 \\
13 & Rhodium Oxide & 0.14 & 29 & Zeolite IE-96 & 68.15 \\
14 & Ruthenium Oxide & 0.58 & 30 & Zeolite TIE-96 & 37.88 \\
15 & Sodium Sulfate & 2.97 & 31 & Sodium Metasilicate & 2.52 \\
16 & Zinc Oxide & 0.15 & & &
\end{tabular}

\subsection{Rationale Summary}

With the overall goals of the Project and how they lead to useful information for radioactive operations, it should be remembered that these are experimental runs. The details of each of the following experiments are critical to the interpretation of the results. The logs kept by the operators and supervisors will contain many clues that may help decipher otherwise unintelligible results.

Table 4: Typical Sequence of Addition for Glass-Formers

\begin{tabular}{|c|c|c|c|c|c|c|c|}
\hline $\begin{array}{l}\text { Sequence } \\
\text { Added }\end{array}$ & Chemical & $\begin{array}{c}\text { Target } \\
\text { Amount } \\
\text { (kg) }\end{array}$ & $\begin{array}{c}\text { Actual } \\
\text { Amount } \\
(\mathbf{k g})\end{array}$ & $\begin{array}{c}\text { Sequence } \\
\text { Added }\end{array}$ & Chemical & $\begin{array}{c}\text { Target } \\
\text { Amount } \\
\text { (kg) }\end{array}$ & $\begin{array}{c}\text { Actual } \\
\text { Amount } \\
\text { (kg) }\end{array}$ \\
\hline 1 & Nitric Acid (35\%) & 680.14 & 680.20 & 10 & Magnesium Hydroxide & 7.63 & 7.65 \\
\hline 2 & $\begin{array}{l}\text { Zirconyl Nitrate } \\
\text { Solution }\end{array}$ & 47.41 & 47.4 & 11 & Sodium Tetraborate & 37.00 & 37.00 \\
\hline 3 & Potassium Hydroxide & 9.12 & 9.12 & 12 & Silicon Dioxide & 68.15 & 68.15 \\
\hline 4 & Lithium Hydroxide & 75.11 & 75.1 & 13 & Maganese Dioxide & 2.25 & 2.25 \\
\hline 5 & Monosodium Phosphate & 0.00 & 0.00 & 14 & Titanium Dioxide & 2.91 & 2.90 \\
\hline 6 & Boron Oxide & 44.33 & 44.33 & 15 & Silicon Dioxide & 90.86 & 90.95 \\
\hline 7 & Sodium Tetraborate & 37.00 & 37.00 & 16 & Sodium Tetraborate & 49.33 & 49.34 \\
\hline 8 & Silicon Dioxide & 68.15 & 68.15 & 17 & $\begin{array}{l}\text { P-1200 }{ }^{\circledR} \text { Antifoam } \\
\text { (liquid) }\end{array}$ & 5.04 & 5.05 \\
\hline 9 & Aluminum Hydroxide & 31.83 & 31.83 & & & & \\
\hline
\end{tabular}




\subsection{SVS-III TEST SERIES DATA ANALYSIS}

\subsection{Introduction}

The SVS-III test series was conducted with a focus on confirming the applicability of the Redox Forecasting Model, based on the Index of Feed Oxidation (IFO), developed during the FACTS and SVS-I tests. An additional goal was to investigate the relationship between melter parameters (i.e., feed rate, plenum temperature, cold cap coverage, glass redox state, internal pool temperature, and melter power) and melter operation.

In the SVS-III test series, the feed slurry recipe, based on the Reference 6 glass composition, was formulated to produce $720 \mathrm{~kg}$ of glass per batch. The target ferrous-to-ferric ratio in the glass product was varied from run to run by adjusting the amount of reductant (sugar) to be added to the slurry. The aim was to produce glass with $\mathrm{Fe}^{+2} / \mathrm{Fe}^{+3}$ ratios covering the range from 0.01 (oxidized) to $<1.0$ (reduced). Heel simulation was not included in the feed preparation cycle.

A typical feed preparation cycle extended over four to five days. It proceeded from chemical staging to the mixing of chemicals for the waste simulant and glass-former, then continued with combining simulant and glass-former, and lastly adding sugar. The feed recipe was unchanged throughout the test series, with the exception that the amounts of nitrate and sugar were adjusted to target different redox states. Samples for analysis were taken at several points during the feed preparation cycle in order to characterize the slurry, confirm the composition, and calculate the reductant addition. Tank levels and slurry densities were measured at each sampling point with a level probe. Slurry characterization and compositional analysis were performed by the Vitrification Lab and the A\&PC Lab.

For each feed batch, specific gravity was measured for pre-boil simulant, post-boil simulant, glass-former, pre-sugar slurry, and post-sugar slurry; $\mathrm{pH}$ was measured for glass-former and post-sugar slurry. Post-boil simulant, glass-former, pre-sugar slurry, and post-sugar slurry were analyzed for total nitrates. Post-boil simulant was analyzed for total nitrites. Total carbon was measured in the post-sugar slurry and the percent total solids (\% TS) was measured in the glass-formers and post-sugar slurry. Compositional analysis by inductively coupled plasma (ICP) was carried out by the A\&PC Lab on the waste simulant, glass-former, and final slurry mixtures.

\subsection{Feed Preparation}

In the SVS-III test series, raw material calculations for the melter feed targeted an 1,800 L slurry batch to produce $720 \mathrm{~kg}$ of glass. In the feed preparation cycle, waste simulant chemicals $(\sim 1,100 \mathrm{~L})$ were mixed first in the slurry mix tank (SMT) then transferred to the feed hold tank (FHT) and boiled down to about 900 L. After the waste simulant was transferred to the FHT, the glass-former chemicals $(\sim 900 \mathrm{~L})$ were mixed in the SMT and then combined with the boiled-down simulant in the FHT. The slurry was then analyzed for total nitrates. The sugar addition was calculated based on the total nitrates and the results of the Vitrification Lab crucible melt tests. The slurry was then analyzed again after the sugar addition, shimmed if necessary, then transferred in small batches to the melter feed tank (MFT) as the feed was delivered to the melter. 


\subsubsection{Feed Recipe}

Nominal waste simulant and glass-former recipes for the SVS-III test series are shown in Table 5. The same feed recipe was used for all of the test runs in the series except for Runs 1-01 and 1-01A, which were higher in $\mathrm{Al}(\mathrm{OH})_{3}, \mathrm{Fe}(\mathrm{OH})_{3}$, and nitric acid. The batches were prepared by sequentially adding chemicals as shown in Tables 3 and 4.

Table 5: Target Glass Composition for SVS-III Testing (wt \%)

\begin{tabular}{|c|c|c|c|}
\hline Oxide & Ref 6 & Waste Simulant & Glass Former \\
\hline $\mathrm{Al}_{2} \mathrm{O}_{3}$ & 6.00 & 3.11 & 2.89 \\
\hline $\mathrm{B}_{2} \mathrm{O}_{3}$ & 12.89 & 0.06 & 12.83 \\
\hline $\mathrm{BaO}$ & 0.16 & 0.16 & --- \\
\hline $\mathrm{CaO}$ & 0.48 & 0.48 & --- \\
\hline $\mathrm{Ce}_{2} \mathrm{O}_{3}$ & 0.31 & 0.31 & --- \\
\hline $\mathrm{Cr}_{2} \mathrm{O}_{3}$ & 0.14 & 0.14 & --- \\
\hline $\mathrm{Cs}_{2} \mathrm{O}$ & 0.08 & 0.08 & --- \\
\hline $\mathrm{CuO}$ & 0.05 & 0.05 & --- \\
\hline $\mathrm{Fe}_{2} \mathrm{O}_{3}$ & 12.02 & 12.02 & --- \\
\hline $\mathrm{K}_{2} \mathrm{O}$ & 5.00 & 4.07 & 0.93 \\
\hline $\mathrm{La}_{2} \mathrm{O}_{3}$ & 0.04 & 0.04 & --- \\
\hline $\mathrm{Li}_{2} \mathrm{O}$ & 3.71 & --- & 3.71 \\
\hline $\mathrm{MgO}$ & 0.89 & 0.18 & 0.71 \\
\hline $\mathrm{MnO}$ & 0.82 & 0.57 & 0.25 \\
\hline $\mathrm{MoO}_{3}$ & 0.04 & 0.04 & --- \\
\hline $\mathrm{Na}_{2} \mathrm{O}$ & 8.00 & 5.00 & 3.00 \\
\hline $\mathrm{Nd}_{2} \mathrm{O}_{3}$ & 0.18 & 0.18 & --- \\
\hline $\mathrm{NiO}$ & 0.25 & 0.25 & --- \\
\hline $\mathrm{P}_{2} \mathrm{O}_{5}$ & 1.20 & 1.20 & --- \\
\hline $\mathrm{PdO}$ & 0.03 & 0.03 & --- \\
\hline $\mathrm{Rh}_{2} \mathrm{O}_{3}$ & 0.02 & 0.02 & --- \\
\hline $\mathrm{RuO}_{2}$ & 0.08 & 0.08 & --- \\
\hline $\mathrm{SO}_{3}$ & 0.23 & 0.23 & --- \\
\hline $\mathrm{SiO}_{2}$ & 43.07 & 11.52 & 31.55 \\
\hline $\mathrm{SrO}$ & 0.02 & 0.02 & --- \\
\hline $\mathrm{TiO}_{2}$ & 0.80 & 0.40 & 0.40 \\
\hline $\mathrm{Y}_{2} \mathrm{O}_{3}$ & 0.05 & 0.05 & --- \\
\hline $\mathrm{ZnO}$ & 0.02 & 0.02 & --- \\
\hline $\mathrm{ZrO}_{2}$ & 3.42 & 2.13 & 1.29 \\
\hline Totals & 100.0 & 42.44 & 57.56 \\
\hline
\end{tabular}

\subsubsection{Feed Preparation Cycle}

In a typical feed preparation cycle, the waste simulant chemicals were first added to the SMT to a volume of $\sim 1,100 \mathrm{~L}$ (density of $\sim 1.1 \mathrm{~kg} / \mathrm{L}$ ). The waste simulant was then transferred to the FHT and boiled down to $\sim 900 \mathrm{~L}$ (density of $\sim 1.3 \mathrm{~kg} / \mathrm{L}$ ). Glass-former chemicals were then mixed in the SMT and combined with the post-boil waste simulant in the FHT. The glass-former volume was typically $\sim 900 \mathrm{~L}$ (density of $\sim 1.4 \mathrm{~kg} / \mathrm{L}$ ). The target feed volume was $\sim 1,800 \mathrm{~L}$. 


\subsection{2 $\mathrm{NO}_{\mathrm{x}}$ Generation}

As the glass-formers are transferred from the SMT and added to the concentrated waste simulant in the FHT, the $\mathrm{HNO}_{3}$ in the glass-formers reacts with the $\mathrm{NaNO}_{2}$ in the waste simulant to generate $\mathrm{NO}_{\mathrm{x}}$ according to the reactions shown below:

$$
\begin{aligned}
& \mathrm{NaNO}_{2}+\mathrm{HNO}_{3} \rightarrow \mathrm{NaNO}_{3}+\mathrm{HNO}_{2} \\
& 3 \mathrm{HNO}_{2} \rightarrow \mathrm{H}^{+}+\mathrm{NO}_{3}^{-}+2 \mathrm{NO}+\mathrm{H}_{2} \mathrm{O}
\end{aligned}
$$

During SVS-III testing, $\mathrm{NO}_{\mathrm{x}}$ emissions accompanying the glass-former transfer ranged from $\sim 0.3 \mathrm{~kg}$ (Run 1-04) to $\sim 3 \mathrm{~kg}$ (Run 1-03). It was found that this nitrate loss could be minimized by cooling the simulant after boil-down to less than $30^{\circ} \mathrm{C}$ before adding the glass-former and by reducing the temperature differential between the glass-former and the waste simulant in the FHT.

\subsubsection{Reductant Addition}

The amount of sugar to be added to the feed as a reductant was determined by the amount of nitrates and the total organic carbon in the slurry as analyzed by the A\&PC Lab and by the Vitrification Lab Direct Slurry Redox Testing (DSRT) of crucible melts with different amounts of sugars added. In a typical redox test, a 30 $\pm 5 \mathrm{~mL}$ of slurry in a closed quartz crucible is vitrified at $1,150^{\circ} \mathrm{C}$ for one hour. After one hour of melting, the crucible is removed from the furnace, cooled, and the glass is analyzed for the $\mathrm{Fe}^{+2} / \mathrm{Fe}^{+3}$ ratio. From these data, a target IFO was selected to produce glass with the desired redox characteristics. The IFO formula is:

$$
\mathrm{IFO}=\mathrm{NO} 3(1-\mathrm{TS}) / \mathrm{TOC}
$$

where $\mathrm{NO}_{3}=$ nitrate concentration, TS $=$ fraction of total solids, and TOC $=$ amount of total organic carbon.

Table 6 shows the target IFO, analyzed IFO, target $\mathrm{Fe}^{+2} / \mathrm{Fe}^{+3}$ ratio, steady state $\mathrm{Fe}^{+2} / \mathrm{Fe}^{+3}$ ratio, and TOC for the eight test runs comprising the SVS-III test series. The target IFO values were used to calculate the amount of sugar needed based on the analyzed nitrate and TOC amounts. A 50\% TS was assumed in all cases. Analyzed IFO values were calculated from A\&PC Lab analyses for total solids, total carbon, and nitrates (with a correction added for nitrates from zirconyl nitrate), and the post-sugar tank volumes.

\begin{tabular}{lccccc} 
& \multicolumn{2}{c}{ Table 6: Test Series Redox Targets } \\
Test Run & Target IFO & Analyzed IFO & $\begin{array}{c}\text { Target } \\
\mathbf{F e}^{+2} / \mathbf{F e}^{+\mathbf{3}}\end{array}$ & $\begin{array}{c}\text { Steady State } \\
\mathbf{F e}^{+2} / \mathbf{F e}^{+3}\end{array}$ & $\begin{array}{c}\text { Analyzed TOC } \\
\text { (ppm) }\end{array}$ \\
$1-01$ & & & $0.2^{*}$ & 0.02 & 25,500 \\
$1-01 \mathrm{~A}$ & 2.43 & 2.69 & $0.2^{*}$ & 0.02 & 25,250 \\
$1-03$ & 2.43 & 2.45 & $0.1^{*}$ & 0.02 & 24,027 \\
$1-03$, II & 2.55 & 2.51 & $0.1^{*}$ & $0.08 \#$ & 24,776 \\
$1-04$ & 2.53 & 2.42 & $0.2^{*}$ & $0.56 \#$ & 26,996 \\
$1-04$ & 2.11 & 2.17 & $0.8^{* *}$ & 0.74 & 25,225 \\
$1-05$ & 2.26 & 2.54 & $0.4^{* *}$ & 0.54 & 26,992 \\
$1-06$ & 2.34 & 2.40 & $0.2^{* *}$ & 0.03 & 26,922 \\
$2-01$ & 2.28 & 2.38 & $0.01^{* *}$ & 0.01 & 22,500 \\
$2-02$ & 3.08 & 2.74 & $<0.01^{* *}$ & $<0.01$ & 22,500 \\
\hline
\end{tabular}

* Based on IFO model developed from FACTS and SVS-1 testing.

** Based on IFO model as being developed using SVS-III.

\# Estimated steady state $\mathrm{Fe}^{+2} / \mathrm{Fe}^{-3}$ ratio. 
A typical nitrate balance for the SVS-III test series (i.e., Runs 1-05 and 1-06) is shown in Table 7. Sodium nitrite and sodium nitrate solutions were added to the SVS-III slurry recipe to more closely simulate the waste tank composition. This represents a departure from the recipes used in the FACTS and SVS-I test series.

Throughout the SVS-III test series, the amount of total nitrates reported by A\&PC Lab analysis was lower than the amount calculated from the additions made for the particular test run. Investigation into possible causes of this shortfall revealed that not all of the nitrates contributed by zirconyl nitrate in both the waste simulant and glass-former can be detected by chemical analysis since the compound is polymeric and does not completely dissociate.

Upon heating, however, the zirconyl nitrate does decompose releasing nitrates and so must be included in the tally. By calculations made from the target $\mathrm{NO}_{3}$ values and chemical additions, the amount of $\mathrm{NO}_{3}$ in the final slurry contributed by zirconyl nitrate was found to be $\sim 25 \mathrm{~kg}$ in a typical SVS-III slurry batch. Adding this value to the analyzed total $\mathrm{NO}_{3}$ brings the analyzed $\mathrm{NO}_{3}$ amount to within the measurement uncertainty range of the target for the total nitrates. Calculations to determine the amount of reductant (sugar) to add to the slurry have been modified to account for this difference.

Table 7: Typical Nitrate Balance in a SVS-III Slurry

\begin{tabular}{|c|c|c|c|c|c|c|}
\hline \multirow[t]{2}{*}{ Source } & \multicolumn{2}{|c|}{ Simulant (kg) } & \multicolumn{2}{|c|}{ Glass-Former (kg) } & \multicolumn{2}{|c|}{ Slurry (kg) } \\
\hline & $\begin{array}{c}\text { Amount } \\
\text { Added }\end{array}$ & $\begin{array}{c}\text { Amount } \\
\mathrm{NO}_{3}\end{array}$ & $\begin{array}{c}\text { Amount } \\
\text { Added }\end{array}$ & $\begin{array}{c}\text { Amount } \\
\mathrm{NO}_{3}\end{array}$ & $\begin{array}{c}\text { Amount } \\
\text { Added }\end{array}$ & $\begin{array}{c}\text { Amount } \\
\mathrm{NO}_{3}\end{array}$ \\
\hline Nitric Acid & 0.00 & 0.00 & 680.10 & 234.26 & 680.10 & 234.26 \\
\hline Sodium Nitrate & 16.78 & 12.24 & 0.00 & 0.00 & 16.78 & 12.24 \\
\hline Sodium Nitrite & 25.92 & 7.75 & 0.00 & 0.00 & 25.92 & $7.75^{*}$ \\
\hline Zirconyl Nitrate & 78.28 & 31.69 & 47.40 & 19.19 & 125.68 & 50.88 \\
\hline Total $\mathrm{NO}_{3}$ & & 51.68 & & 253.45 & & 305.13 \\
\hline Total $\mathrm{NO}_{2}$ & & & & & & 17.28 \\
\hline
\end{tabular}

*includes $\mathrm{NaNO}_{2}$ converted to $\mathrm{NO}_{3}$ per reactions (1) and (2) of Section 5.2.2.

The target oxide composition for a $720 \mathrm{~kg}$ batch of the SVS-III slurry is shown in Table 8. For all eight test runs in the SVS-III test series, the target oxide composition, based on the Reference 6 waste glass, remained the same. For each batch, ICP analysis was performed by the A\&PC Lab on the waste simulant, glass-former, and final slurries in order to compare the batch compositions with the target. Agreement between analyzed compositions of the glass-former and final slurries and their targets was generally good.

Properties of the slurries (post-sugar) prepared during SVS-III Run 1-06 are summarized in Table 9. Following Run 1-01, the nitric acid addition was reduced in order to shift the $\mathrm{pH}$ of the slurry into a less acidic range. A target total nitrates value of $\sim 305 \mathrm{~kg}$ for an 1,800 L slurry batch was used in all subsequent test runs except Run 1-04. In Run 1-04, the target $\mathrm{NO}_{3}$ value was lowered in order to facilitate reduction of the glass melt. In SVS-III series test runs, the amount of total organic carbon was varied to target different ferrous-to-ferric ratios in the glass product.

\subsection{Melter Operation}

During melter operation, the plenum temperature, feed rate, cold cap coverage, melter power, internal glass pool temperature, and ferrous-to-ferric ratio were monitored throughout each run to establish and maintain steady state operation. 
Table 8: Target Oxide Composition of a Slurry

\begin{tabular}{|c|c|c|c|}
\hline Oxide & Simulant Target (kg) & Glass-Former Target (kg) & Final Slurry Target (kg) \\
\hline $\mathrm{Al}_{2} \mathrm{O}_{3}$ & 22.39 & 20.81 & 43.20 \\
\hline $\mathrm{B}_{2} \mathrm{O}_{3}$ & 0.43 & 92.38 & 92.81 \\
\hline $\mathrm{BaO}$ & 1.15 & --- & 1.15 \\
\hline $\mathrm{CaO}$ & 3.46 & --- & 3.46 \\
\hline $\mathrm{Ce}_{2} \mathrm{O}_{3}$ & 2.23 & --- & 2.23 \\
\hline $\mathrm{Cs}_{2} \mathrm{O}$ & 0.58 & --- & 0.58 \\
\hline $\mathrm{CuO}$ & 0.36 & --- & 0.22 \\
\hline $\mathrm{Fe}_{2} \mathrm{O}_{3}$ & 86.54 & --- & 86.54 \\
\hline $\mathrm{K}_{2} \mathrm{O}$ & 29.30 & 6.70 & 36.00 \\
\hline $\mathrm{La}_{2} \mathrm{O}_{3}$ & 0.29 & --- & 0.29 \\
\hline $\mathrm{Li}_{2} \mathrm{O}$ & --- & 26.71 & 26.71 \\
\hline $\mathrm{MgO}$ & 1.30 & 5.11 & 6.41 \\
\hline $\mathrm{MnO}$ & 4.10 & 1.80 & 5.90 \\
\hline $\mathrm{MoO}_{3}$ & 0.29 & --- & 0.29 \\
\hline $\mathrm{Na}_{2} \mathrm{O}$ & 36.00 & 21.60 & 57.60 \\
\hline $\mathrm{Nd}_{2} \mathrm{O}_{3}$ & 1.30 & --- & 1.01 \\
\hline $\mathrm{NiO}$ & 1.80 & --- & 1.80 \\
\hline $\mathrm{P}_{2} \mathrm{O}_{5}$ & 8.64 & --- & 8.64 \\
\hline $\mathrm{PdO}$ & 0.22 & --- & 0.22 \\
\hline $\mathrm{Rh}_{2} \mathrm{O}_{3}$ & 0.14 & --- & 0.14 \\
\hline $\mathrm{RuO}_{2}$ & 0.58 & --- & 0.58 \\
\hline $\mathrm{SO}_{3}$ & 1.66 & -- & 1.66 \\
\hline $\mathrm{SiO}_{2}$ & 82.94 & 227.16 & 310.68 \\
\hline $\mathrm{SrO}$ & 0.14 & -- & 0.14 \\
\hline $\mathrm{TiO}_{2}$ & 2.88 & 2.88 & 5.76 \\
\hline $\mathrm{ZnO}$ & 0.14 & -- & 0.14 \\
\hline $\mathrm{ZrO}_{2}$ & 15.34 & 15.3 & 24.70 \\
\hline Totals & 304.20 & 414.44 & 718.86 \\
\hline
\end{tabular}


Table 9: Properties of Post-Sugar Slurries

\begin{tabular}{|c|c|c|c|c|c|c|c|c|}
\hline Test Run & $\begin{array}{l}\text { IFO } \\
\text { (meas.) }\end{array}$ & pH & $\begin{array}{l}\text { Density } \\
(\mathrm{kg} / \mathrm{L})\end{array}$ & $\begin{array}{l}\text { Vol. } \\
\text { (l) }\end{array}$ & $\begin{array}{l}\mathrm{NO}_{3} \\
(\mathrm{~kg})\end{array}$ & $\begin{array}{l}\text { TOC } \\
\text { (kg) }\end{array}$ & $\%$ TS & $\begin{array}{l}\text { Oxide Load } \\
\text { (g/L) }\end{array}$ \\
\hline T1-01 & 2.69 & 1.15 & 1.36 & 2,147 & $\begin{array}{l}375.5 \\
+24.8^{*}\end{array}$ & 74.4 & 50.0 & -- \\
\hline T1-01A & 2.45 & 4.40 & 1.36 & 1,373 & $\begin{array}{l}201.6 \\
+18.9^{*}\end{array}$ & 47.1 & 47.6 & -- \\
\hline T1-03 & 2.51 & 2.80 & 1.35 & 1,859 & $\begin{array}{l}276.1 \\
+24.8^{*}\end{array}$ & 60.3 & 49.1 & 378.8 \\
\hline T1-03II & 2.42 & --- & 1.35 & 525 & $\begin{array}{l}88.9 \\
+7.2^{*}\end{array}$ & 17.6 & 49.0 & --- \\
\hline T1-04 & 2.17 & 4.10 & 1.33 & 1,983 & $\begin{array}{l}273.0 \\
+24.8^{*}\end{array}$ & 71.2 & 48.0 & 359.1 \\
\hline T1-04' & 2.54 & 1.83 & 1.32 & 1,630 & $\begin{array}{l}225.3 \\
+22.4^{*}\end{array}$ & 54.3 & 44.3 & -- \\
\hline T1-05 & 2.40 & 3.59 & 1.37 & 1,803 & $\begin{array}{l}289.0 \\
+24.8^{*}\end{array}$ & 66.7 & 49.0 & 396.6 \\
\hline T1-06 & 2.38 & 3.30 & 1.33 & 1,779 & $\begin{array}{l}261.7 \\
+24.8^{*}\end{array}$ & 63.7 & 47.1 & 372.4 \\
\hline T2-01 & 2.74 & 3.67 & 1.37 & 1,785 & $\begin{array}{l}283.7 \\
+24.8^{*}\end{array}$ & 55.0 & 51.1 & 410.8 \\
\hline
\end{tabular}

* $\mathrm{NO}_{3}$ from zirconyl nitrate (not measurable in lab analysis)

\subsubsection{Feed Rate, Cold Cap, Plenum and Internal Glass Temperature, and Melter Power}

The feed rate, cold cap coverage, and plenum temperature are interdependent. At the beginning of a melter run, the feed rate is high to establish a cold cap over the glass melt. Once a cold cap is established, the feed rate is reduced into the target range of 15 to $20 \mathrm{~L} / \mathrm{hr}$. The extent of the cold cap coverage determines the plenum temperature, with $\sim 85 \%$ coverage maintaining a plenum temperature in the target range of 500 to $600^{\circ} \mathrm{C}$.

Summary plots of average feed rate and average plenum temperature for the SVS-III series test runs are shown in Figures 12 and 13, respectively. The feed rate was generally initiated at 25 to $30 \mathrm{~L} / \mathrm{hr}$, decreased to average in the target range within the first ten hours, and maintained at a steady rate throughout the remainder of the operating time with brief interruptions to clear the feed line, airlift glass, or change the canisters. The plenum temperature typically decreased from $900^{\circ} \mathrm{C}$ to $\sim 600^{\circ} \mathrm{C}$ during the first five hours of a run, then stabilized around 500 to $600^{\circ} \mathrm{C}$, remaining in this range until the end of the run. 


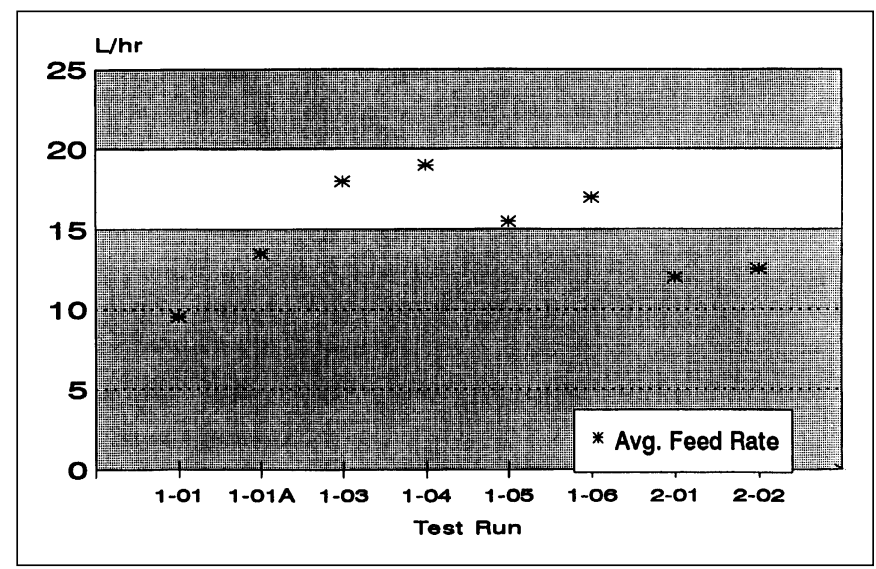

Figure 12. Average Feed Rate vs. Time

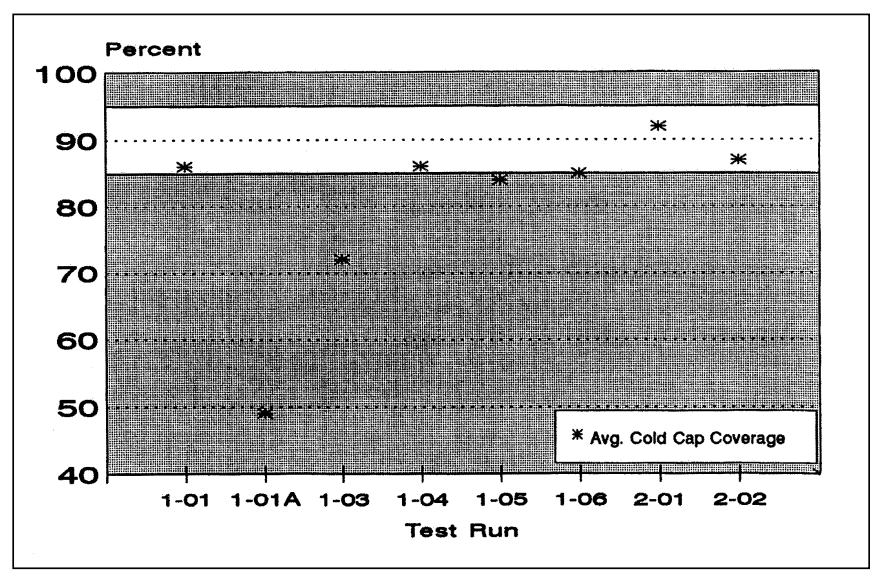

Figure 14. Average Percent Cold Cap Coverage vs. Time

Figures 14 and 15 show average cold cap coverage and average melter power, respectively.

Optimum cold cap coverage was in the range of 85 to $90 \%$ and could be controlled by the feed rate. The target for melter power was $\sim 10 \mathrm{~kW}$. The average internal glass temperature for the SVS-III series test runs is shown in Figure 16. The average melt temperature was maintained within $\sim 20^{\circ} \mathrm{C}$ of $1,140^{\circ} \mathrm{C}$ during all eight test runs in the SVS-III test series.

Operator control of the melter parameters improved throughout the SVS-III test series. Average melter power and internal glass temperature were maintained within the target range for all eight test runs. Average feed rate, plenum temperature, and cold cap coverage varied more widely; with the majority of the data points within or near the target range.

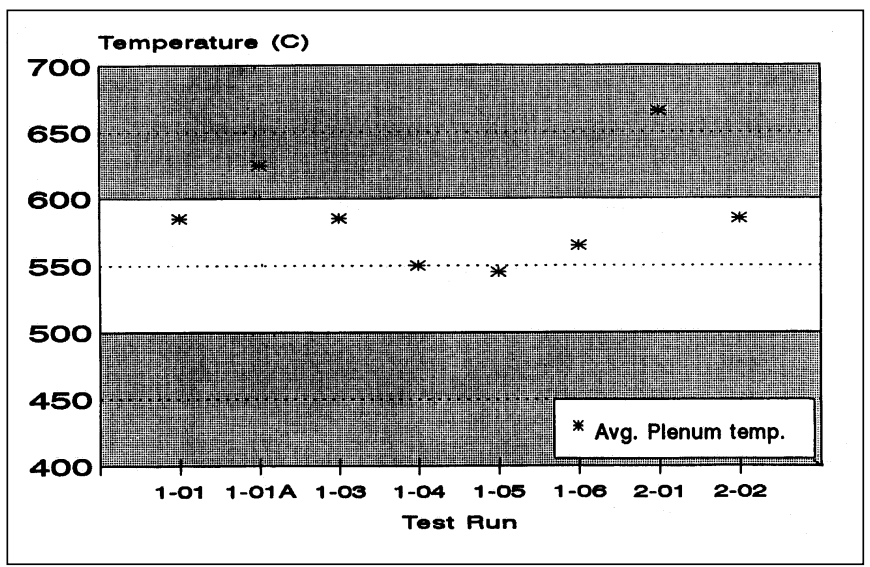

Figure 13. Average Plenum Temperature vs. Time

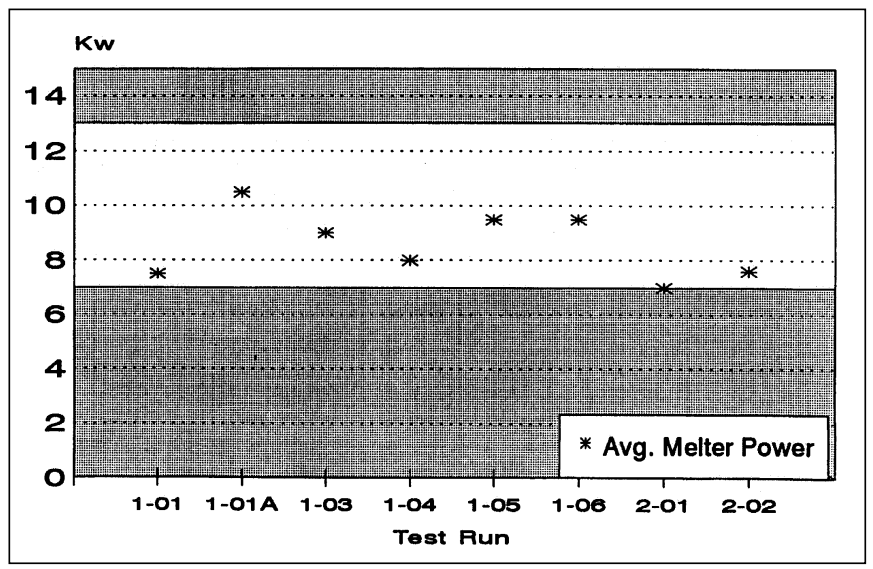

Figure 15. Average Melter Power vs. Time

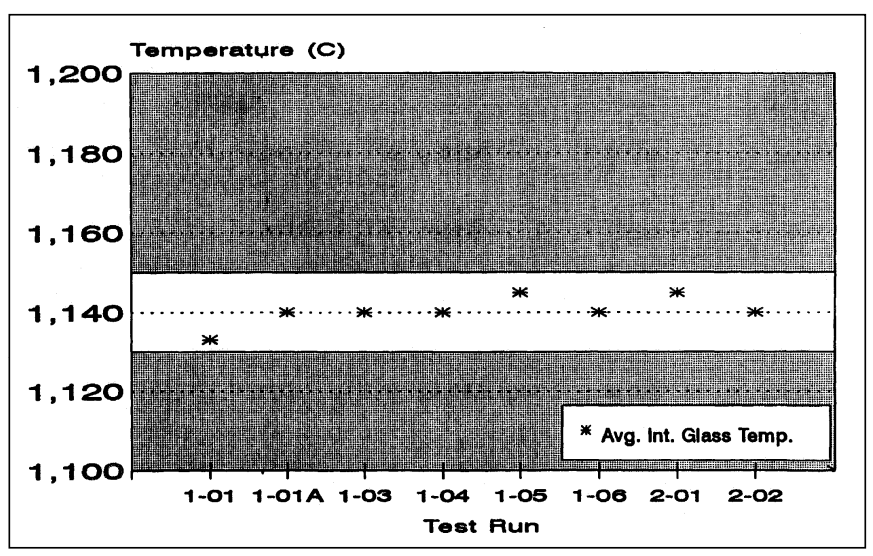

Figure 16. Average Internal Glass Pool Temperature vs. Time 


\subsubsection{Redox Behavior}

One goal of the SVS-III test series was to confirm the applicability of the Redox Forecasting Model developed during FACTS and SVS-I testing. The model correlates the redox state of the glass product, as measured by the $\mathrm{Fe}^{+2} / \mathrm{Fe}^{+3}$ ratio, with the relative amounts of nitrates, organic carbon, and total solids (i.e., IFO) in the slurry feed.

Prediction and control of the redox state of the glass product was problematic throughout the SVS-III test series. Figure 17 shows the $\log \mathrm{Fe}^{+2} / \mathrm{Fe}^{+3}$ versus IFO data for the FACTS, SVS-I, and SVS-III series. For the SVS-III series data points, the IFO value is a target IFO value used to calculate the amount of sugar to be added to the feed. The ferrous-to-ferric ratio is the steady state average. Figure 18 shows the $\log \mathrm{Fe}^{+2} / \mathrm{Fe}^{+3}$ data for the SVS-III test runs as a function of measured IFO. The IFO value was calculated from A\&PC Lab analysis values for nitrates (with an added correction for the nitrates from the zirconyl oxynitrate), TOC, $\% \mathrm{TS}$, and the post-sugar tank volumes. Calculated and measured IFO values are significantly different for Runs 1-04', 2-01, and 2-02, but general behavior trends are consistent. The lack of agreement between calculated and measured IFO values can be accounted for by the variations in percent total solids in the slurries. In the 1-04' slurry, for instance, the measured \% TS was 44.3, while 50\% TS was used in calculating the target IFO.

The implications of the Redox Forecasting Model, as shown in Figures 17 and 18, are that a lower IFO limit of $\sim 2.6$ separates the range of predictable oxidizing behavior from a region where small changes in sugar / nitrates concentrations in the slurry have a large effect on the redox state of the glass product.

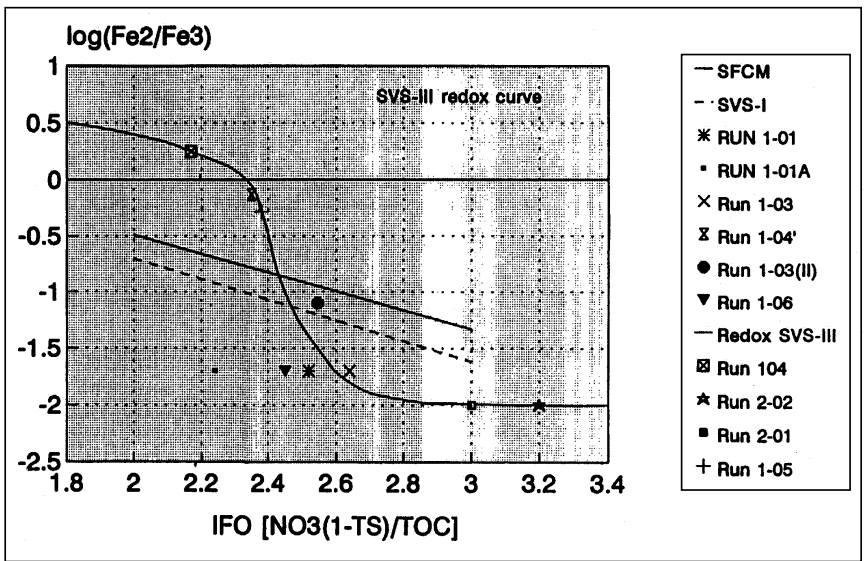

Figure 17. Redox Curves for Slurry-fed Ceramic Melter (SFCM), SVS-I, and SVS-III

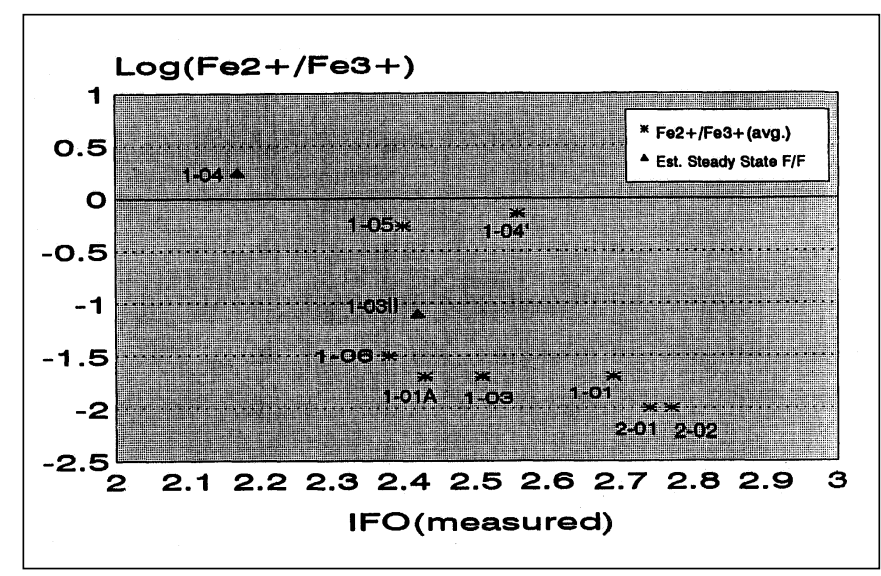

Figure 18. SVS-III Redox Values vs. Measured IFOs

The target slurry composition was unchanged in Runs 1-03, 1-04, 1-05, 1-06, 2-01, and 2-02, with the exception that the amounts of nitrates and sugar were varied to achieve different $\mathrm{Fe}^{+2} / \mathrm{Fe}^{+3}$ ratios. The slurry feed for Runs 1-01 and 1-01A contained more alumina, iron, and nitrates than the target feed composition for Runs 1-03 through 2-02.

The redox behavior of the glass melts in SVS-III Runs 1-03 through 2-02 did not follow the IFO model developed during FACTS and SVS-I testing in that the ferrous-to-ferric ratios measured in the glass did not correlate to the ratios predicted by the model. The SVS-III curve for $\log \mathrm{Fe}^{+2} / \mathrm{Fe}^{+3}$ versus IFO (Figure 17) indicates that in the IFO range of 2.8 to 2.4 , the ferrous-to-ferric ratio can increase from $\sim 0.01$ to $\sim 0.9$. The Redox Forecasting Model, based on FACTS and SVS-1, predicts very little change in the ratio over this IFO range.

In order to investigate the influence of changes in the slurry composition; particularly nitrates and nitrites, total organic carbon, $\mathrm{Fe}_{2} \mathrm{O}_{3}$, and noble metals (i.e., $\mathrm{Pd}, \mathrm{Rh}, \mathrm{Ru}$ ) on the applicability of the IFO model; a series of crucible melt tests was conducted by the Vitrification Lab. 
In the nitrates / carbon tests, five sets of slurry samples were prepared with the same IFO (2.33), but with different amounts of nitrates and carbon. The base slurry contained 110,000 ppm nitrates and 24,034 ppm TOC. To make up the remaining four sample sets, $+15 \% \mathrm{NO}_{3}$ and $\mathrm{TOC},+30 \% \mathrm{NO}_{3}$ and $\mathrm{TOC},+15 \%$ water and TOC, and $+30 \%$ water and TOC were added to the base slurry. The slurry was melted in crucibles in the Vitrification Lab and analyzed by the A\&PC Lab for $\mathrm{Fe}^{+2} / \mathrm{Fe}^{+3}$. The test results shown in Table 10 indicate that the $\mathrm{Fe}^{+2} / \mathrm{Fe}^{+3}$ ratio depends on the total amounts of nitrates and carbon as well as their relative amounts, and that the IFO-to-Fe $\mathrm{Fe}^{+2} / \mathrm{Fe}^{+3}$ relationship is not as straightforward as observed in the FACTS and SVS-I test series. To minimize the effects of this variability on the Redox Forecasting Model, the nitrate concentration target should not significantly change and the ferrous-to-ferric ratio should be adjusted by varying the sugar concentration.

Table 10: IFO / Redox Model Studies

\begin{tabular}{|c|c|c|c|c|}
\hline \multicolumn{5}{|c|}{ Effects of Concentrations of Nitrates and Sugar --- IFO=2.33 } \\
\hline Sample ID & $\mathrm{Fe}^{+2} / \mathrm{Fe}^{+3}$ & & & \\
\hline base slurry & 0.10 & & & \\
\hline base $+15 \% \mathrm{NO}_{3}$ and $+15 \%$ TOC & 0.40 & & & \\
\hline base $+30 \% \mathrm{NO}_{3}$ and $+30 \%$ TOC & 1.17 & & & \\
\hline base $+15 \%$ water and $+15 \%$ TOC & 2.02 & & & \\
\hline base $+15 \%$ water and $+15 \%$ TOC & 1.66 & & & \\
\hline \multicolumn{5}{|l|}{ Effects of Nitrates / Nitrites and Noble Metals } \\
\hline & IFO: & 2.25 & 2.35 & 2.45 \\
\hline \multicolumn{5}{|c|}{$\mathrm{Fe}^{+2} / \mathrm{Fe}^{+3}$} \\
\hline Sample ID & & 0.51 & 0.36 & 0.10 \\
\hline slurry $\left(\mathrm{NaNO}_{2}, \mathrm{NaNO}_{3}, \mathrm{Pd} / \mathrm{Rh} / \mathrm{Ru}, \mathrm{HNO}_{3}\right)$ & & 0.62 & 0.49 & 0.53 \\
\hline slurry $\left(\mathrm{HNO}_{3}, \mathrm{Pd} / \mathrm{Rh} / \mathrm{Ru}\right)$ & & 0.62 & 0.42 & 0.22 \\
\hline slurry $\left(\mathrm{NaNO}_{2}, \mathrm{NaNO}_{3}, \mathrm{HNO}_{3}\right)$ & & 1.55 & 1.48 & 1.18 \\
\hline \multicolumn{5}{|l|}{ Effects of Fe Concentrations } \\
\hline Sample ID & $\mathrm{Fe}^{+2} / \mathrm{Fe}^{+3}$ & & & \\
\hline base slurry & 0.32 & & & \\
\hline base $+10 \% \mathrm{Fe}_{2} \mathrm{O}_{3}$ & 0.34 & & & \\
\hline base $+15 \% \mathrm{Fe}_{2} \mathrm{O}_{3}$ & 0.31 & & & \\
\hline
\end{tabular}

To determine the effects of nitrate sources, nitrites, and noble metals on the $\mathrm{Fe}^{+2} / \mathrm{Fe}^{+3}$ ratio, slurry samples were prepared with various combinations of nitrates, nitrites, and noble metals as well as three different IFO values. The results are shown in Table 10. Slurries containing sodium nitrite show a sensitive redox response to changes in the IFO, while slurries without sodium nitrite are relatively insensitive in the IFO range investigated. Within the same IFO range, the slurry containing sodium nitrate, but no sodium nitrite, produces glass with a much higher ferrous-to-ferric ratio than slurries containing neither or both components. The presence of noble metals appears to have little effect on redox behavior.

To evaluate the effects of higher $\mathrm{Fe}_{2} \mathrm{O}_{3}$ concentrations in the feed slurry on the redox state of the glass, the ferrous-to-ferric ratios of a base slurry, with $10 \%$ higher $\mathrm{Fe}_{2} \mathrm{O}_{3}$ and with $15 \%$ higher $\mathrm{Fe}_{2} \mathrm{O}_{3}$, were compared. Increasing the concentration of $\mathrm{Fe}_{2} \mathrm{O}_{3}$ in the feed slurry had no effect on the redox state of the glass product at typical $\mathrm{Fe}_{2} \mathrm{O}_{3}$ concentration levels $(\sim 11$ weight \%). 


\subsection{Airlift Glass Sample Analysis}

Average normalized oxide concentrations and target concentrations for the major species $\left(\mathrm{Al}_{2} \mathrm{O}_{3}, \mathrm{~B}_{2} \mathrm{O}_{3}\right.$, $\mathrm{Fe}_{2} \mathrm{O}_{3}, \mathrm{~K}_{2} \mathrm{O}, \mathrm{Li}_{2} \mathrm{O}, \mathrm{Na}_{2} \mathrm{O}, \mathrm{SiO}_{2}$, and $\mathrm{ZrO}_{2}$ ) in the final slurries and in the airlift glasses from the SVS-III test series are shown in Figures 19 through 26. The concentrations are plotted as average normalized weight percent oxides and were determined by ICP analysis performed by the A\&PC Lab.

The same target glass composition was used for Runs 1-01 through 2-02 with the exception that the composition for Runs 1-01 and 1-01A was higher in alumina, iron, and nitrates. For Run 2-02, a portion of the feed from Run 2-01 was shimmed with nitric acid to make a more oxidized melt. The airlift glasses from Run 2-02 were therefore not analyzed for composition.

The average concentrations of alumina are shown in Figure 19. The analyzed composition of the airlift glass was very close to the target in all cases. There was more scatter in the final slurry analysis, with close agreement between slurry and glass analyses only in Runs 1-05, 1-06, and 2-01. Analysis for $\mathrm{B}_{2} \mathrm{O}_{3}$ concentrations, shown in Figure 20, was consistently low relative to the target throughout the SVS-III test series. Again, the slurry analysis showed more scatter with data points both above and below the target.

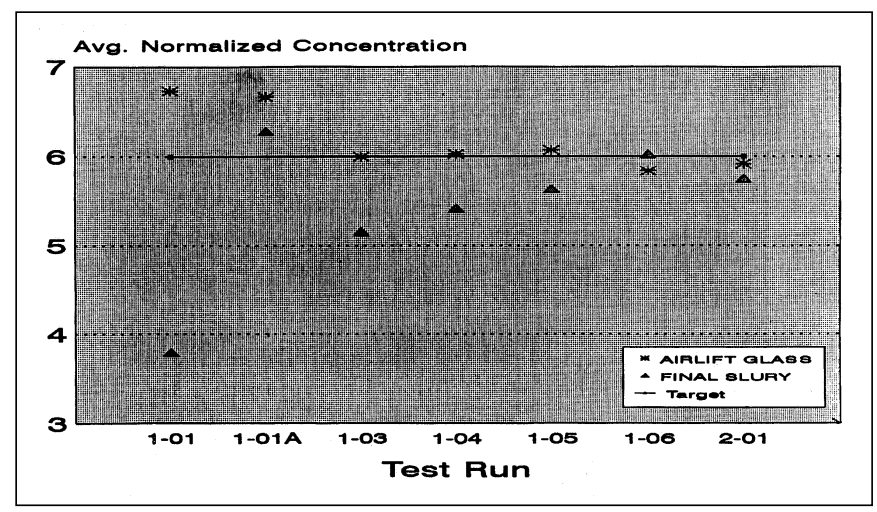

Figure 19. Normalized Oxide Concentration for $\mathrm{Al}_{2} \mathrm{O}_{3}$

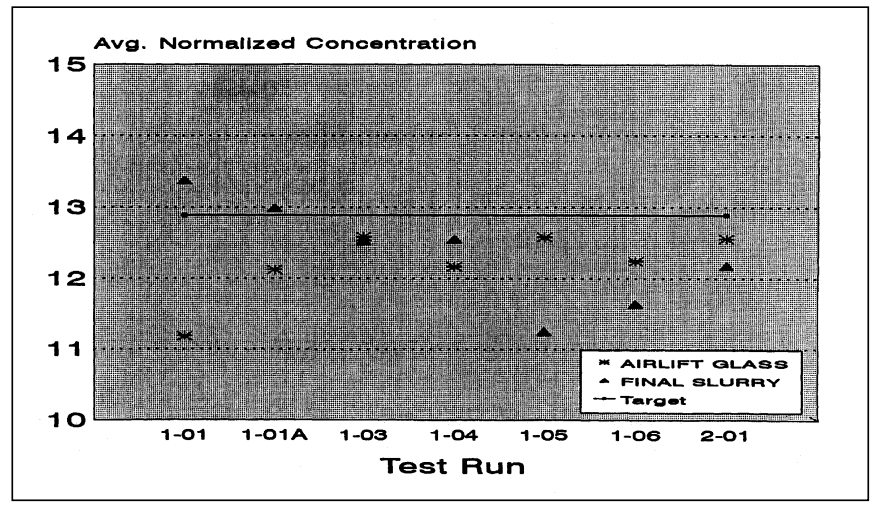

Figure 20. Normalized Oxide Concentration for $\mathrm{B}_{2} \mathrm{O}_{3}$

Figure 21 shows the average normalized $\mathrm{Fe}_{2} \mathrm{O}_{3}$ concentrations in glass and slurry from the SVS-III test runs. Analyzed concentrations were high for both the glass and slurry for most of the samples tested. Good agreement between the glass, slurry, and target was realized only in run 1-05, and between the glass and target only in Runs 1-03 and 1-06. Concentrations of $\mathrm{K}_{2} \mathrm{O}$, shown in Figure 22, were consistently low relative to the target, with good agreement between glass and slurry analysis. $\mathrm{Li}_{2} \mathrm{O}$ concentrations, shown in Figure 23 , were, in general, predominantly slightly below target for the glass samples and slightly above target for the slurry, with the exception of Runs 1-06 and 2-01 in which the slurry analysis was below target.

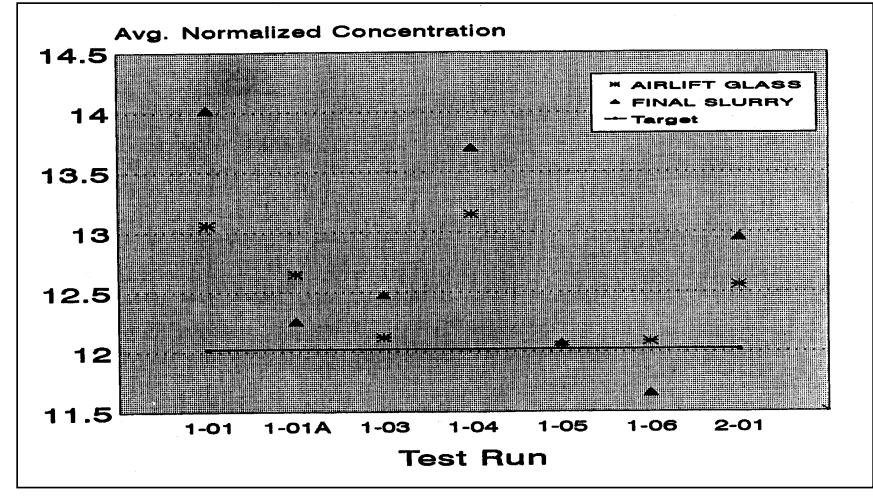

Figure 21. Normalized Oxide Concentration for $\mathrm{Fe}_{2} \mathrm{O}_{3}$

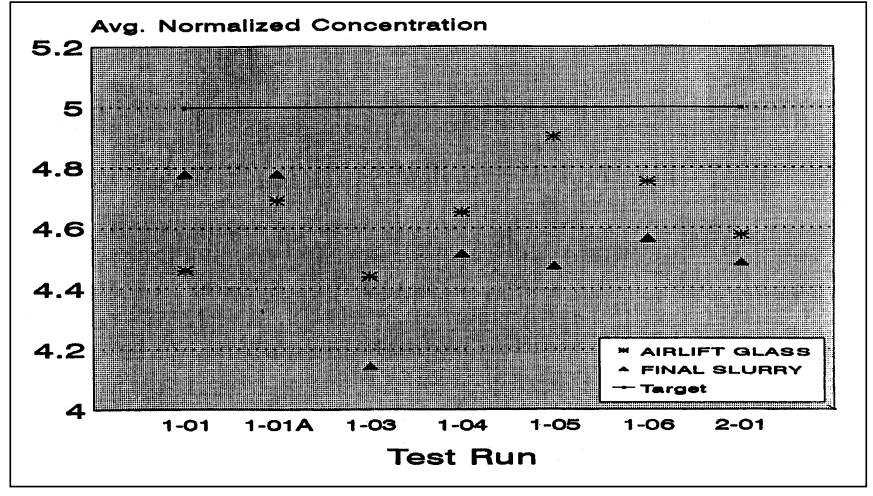

Figure 22. Normalized Oxide Concentration for $\mathrm{K}_{2} \mathrm{O}$ 


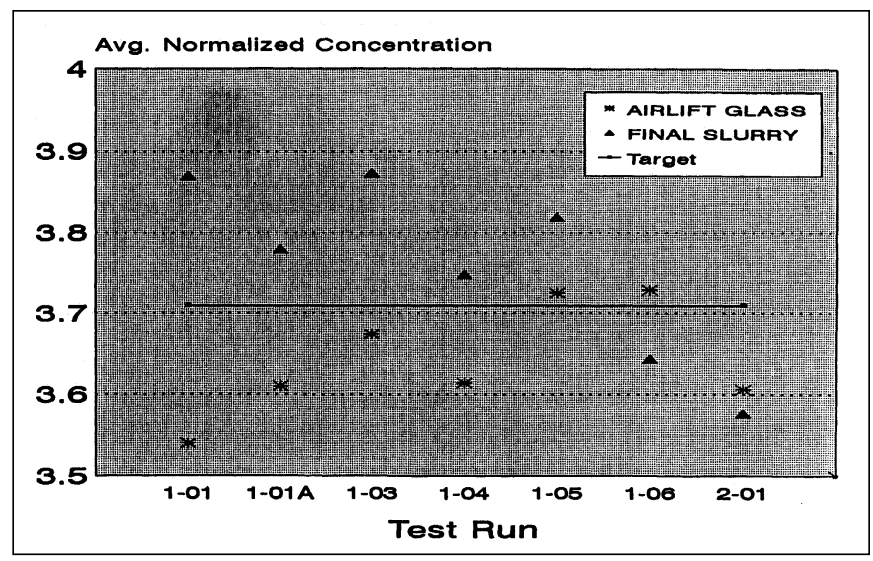

Figure 23. Normalized Oxide Concentration for $\mathrm{Li}_{2} \mathrm{O}$

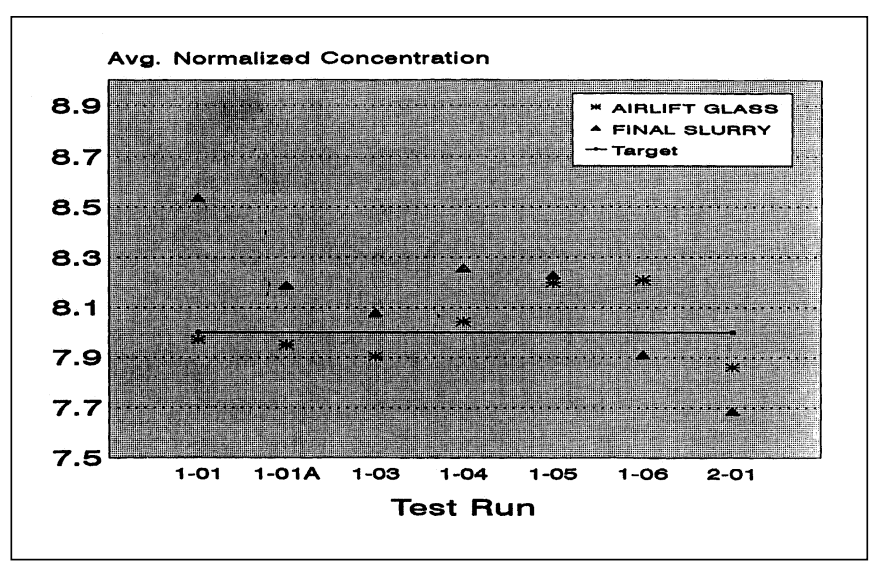

Figure 24. Normalized Oxide Concentration for $\mathrm{Na}_{2} \mathrm{O}$

$\mathrm{Na}_{2} \mathrm{O}$ concentrations, shown in Figure 24, were close to the target value for all of the airlift glasses as well as for most of the slurry samples, except those from Runs 1-01 and 2-01. Agreement between glass and slurry analysis was good. Average normalized $\mathrm{SiO}_{2}$ concentrations are shown in Figure 25. In general, the analyzed values were higher than the target with more scatter in the data from the slurry analyses. $\mathrm{ZrO}_{2}$ concentrations, shown in Figure 26, were close to the target value for all of the airlift glasses as well as for most of the slurry samples, except those from Runs 1-01 and 2-01.

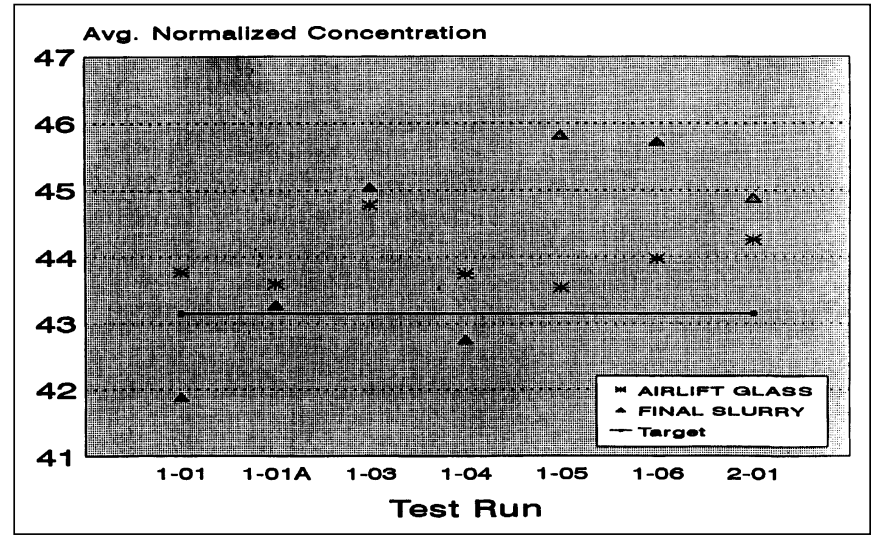

Figure 25. Normalized Oxide Concentration for $\mathrm{SiO}_{2}$

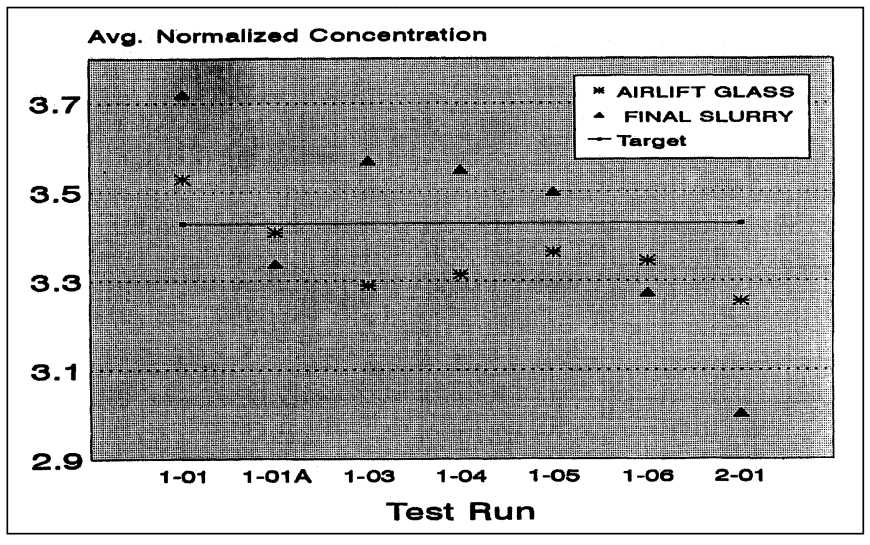

Figure 26. Normalized Oxide Concentration for $\mathrm{ZrO}_{2}$ 


\subsection{Summary}

The SVS-III test series was designed to collect additional data points on the $\log \mathrm{Fe}^{+2} / \mathrm{Fe}^{+3}$ versus IFO curve that defines the Redox Forecasting Model. As it became apparent through Runs 1-04, 1-05, and 1-06, the redox data were not conforming to predictions. The model was reinvestigated in order to develop a better understanding of the factors driving redox behavior. It was found that the total amounts of nitrates, nitrites, and carbon, as well as the ratio of nitrates to carbon, affect the redox dynamics of the glass melt. It was also discovered that chemical analysis for nitrate concentration was consistently under reported. This was due to the presence of zirconyl oxynitrate complexes that did not dissociate and, therefore, were not detected by the analysis. The Redox Forecasting Model was subsequently adjusted to account for the difference.

Indications from the SVS-III redox data are that there is a lower IFO limit of $\sim 2.6$ separating a region of predictable oxidizing behavior in the glass melt (IFO > 2.6) from a region where small changes in the sugar / nitrates concentrations in the slurry have large effects on the redox state of the glass product $(\mathrm{IFO}<2.6)$.

Proposed full-scale testing objectives for the Integrated Slurry Run / Integrated Cold Ops Test in the VF progression were designed to reevaluate the Redox Forecasting Model in light of the understanding gained from the SVS-III test series. Slurry batch compositions will target ferrous-to-ferric ratios in the high oxidizing region $\left(\mathrm{Fe}^{+2} / \mathrm{Fe}^{+3}<0.01\right)$, in two middle regions $\left(\mathrm{Fe}^{+2} / \mathrm{Fe}^{+3} \sim 0.05\right.$ to $0.1, \mathrm{Fe}^{+2} / \mathrm{Fe}^{+3} \sim 0.2$ to 0.3$)$, and a highly reduced region $\left(\mathrm{Fe}^{+2} / \mathrm{Fe}^{+3} \sim 0.5\right)$.

Full-scale melter operations will target a redox ratio on the oxidizing end of the spectrum (IFO $>2.6$ ) where the ferrous-to-ferric ratio is less sensitive to variations in the nitrate and carbon concentrations.

The SVS-III test series successfully demonstrated that a glass product with acceptable composition can be made consistently from a slurry recipe incorporating waste simulant and glass-former components. In addition, melter operation parameters; such as feed rate, cold cap coverage, glass melt and plenum temperatures, and melter power; were controlled successfully to provide steady state operating conditions during the melter test runs. 


\subsection{ACRONYMS}

$\begin{array}{ll}\text { \%TS } & \text { Percent Total Solids } \\ \text { A\&PC } & \text { Analytical and Process Chemistry } \\ \text { CFMT } & \text { Concentrator Feed Makeup Tank } \\ \text { CHT } & \text { Condensate Hold Tank } \\ \text { CPC } & \text { Chemical Process Cell } \\ \text { CTS } & \text { Component Test Stand } \\ \text { DCS } & \text { Distributed Control System } \\ \text { DOE } & \text { U.S. Department of Energy } \\ \text { DSRT } & \text { Direct Slurry Redox Testing } \\ \text { FACTS } & \text { Functional and Checkout Testing of Systems } \\ \text { FHT } & \text { Feed Hold Tank } \\ \text { GC } & \text { Gas Chromatograph } \\ \text { HEME } & \text { High-Efficiency Mist Eliminator } \\ \text { HEPA } & \text { High-Efficiency Particulate Air Filter } \\ \text { HLW } & \text { High-Level Waste } \\ \text { ICP } & \text { Inductively Coupled Plasma } \\ \text { IFO } & \text { Index of Feed Oxidation } \\ \text { IR } & \text { Infrared } \\ \text { LLWTF } & \text { Low-Level Waste Treatment Facility } \\ \text { MFHT } & \text { Melter Feed Hold Tank } \\ \text { MFT } & \text { Melter Feed Tank } \\ \text { NFS } & \text { Nuclear Fuel Services Company } \\ \text { OG } & \text { Off Gas } \\ \text { PUREX } & \text { Plutonium Uranium Extraction } \\ \text { REDOX } & \text { Oxygen Reduction } \\ \text { SBS } & \text { Submerged Bed Scrubber } \\ \text { SCR } & \text { Selective Catalytic Reactor } \\ \text { SFCM } & \text { Slurry-Fed Ceramic Melter } \\ \text { SMT } & \text { Slurry Mix Tank } \\ \text { SVS III } & \text { Scaled Vitrification System III } \\ \text { SWCT } & \text { Scrubber Water Collection Tank } \\ \text { T/C } & \text { Thermocouple } \\ \text { THOREX } & \text { Thorium Extraction } \\ \text { TOC } & \text { Total Organic Carbon } \\ \text { VF } & \text { Vitrification Facility } \\ \text { VS } & \text { Venturi Scrubber } \\ \text { VTCR } & \text { Vitrification Test Control Room } \\ \text { VTF } & \text { Vitrification Test Facility } \\ \text { WAPS } & \text { Waste Acceptance Product Specifications } \\ \text { WELCO } & \text { Westinghouse Electric Company } \\ \text { WQR } & \text { Waste Qualification Report } \\ \text { WVDP } & \text { West Valley Demonstration Project } \\ \text { WVNS } & \text { West Valley Nuclear Services Company } \\ & \end{array}$




\section{APPENDIX A:}

\subsection{SVS-III RUN 1-01}

\subsection{Objectives}

SVS-III Run 1-01 concentrated on the following objectives:

- Defining and testing feed makeup strategy

- Controlling the steady state redox ratio at approximately 0.20 during the melter operations.

\subsection{Feed Preparation and Analysis}

Run 1 of series 1 for the SVS-III testing used the heel from the nitrate run. The nitrate run was made to shake-down the system. The FHT volume indicator showed that the heel was approximately $546 \mathrm{~L}$. Batch formulations for $480 \mathrm{~kg}$ of glass were initially made and the $966 \mathrm{~L}$ of simulant was prepared in the SMT. The simulant was then mixed with the existing heel. The total volume of simulant and heel was 1,352 L. The volume additions indicate that the volume of heel should be $386 \mathrm{~L}$. The difference between the measured heel volume and the one estimated after the transfer is $160 \mathrm{~L}$, and is attributed to plugging of the measurement probe.

The simulant was then boiled down to $642 \mathrm{~L}$. Later on, an additional amount of simulant was prepared, along with the glass-former slurry, for a total glass batch of $800 \mathrm{~kg}$. The amounts of glass-former slurry and additional simulant were calculated based on the waste simulant analysis. The normalized glass-former analysis is shown in Table A-1. The analysis consisted of five duplicate analyses. The analysis indicated the deficiencies shown in Table A-2.

Due to the inaccurate glass-former slurry analysis, the transfer of the glass-former slurry to the waste simulant was done based on the weights of the chemicals that were added to the SMT. The combined volume of the waste simulant and the glass-former slurry was 1,936 L. Table A-3 shows the total amounts of chemicals that were added to the feed. This table does not account for the chemicals present in the heel.

The chemical composition of the final slurry is shown in Table A-4. Again, the analysis indicated discrepancies in the analyzed and in the target feeds. Results indicate that the glass samples more accurately represent the feed composition, as determined from the weights of the chemicals added. 
Table A-1. Chemical Analysis of Glass-Former Slurry (weight \% basis)

\begin{tabular}{|c|c|c|c|c|c|c|c|c|c|c|c|c|c|c|c|}
\hline Analysis & $\# 1$ & $\# 2$ & $\# 3$ & $\# 4$ & $\# 5$ & $\# 6$ & $\# 7$ & $\# 8$ & $\# 9$ & $\# 10$ & Avg. S & Std. Dev. & $\begin{array}{c}\text { Std.Dev. } \\
\quad \div \\
\text { Avg. }\end{array}$ & Glass-former & \% Diff. \\
\hline $\mathrm{Al}_{2} \mathrm{O}_{3}$ & 0.27 & 0.25 & 0.26 & 0.19 & 0.27 & 0.23 & 0.25 & 0.16 & 0.23 & 0.18 & 0.23 & 0.04 & 0.16 & 5.63 & 95.93 \\
\hline $\mathrm{B}_{2} \mathrm{O}_{3}$ & 14.86 & 14.56 & 16.81 & 14.23 & 16.82 & 18.55 & 13.92 & 20.63 & 11.63 & 11.41 & 15.34 & 2.76 & 0.18 & 17.17 & 10.68 \\
\hline $\mathrm{BaO}$ & 0.05 & 0.05 & 0.06 & 0.05 & 0.06 & 0.05 & 0.05 & 0.05 & 0.04 & 0.05 & 0.05 & 0.01 & 0.11 & 0.08 & \\
\hline $\mathrm{CaO}$ & 0.17 & 0.15 & 0.17 & 0.17 & 0.19 & 0.16 & 0.14 & 0.15 & 0.14 & 0.15 & 0.16 & 0.02 & 0.10 & 0.15 & -7.58 \\
\hline $\mathrm{Ce}_{2} \mathrm{O}_{3}$ & 0.17 & 0.13 & 0.16 & 0.08 & 0.15 & 0.08 & 0.19 & 0.08 & 0.19 & 0.08 & 0.13 & 0.04 & 0.33 & 0.26 & \\
\hline $\mathrm{Fe}_{2} \mathrm{O}_{3}$ & 6.69 & 6.01 & 6.65 & 6.75 & 7.03 & 6.50 & 5.66 & 6.47 & 5.54 & 6.15 & 6.35 & 0.47 & 0.07 & 5.68 & -11.65 \\
\hline $\mathrm{K}_{2} \mathrm{O}$ & 3.32 & 2.98 & 3.33 & 3.31 & 3.45 & 3.22 & 2.83 & 3.24 & 2.78 & 2.97 & 3.14 & 0.22 & 0.07 & 4.15 & 24.34 \\
\hline $\mathrm{Li}_{2} \mathrm{O}$ & 4.76 & 4.23 & 4.73 & 4.72 & 5.12 & 4.58 & 4.02 & 4.57 & 3.96 & 4.24 & 4.49 & 0.35 & 0.08 & 4.99 & 9.91 \\
\hline $\mathrm{MgO}$ & 1.01 & 0.89 & 1.01 & 1.02 & 1.08 & 0.99 & 0.86 & 0.98 & 0.83 & 0.91 & 0.96 & 0.08 & 0.08 & 1.06 & 9.89 \\
\hline $\mathrm{MnO}$ & 0.64 & 0.67 & 0.62 & 0.62 & 0.67 & 0.64 & 0.69 & 0.72 & 0.68 & 0.68 & 0.66 & 0.03 & 0.05 & 0.60 & -9.77 \\
\hline $\mathrm{Na}_{2} \mathrm{O}$ & 6.26 & 5.58 & 6.18 & 6.23 & 6.63 & 6.13 & 5.25 & 6.05 & 5.18 & 5.62 & 5.91 & 0.45 & 0.08 & 6.55 & 9.75 \\
\hline $\mathrm{NiO}$ & 0.14 & 0.09 & 0.13 & 0.10 & 0.14 & 0.10 & 0.11 & 0.10 & 0.11 & 0.09 & 0.11 & 0.02 & 0.16 & 0.13 & \\
\hline $\mathrm{P}_{2} \mathrm{O}_{5}$ & 0.59 & 0.49 & 0.58 & 0.55 & 0.68 & 0.53 & 0.53 & 0.59 & 0.48 & 0.53 & 0.55 & 0.05 & 0.10 & 0.62 & 9.97 \\
\hline $\mathrm{SO}_{3}$ & 0.38 & 0.20 & 0.39 & 0.20 & 0.30 & 0.21 & 0.31 & 0.21 & 0.36 & 0.26 & 0.28 & 0.07 & 0.26 & -0.11 & 358.18 \\
\hline $\mathrm{SiO}_{2}$ & 57.73 & 61.26 & 56.04 & 59.03 & 54.34 & 55.36 & 62.71 & 53.37 & 65.40 & 64.27 & 58.95 & 4.06 & 0.07 & 48.79 & -20.84 \\
\hline $\mathrm{TiO}_{2}$ & 0.00 & 0.00 & 0.00 & 0.00 & 0.00 & 0.00 & 0.00 & 0.00 & 0.00 & 0.00 & 0.00 & 0.00 & err & 0.86 & 100.0 \\
\hline $\mathrm{ZrO}_{2}$ & 2.75 & 2.45 & 2.72 & 2.74 & 2.91 & 2.65 & 2.33 & 2.63 & 2.30 & 2.42 & 2.59 & 0.19 & 0.07 & 2.75 & 5.71 \\
\hline Others & 0.20 & 0.01 & 0.18 & 0.01 & 0.16 & 0.01 & 0.15 & 0.00 & 0.15 & 0.00 & 0.08 & & & 0.63 & \\
\hline Totals & 100.0 & 100.0 & 100.0 & 100.0 & 100.0 & 100.0 & 100.0 & 100.0 & 100.0 & 100.0 & 100.0 & & & 100.0 & \\
\hline
\end{tabular}

Table A-2. Variation in Major Components of the Glass-Former Slurry

\begin{tabular}{ll} 
Oxide & \% Difference \\
$\mathrm{Al}_{2} \mathrm{O}_{3}$ & $96 \%$ lower \\
$\mathrm{B}_{2} \mathrm{O}_{3}$ & $11 \%$ lower \\
$\mathrm{Fe}_{2} \mathrm{O}_{3}$ & $12 \%$ higher \\
$\mathrm{K}_{2} \mathrm{O}$ & $24 \%$ lower \\
$\mathrm{Li}_{2} \mathrm{O}$ & $10 \%$ lower \\
$\mathrm{Na}_{2} \mathrm{O}$ & $10 \%$ lower \\
$\mathrm{SiO}_{2}$ & $21 \%$ higher \\
$\mathrm{ZrO}_{2}$ & $6 \%$ lower \\
\hline
\end{tabular}


Table A-3. Chemical Addition Totals

\begin{tabular}{|c|c|c|c|c|}
\hline Chemical Name & Formula & e Simulant (kg) & Glass Formers (kg) & Total $(\mathrm{kg})$ \\
\hline Aluminum Hydroxide & $\mathrm{Al}(\mathrm{OH})_{3}$ & 7.085 & 43.92 & 51.005 \\
\hline Boron Oxide & $\mathrm{B}_{2} \mathrm{O}_{3}$ & 0.29 & 87.7 & 87.99 \\
\hline Barium Hydroxide & $\mathrm{Ba}(\mathrm{OH})_{2}$ & 1.57 & 0.8 & 2.37 \\
\hline Calcium Carbonate & $\mathrm{CaCO}_{3}$ & 2.52 & 1.32 & 3.84 \\
\hline Cerium Hydroxide & $\mathrm{Ce}(\mathrm{OH})_{4}$ & 1.89 & 1.69 & 3.58 \\
\hline Cesium Hydroxide & $\mathrm{CsOH}$ & 0.45 & & 0.45 \\
\hline Copper Hydroxide & $\mathrm{Cu}(\mathrm{OH})_{2}$ & 0.29 & 0.11 & 0.4 \\
\hline Ferric Hydroxide & $\mathrm{Fe}(\mathrm{OH})_{3}$ & 566.36 & 293.95 & 860.31 \\
\hline Lanthanum Oxide & $\mathrm{La}_{2} \mathrm{O}_{3}$ & 0.19 & 0.25 & 0.44 \\
\hline Lithium Hydroxide & $\mathrm{LiOH}$ & & 71.55 & 71.55 \\
\hline Magnesium Hydroxide & $\mathrm{Mg}(\mathrm{OH})_{2}$ & 0.30 & 7.86 & 8.16 \\
\hline Manganese Dioxide & $\mathrm{MnO}_{2}$ & 3.36 & 3.79 & 7.15 \\
\hline Monosodium Phosphate & $\mathrm{NaH}_{2} \mathrm{PO}_{4}$ & 9.74 & 5.25 & 14.99 \\
\hline Neodymium Oxide & $\mathrm{Nd}_{2} \mathrm{O}_{3}$ & 0.86 & 0.62 & 1.48 \\
\hline Nickel Hydroxide & $\mathrm{Ni}(\mathrm{OH})_{2}$ & 1.49 & 0.84 & 2.33 \\
\hline Nitric Acid ( $35 \%$ ) & $\mathrm{HNO}_{3}$ & & 801.45 & 801.45 \\
\hline Palladium Oxide & $\mathrm{PdO}$ & 0.14 & & 0.14 \\
\hline Potassium Hydroxide & $\mathrm{KOH}$ & 22.90 & 25.3 & 48.2 \\
\hline Rhodium Oxide & $\mathrm{Rh}_{2} \mathrm{O}_{3}$ & 0.10 & & 0.10 \\
\hline Silicon Dioxide & $\mathrm{SiO}_{2}$ & 14.82 & 249.14 & 263.96 \\
\hline Sodium Hydroxide & $\mathrm{NaOH}$ & 4.35 & 31.05 & 35.4 \\
\hline Sodium Metasilicate & $\mathrm{Na}_{2} \mathrm{OSiO}_{2}$ & 1.68 & & 1.68 \\
\hline Sodium Molybdate & $\mathrm{Na}_{2} \mathrm{MoO}_{4}$ & 0.27 & 0.09 & 0.36 \\
\hline Sodium Nitrate & $\mathrm{NaNO}_{3}$ & 11.25 & 7.46 & 18.71 \\
\hline Sodium Nitrite & $\mathrm{NaNO}_{2}$ & 17.28 & 11.52 & 28.8 \\
\hline Sodium Sulfate & $\mathrm{Na}_{2} \mathrm{SO}_{4}$ & 1.95 & & 1.95 \\
\hline Strontium Hydroxide & $\mathrm{Sr}(\mathrm{OH})_{2}$ & 0.12 & & 0.12 \\
\hline Titanium Dioxide & $\mathrm{TiO}_{2}$ & & 4.42 & 4.42 \\
\hline Zeolite IE-96 ${ }^{\circledR}$ & Zeolite IE-96 ${ }^{\circledR}$ & 45.7 & & 45.7 \\
\hline Zeolite TIE-96 ${ }^{\circledR}$ & Zeolite TIE-96 ${ }^{\circledR}$ & 25.45 & & 25.45 \\
\hline Zinc Oxide & $\mathrm{ZnO}$ & 0.10 & & 0.10 \\
\hline Zirconium Oxynitrate & $\mathrm{ZrO}\left(\mathrm{NO}_{3}\right)_{2} \cdot 2 \mathrm{H}_{2} \mathrm{O}$ & 52.06 & 71.65 & 123.71 \\
\hline
\end{tabular}


Table A-4. Composition of the Final Slurry (ICP Analysis)

\begin{tabular}{llllllllll} 
& $\begin{array}{l}\text { Target } \\
\text { Glass } \\
(\mathbf{k g})\end{array}$ & $\begin{array}{l}\text { Analyzed } \\
\text { Simulant } \\
(\mathbf{k g})\end{array}$ & $\begin{array}{l}\text { Calc. } \\
\text { Former } \\
\mathbf{( k g )}\end{array}$ & $\begin{array}{l}\text { Analyzed } \\
\text { Former } \\
\mathbf{( k g})\end{array}$ & $\begin{array}{l}\text { Estimated } \\
\text { Slurry } \\
(\mathbf{k g})\end{array}$ & $\begin{array}{l}\text { Estimated } \\
\text { \% Error }\end{array}$ & $\begin{array}{l}\text { Analyzed } \\
\text { Slurry } \\
(\mathbf{k g})\end{array}$ & $\begin{array}{l}\text { Diff. } \\
(\mathbf{k g})\end{array}$ & \% Diff. \\
& & & & & & & & \\
$\mathrm{Al}_{2} \mathrm{O}_{3}$ & 48.00 & 19.21 & 28.79 & 1.24 & 20.44 & -57.41 & 27.09 & 20.91 & 43.55 \\
$\mathrm{~B}_{2} \mathrm{O}_{3}$ & 103.12 & 15.34 & 87.78 & 82.79 & 98.13 & -4.83 & 95.56 & 7.56 & 7.33 \\
$\mathrm{CaO}$ & 3.84 & 3.09 & 0.75 & 0.85 & 3.94 & 2.66 & 4.07 & -0.23 & -5.97 \\
$\mathrm{Fe} \mathrm{O}_{3}$ & 96.16 & 67.11 & 29.05 & 34.25 & 101.36 & 5.41 & 100.18 & -4.02 & -4.18 \\
$\mathrm{~K}_{2} \mathrm{O}$ & 40.00 & 18.77 & 21.23 & 16.96 & 35.73 & -10.67 & 34.14 & 5.86 & 14.66 \\
$\mathrm{Li} \mathrm{O}_{2}$ & 29.68 & 4.20 & 25.48 & 24.24 & 28.44 & -4.18 & 27.65 & 2.03 & 6.85 \\
$\mathrm{MgO}$ & 7.12 & 1.69 & 5.43 & 5.17 & 6.86 & -3.70 & 6.48 & 0.64 & 8.95 \\
$\mathrm{MnO}$ & 6.56 & 3.47 & 3.09 & 3.58 & 7.05 & 7.50 & 6.43 & 0.13 & 1.97 \\
$\mathrm{Na}_{2} \mathrm{O}$ & 64.00 & 30.53 & 33.47 & 31.90 & 62.43 & -2.46 & 60.98 & 3.02 & 4.72 \\
$\mathrm{P}_{2} \mathrm{O}_{5}$ & 9.60 & 6.45 & 3.15 & 2.99 & 9.44 & -1.62 & 9.10 & 0.50 & 5.26 \\
$\mathrm{SO}_{3}$ & 1.84 & 2.40 & -0.56 & 1.51 & 3.91 & 112.52 & 3.36 & -1.52 & -82.60 \\
$\mathrm{SiO}_{2}$ & 344.60 & 95.26 & 249.34 & 318.16 & 413.42 & 19.97 & 299.20 & 45.40 & 13.18 \\
$\mathrm{TiO}_{2}$ & 6.40 & 1.98 & 4.42 & 0.00 & 1.98 & -69.03 & 5.67 & 0.73 & 11.45 \\
$\mathrm{ZrO}_{2}$ & 27.32 & 13.28 & 14.04 & 13.98 & 27.26 & -0.22 & 26.58 & 0.74 & 2.71 \\
$\mathrm{Others}_{2}$ & 10.88 & 5.27 & 5.61 & 2.06 & 7.32 & & 7.69 & 3.19 & \\
$\mathrm{Total}$ & 799.12 & 288.03 & 511.09 & 539.69 & 827.71 & & 714.18 & 84.94 & \\
\hline
\end{tabular}

Sugar addition to the slurry was based on the analyzed $\mathrm{NO}_{3}$ concentration and the IFO of 2.28. The analyzed $\mathrm{NO}_{3}$ and TOC concentrations in the slurry were 129,900 and 3,880 ppm, respectively. Based on the FHT volume of $1,936 \mathrm{~L}$ and density of $1.37 \mathrm{~kg} / \mathrm{Ll}$, the amount of sugar required for $346 \mathrm{~kg}$ of NO 3 , was $157 \mathrm{~kg}$. The final volume and the density of the slurry in the FHT after sugar addition were $2,147 \mathrm{~L}$ and $1.36 \mathrm{~kg} / \mathrm{L}$, respectively.

The final slurry, after sugar addition, was reanalyzed for $\mathrm{NO}_{3}$ and TOC. The results indicated $\mathrm{NO}_{3}$ as $128,600 \mathrm{ppm}$ and TOC as 25,500 ppm. This gave an IFO of 2.53, a much higher value than the target of 2.28. The measured and calculated IFOs, after correcting for zirconyl nitrate contribution, were 2.69 and 2.45 , respectively. The $\mathrm{NO}_{3}$ mass balance before and after sugar addition indicates that $\mathrm{NO}_{3}$ was $346 \mathrm{~kg}$ before sugar addition and $376 \mathrm{~kg}$ after sugar addition.

The $\mathrm{pH}$ of the feed after addition of chemicals was 1.15. Further investigation of the $\mathrm{NO}_{3}$ mass balance indicated that the $\mathrm{NO}_{3}$ from the zirconyl nitrate solution (containing $21 \% \mathrm{HNO}_{3}$ ) was not included in the $\mathrm{NO}_{3}$ mass balance. This resulted in the final $\mathrm{pH}$ of 1.15. This should not have impacted the redox behavior because sugar additions were based on the analyzed $\mathrm{NO}_{3}$ concentration. Table A-5 shows the characteristics of the feed that was fed to the melter.

Table A-5. Feed Characteristics

\section{Parameters}

$\mathrm{NO}_{3}(\mathrm{ppm})$

TOC (ppm)

Density $(\mathrm{kg} / \mathrm{L})$

$\%$ Total Solids

$\mathrm{pH}$

Volume FHT (L)

Viscosity of Glass (poise) @ $1,100^{\circ} \mathrm{C}$

\section{Amounts}

128,600

25,500

1.36

50

1.15

2,147

84

A-4 


\subsection{Melter Operations}

Figure A-1 shows the $\mathrm{Fe}^{+2} / \mathrm{Fe}^{+3}$ ratio as a function of run hours. The data indicate that the feed is oxidizing and failed to attain a steady state redox ratio. The $\mathrm{Fe}^{+2} / \mathrm{Fe}^{+3}$ ratio was 0.03 at the start of the run, but dropped to less than 0.01 for the next 12 hours. The $\mathrm{Fe}^{+2} / \mathrm{Fe}^{+3}$ ratio peaked at 0.04 at 25 run hours and oxidized again to below 0.01 . The oxidation of the melt from 0.04 to less than 0.01 in 39 hours was attributed to the air in-leakage in the bubbler. The bubbler air in-leakage was stopped at around 50 hours in the run. The redox ratio fluctuated between 0.01 and 0.04 after the air-inleakage was stopped. The average $\mathrm{Fe}^{+2}$ $/ \mathrm{Fe}^{+3}$ ratio was 0.02 for the last 30 hours of the run.

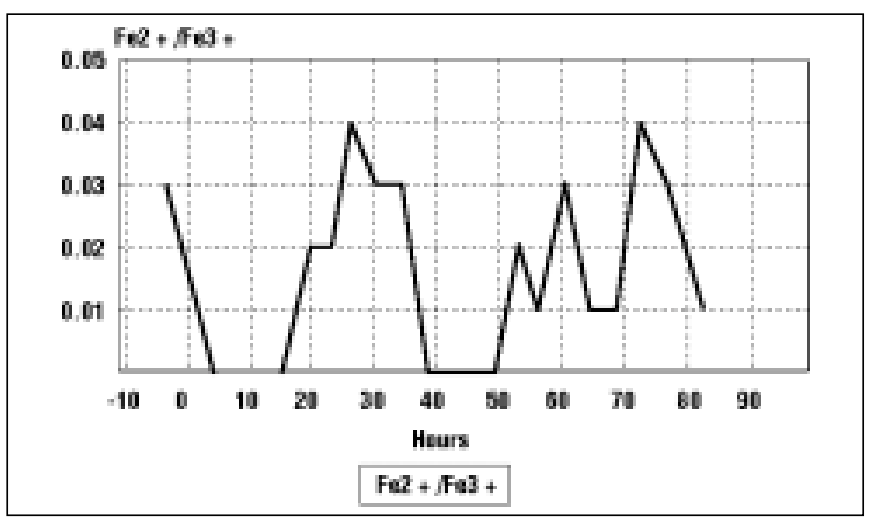

Figure A-1. Redox Ratio vs. Time

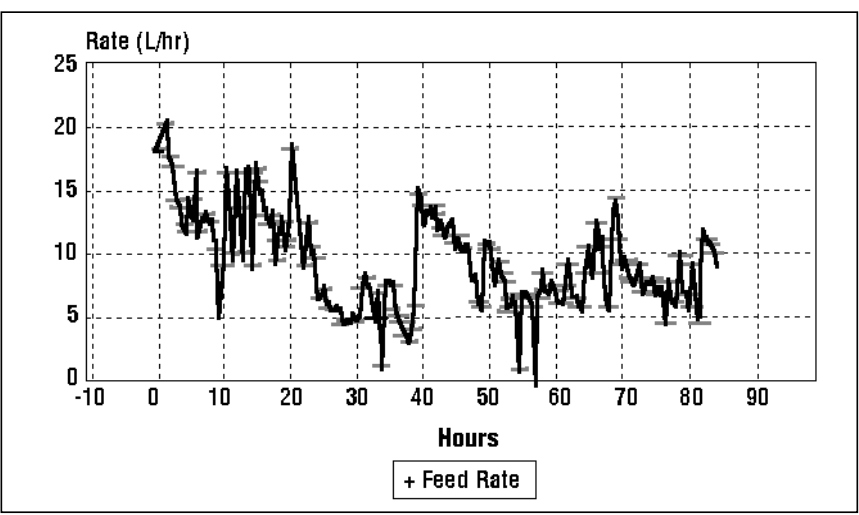

Figure A-2. Feed Rate vs. Time

The frothing due to the oxidizing nature of the feed, over-feeding due to the poor estimation of cold cap coverage, and lack of control on the plenum temperature resulted in a cold cap coverage of over $95 \%$. There were significant events that disrupted the steady state conditions in the melter. The feed rate during the run is shown in Figure A-2. The fluctuation of feed rates between 5 and $15 \mathrm{~L} / \mathrm{hr}$ is clearly indicative of unsteady cold cap behavior and plenum temperature. The feed to the melter was started at a feed rate of $20 \mathrm{~L} / \mathrm{hr}$ and attempts were made to stabilize the feed rate between 10 and $15 \mathrm{~L} / \mathrm{hr}$. Due to the excessive cold cap formation, the feed rate was reduced to between 4 and $7 \mathrm{~L} / \mathrm{hr}$ after 20 hours of operation. This caused a reduction in the cold cap coverage. After 40 hours into the run, the feed rate was again increased to $15 \mathrm{~L} / \mathrm{hr}$ and was then slowly reduced to $5 \mathrm{~L} / \mathrm{hr}$ due to thick cold cap coverage and foaming in the melter. The feed rate was then maintained between 5 and $10 \mathrm{~L} / \mathrm{hr}$ for the last 30 hours of the run.

The excessive cold cap formation is indicated in Figure A-3. Figure A-4 shows the plenum temperature as a function of run hours. An optimum coverage in the melter is represented by the plenum temperature between $525^{\circ}$ and $550^{\circ} \mathrm{C}$. In the run, between 10 to 25 hours and 40 to 45 hours, the plenum temperature was below or around $500^{\circ} \mathrm{C}$, indicating excess coverage of the cold cap.

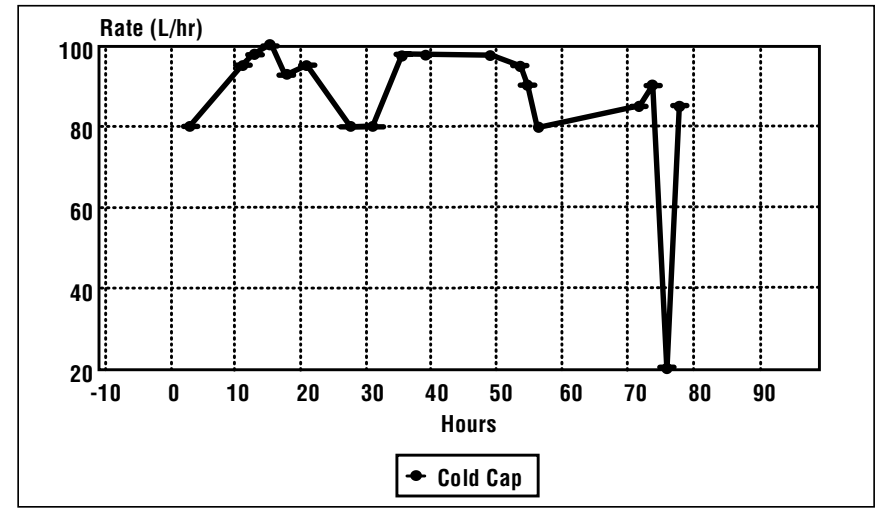

Figure A-3. Percent Cold Cap Coverage vs. Time

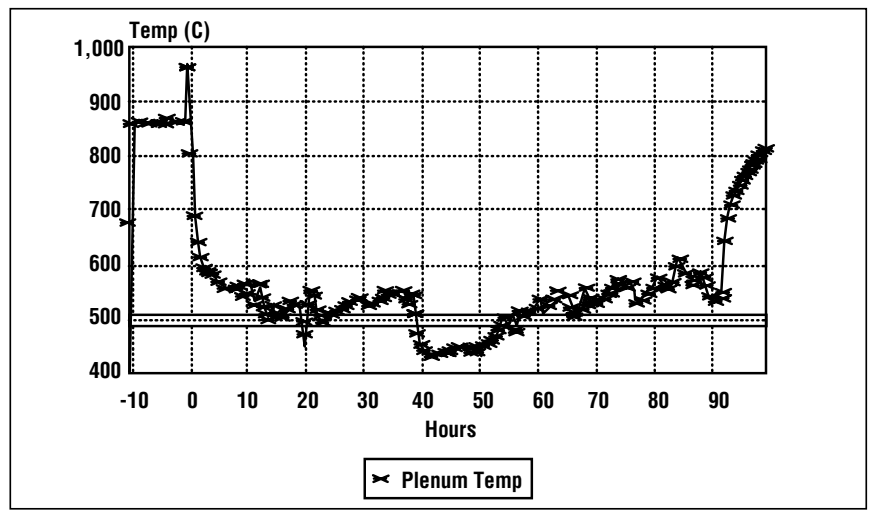

Figure A-4. Plenum Temperature vs. Time 


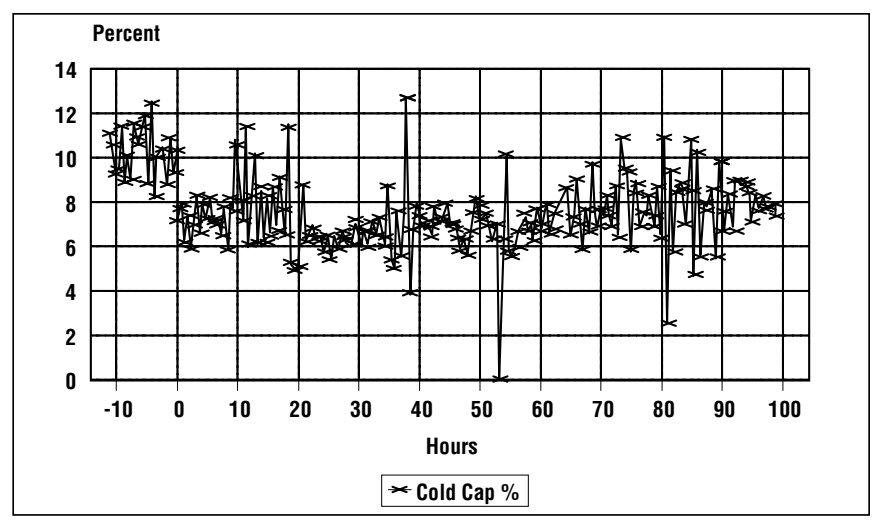

Figure A-5. Melter Power vs. Time

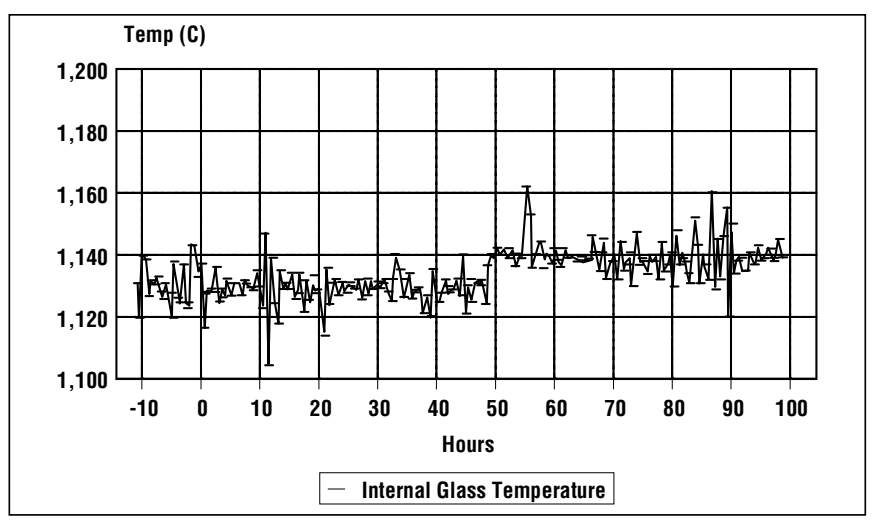

Figure A-6. Internal Glass Pool Temperature vs. Time

Electrode power and internal glass temperatures are shown in Figures A-5 and A-6, respectively. The melter electrode power ranged between 4 and $11 \mathrm{~kW}$. The average electrode power was approximately $7 \mathrm{~kW}$. The internal glass temperature was between $1,120^{\circ}$ and $1,140^{\circ} \mathrm{C}$ during the first 50 hours. A slight increase of about $10^{\circ} \mathrm{C}$ in the internal glass temperature was observed between 50 and 80 hours.

The last 30 hours of data could be considered a representation of the steady state behavior based on: observed variation in the feed rate, plenum temperature, internal glass pool temperature, melter power, and visual inspection of the cold cap. The steady state $\mathrm{Fe}^{+2} / \mathrm{Fe}^{+3}$ ratio in the last 30 hours of the run was 0.02 . Figure A-7 shows the redox model relationship between $\mathrm{Fe}^{+2} / \mathrm{Fe}^{+3}$ and IFO. The data point from this run is plotted on the graph. The data point does not follow the expected relationship between the IFO and the $\mathrm{Fe}^{+2} / \mathrm{Fe}^{+3}$ ratio.

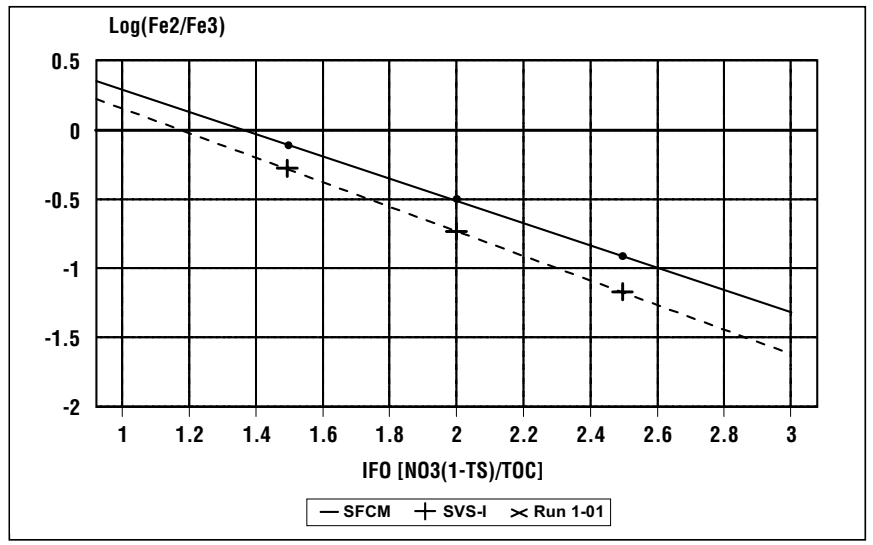

Figure A-7. Redox vs. IFO

\subsection{Summary}

The SVS-III Run 1-01 was started on January 17, 1995 and ended on January 21, 1995. During 83 hours of run time, several key parameters were controlled and changed to optimize the process. The parameters that were of interest included feed rate redox, melter plenum temperature, internal glass pool temperature, melter power, and cold cap formation. Prior to the start of the run, the feed composition was analyzed and attempts were made to verify the composition. The process strategy that was followed for feed verification was similar to the proposed strategy for radioactive operations.

The last 30 hours of data could be considered as representative of steady state behavior based on the observed variation in: feed rate, plenum temperature, glass pool temperature, melter power, and visual inspection of the cold cap. The average $\mathrm{Fe}^{+2} / \mathrm{Fe}^{+3}$ ratio in the last 30 hours of the run was 0.02 and the IFO for Run 1-01 was 2.51. This data point has been included in the Redox Forecasting Model and represents extremely oxidizing conditions in the melt. 
The feed was prepared to target an IFO of 2.28. (The target IFO, after correcting for zirconyl nitrate, was 2.45.) This would have provided an $\mathrm{Fe}^{+2} / \mathrm{Fe}^{+3}$ ratio of 0.20 in the melt. The feed, after analysis, indicated an IFO of 2.53 (The measured IFO after correcting for zirconyl nitrate was 2.69.), and the melter operations process indicated that the feed was oxidizing. The oxidizing nature of the feed is attributed to the fact that the $\mathrm{NO}_{3}$ concentration, as analyzed, has a $10 \%$ measurement error as well as a loss of $\mathrm{NO}_{3}$. These errors are significant enough to result in oxidizing or reducing conditions in the melter during the neutralization reactions between the basic simulant and the acidic glass-former slurry.

The low $\mathrm{pH}$ of 1.15 in the feed is attributed to acid contribution from the zirconyl nitrate solution (containing $21 \%$ nitric acid) that was not accounted for in the $\mathrm{NO}_{3}$ mass balance. This $\mathrm{NO}_{3}$ discrepancy did not impact the sugar calculation because the sugar addition was based on the analyzed $\mathrm{NO}_{3}$ concentration.

In summary, the SVS-III Run 1-01 describes the worst case processing conditions in the melter. These conditions in this run included: low $\mathrm{pH}$ of the feed, high viscosity $\left(84\right.$ poise at $\left.1,100^{\circ} \mathrm{C}\right)$, and a redox ratio of less than 0.02 . 
This page intentionally blank. 


\section{APPENDIX B:}

\subsection{SVS-III RUN 1-01A}

\subsection{Objectives}

SVS-III Run 1-01A concentrated on the following objectives:

- Controlling the redox ratio at approximately 0.20 during steady state melter operations

- Utilizing the heel from Run 1-01 to produce a shimmed batch

- Preparing enough shimmed feed to produce $720 \mathrm{~kg}$ of glass.

\subsection{Feed Preparation and Analysis}

\subsubsection{Chemical Composition}

SVS-III Run 1-01A used the 1,298 L heel left from SVS-III Run 1-01 as the feed batch. Run 1-01A's feed composition is relatively the same as that of Run 1-01 (Appendix A). The chemical composition was analyzed using vitrified feed samples. Based on the chemical analysis, the feed was shimmed by adding the chemicals listed in Table B-1. This shimmed feed was used for Run 1-01A.

Table B-1. Amounts of Shimmed Chemicals

\begin{tabular}{lll}
\multicolumn{1}{c}{ Chemical Formula } & Name & Amount \\
$\mathrm{P}-1200^{\circledR}$ (antifoam) - NOT added due to unavailability & & $1.0 \mathrm{~kg}$ \\
$\mathrm{~B}_{2} \mathrm{O}_{3}$ & Boron Oxide & $17.7 \mathrm{~kg}$ \\
$\mathrm{Fe}(\mathrm{OH})_{3}$ slurry & Ferric Hydroxide slurry & $43.2 \mathrm{~kg}$ \\
$\mathrm{KOH}$ & Potassium Hydroxide & $7.8 \mathrm{~kg}$ \\
$\mathrm{LiOH} * \mathrm{H}_{2} \mathrm{O}$ & Lithium Hydroxide & $11.4 \mathrm{~kg}$ \\
$\mathrm{NaOH}$ & Sodium Hydroxide & $9.6 \mathrm{~kg}$ \\
$\mathrm{SiO}_{2}$ & Silicon Dioxide & $28.9 \mathrm{~kg}$ \\
$\mathrm{ZrO}_{2}$ & Zirconium Dioxide & $2.5 \mathrm{~kg}$ \\
$\mathrm{C}_{12} \mathrm{H}_{22} \mathrm{O}_{11}$ & Sugar & $11.2 \mathrm{~kg}$ \\
\hline
\end{tabular}

After shim chemicals were added to the FHT, a set of 9 feed samples from the FHT were vitrified in the Vitrification Lab for ICP analysis. The ICP analysis is shown in Table B-2. Results indicate that the shimmed feed was within the acceptable processing region. Even though the chemical composition of the feed was acceptable, the feed was analyzed by the ICP using vitrified samples and does not follow the feed make-up strategy for radioactive vitrification operations. The volume of the feed after the shim was 1,373 L. 
Table B-2. ICP Analysis of Vitrified Feed Samples from FHT (weight \% basis)

\begin{tabular}{|c|c|c|c|c|c|c|c|c|c|c|c|c|c|c|}
\hline Wt\% & $\mathbf{a}$ & b & c & d & e & f & $\mathbf{g}$ & h & i & Avg. & $\begin{array}{l}\text { Std. } \\
\text { Dev. }\end{array}$ & $\begin{array}{c}\text { Std. } \\
\text { Dev. } \\
\div \\
\text { Avg. }\end{array}$ & Target & Diff. \\
\hline $\mathrm{I}_{2} \mathrm{O}_{3}$ & 6.24 & 6.28 & 6.48 & 6.41 & 6.49 & 6.22 & 6.11 & 6.11 & 6.13 & 6.28 & 0.14 & 0.02 & 6.00 & -4.59 \\
\hline $\mathbf{B}_{2} \mathrm{O}_{3}$ & 13.08 & 12.84 & 12.88 & 13.25 & 13.08 & 12.84 & 13.20 & 13.18 & 12.54 & 12.99 & 0.22 & 0.02 & 12.89 & -0.76 \\
\hline $\mathrm{CaO}$ & 0.50 & 0.50 & 0.50 & 0.51 & 0.51 & 0.50 & 0.52 & 0.51 & 0.51 & 0.51 & 0.01 & 0.01 & 0.48 & -5.68 \\
\hline $\mathbf{e}_{2} \mathrm{O}_{3}$ & 12.30 & 12.20 & 12.11 & 12.30 & 12.30 & 12.13 & 12.23 & 12.34 & 12.40 & 12.26 & 0.09 & 0.01 & 12.02 & -1.96 \\
\hline $\mathrm{K}_{2} \mathrm{O}$ & 4.71 & 4.75 & 4.77 & 4.83 & 4.79 & 4.97 & 4.83 & 4.77 & 4.61 & 4.78 & 0.09 & 0.02 & 5.00 & 4.35 \\
\hline $\mathbf{L}_{2} \mathbf{O}$ & 3.79 & 3.75 & 3.75 & 3.79 & 3.77 & 3.74 & 3.86 & 3.80 & 3.78 & 3.78 & 0.03 & 0.01 & 3.71 & -1.93 \\
\hline MgO & 0.83 & 0.84 & 0.84 & 0.84 & 0.85 & 0.81 & 0.86 & 0.86 & 0.86 & 0.84 & 0.02 & 0.02 & 0.89 & 5.10 \\
\hline MnO & 0.76 & 0.75 & 0.74 & 0.75 & 0.76 & 0.74 & 0.77 & 0.77 & 0.77 & 0.76 & 0.01 & 0.01 & 0.82 & 7.79 \\
\hline $\mathrm{Na}_{2} \mathrm{O}$ & 8.51 & 8.66 & 8.03 & 8.12 & 8.11 & 8.06 & 8.23 & 8.05 & 7.91 & 8.19 & 0.23 & 0.03 & 8.00 & -2.32 \\
\hline $\mathrm{NiO}$ & 0.23 & 0.22 & 0.23 & 0.22 & 0.23 & 0.22 & 0.23 & 0.23 & 0.23 & 0.23 & 0.00 & 0.02 & 0.25 & 9.28 \\
\hline $\mathbf{P}_{2} \mathrm{O}_{5}$ & 1.16 & 1.09 & 1.12 & 1.10 & 1.13 & 1.09 & 1.13 & 1.14 & 1.17 & 1.13 & 0.03 & 0.02 & 1.20 & 6.15 \\
\hline $\mathrm{SO}_{3}$ & 0.14 & 0.13 & 0.16 & 0.16 & 0.14 & 0.21 & 0.30 & 0.24 & 0.23 & 0.19 & 0.05 & 0.28 & 0.23 & 18.17 \\
\hline $\mathrm{SiO}_{2}$ & 43.05 & 43.34 & 43.73 & 42.94 & 43.14 & 43.56 & 42.86 & 43.12 & 43.82 & 43.28 & 0.33 & 0.01 & 43.15 & -0.31 \\
\hline $\mathrm{TiO}_{2}$ & 0.73 & 0.73 & 0.74 & 0.73 & 0.73 & 0.74 & 0.73 & 0.72 & 0.74 & 0.73 & 0.01 & 0.01 & 0.80 & 8.50 \\
\hline $\mathrm{ZrO}_{2}$ & 3.34 & 3.30 & 3.32 & 3.37 & 3.30 & 3.41 & 3.35 & 3.35 & 3.35 & 3.34 & 0.03 & 0.01 & 3.43 & 2.53 \\
\hline Others & 0.62 & 0.62 & 0.60 & 0.70 & 0.68 & 0.78 & 0.80 & 0.81 & 0.82 & 0.72 & & & 1.11 & \\
\hline Totals & 100.00 & 100.00 & 100.00 & 100.00 & 100.00 & 100.00 & 100.00 & 100.00 & 99.88 & 99.99 & & & 99.98 & \\
\hline
\end{tabular}

\subsubsection{Sugar Adjustments}

The addition of a reducing agent (sugar) was necessary because in Run 1-01 the feed was extremely oxidizing. To determine the amount of sugar, additional tests were performed in the Vitrification Lab. A series of samples were prepared containing different amounts of sugar and the samples were vitrified to determine the $\mathrm{Fe}^{+2} / \mathrm{Fe}^{+3}$ ratio. The data are shown in Table B-3. Based on the analyzed $\mathrm{Fe}^{+2} / \mathrm{Fe}^{+3}$ ratios, a target IFO of 2.28 was selected for the shim. The amount of sugar required for the shim was then scaled to $1,298 \mathrm{~L}$ (density of $1.37 \mathrm{~kg} / \mathrm{L}$ ), and was added to the FHT.

After the shim, another set of feed samples was retrieved from the FHT to determine the $\mathrm{Fe}^{+2} / \mathrm{Fe}^{+3}$ ratio, and the sugar and $\mathrm{NO}_{3}$ concentrations in the final feed. The Vitrification Lab results indicated a Fe $\mathrm{Fe}^{+2} / \mathrm{Fe}^{+3}$ ratio of 0.06 . This $\mathrm{Fe}^{+2} / \mathrm{Fe}^{+3}$ ratio was significantly lower compared to the $\mathrm{Fe}^{+2} / \mathrm{Fe}^{+3}$ ratio of 0.23 expected from the earlier Vitrification Lab tests shown in Table B-3. The oxidizing nature of the feed, despite the sugar addition, could be attributed to the combination of several factors. First, the level and density measurements due to clogging could easily result in erroneous values for the tank volume. Second, the sampling and measurement errors associated with the nitrates and TOC analyses could also result in erroneous $\mathrm{NO}_{3}$ and TOC concentrations. For the $\mathrm{Fe}^{+2} / \mathrm{Fe}^{+3}$ data, $\mathrm{NO}_{3}$ and TOC analyses could be excluded because sugar additions were made on the basis of existing feed and were verified by redox testing. The only factor that could result in oxidizing feed is underestimation of the tank volume. 
Table B-3. Vit Lab Redox Data

\begin{tabular}{cclll}
$\begin{array}{c}\mathbf{N O}_{3} * \\
(\mathbf{p p m})\end{array}$ & $\begin{array}{c}\text { Sugar Heel * } \\
(\mathbf{p p m})\end{array}$ & $\begin{array}{c}\text { Sugar Added } \\
(\mathbf{p p m})\end{array}$ & $\mathbf{I F O}$ & $\mathbf{F e}^{+\mathbf{2}} / \mathbf{F e}^{+\mathbf{3}}$ \\
128,600 & 60,570 & -- & 2.53 & oxidizing \\
128,600 & 60,570 & 3,651 & 2.38 & 0.03 \\
128,600 & 60,570 & 6,302 & 2.28 & 0.23 \\
128,600 & 60,570 & 9,953 & 2.16 & 0.50 \\
\hline
\end{tabular}

*Run 1-01 analysis data

Furthermore, the feed analysis (shown in Table B-4) indicated sugar concentration of $86,450 \mathrm{ppm}$ and $\mathrm{NO}_{3}$ as $118,400 \mathrm{ppm}$. This gave an IFO of 1.63. This is significantly lower than the target IFO of 2.28 . The mass balance indicates $44 \mathrm{~kg}$ of extra sugar in the feed. The samples were reanalyzed with the data also shown in Table B-4. The reanalyzed data show that sugar was within $1 \%$ of the target level in the feed, but the IFO was 2.12. Also note that while the density of the feed did not change during shimming, the nitrate concentration in the analyzed samples dropped $16 \%$. This could be attributed to the destruction of $\mathrm{NO}_{3}$ due to a denitration reaction. If the denitration reactions were occurring, the feed should have been more reducing, based on the IFO of 2.12 (This corresponds to an IFO of 2.45 after correcting for zirconyl nitrate contribution.). The results indicate that the feed is oxidizing. Since the behavior of the feed can not be explained based on denitration reactions, a part of the error is probably due to the measurement uncertainty in the $\mathrm{NO}_{3}$ and $\mathrm{TOC}$ analysis.

Table B-4. Sugar and $\mathrm{NO}_{3}$ Analysis

\begin{tabular}{lllllll} 
Event & $\begin{array}{l}\text { Density } \\
(\mathbf{k g} / \mathbf{L})\end{array}$ & $\begin{array}{l}\mathbf{N O}_{\mathbf{3}} \\
(\mathbf{p p m})\end{array}$ & $\begin{array}{l}\text { Sugar } \\
(\mathbf{p p m})\end{array}$ & Sugar/NO & $\begin{array}{l}\text { Vitrification } \\
\mathbf{L a b} \\
\mathbf{F e}^{+\mathbf{2}} / \mathbf{F e}^{+3}\end{array}$ & $\begin{array}{c}\mathbf{S V S - I I I} \\
\mathbf{F e}^{+2} / \mathbf{F e}^{+3}\end{array}$ \\
$\begin{array}{l}\text { Before shim } \\
\text { (Run 1-01 feed) }\end{array}$ & 1.36 & 128,600 & 60,570 & 0.47 & $<0.01$ & 0.02 \\
Shim FHT & 1.366 & 118,400 & 86,400 & 0.73 & 0.057 & 0.02 \\
Shim MFT* & 1.359 & 108,000 & 59,969 & 0.56 & --- & -- \\
\hline
\end{tabular}

*Reanalysis of shim FHT in the melter feed tank (MFT)

In summary, both uncertainties involved in the level and density measurement in the tanks and the uncertainties involved in $\mathrm{NO}_{3}$ and TOC measurements, have resulted in poor estimation of sugar additions to the feed. The general characteristics for the feed are shown in Table B-5.

Table B-5. Feed Characteristics

$\begin{array}{ll}\text { Parameters } & \text { Amounts } \\ \mathrm{NO}_{3}(\mathrm{ppm}) & 108,000 \\ \mathrm{TOC}(\mathrm{ppm}) & 25,250 \\ \text { Density }(\mathrm{kg} / \mathrm{L}) & 1.36 \\ \% \text { Total Solids (FHT) } & 47.6 \\ \mathrm{pH} & 4.4 \\ \text { Volume FHT (L) } & 1,373 \\ \text { Viscosity of glass @ } 1,100^{\circ} \mathrm{C} \text { (poise) } & 57\end{array}$




\subsection{Melter Operations}

Figure B-1 shows the $\mathrm{Fe}^{+2} / \mathrm{Fe}^{+3}$ ratio as a function of run hours. The data indicate that the feed was fairly oxidizing. Except for the $\mathrm{Fe}^{+2} / \mathrm{Fe}^{+3}$ ratio of 0.03 for the last two airlift samples, the $\mathrm{Fe}^{+2} / \mathrm{Fe}^{+3}$ ratio fluctuated between 0.01 and 0.02 during the run. The $\mathrm{Fe}^{+2} / \mathrm{Fe}^{+3}$ ratio was 0.02 at melter start-up. An average steady state ratio during the entire run was 0.02 . The steady state redox data from this run is plotted on the Redox Forecasting Model curve shown in Figure 18 of Section 5.3.1 (also see Figure B-2). The data point falls below the expected relationship between the IFO and the $\mathrm{Fe}^{+2} / \mathrm{Fe}^{+3}$ ratio.

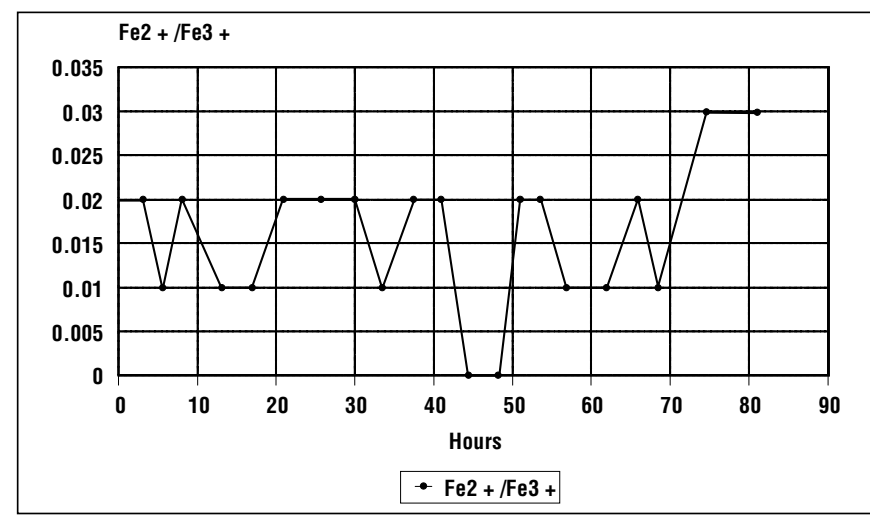

Figure B-1. Redox Ratio vs. Time

Figure B-3 shows the feed rate to the melter as a function of run hours. The feed to the melter was started at a feed rate of $22 \mathrm{~L} / \mathrm{hr}$ and attempts were made to stabilize the rate between 10 and $15 \mathrm{~L} / \mathrm{hr}$. The feed was maintained between 10 and $15 \mathrm{~L} / \mathrm{hr}$ for the first 40 hours of run time. A feed rate was maintained between 13 and $18 \mathrm{~L} / \mathrm{hr}$ for the next 40 hours of the run. The feed rate was increased to maintain the cold cap coverage at greater than $80 \%$. During the run, the feed nozzle clogged several times. The higher-than-normal plenum temperature $\left(600^{\circ} \mathrm{C}\right.$ rather than $525^{\circ} \mathrm{C}$ ), the loss of castable around the feed nozzle, a low cold cap coverage, and various caked solids in the feed (resulting from the boil down) are some of the factors that could have possibly caused clogging in the nozzle.

Figure B-4 shows the melter plenum temperature as a function of run hours. The plenum temperature varied between $550^{\circ}$ and $650^{\circ} \mathrm{C}$. The higher plenum temperature is a result of a small cold cap coverage. The visual estimate of the cold cap coverage is shown

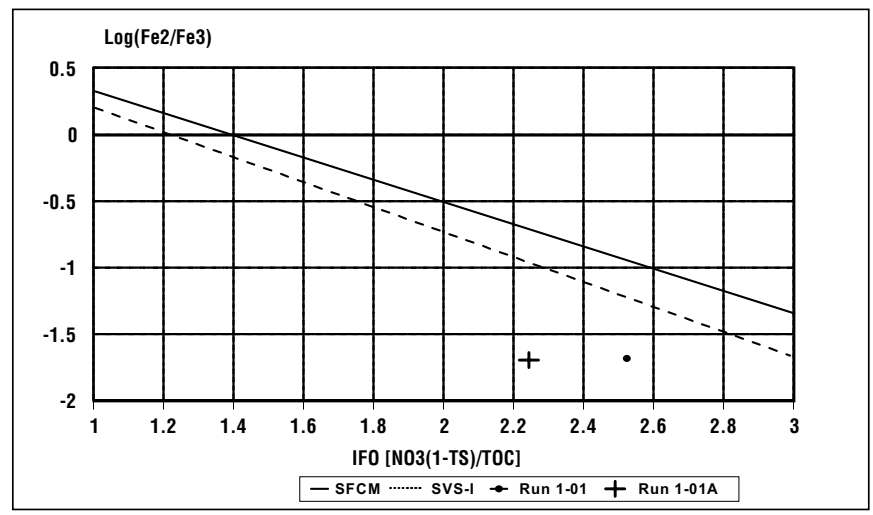

Figure B-2. Redox Ratio vs. IFO

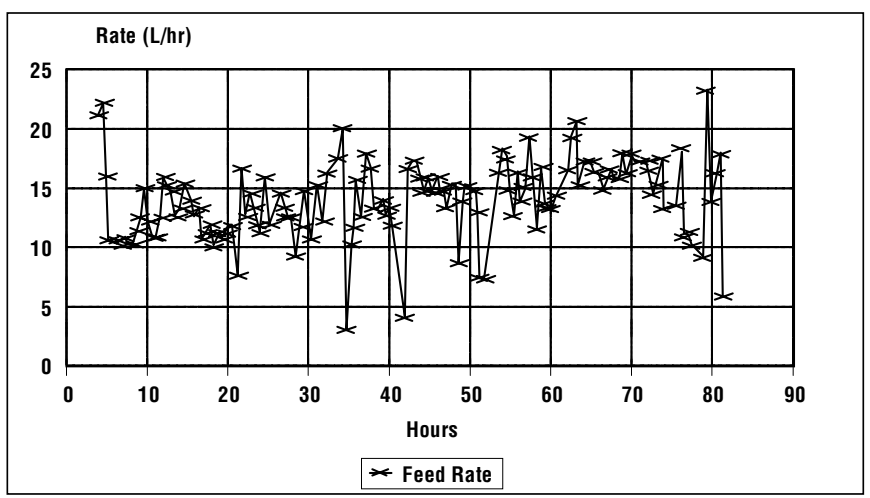

Figure B-3. Feed Rate vs. Time

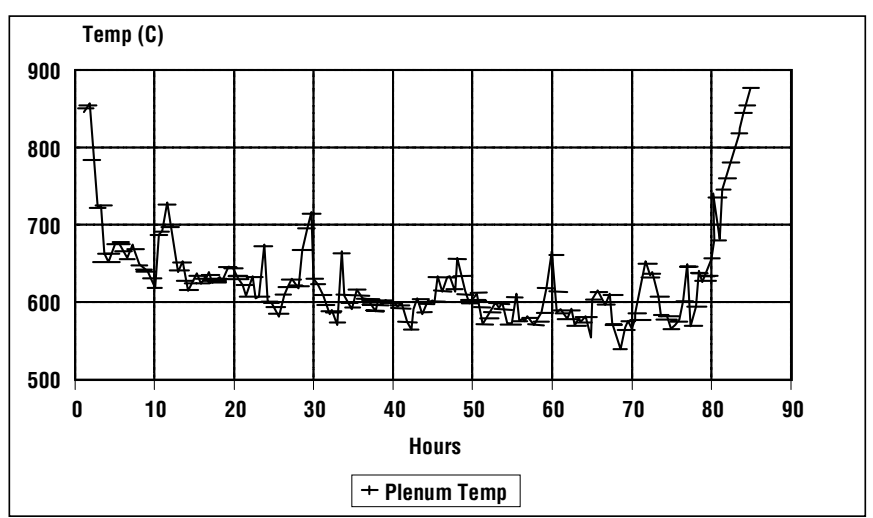

Figure B-4. Plenum Temperature vs. Time 
in Figure B-5. Average cold cap coverage was approximately $60 \%$ during the run. An optimum coverage is approximately $85 \%$ in the melter and is typically represented by a plenum temperature between $525^{\circ}$ and $550^{\circ} \mathrm{C}$. Higher feed rates are avoided due to problems with overfeeding and the formation of excessively thick cold caps.

Figures B-6 and B-7 show the electrode power and the internal glass temperature, respectively, as a function of run hours. The melter electrode power ranged from 7 to $13 \mathrm{~kW}$. The average electrode power was approximately $10 \mathrm{~kW}$.

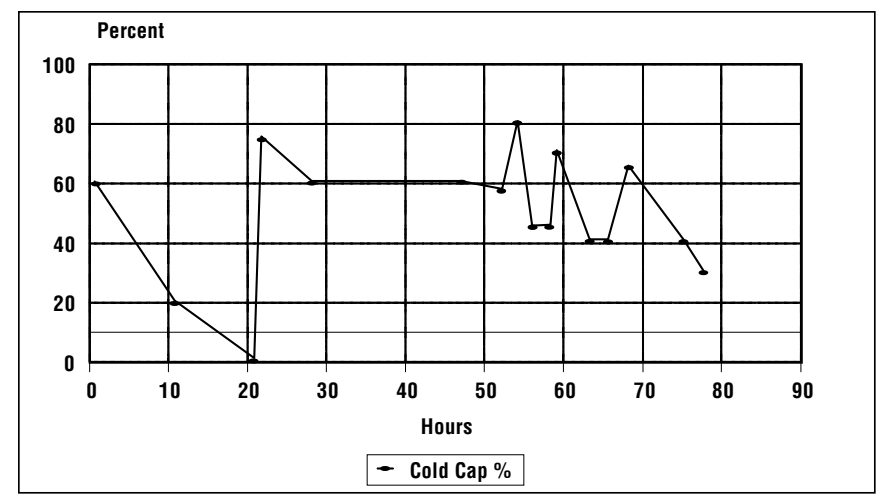

Figure B-5. Percent Cold Cap Coverage vs. Time

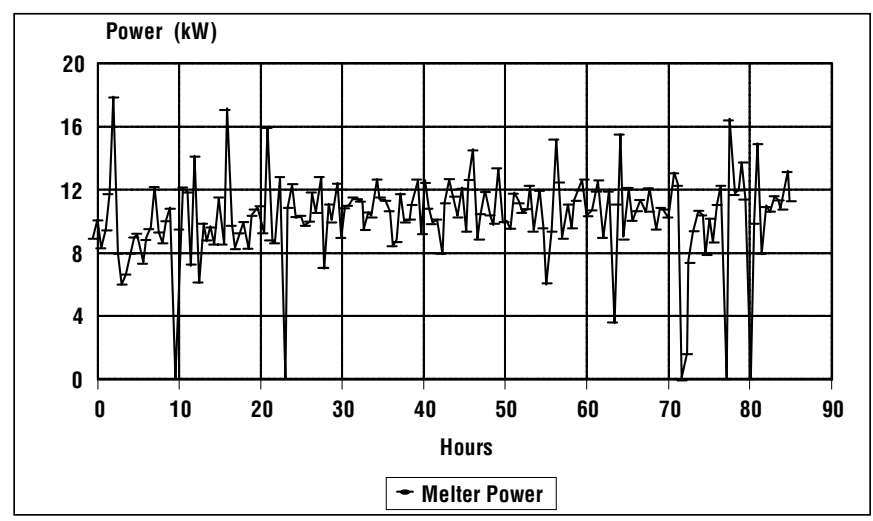

Figure B-6. Melter Power vs. Time

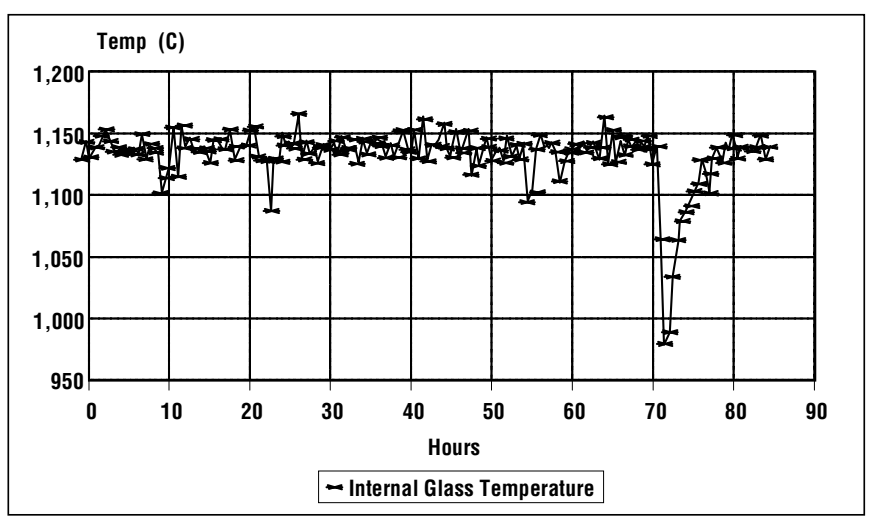

Figure B-7. Internal Glass Pool Temperature vs. Time

The internal glass temperature was between $1,140^{\circ}$ and $1,150^{\circ} \mathrm{C}$. The drop in the internal glass temperature at around 70 hours was due to excess airlift causing the glass level to fall below the thermocouple.

The run concluded on February 2, 1995 due to the failure of the off-gas blower. SVS-III Run 1-01A was conducted for a run time of approximately 82.5 hours.

\subsection{Summary}

SVS-III Run 1-01A started on January 30, 1995 and ended on February 2, 1995. During 82.5 hours of run time, several key parameters were controlled to obtain a steady state redox behavior in the melter. The parameters that were of interest included: slurry feed rate, redox, plenum temperature, internal glass pool temperature, melter power, and cold cap formation.

SVS-III Run 1-01A used the 1,298 L heel left from SVS-III Run 1-01 as the feed batch. Prior to the start of the run, the feed was shimmed to the target Reference 6 glass composition. The shimmed slurry was analyzed using ICP to verify the composition. The chemical analysis of the shimmed slurry, based on the ICP analysis of the vitrified slurry samples, indicated that the composition was within the processing regime as defined in the Waste Form Qualification Report (WQR), Sections 1.1 and 1.3. 
The feed was shimmed to target an IFO of 2.28. (An IFO of 2.45 after correction for zirconyl nitrate contribution.) This would have provided an $\mathrm{Fe}^{+2} / \mathrm{Fe}^{+3}$ ratio of 0.20 in the melt. The redox analysis after the shim, using crucible tests, indicated an $\mathrm{Fe}^{+2} / \mathrm{Fe}^{+3}$ ratio of 0.06 . The oxidizing nature of the feed, despite sugar addition to target an IFO of 2.28, could be attributed to the erroneous measurement of the tank volume due to the clogging of the level and density probes in the FHT. Also, the feed analysis after verification indicated an IFO of 2.12. This is in contrast to the observed oxidizing behavior of the feed and is probably attributed to the measurement uncertainty in the $\mathrm{NO}_{3}$ and TOC analysis. Both the uncertainties involved in the level and density measurement (due to clogging) in the tanks and the uncertainties involved in $\mathrm{NO}_{3}$ and TOC measurements, have resulted in poor estimation of sugar additions to the feed.

Run 1-01A used the $\mathrm{Fe}^{+2} / \mathrm{Fe}^{+3}$ ratio of 0.02 as the steady state value and an IFO of 2.28 for the Redox Forecasting Model. Due to the uncertainties in the $\mathrm{NO}_{3}$ and TOC analysis, the data point falls below the expected relationship between the IFO and the $\mathrm{Fe}^{+2} / \mathrm{Fe}^{+3}$ ratio. This data point represents extremely oxidizing conditions in the melt similar to Run 1-01.

During the entire run, attempts were made to maintain steady state conditions based on: feed rate, plenum temperature, redox conditions, internal glass pool temperature, melter power, and visual inspection of the cold cap. The overall performance of the melter was significantly improved compared to Run 1-01.

In summary, Run 1-01A describes oxidizing processing conditions similar to Run 1-01 in the melter, but the overall performance was much better than Run 1-01. 


\section{APPENDIX C:}

\subsection{SVS-III RUN 1-03}

\subsection{Objectives}

SVS-III Run 1-03 concentrated on the following objectives:

- Defining and testing the feed make-up strategy for radioactive operations

- Preparing enough feed to produce $720 \mathrm{~kg}$ of glass.

\subsection{Feed Preparation}

The feed preparation process for Run 1-03 of the SVS-III testing did not include heel simulation. This allowed the run to proceed with batch preparation and composition verification based on the actual weights of the chemicals added during feed preparation. The simulant and glass-formers were prepared to yield a total of $720 \mathrm{~kg}$ of glass. The batch formulations were based on the Reference 6 target glass composition. The amounts of simulant and glass-former chemicals that were added to prepare the batch were similar (See Section 4) to previous runs. The chemicals were added in the sequence shown in Tables 3 and 4 . Table C-1 shows the analyzed composition of the simulant, glass-formers, and final slurry. The analyzed composition for the simulant shows significant variance. The glass-formers indicate that the analysis of $\mathrm{MnO}, \mathrm{MgO}$, and $\mathrm{K}_{2} \mathrm{O}$ are problematic. The final slurry shows that the analyzed $\mathrm{Al}_{2} \mathrm{O}_{3}, \mathrm{MgO}, \mathrm{TiO}_{2}$, and $\mathrm{K}_{2} \mathrm{O}$ are outside the acceptable range for the final composition for the slurry.

The simulant was first prepared in the slurry mix tank (SMT) and then transferred to the feed hold tank (FHT). The glass-formers were then prepared in the SMT. The volume of the simulant and the glass-former slurries were 929 and $948 \mathrm{~L}$, respectively. Next, the simulant was concentrated by boiling it in the FHT to a volume of $822 \mathrm{~L}$. After concentration, the glass-formers from the SMT were transferred to the FHT. When the glass-formers are transferred to the concentrated simulant, the $\mathrm{HNO}_{3}$ in the glass-formers reacts with the $\mathrm{NaNO}_{2}$ to generate $\mathrm{NO}$ by the following set of reactions:

$$
\begin{aligned}
& \mathrm{NaNO}_{2}+\mathrm{HNO}_{3} \rightarrow \mathrm{NaNO}_{3}+\mathrm{HNO}_{2} \\
& 3 \mathrm{HNO}_{2} \rightarrow \mathrm{H}^{+}+\mathrm{NO}_{3}^{-}+2 \mathrm{NO}+\mathrm{H}_{2} \mathrm{O}
\end{aligned}
$$

The total amount of $\mathrm{NO}_{3}$ lost as a result of this reaction during the transfer, was approximately $2.7 \mathrm{~kg}$. This amount was estimated from the $\mathrm{NO}_{3}$ measurements during transfer. The combined volume of the simulant and glass-former slurry was $1,768 \mathrm{~L}$. 
Table C-1. Analyzed Composition of the Slurries

\begin{tabular}{|c|c|c|c|c|c|c|c|c|c|}
\hline & $\begin{array}{c}\text { Target } \\
\text { Glass } \\
\text { (kg) }\end{array}$ & $\begin{array}{c}\text { Target } \\
\text { Simulant } \\
\quad(k g)\end{array}$ & $\begin{array}{c}\text { Analyzed } \\
\text { Simulant } \\
\quad(k g)\end{array}$ & $\begin{array}{c}\text { Percent } \\
\text { Difference }\end{array}$ & $\begin{array}{c}\text { Target } \\
\text { Formers } \\
\text { (kg) }\end{array}$ & $\begin{array}{c}\text { Analyzed } \\
\text { Formers } \\
(\mathbf{k g})\end{array}$ & $\begin{array}{c}\text { Percent } \\
\text { Difference }\end{array}$ & $\begin{array}{c}\text { Analyzed } \\
\text { Slurry } \\
(\mathbf{k g})\end{array}$ & $\begin{array}{c}\text { Percent } \\
\text { Difference }\end{array}$ \\
\hline $\mathrm{Al}_{2} \mathbf{O}_{3}$ & 43.20 & 22.39 & 20.19 & -9.8 & 20.81 & 20.26 & 2.6 & 36.88 & 14.6 \\
\hline $\mathbf{B}_{2} \mathbf{O}_{3}$ & 92.81 & 0.43 & 2.07 & 378.3 & 92.38 & 89.67 & 2.9 & 89.62 & 3.4 \\
\hline $\mathrm{CaO}$ & 3.46 & 3.46 & 4.58 & 32.7 & & & & 3.92 & -13.3 \\
\hline $\mathrm{Fe}_{2} \mathrm{O}_{3}$ & 86.54 & 86.54 & 99.60 & 15.1 & & 2.93 & err & 89.25 & -3.1 \\
\hline $\mathrm{K}_{2} \mathrm{O}$ & 36.00 & 29.30 & 27.59 & -5.8 & 6.70 & 7.73 & -15.5 & 29.62 & 17.7 \\
\hline $\mathbf{L i}_{2} \mathbf{O}$ & 26.71 & 0.00 & 0.25 & err & 26.71 & 29.20 & -9.3 & 27.73 & -3.8 \\
\hline MgO & 6.41 & 1.30 & 1.19 & -8.1 & 5.11 & 2.42 & 52.7 & 5.16 & 19.4 \\
\hline MnO & 5.90 & 4.10 & 4.81 & 17.3 & 1.80 & 2.18 & -21.1 & 5.88 & 0.5 \\
\hline $\mathrm{Na}_{2} \mathrm{O}$ & 57.60 & 36.00 & 40.73 & 13.1 & 21.60 & 22.94 & -6.2 & 57.72 & -0.2 \\
\hline $\mathbf{P}_{2} \mathbf{O}_{5}$ & 8.64 & 8.64 & 9.73 & 12.6 & & 0.47 & & 8.71 & -0.8 \\
\hline $\mathrm{SO}_{3}$ & 1.66 & 1.66 & 3.38 & 104.0 & & 1.02 & err & 3.78 & -128.4 \\
\hline $\mathrm{SiO}_{2}$ & 310.68 & 82.94 & 104.18 & 25.6 & 227.16 & 235.82 & -3.8 & 322.20 & -3.7 \\
\hline $\mathrm{TiO}_{2}$ & 5.76 & 2.88 & 2.16 & -24.9 & 2.88 & 2.80 & 2.9 & 4.66 & 19.1 \\
\hline $\mathrm{ZrO}_{2}$ & 24.70 & 15.34 & 17.38 & 13.3 & 9.29 & 10.53 & -13.4 & 25.56 & -3.5 \\
\hline Others & 8.79 & 9.22 & 7.46 & & 0.00 & 0.00 & & 4.41 & \\
\hline Total & 718.85 & 304.20 & 345.32 & & 414.43 & 427.97 & & 715.09 & \\
\hline
\end{tabular}

Reductant addition was based on the actual additions of nitrates and nitrites to the slurry and the Vitrification $\mathrm{Lab}$ redox tests. Table $\mathrm{C}-2$ shows the sources of $\mathrm{NO}_{3}$ and their contributions to the feed. The total amount of $\mathrm{NO}_{3}$ and $\mathrm{NO}_{2}$ present in the feed was $314.6 \mathrm{~kg}$. This includes the loss of $\mathrm{NO}_{3}$ during transfer based on the above reactions.

A series of samples containing varying amounts of sugar to target the different IFOs, were prepared. The calculations for the IFO were based on the following relationship:

$$
\mathrm{IFO}=\mathrm{NO}_{3}(1-\mathrm{TS}) / \mathrm{TOC}
$$

where $\mathrm{NO}_{3}$ is the nitrate concentration, TS is the fraction of total solids, and TOC is the total organic carbon. For Run 1-03, the samples shown in Table C-3 were vitrified using a Direct Slurry Redox Test (DSRT) and analyzed for $\mathrm{Fe}^{+2} / \mathrm{Fe}^{+3}$. Based on the Redox Forecasting Model, an IFO of 2.6 was selected as a target for this run. The DSRT indicated the IFO of 2.67 corresponded to a $\mathrm{Fe}^{+2} / \mathrm{Fe}^{+3}$ ratio of 0.24 . Since the crucible tests were designed to be more reducing than the slurry-fed ceramic melter (SFCM) or SVS-I, the IFO of 2.67 would attain a Fe $\mathrm{Fe}^{+2} / \mathrm{Fe}^{+3}$ ratio of 0.1 in SVS-III. The IFO of 2.67 corresponds to an IFO of 2.90 after correcting for the zirconyl nitrate contributions. Based on this assumption, $142 \mathrm{~kg}$ of sugar was added to the FHT. A DSRT on the post-sugar sample indicated a Fe $\mathrm{Fe}^{+2}$ ratio of 0.05 . The difference in the $\mathrm{Fe}^{+2} / \mathrm{Fe}^{+3}$ response due to sugar addition in the Vitrification Lab sample that uses a 250 gm batch, and the SVS-III batch which is approximately $2,400 \mathrm{~kg}$, could be attributed to the volume and density errors in calculating the additions. The FHT slurry was further shimmed with $2.3 \mathrm{~kg}$ of sugar, providing an $\mathrm{Fe}^{+2} / \mathrm{Fe}^{+3}$ ratio of 0.18 using a DSRT. The final volume of the slurry after sugar addition was $1,859 \mathrm{~L}$. 
Table C-2. Nitrate Balance

\begin{tabular}{llll} 
Nitrate Balance & Simulant $(\mathbf{k g})$ & Glass-Former $(\mathbf{k g})$ & Slurry $(\mathbf{k g})$ \\
Nitric Acid $(35 \%)$ & 0.00 & 707.50 & 707.50 \\
Sodium Nitrate & 16.78 & 0.00 & 16.78 \\
Sodium Nitrite & 25.92 & 0.00 & 25.92 \\
Zirconyl Nitrate & 78.28 & 47.40 & 125.68 \\
\hline Total $\mathrm{NO}_{2}$ & 17.28 & & $\mathrm{NO}_{3}(\mathrm{~kg})$ \\
\hline & $\mathrm{NO}_{3}(\mathrm{~kg})$ & $\mathrm{NO}_{3}(\mathrm{~kg})$ & 243.69 \\
Nitric $\mathrm{Acid}$ & 0.00 & 243.69 & 12.24 \\
Sodium Nitrate & 12.24 & 0.00 & 7.75 \\
Sodium Nitrite & 7.75 & 0.00 & \\
Zirconyl Nitrate & & & 50.88 \\
$(42.5 \%$ zirconyl nitrate & & 19.19 & 314.57 \\
in $\left.21.1 \% \mathrm{HNO}_{3}\right)$ & 31.69 & 262.89 & \\
\hline Total $\mathrm{NO}_{3}$ & 51.68 & & \\
\hline
\end{tabular}

Table C-3. DSRT on 'Sugared' Feed

\begin{tabular}{llll} 
IFO & $\begin{array}{l}\text { Sugar } \\
(\mathbf{2 5 0} \text { g batch })\end{array}$ & $\mathbf{N O}_{\mathbf{3}} / \mathbf{T O C}$ & $\mathbf{F e}^{+2} / \mathbf{F e}^{+3}$ \\
2.71 & 14.75 & 5.31 & 0.10 \\
2.67 & 15.00 & 5.22 & 0.24 \\
2.54 & 15.76 & 4.97 & 0.61 \\
2.38 & 16.82 & 4.66 & 1.04 \\
2.20 & 18.19 & 4.31 & 1.49 \\
\hline
\end{tabular}

Table C-4 shows the measured $\mathrm{NO}_{3}, \mathrm{NO}_{2}, \mathrm{TOC}, \mathrm{pH}, \% \mathrm{TS}$, and density for the simulant, glass-formers, and pre- and post-sugar slurries. The final slurry had an oxide loading of $378 \mathrm{~g} / \mathrm{L}$, compared to the theoretical oxide loading of $387 \mathrm{~g} / \mathrm{Ll}$. The density of the final slurry was $1.35 \mathrm{~kg} / \mathrm{L}$, and the $\mathrm{pH}$ was 2.8 . The density as measured by the Vitrification Lab, A\&PC Lab, and level probes in the SMT and FHT were similar. Both the TOC and $\mathrm{NO}_{3}$ indicated deviation from the target levels. 
Table C-4. Slurry Properties

\begin{tabular}{|c|c|c|c|c|c|c|c|c|}
\hline Slurry & pH & $\begin{array}{l}\text { Density } \\
(\mathrm{kg} / \mathrm{L})\end{array}$ & $\begin{array}{l}\text { Volume } \\
\text { (L) }\end{array}$ & $\begin{array}{l}\mathrm{NO}_{3} \\
(\mathrm{~kg})\end{array}$ & $\begin{array}{l}\mathrm{NO}_{2} \\
(\mathrm{~kg})\end{array}$ & $\begin{array}{l}\text { TOC } \\
\text { (kg) }\end{array}$ & $\% \mathrm{TS}$ & $\begin{array}{l}\text { Oxide } \\
(\mathrm{g} / \mathrm{L})\end{array}$ \\
\hline $\begin{array}{l}\text { Pre-boil } \\
\text { Simulant }\end{array}$ & 11.2 & $1.23(\mathrm{~V})$ & 929 & $\begin{array}{l}31.6 \\
(43.9)\end{array}$ & $\begin{array}{l}17.3 \\
(17.3)\end{array}$ & & 34.1 & 339.4 \\
\hline $\begin{array}{l}\text { Post-boil } \\
\text { Simulant }\end{array}$ & 11.4 & $1.28(\mathrm{~V})$ & 822 & & & & 38.5 & 398.5 \\
\hline $\begin{array}{l}\text { Glass- } \\
\text { formers }\end{array}$ & $<<1$ & $\begin{array}{l}1.43(\mathrm{~L}) \\
1.43(\mathrm{~V}) \\
1.43(\mathrm{~A})\end{array}$ & 948 & $\begin{array}{l}277.6 \\
(262.9)\end{array}$ & & & 53 & \\
\hline Pre-sugar & 3.0 & $\begin{array}{l}1.35(\mathrm{~L}) \\
1.36(\mathrm{~V})\end{array}$ & 1,768 & $\begin{array}{l}285.6 \\
(314.6)\end{array}$ & & & & 425.2 \\
\hline Post-sugar & $\begin{array}{l}2.9(\mathrm{~V}) \\
2.8(\mathrm{~A})\end{array}$ & $\begin{array}{l}1.34(\mathrm{~L}) \\
1.35(\mathrm{~V}) \\
1.36(\mathrm{~A})\end{array}$ & 1,859 & $\begin{array}{l}296 \\
(314.6)\end{array}$ & & $\begin{array}{l}66.1 \\
(59.8)\end{array}$ & 49.1 & 378.8 \\
\hline $\begin{array}{l}\text { Post-sugar } \\
\text { (Shim of } \\
2 \mathrm{~kg} \text { added) }\end{array}$ & $2.8(\mathrm{~V})$ & & & $\begin{array}{l}276.1 \\
(314.6)\end{array}$ & & $\begin{array}{l}60.3 \\
(60.8)\end{array}$ & 49.0 & \\
\hline $\begin{array}{l}\text { Post-sugar } \\
\text { (Shim II of } \\
1.6 \mathrm{~kg} \text { added) }\end{array}$ & & & & & & & & \\
\hline
\end{tabular}

(A) A\&PC Lab, (V) Vitrification Lab, (L) Level Probes, ( ) Target Amounts

\section{C.3 Melter Operations}

Run 1-03 started on February 27, 1995 and ended on March 3, 1995. The melter was continuously operated for 111 hours. During the run, several key parameters were controlled and monitored to attain steady state in the melter. The parameters of interest included: feed rate, redox, melter plenum temperature, internal glass pool temperature, melter power, and cold cap coverage.

The entire run could be divided into three segments. The first 30 to 35 hours of operation represent attainment of steady cold cap and plenum temperature in the melter. The second segment is characterized by steady state behavior and is represented between 30 and 90 hours. The final segment, representing the last 24 hours, indicates melter behavior after additional sugar was introduced to the feed. The sugar shim of $1.6 \mathrm{~kg}$ was made to evaluate the redox response in the melter due to higher TOC.

The most important quantitative parameter that dictates the attainment of the steady state is the plenum temperature. The feed rate is controlled to maintain plenum temperature within the target range. The target range for Run 1-03 was defined between $500^{\circ}$ and $550^{\circ} \mathrm{C}$. Figure $\mathrm{C}-1$ shows the plenum temperature as a function of run time. At the start of the run, the plenum temperature was approximately $950^{\circ} \mathrm{C}$. An initially high feed rate $(30 \mathrm{~L} / \mathrm{hr})$

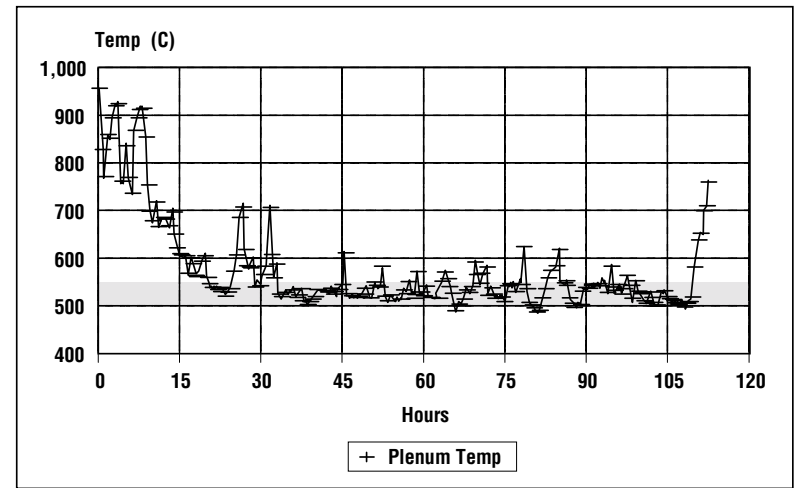

Figure C-1. Plenum Temperature vs. Time 
was used to attain a stable cold cap in the melter and reduce the plenum temperature to $525^{\circ} \mathrm{C}$. The plenum temperature was stabilized around $525^{\circ} \mathrm{C}$ within 30 hours of operation. During the steady state, between 30 and 90 hours, the plenum temperature was maintained between $500^{\circ}$ and $550^{\circ} \mathrm{C}$. The average plenum temperature was $525^{\circ} \mathrm{C}$. The plenum temperature did not change during the last 24 hours of operation, representing the sugar shim.

Figure $\mathrm{C}-2$ shows the $\mathrm{Fe}^{+2} / \mathrm{Fe}^{+3}$ ratio as a function of run hours. The $\mathrm{Fe}^{+2} / \mathrm{Fe}^{+3}$ ratio varied between 0.01 and 0.05 . In the steady state region, the average $\mathrm{Fe}^{+2} / \mathrm{Fe}^{+3}$ ratio was 0.02 . The variation in $\mathrm{Fe}^{+2} / \mathrm{Fe}^{+3}$ data is a combination of temperature, composition, and cold cap fluctuations within the melter, and measurement errors associated with the $\mathrm{Fe}^{+2} / \mathrm{Fe}^{+3}$ analysis. The sugar shim indicated an increase in the $\mathrm{Fe}^{+2} / \mathrm{Fe}^{+3}$ ratio. The last $\mathrm{Fe}^{+2} / \mathrm{Fe}^{+3}$ ratio before the conclusion of the run was 0.08 , and was increasing based on the preceding airlift samples. The steady state data indicates that the feed was tending towards the oxidizing end of the Redox Forecasting Model (Figure C-3). The data also indicate that the steady state redox ratio is much more oxidizing than the SVS-I or the SFCM. The major differences in the feed chemistry between the SVS-III and the past FACTS and SVS-I tests are the use noble metals and nitrate salts $\left(\mathrm{NaNO}_{2}\right.$ and $\left.\mathrm{NaNO}_{3}\right)$.

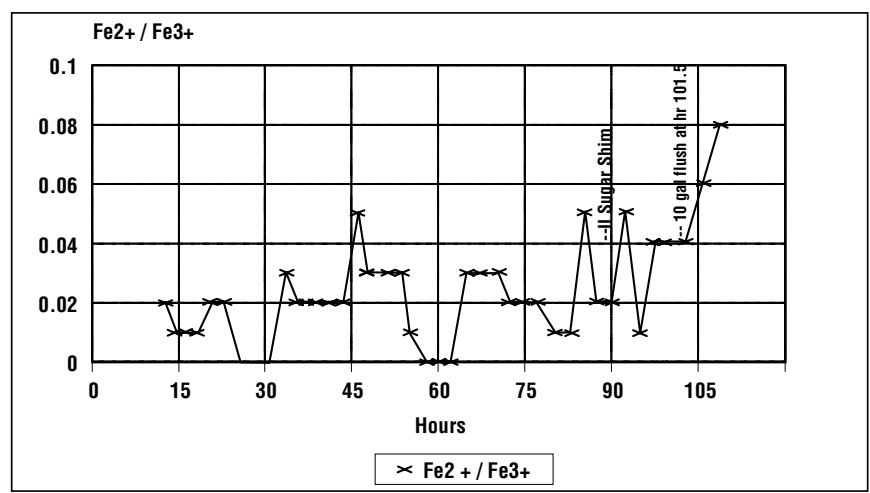

Figure C-2. Redox Ratio vs. Time

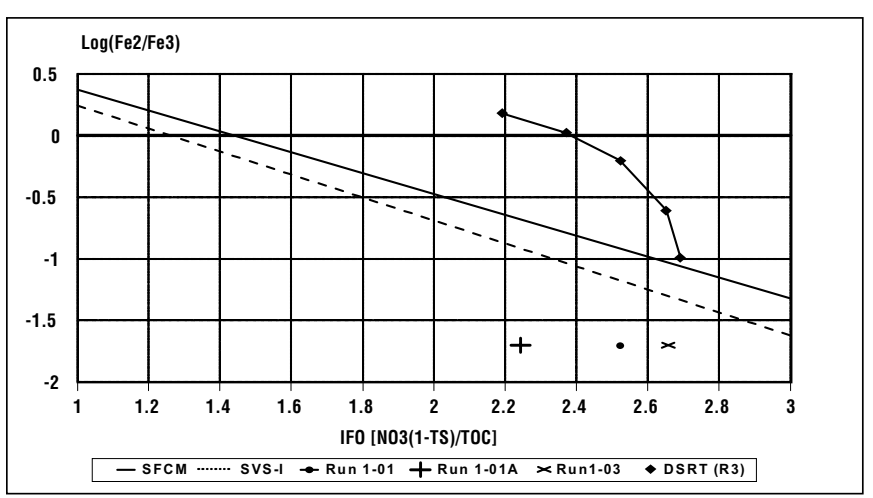

Figure C-3. Redox Forecasting Model (Redox vs. IFO)

Also, both SVS-I and the SFCM were not operated under such extremely oxidizing conditions and the possibility exists that the linear relationship between the IFO and the $\mathrm{Fe}^{+2} / \mathrm{Fe}^{+3}$ ratio may not be applicable under such conditions.

Figure C-4 shows the qualitative estimate of the visual observations of the cold cap coverage. In the steady state region, the cold cap coverage was maintained between 80 and $95 \%$. The cold cap coverage was within the expected range during the run.

The feed rate during the run is shown in Figure C-5. The feed rate data was collected every 30 minutes and is plotted as the actual amount of feed fed to the melter in each 30 minute interval. This excludes the interruptions resulting due to the plugging of the feed nozzle or the off-gas lines. Again, in the steady state region, the feed rate was maintained between 15 and $20 \mathrm{~L} / \mathrm{hr}$. This range provided a stable cold cap with a coverage of $85 \%$ or more and a plenum temperature between $500^{\circ}$ and $550^{\circ} \mathrm{C}$.
Figure C-4. Percent Cold Cap Coverage vs. Time

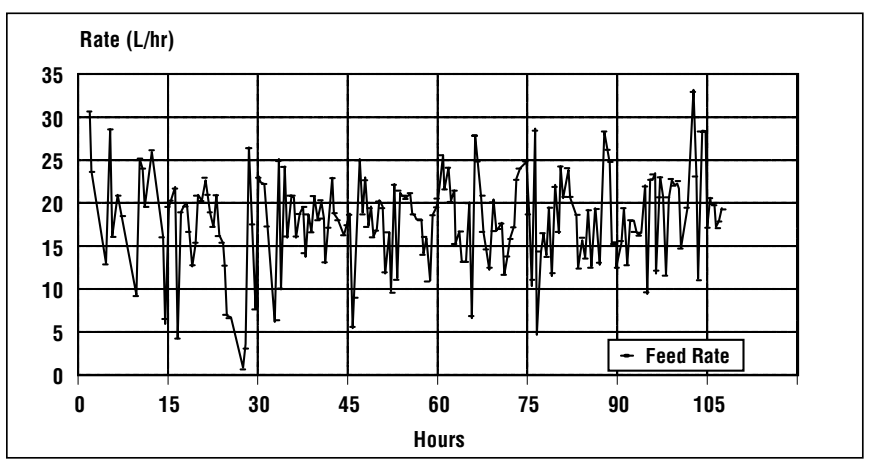

Figure C-5. Feed Rate vs. Time

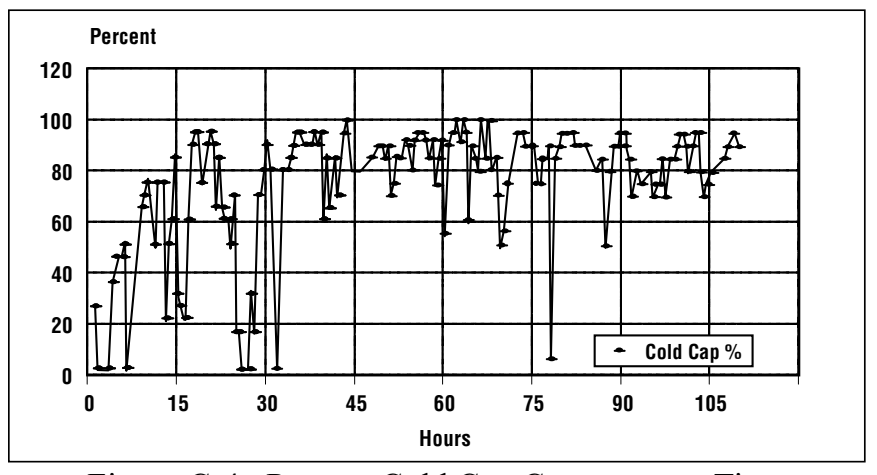


Figures C-6 and C-7 show the electrode power and the internal glass temperature, respectively. The melter electrode power was maintained between 7 and $13 \mathrm{~kW}$. The average electrode power was approximately 10 $\mathrm{kW}$. The internal glass temperature was between $1,125^{\circ}$ and $115^{\circ} \mathrm{C}$ during the run. The average internal glass temperature was $1,140^{\circ} \mathrm{C}$. Both the electrode power and the internal glass temperature behavior indicates that the melter operating conditions did not change during the run.

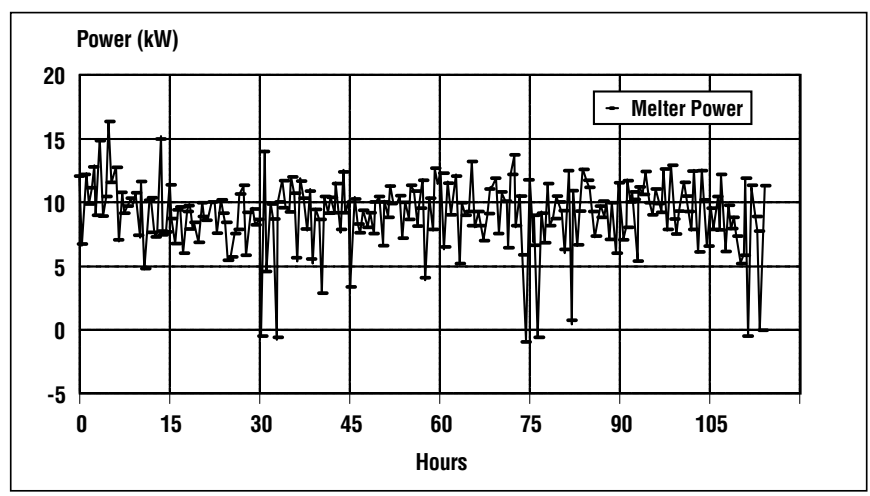

Figure C-6. Melter Power vs. Time

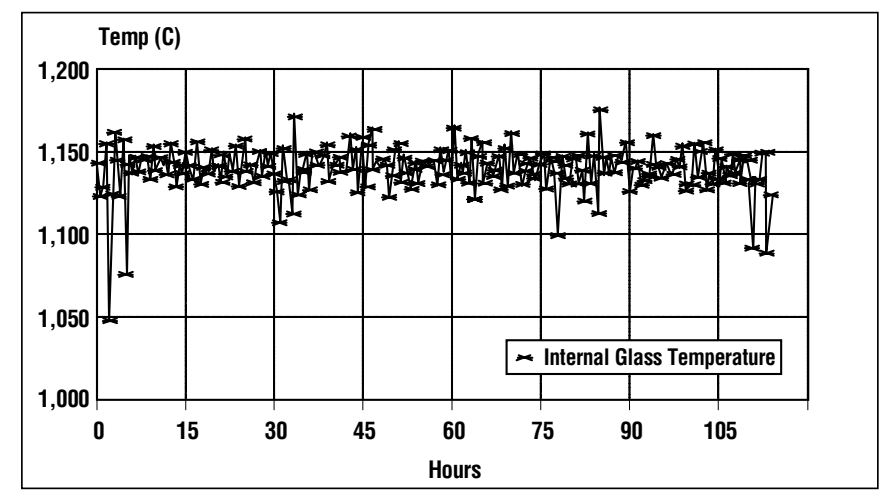

Figure C-7. Internal Glass Pool Temperature vs. Time

\subsection{Summary}

The SVS-III system takes about 35 hours to attain steady state conditions. This assessment is based on the observed variation in the feed rate, plenum temperature, and visual inspection of the cold cap. The steady state average $\mathrm{Fe}^{+2} / \mathrm{Fe}^{+3}$ ratio during the run was 0.02 . This response is based on an IFO of 2.64. This corresponds to an IFO of 2.90 after correcting for zirconyl nitrate contributions. This run provides a data point towards the oxidizing end of the Redox Forecasting Model. Run 1-03 represents the most successful run in the first series of the SVS-III testing program. All the required parameters were controlled and operated within the prescribed range. 


\section{APPENDIX D:}

\subsection{SVS-III RUNS 1-04 AND 1-04'}

\subsection{Objectives}

SVS-III Runs 1-04 and 1-04' concentrated on the following objectives:

- Targeting a redox ratio of 0.2

- Preparing enough feed to produce $720 \mathrm{~kg}$ of glass.

(Note: Test Run 1-04 is presented in two parts: The first part, Run 1-04, extends from start-up to the feed shutdown. The second part, Run 1-04', covers the post-acid shim portion of the run.)

\subsection{Feed Preparation for Part I (Run 1-04)}

The raw materials' calculations for the melter feed are targeting an 1,800 L slurry batch to produce $720 \mathrm{~kg}$ of glass. The target $\mathrm{Fe}^{+2} / \mathrm{Fe}^{+3}$ ratio for Run 1-04 was 0.2. To achieve this ratio in the feed slurry, the total amount of nitrates was reduced by $10 \mathrm{~kg}$, targeting a $\mathrm{pH}$ of $\sim 4$ in the final feed, and the amount of sugar was increased by $23 \mathrm{~kg}$ relative to Run 1-03. Based on the Redox Forecasting Model previously shown in Figure 18 of Section 5.3.1, Vitrification Lab slurry melts, and data from SVS-III Run 1-03, the IFO selected for Run 1-04 was 2.25; this is 0.39 lower than the IFO for Run 1-03. This IFO corresponds to a $\mathrm{Fe}^{+2} / \mathrm{Fe}^{+3}$ ratio of 0.2 for the SVS-III melter using the SVS-I relationship. When Run 1-04 was suspended the $\mathrm{Fe}^{+2} / \mathrm{Fe}^{+3}$ ratio was 0.93 .

The waste simulant recipe for Run 1-04 is similar to previous runs. The SMT volume measured by the level probe after the waste simulant chemical additions was $1,426 \mathrm{~L}$ with a density of $1.25 \mathrm{~kg} / \mathrm{L}$. The high volume is due to a greater-than-usual amount $(539 \mathrm{~L})$ of flush water added to the SMT. There were no other apparent problems with the waste simulant make-up.

The glass-former recipe for Run 1-04 is also similar to previous runs. The chemicals were added in the order shown in Tables 3 and 4. The SMT volume, as measured by the level probe after the glass-former chemical additions, was $920 \mathrm{~L}$ with a density of $1.42 \mathrm{~kg} / \mathrm{L}$. There were no apparent problems with the glass-former make-up.

The waste simulant chemicals were added to the SMT, transferred to the FHT, and then boiled down from 1,418 to $988 \mathrm{~L}$. The glass-formers were then added to the SMT. As the glass-formers were transferred from the SMT to the FHT and added to the concentrated waste simulant, the $\mathrm{HNO}_{3}$ in the glass-formers reacted with the $\mathrm{NaNO}_{2}$ in the waste simulant to generate $\mathrm{NO}$ according to the reactions show below:

$$
\begin{gathered}
\mathrm{NaNO}_{2}+\mathrm{HNO}_{3} \rightarrow \mathrm{NaNO}_{3}+\mathrm{HNO}_{2} \\
3 \mathrm{HNO}_{2} \rightarrow \mathrm{H}^{+}+\mathrm{NO}_{3}+2 \mathrm{NO}^{-}+\mathrm{H}_{2} \mathrm{O}
\end{gathered}
$$

The amount of nitrate lost as a result of this reaction was calculated as $0.32 \mathrm{~kg}$ from the $\mathrm{NO}_{3}$ measurements taken during the transfer. After the transfer, the volume in the FHT was 1,965 L; the density of the slurry, $1.3 \mathrm{~kg} / \mathrm{L}$. 
The amount of sugar to be added to the feed as a reductant is determined by the amounts of $\mathrm{NO}_{2}$ and $\mathrm{NO}_{3}$ added to the slurry and by the Vitrification Lab DSRT on a series of samples containing various amounts of sugar. Tables D-1 and D-2 show the sources of nitrates in the feed, their contributions, and the results of the Vitrification Lab DSRT on the sugar feed. From this data, a target IFO is selected to produce glass with the desired redox characteristics.

Table D-1. Nitrate Balance

\begin{tabular}{|c|c|c|c|c|c|c|}
\hline & $\begin{array}{l}\text { Simulant } \\
\text { (kg) }\end{array}$ & (kg) & $\begin{array}{c}\text { Glass-Former } \\
\text { (kg) }\end{array}$ & (kg) & $\begin{array}{l}\text { Slurry } \\
\text { (kg) }\end{array}$ & (kg) \\
\hline & $\begin{array}{l}\text { Amount } \\
\text { Added }\end{array}$ & $\begin{array}{l}\text { Amount } \\
\mathrm{NO}_{3}\end{array}$ & $\begin{array}{l}\text { Amount } \\
\text { Added }\end{array}$ & $\begin{array}{l}\text { Amount } \\
\mathrm{NO}_{3}\end{array}$ & $\begin{array}{l}\text { Amount } \\
\text { Added }\end{array}$ & $\begin{array}{l}\text { Amount } \\
\mathrm{NO}_{3}\end{array}$ \\
\hline Nitric Acid & 0.00 & 0.00 & 680.10 & 234.26 & 680.10 & 234.26 \\
\hline Sodium Nitrate & 16.78 & 12.24 & 0.00 & 0.00 & 16.78 & 12.24 \\
\hline Sodium Nitrite* & 25.92 & 7.75 & 0.00 & 0.00 & 25.92 & 7.75 \\
\hline Zirconyl Oxynitrate & 78.28 & 31.69 & 47.40 & 19.19 & 125.68 & 50.88 \\
\hline $\begin{array}{l}\text { Total } \mathrm{NO}_{3} \\
\text { Total } \mathrm{NO}_{2}\end{array}$ & & 51.68 & & 253.45 & & $\begin{array}{c}305.13 \\
17.28\end{array}$ \\
\hline
\end{tabular}

*includes $\mathrm{NaNO}_{2}$ converted to $\mathrm{NO}_{3}$ per reactions (1) and (2) shown above

Table D-2. DSRT on 'Sugared' Feed

\begin{tabular}{|c|c|c|c|}
\hline IFO & $\begin{array}{c}\text { Sugar (g) } \\
\text { (250 g batch) }\end{array}$ & $\mathrm{NO}_{3} / \mathrm{TOC}$ & $\mathrm{Fe}^{+2} / \mathrm{Fe}^{+3}$ \\
\hline 2.80 & 13.27 & 5.38 & $<0.01$ \\
\hline 2.60 & 14.30 & 5.00 & 0.023 \\
\hline 2.40 & 15.49 & 4.62 & 0.263 \\
\hline 2.25 & 16.52 & 4.33 & 0.933 \\
\hline 2.13 & 17.42 & 4.10 & $0.799 *$ \\
\hline
\end{tabular}

*may contain metal precipitates

The IFO formula is: IFO $=\left(\mathrm{NO}_{3}(1-\mathrm{TS})\right) / \mathrm{TOC}$, where $\mathrm{NO}_{3}=$ nitrate concentration, $\mathrm{TS}=$ fraction of solids, and TOC $=$ total organic carbon. The DSRT indicated that an IFO of 2.25 would correspond to a $\mathrm{Fe}^{+2} / \mathrm{Fe}^{+3}$ ratio of 0.2 in the SVS-III melter using the SVS-I relationship.

The sugar addition for Run 1-04, based on the IFO formula, was calculated to be $167.5 \mathrm{~kg}(\mathrm{IFO}=2.25)$. The sugar was added to the FHT. This IFO corresponds to an IFO of 2.42 after correcting for the nitrate contribution from zirconyl nitrate. Post-sugar slurry volume, as measured by the level probe in the FHT, was $2,012 \mathrm{~L}$; density of the final slurry, $1.33 \mathrm{~kg} / \mathrm{L}$; and the oxide loading was $358 \mathrm{~g} / \mathrm{L}$. 
The waste simulant, glass-formers, and final slurry were analyzed by ICP in the A\&PC Lab. In Table D-3, the target oxide compositions for the waste simulant, glass-formers, and final slurry are compared with the analyzed oxide compositions. In the waste simulant analysis: $\mathrm{Al}_{2} \mathrm{O}_{3}$ was $9 \%$ above target, $\mathrm{B}_{2} \mathrm{O}_{3}$ was $18 \%$ high, and $\mathrm{SiO}_{2}$ was $16 \%$ high. In the glass-formers: $\mathrm{Al}_{2} \mathrm{O}_{3}$ was $13 \%$ low, $\mathrm{B}_{2} \mathrm{O}_{3}$ was $11 \%$ low, and $\mathrm{MgO}$ was $16 \%$ low. The amount of the $\mathrm{Fe}_{2} \mathrm{O}_{3}$ analyzed in the final slurry was $16 \%$ over target and $\mathrm{MgO}$ was $11 \%$ low; these are the only significant deviations from the target compositions in the final feed composition.

Table D-3. Oxide Composition and Comparison

\begin{tabular}{|c|c|c|c|c|c|c|c|c|c|c|c|c|}
\hline Oxides & $\begin{array}{l}\text { Target } \\
\text { Glass } \\
\text { (kg) }\end{array}$ & $\begin{array}{l}\text { Analyzed } \\
\text { Slurry } \\
\text { (kg) }\end{array}$ & $\begin{array}{l}\text { Diff. } \\
\text { (kg) }\end{array}$ & \% Diff. & $\begin{array}{c}\text { Target } \\
\text { Simulant } \\
\text { (kg) }\end{array}$ & $\begin{array}{l}\text { Analyzed } \\
\text { Simulant } \\
\quad(\mathrm{kg})\end{array}$ & $\begin{array}{l}\text { Diff. } \\
\text { (kg) }\end{array}$ & $\%$ Diff. & $\begin{array}{l}\text { Target } \\
\text { Glass- } \\
\text { Former } \\
\text { (kg) }\end{array}$ & $\begin{array}{l}\text { Analyzed } \\
\text { Glass- } \\
\text { Former } \\
\text { (kg) }\end{array}$ & Diff. $\%$ & $\%$ Diff. \\
\hline $\mathrm{Al}_{2} \mathrm{O}_{3}$ & 43.20 & 39.75 & 3.45 & 7.98 & 22.39 & 24.43 & -2.03 & -9.08 & 20.81 & 18.11 & 2.70 & 12.98 \\
\hline $\mathrm{B}_{2} \mathrm{O}_{3}$ & 92.81 & 91.77 & 1.04 & 1.12 & 0.43 & 0.51 & -0.08 & -18.56 & 92.38 & 82.52 & 9.86 & 10.67 \\
\hline $\mathrm{CaO}$ & 3.46 & 4.05 & -0.59 & -17.15 & 3.46 & 3.92 & -0.46 & -13.36 & & 0.05 & -0.05 & \\
\hline $\mathrm{Fe}_{2} \mathrm{O}_{3}$ & 86.54 & 100.62 & -14.08 & -16.26 & 86.54 & 93.59 & -7.05 & -8.14 & 0.00 & 0.22 & -0.22 & \\
\hline $\mathrm{K}_{2} \mathrm{O}$ & 36.00 & 33.16 & 2.84 & 7.88 & 29.30 & 27.34 & 1.96 & 6.70 & 6.70 & 6.11 & 0.58 & 8.69 \\
\hline $\mathrm{Li}_{2} \mathrm{O}$ & 26.71 & 27.52 & -0.81 & -3.02 & & 0.17 & -0.17 & & 26.71 & 25.80 & 0.91 & 3.40 \\
\hline $\mathrm{MgO}$ & 6.41 & 5.71 & 0.70 & 10.88 & 1.30 & 1.22 & 0.08 & 6.13 & 5.11 & 4.30 & 0.81 & 15.88 \\
\hline $\mathrm{MnO}$ & 5.90 & 5.89 & 0.02 & 0.29 & 4.10 & 4.24 & -0.14 & -3.36 & 1.80 & 1.26 & 0.54 & 30.13 \\
\hline $\mathrm{Na}_{2} \mathrm{O}$ & 57.60 & 60.57 & -2.97 & -5.16 & 36.00 & 36.51 & -0.51 & -1.43 & 21.60 & 19.88 & 1.72 & 7.97 \\
\hline $\mathrm{P}_{2} \mathrm{O}_{5}$ & 8.64 & 9.26 & -0.62 & -7.14 & 8.64 & 8.63 & 0.01 & 0.15 & 0.00 & 0.51 & -0.51 & \\
\hline $\mathrm{SO}_{3}$ & 1.66 & 2.88 & -1.23 & -74.11 & 1.66 & 2.31 & -0.66 & -39.69 & 0.00 & 0.46 & -0.46 & \\
\hline $\mathrm{SiO}_{2}$ & 310.68 & 313.89 & -3.21 & -1.03 & 82.94 & 95.96 & -13.01 & -15.69 & 227.16 & 209.61 & 17.55 & 57.72 \\
\hline $\mathrm{TiO}_{2}$ & 5.76 & 5.43 & 0.33 & 5.70 & 2.88 & 3.07 & -0.19 & -6.69 & 2.88 & 2.46 & 0.42 & 14.47 \\
\hline $\mathrm{ZrO}_{2}$ & 24.70 & 26.07 & -1.37 & -5.56 & 15.34 & 15.26 & 0.08 & 0.50 & 9.29 & 9.12 & 0.16 & 1.78 \\
\hline Others & 8.79 & 7.36 & & & 9.08 & 5.24 & & & 0.00 & 0.52 & & \\
\hline Total & 718.85 & 734.09 & & & 304.20 & 322.43 & & & 414.43 & 381.19 & & \\
\hline \multicolumn{3}{|c|}{ Target Volume - Final Slurry } & \multicolumn{2}{|c|}{$1,800.00 \mathrm{~L}$} & & \multicolumn{3}{|c|}{ Volume of Glass-Formers } & \multicolumn{2}{|c|}{$919.80 \mathrm{~L}$} & & \\
\hline \multicolumn{3}{|c|}{ Target Oxide Loading } & \multicolumn{2}{|c|}{$0.40 \mathrm{~kg} / \mathrm{kg}$} & & \multicolumn{3}{|c|}{ Volume of Pre-sugar Slurry } & \multicolumn{2}{|c|}{$1,964.80 \mathrm{~L}$} & & \\
\hline \multicolumn{3}{|c|}{ Target Amount of Glass } & \multicolumn{2}{|c|}{$720.00 \mathrm{~kg}$} & & \multicolumn{3}{|c|}{ Volume of Final Slurry } & \multicolumn{2}{|c|}{$2,012.00 \mathrm{~L}$} & & \\
\hline \multicolumn{3}{|c|}{ Volume of Simulant } & \multirow{2}{*}{\multicolumn{2}{|c|}{$988.00 \mathrm{~L}$}} & & \multicolumn{3}{|c|}{ Oxide Loading } & \multicolumn{2}{|c|}{$373.62 \mathrm{~g} / \mathrm{L}$} & & \\
\hline & & & & & & \multicolumn{3}{|c|}{ Final Density } & \multicolumn{2}{|c|}{$1.34 \mathrm{~kg} / \mathrm{L}$} & & \\
\hline
\end{tabular}


The properties of the slurries prepared during SVS-III Run 1-04 are summarized in Table D-4. The analyzed amount of nitrate $(273 \mathrm{~kg})$ is slightly lower than the targeted amount $(305 \mathrm{~kg})$. The possibility was explored that the nitrates contributed by zirconyl oxynitrate in both the waste simulant and glass-formers were not being analyzed by the A\&PC Lab techniques. Calculations made from the target $\mathrm{NO}_{3}$ in the final slurry, with contributions by zirconyl oxynitrate, was found to be $24.8 \mathrm{~kg}$. Adding this value to the analyzed $\mathrm{NO}_{3}$ brings the total to $297.8 \mathrm{~kg}$, which is reasonably close to the target of $305 \mathrm{~kg}$ total nitrates. The IFO calculated from the analyzed nitrates, plus nitrates from the zirconyl oxynitrate for Run 1-04, is 2.2, compared to an IFO of 2.25 based on the chemical additions. From the DSRT calculations, this IFO predicts a $\mathrm{Fe}^{+2} / \mathrm{Fe}^{+3}$ ratio of 0.9.

Table D-4. Properties of the Slurries Prepared

\begin{tabular}{|c|c|c|c|c|c|c|c|c|}
\hline Slurries & pH & $\begin{array}{l}\text { Sp. Gravity } \\
(\mathrm{kg} / \mathrm{L})\end{array}$ & $\begin{array}{l}\text { Volume } \\
\text { (L) }\end{array}$ & $\begin{array}{l}\mathrm{NO}_{3} \\
(\mathrm{~kg})\end{array}$ & $\begin{array}{l}\mathrm{NO}_{2} \\
(\mathrm{~kg})\end{array}$ & $\begin{array}{l}\text { TOC } \\
(\mathrm{kg})\end{array}$ & $\% \mathrm{TS}$ & $\begin{array}{l}\text { Oxide } \\
(\mathrm{kg} / \mathrm{kg})\end{array}$ \\
\hline $\begin{array}{l}\text { Pre-Boil } \\
\text { Simulant }\end{array}$ & 13.1 & $\begin{array}{l}1.15(\mathrm{~V}) \\
1.15(\mathrm{~L})\end{array}$ & $1,418(\mathrm{~L})$ & & & & & \\
\hline $\begin{array}{l}\text { Post-Boil } \\
\text { Simulant }\end{array}$ & 12.5 & $1.25(\mathrm{~V})$ & $988(\mathrm{~L})$ & 33.0 & $\begin{array}{l}17.9 \\
(17.3)\end{array}$ & & 34.4 (A) & $\begin{array}{l}0.27(\mathrm{~V}) \\
{[326 \mathrm{~g} / \mathrm{L})}\end{array}$ \\
\hline Glass-Former & $<1$ & $\begin{array}{l}1.41(\mathrm{~V}) \\
1.42(\mathrm{~L}) \\
1.38(\mathrm{~A})\end{array}$ & $920(\mathrm{~L})$ & $\begin{array}{l}242.4 \\
237.2(\mathrm{~A})\end{array}$ & & & $51.3(\mathrm{~A})$ & \\
\hline Pre-Sugar & 3.7 & $\begin{array}{l}1.30(\mathrm{~V}) \\
1.28(\mathrm{~L})\end{array}$ & $1,965(\mathrm{~L})$ & & & & & $\begin{array}{l}0.29 \text { (calc.) } \\
{[374 \mathrm{~g} / \mathrm{L}]}\end{array}$ \\
\hline Post-Sugar & 4.1 & $\begin{array}{l}1.31(\mathrm{~V}) \\
1.33(\mathrm{~L}) \\
1.34(\mathrm{~A})\end{array}$ & $\begin{array}{l}1,983(\mathrm{~L}) \\
2,012(\mathrm{~L})\end{array}$ & $\begin{array}{l}273.0 \\
(305)\end{array}$ & & 71.2 & $48.0(\mathrm{~A})$ & $0.27(\mathrm{~V})$ \\
\hline $\begin{array}{l}\text { Post-Nitric } \\
\text { Shim }\end{array}$ & 2.3 & $\begin{array}{l}1.30(\mathrm{~V}) \\
1.32(\mathrm{~A})\end{array}$ & $1,630(\mathrm{~L})$ & 225.3 & & 54.2 & 44.4 (A) & \\
\hline
\end{tabular}

$(\mathrm{A})=$ A\&PC Lab, (V) = Vitrification Lab, (L) = Level Probe, ( ) = Target Amounts

\subsection{Melter Operations (Run 1-04)}

SVS-III Run 1-04 was suspended after 30 hours of operation due to a high reduction level of the glass in the melter. The plenum temperature, feed rate, cold cap coverage, melter power, internal glass pool temperature, and $\mathrm{Fe}^{+2} / \mathrm{Fe}^{+3}$ ratio were monitored throughout the run to establish and maintain steady state operation.

The feed rate, cold cap coverage, and plenum temperature are interdependent. At the beginning of the run, the feed rate is high to establish a cold cap over the glass melt. Once the cold cap is established, the feed rate is reduced into the target range of 15 to $20 \mathrm{~L} / \mathrm{hr}$. The extent of the cold cap determines the plenum temperature with $\sim 85 \%$ cold cap coverage maintaining a plenum temperature in the target range of $500^{\circ}$ to $550^{\circ} \mathrm{C}$. During Run 1-04, the feed rate was initiated at $\sim 42 \mathrm{~L} / \mathrm{hr}$ and decreased to the target range within the first four hours of the run. The plenum temperature decreased from $950^{\circ}$ to $600^{\circ} \mathrm{C}$ during the first five hours of the run, stabilizing around $550^{\circ} \mathrm{C}$ for the next 10 hours, then dropping below $500^{\circ} \mathrm{C}$ for the remainder of the run. Cold cap coverage was greater than $90 \%$ after the first four hours and throughout the remainder of the run, accounting for the lower plenum temperatures. 
Between 15 and 20 hours into Run 1-04, the monitored parameters all showed changes. The plenum temperature, shown in Figure D-1, decreased from $550^{\circ}$ to below $500^{\circ} \mathrm{C}$, the internal glass pool temperature, shown in Figure D-2, fell below $1,100^{\circ} \mathrm{C}$, and the melter power, from Figure D-3, varied widely. The cold cap coverage was close to $100 \%$ and the feed rate, shown in Figure D-4, was slowed in an attempt to decrease the size of the cold cap and raise the plenum temperature.

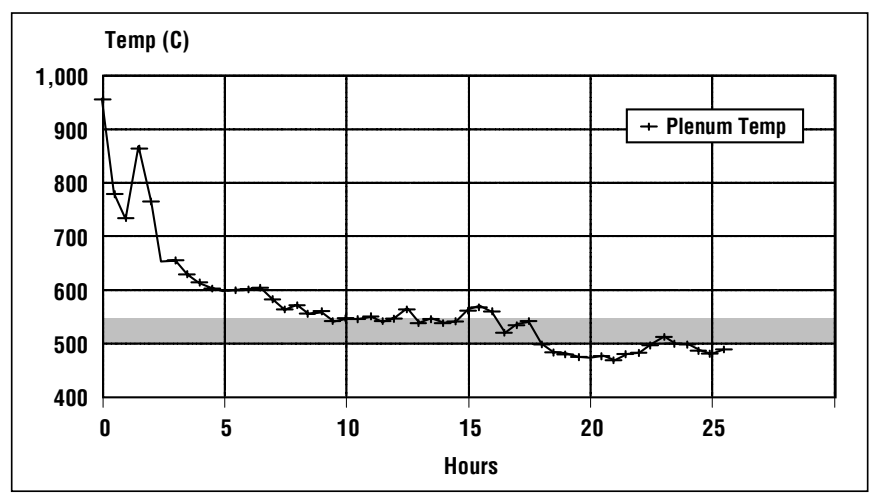

Figure D-1. Plenum Temperaturer vs. Time

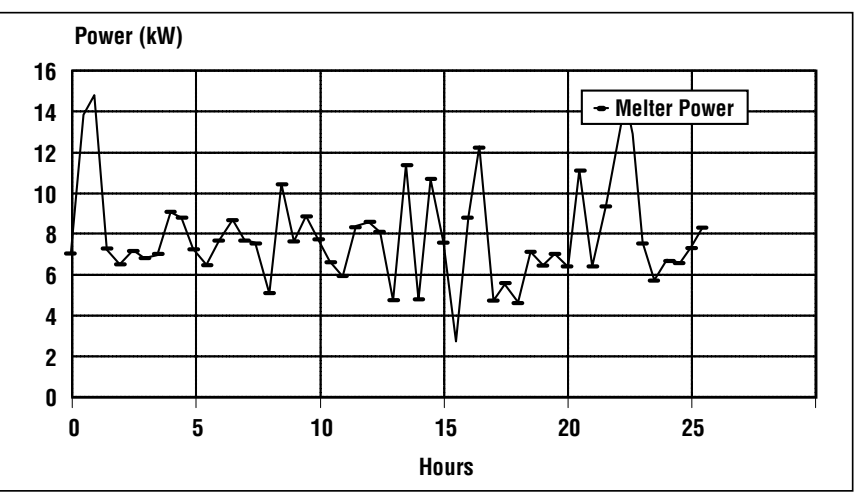

Figure D-3. Melter Power vs. Time

Figure D-5 shows the $\mathrm{Fe}^{+2} / \mathrm{Fe}^{+3}$ ratio of the glass produced in the melter as a function of melter operation time. The target ratio of 0.2 was reached after about seven hours of operation and continued to rise steadily to a maximum of 0.97 at the time the run was suspended. Between 15 and 20 hours into the run, the ratio increased from $\sim 0.5$ to 0.8 , then decreased to $\sim 0.6$, paralleling the abrupt changes in the plenum temperature, glass pool temperature, and melter power observed during this same period.

\subsection{Feed Recipe for Part II (Run 1-04')}

SVS-III Run 1-04' was started after the suspension of Run 1-04. For Run 1-04', the remaining 1,629 L of the Run 1-04 feed was shimmed with nitric acid to increase the oxidation level of the glass melt. The new IFO was 2.35 , closer in value to the range for Run 1-03.

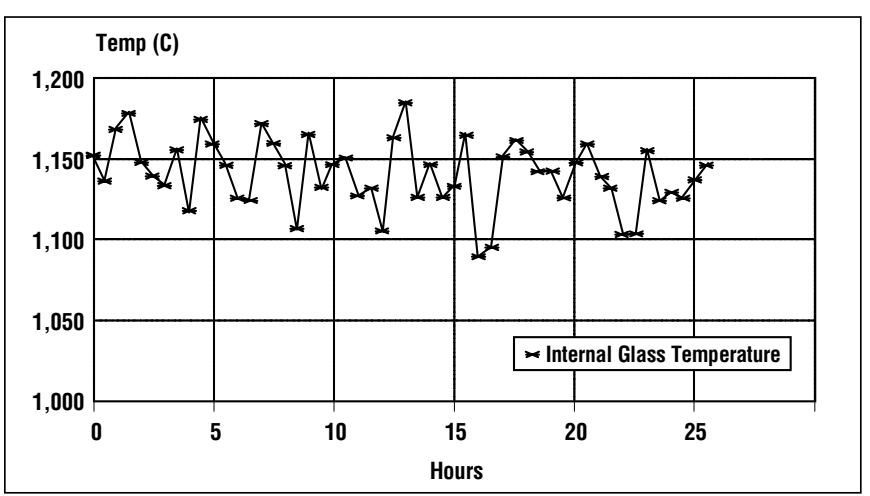

Figure D-2. Internal Glass Pool Temperature vs. Time

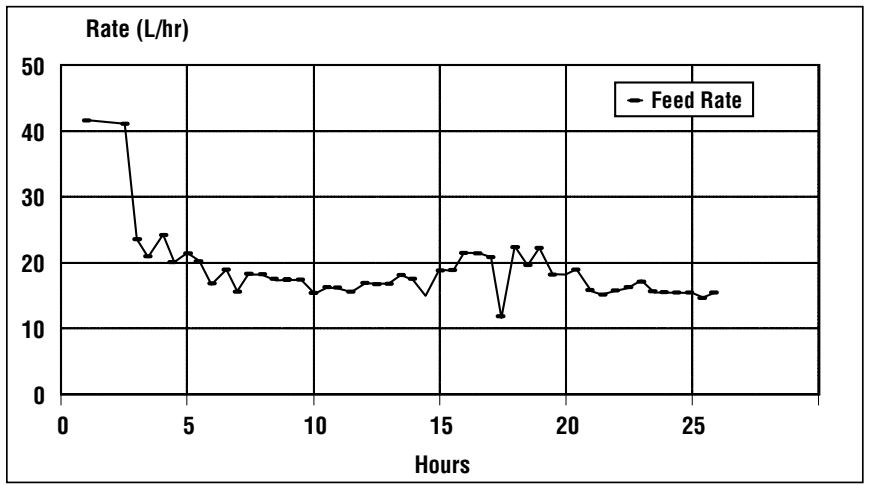

Figure D-4. Feed Rate vs. Time

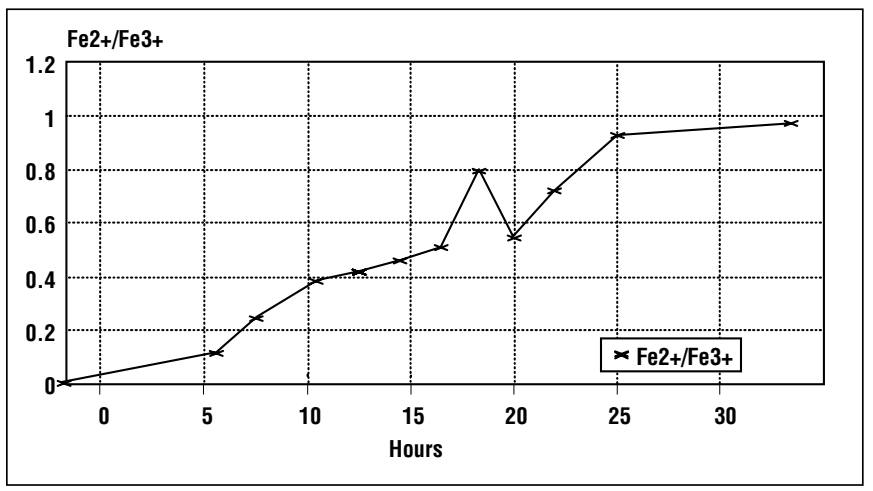

Figure D-5. Redox Ratio vs. Time 
The remaining feed from Run 1-04 was analyzed for nitrate concentration $\left(\mathrm{NO}_{3}\right)$, total organic carbon (TOC), and total solids fraction (TS). The IFO calculated from this data was 2.12. In order to bring the redox numbers down, the target IFO was increased to 2.35 (TS and TOC were estimated from post-sugar slurry analysis) and a nitric acid shim was calculated. A weight of $64.8 \mathrm{~kg}$ of $35 \%$ nitric acid was added to the slurry in the FHT. Analysis of the post-nitric shim slurry showed $\mathrm{pH}=2.3$, specific gravity $=1.30 \mathrm{~kg} / \mathrm{L}$, FHT volume $=1,630 \mathrm{~L}$, total $\mathrm{NO}_{3}=225 \mathrm{~kg}, \mathrm{TOC}=54.2 \mathrm{~kg}$, TS $=0.44$, and IFO $=2.53$. This IFO included $20.1 \mathrm{~kg}$ $\mathrm{NO}_{3}$ from zirconyl nitrates. The IFO calculated from an addition basis was 2.42 .

\subsection{Melter Operation (Run1-04')}

The melter was continuously operated for 98 hours. During the run, several key parameters were controlled and monitored to attain steady state operating conditions in the melter. The parameters that were of interest included feed rate, redox, melter plenum temperature, internal glass pool temperature, melter power, and cold cap characteristics.

The entire run could be divided into three separate regions. The first region, 0 hours to $\sim 30$ hours, represents the time required to attain steady state conditions in the melter. The second region, 30 hours to approximately 72 hours, represents the first steady state. This region is characterized by the attainment of steady plenum temperature, cold cap coverage, and feed rate. The third and final region, 72 hours until the end of the run, represents a second steady state with a slightly higher plenum temperature and corresponding lower feed rate.

The most important quantitative parameter that dictates the attainment of steady state is the plenum temperature. The feed rate is controlled to attain plenum temperature within the target range, defined as between $500^{\circ}$ and $550^{\circ} \mathrm{C}$ for Run 1-04. Figure D- 6 shows the plenum temperature as a function of the run time. At the start of the run, the plenum temperature was approximately $940^{\circ} \mathrm{C}$, with a high feed rate of $25 \mathrm{~L} / \mathrm{hr}$ used to attain a stable cold cap in the melter and reduce plenum temperature to $525^{\circ} \mathrm{C}$. The plenum temperature was stabilized around $525^{\circ} \mathrm{C}$ within 30 hours of operation. During the first steady state, 30 to 72 hours, the plenum temperature was maintained between $520^{\circ}$ and $580^{\circ} \mathrm{C}$, with an average of $\sim 525^{\circ} \mathrm{C}$. During the last part of the run, the average plenum temperature was $\sim 550^{\circ} \mathrm{C}$.

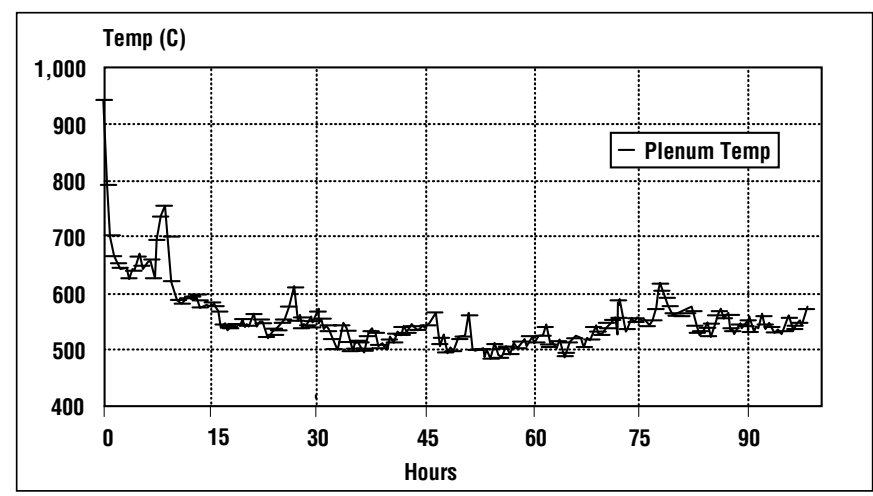

Figure D-6. Plenum Temperature vs. Time

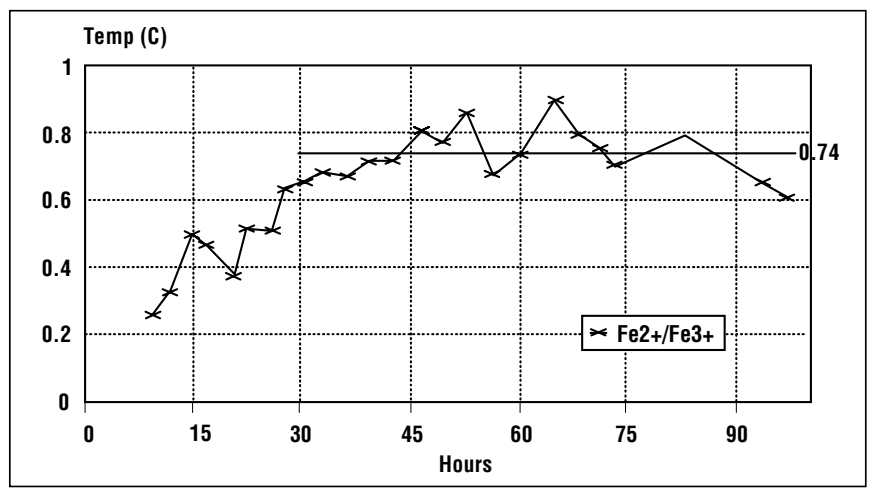

Figure D-7. Redox Ratio vs. Time

Figure D-7 shows the $\mathrm{Fe}^{+2} / \mathrm{Fe}^{+3}$ ratio as a function of run hours. The $\mathrm{Fe}^{+2} / \mathrm{Fe}^{+3}$ ratio varied between 0.65 and 0.90 during the first steady state period (30 to 72 hours). The average $\mathrm{Fe}^{+2} / \mathrm{Fe}^{+3}$ ratio during this period was 0.74 . The variation in the $\mathrm{Fe}^{+} / \mathrm{Fe}^{+3}$ data is attributed to a combination of temperature, composition, cold cap fluctuations within the melter, and measurement errors associated with the analysis of the $\mathrm{Fe}^{+2} / \mathrm{Fe}^{+3}$ ratio. The steady state region with the higher plenum temperature showed no significant change in the $\mathrm{Fe}^{+2} /$ $\mathrm{Fe}^{+3}$ ratio. 
The last two $\mathrm{Fe}^{+2} / \mathrm{Fe}^{+3}$ data points were slightly lower than the steady state average. Perhaps if the run had continued, a more precise conclusion could be made regarding the effect of the plenum temperature on the $\mathrm{Fe}^{+2} / \mathrm{Fe}^{+3}$ ratio. Further tests will be made to determine whether plenum temperature has a significant impact or if it is simply an artifact of redox analysis.

The data for Runs 1-04/1-04' indicate that the redox conditions were on the extremely reducing end for the initial part of the runs, which were suspended before the $\mathrm{Fe}^{+2} / \mathrm{Fe}^{+3}$ ratio exceeded 1.0. The slurry was subsequently shimmed with nitric acid and the runs were continued. Redox data points for test runs 1-04 and 1-04' are shown in Figure 18 of Section 5.3.1. Based on the initial redox response, it was estimated that, had the run continued, the glass would have attained a $\mathrm{Fe}^{+2} / \mathrm{Fe}^{+3}$ ratio of $\sim 3.0$.

After the nitric acid shim, a steady state $\mathrm{Fe}^{+2} / \mathrm{Fe}^{+3}$ ratio of 0.74 was attained providing an upper-end data point for the IFO index and operating range of the SVS-III melter. The redox response also indicates that for this run, a given IFO results in more reduction than in SVS-I or the SFCM. Based on recent Vitrification Lab studies, the steep slope for the redox vs. IFO in the SVS-III melter is attributed to the presence of sodium nitrite and noble metals in the feed.

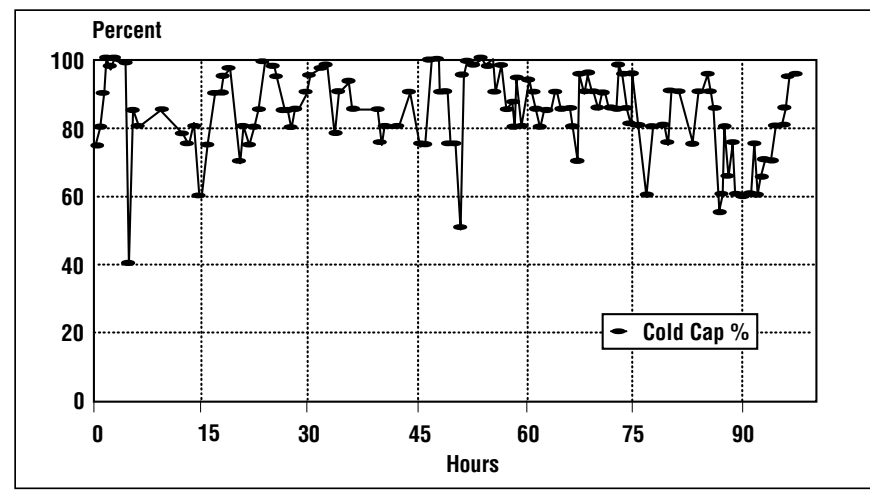

Figure D-8. Percent Cold Cap Coverage vs. Time

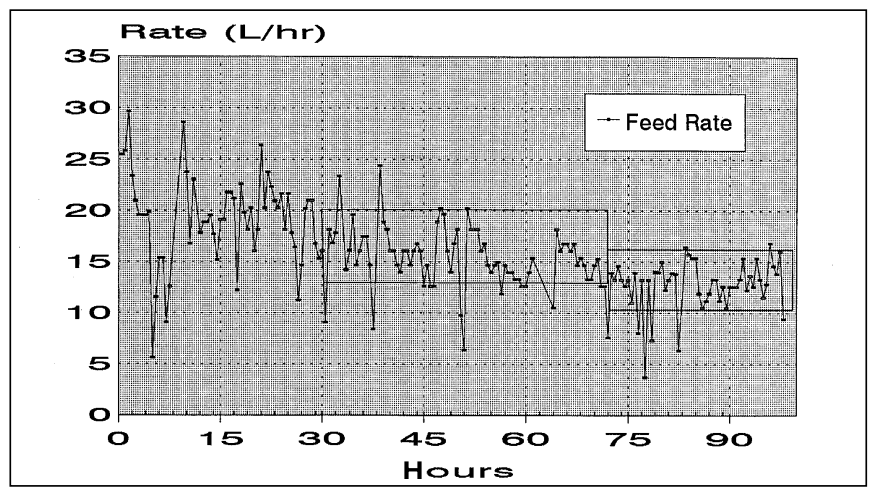

Figure D-9. Feed Rate vs. Time

Figure D-8 shows the qualitative estimate of the operators' visual observations of the cold cap coverage in the melter. In the first steady state region, 30 to 72 hours, the cold cap coverage was maintained between 75 and $100 \%$; within the range expected during the run. It should be noted that the description of the cold cap coverage could vary throughout the run depending on the interpretation of the individual operator at the time the sketch was made, or discrepancies among the different operators throughout the run.

Feed rate, plotted as a function of time, is shown in Figure D-9. The feed rate data was collected every 30 minutes and was plotted as the actual amount of feed delivered to the melter in each 30-minute interval in order to exclude interruptions due to plugging of the feed nozzle or the off-gas lines. During the first steady state period, the feed rate was maintained between 13 and $20 \mathrm{~L} / \mathrm{hr}$. This range provided a stable cold cap with an average coverage of $\sim 85 \%$ and a plenum temperature range between $490^{\circ}$ and $500^{\circ} \mathrm{C}$. During the last 26 hours of Run 1-04', which represents the second steady state region, the feed rate was maintained between 10 and $15 \mathrm{~L} / \mathrm{hr}$. At the same time there was a steady increase in the average plenum temperature as less feed was delivered to the top of the glass pool.

Figures D-10 and D-11 show the electrode power and the internal glass temperature, respectively. The melter electrode power was maintained between 5 and $11 \mathrm{~kW}$. The average electrode power was $\sim 8 \mathrm{~kW}$. During the course of Run 1-04', the internal glass temperature ranged between $1,125^{\circ}$ and $1,175^{\circ} \mathrm{C}$, with an average temperature of $1,145^{\circ} \mathrm{C}$. Both electrode power and internal glass temperature indicate that the melter operating conditions did not change during this run. 


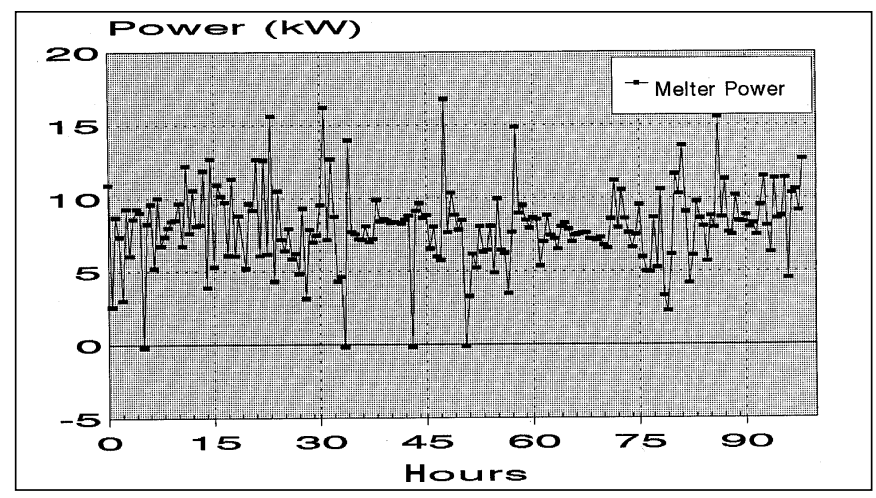

Figure D-10. Melter Power vs. Time

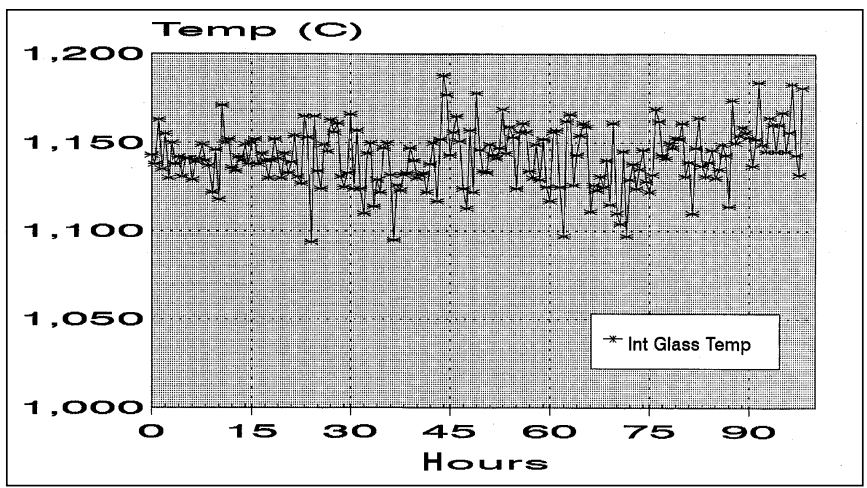

Figure D-11. Internal Glass Pool Temperature vs. Time

\subsection{Summary (Both Runs)}

In SVS-III Runs 1-04 and 1-04', a higher redox state than that of the three previous series 1 test runs was targeted. The feed slurry recipe, based on the Reference 6 target glass composition, was calculated to produce $720 \mathrm{~kg}$ of glass with a Fe $\mathrm{Fe}^{+2} / \mathrm{Fe}^{+3}$ ratio of 0.2 . Relative to Run 1-03, the amount of nitrate added to the slurry in Run 1-04 was reduced and the amount of sugar added was increased to promote reduction of the glass melt. Heel simulation was not included in the feed preparation cycle.

Waste simulant chemical additions to the SMT for Run 1-04 were started and completed on March 5, 1995. The waste simulant was then transferred from the SMT to the FHT, and the glass-former chemicals were then added to the SMT. After boiling down the waste simulant in the FHT, the glass-formers were then transferred to the FHT to be mixed with the waste simulant. A weight of $167.5 \mathrm{~kg}$ of sugar was added to the slurry in the FHT and then the feed melter was started on March 13, 1995.

The target $\mathrm{Fe}^{+2} / \mathrm{Fe}^{+3}$ ratio of 0.2 was reached after about seven hours of operation and continued to climb; reaching 0.93 after about 30 hours. Due to the high redox state of the glass and the risk of damage to the melter from continued operation with such highly reduced glass, Run 1-04 was suspended on March 14, 1995 while a strategy for corrective measures was developed.

Analyzed nitrate values from the A\&PC Lab have been consistently low compared to values calculated from the amounts of chemicals added. The possibility that the nitrates from zirconyl oxynitrate were not being detected in the analysis was explored and it was confirmed that the lab tests could not analyze for these nitrates. Because the sugar additions are determined based on the analyzed nitrates and the Vitrification Lab slurry melt tests, the nitrates from the zirconyl nitrate must be calculated from the actual amounts in the slurry recipes and then added to the total nitrate analyzed value to arrive at a more accurate sugar addition.

A nitric acid shim of $64.8 \mathrm{~kg}$ was added to the FHT, and feed to the melter was restarted on March 27, 1995. The $\mathrm{Fe}^{+2} / \mathrm{Fe}^{+3}$ ratio stabilized around 0.6 to 0.8 after about 25 hours of melter operation.

SVS-III Runs 1-04 and 1-04' provide a data point high on the reducing end of the Redox Forecasting Model. During the post-nitric acid shim part of the run, the $\mathrm{Fe}^{+2} / \mathrm{Fe}^{+3}$ ratio remained fairly constant in the 0.6 to 0.8 range with an average ratio of 0.74 . Throughout this test run the melter parameters were difficult to control, however steady state conditions were achieved in Run 1-04' after 30 hours of operation. The composition of the glass melt did not reach a steady state as concentrations of the major oxide constituents varied throughout the run. The composition began to stabilize during the last 30 hours. 


\section{APPENDIX E:}

\subsection{SVS-III RUN 1-05}

\subsection{Objectives}

SVS-III Run 1-05 concentrated on the following objectives:

- Targeting a redox ratio of 0.4 for the Redox Forecasting Model

- Installing the Hydragard ${ }^{\circledR}$ sampling system to obtain samples from the feed hold tank (FHT)

- Preparing enough feed to produce $720 \mathrm{~kg}$ of glass.

\subsection{Feed Preparation}

The feed preparation for the SVS-III operation is comprised of several steps necessary for the production of acceptable slurry feed for vitrification in the SVS-III mini-melter. The main steps for the production of acceptable slurry feed are listed below:

- Addition of chemicals to the slurry mix tank (SMT) to make up the simulant

- Transfer the waste simulant from the SMT to the FHT

- Pull process control samples of the contents of the FHT (waste simulant) before boiling

- Boil the contents of the FHT to remove excess water

- Pull process control samples of the FHT (waste simulant) after boiling the contents

- Addition of chemicals to the SMT to make up the glass-formers

- Pull process control samples of the SMT (glass-formers)

- Lower the temperature of the FHT to $<30^{\circ} \mathrm{C}$ for the addition of the contents of the SMT to the FHT

- Pull process control samples of the FHT (slurry)

- Addition of sugar to the FHT based on analysis of the slurry samples pulled for process control

- Transfer contents from the FHT to the melter feed tank (MFT) on a batch basis (continuous feeding of the melter is maintained from the MFT).

The chemicals are added in sequence to ensure that the waste simulant and glass-formers become homogeneous so that transferring the contents of the SMT to the FHT is possible. It should be noted that Run 1-05 was started with little or no heel present in the tanks. 
The boiling down of the waste simulant in the FHT resulted in approximately $131.2 \mathrm{~L}$ of the original $134.00 \mathrm{~L}$ of water added to the simulant being boiled away. The final volume of the tank was 871.3 L. Upon completion of the boil-down in the FHT, the glass-former addition in the SMT was initiated. The chemicals added to this tank were done in sequence per Table 4 of Section 4.0.

The installation of the Hydragard ${ }^{\circledR}$ sampling system (on the FHT) and testing with water was completed on schedule. The sampling system seemed to be performing as expected until the sampling system was utilized to sample the waste simulant. The system plugged and could not retrieve the required samples. It was decided that there was an approximately 6-inch dead space between the recirculation pipe and the sampling system. A decision was made to reinstall and use the old sampling system until proper modification could be made to the Hydragard ${ }^{\circledR}$ sampling system.

\subsubsection{NO Generation}

$\mathrm{NO}_{\mathrm{x}}$ generation in the FHT transpires when glass-formers from the SMT are added to the FHT after concentration. The reactions listed below occur upon transferring the glass-formers to the FHT:

$$
\begin{aligned}
& \mathrm{NaNO}_{2}+\mathrm{HNO}_{3} \rightarrow \mathrm{NaNO}_{3}+\mathrm{HNO}_{2} \\
& 3 \mathrm{HNO}_{2} \rightarrow \mathrm{H}^{+}+\mathrm{NO}_{3}{ }^{-}+2 \mathrm{NO}+\mathrm{H}_{2} \mathrm{O}
\end{aligned}
$$

An attempt was made to control the temperature of the FHT at $25^{\circ} \mathrm{C}$. It is believed that controlling the temperature of the tank may prevent the $\mathrm{NO}_{\mathrm{x}}$ spikes of $10,000 \mathrm{ppm}$ or greater from entering the off-gas system. It was noted before the transfer that the temperature of the SMT was about $42^{\circ} \mathrm{C}$. This could explain the 3-minute $\mathrm{NO}_{\mathrm{x}}$ spikes of $10,000 \mathrm{ppm}$ experienced at the inlet of the off-gas system. It was suggested that the SMT temperature should be maintained at the same temperature as the FHT to prevent these sudden spikes of $10,000 \mathrm{ppm}$ or greater on the inlet side of the off-gas system. The amount of nitrates lost due to these reactions was approximately $1.92 \mathrm{~kg}$. The final volume and density were $1,707.3 \mathrm{~L}$ and $1.35 \mathrm{~kg} /$ L, respectively.

\subsubsection{Reductant Addition}

The amount of reductant to be added to the slurry was calculated to be $152.0 \mathrm{~kg}$ of sugar. This is based on the Vitrification Lab redox tests and the IFO formula that utilizes data from the nitrate balance, mass fraction of total solids in the slurry, and the total carbon concentration. The formula listed below outlines the relationship between each of these components:

$$
\mathrm{IFO}=\mathrm{NO}_{3}(1-\mathrm{TS}) / \mathrm{TOC}
$$

where $\mathrm{NO}_{3}$ is the nitrate concentration, TS is the mass fraction of total solids in the slurry, TOC is the total organic carbon, and ( 1 - TS) is the mass fraction of water in the slurry.

The nitrate balance is based on chemical components that contribute nitrates to the slurry. The contribution of nitrates occurred during the preparation of the waste simulant and the glass-former additions. Table E-1 provides a list of these chemical components and the amounts they each contribute. 
In order to determine how much sugar to add to the slurry, the IFO formula and the Vitrification Lab redox tests are utilized. The Vitrification Lab redox tests are performed to target different IFO numbers utilizing a $250 \mathrm{~g}$ batch of slurry and adding different amounts of sugar. For Run 1-05, the Vitrification Lab indicated a significant oxidizing behavior compared to Run 1-04. Eight tests were performed in the Vitrification Lab utilizing the DSRT method. Samples were analyzed for $\mathrm{Fe}^{+2} / \mathrm{Fe}^{+3}$ and averaged. A redox test was redone utilizing sugar from the SVS-III, and the results from that DSRT demonstrated that an IFO of 2.45 corresponded to an average $\mathrm{Fe}^{+2} / \mathrm{Fe}^{+3}$ ratio of 0.46 in the melter (the target was a $\mathrm{Fe}^{+2} / \mathrm{Fe}^{+3}$ ratio of 0.4 ). The required amount of sugar that corresponded to an IFO of 2.45 was $16.39 \mathrm{~g}$ of sugar. Based on this information, the calculated nitrates and the IFO formula (the sugar amount required to achieve this ratio in the melter) was calculated to be $152.0 \mathrm{~kg}$.

Table E-1. Nitrate Balance

\begin{tabular}{|c|c|c|c|}
\hline Nitrate Sources & Simulant (kg) & Glass-Former (kg) & Slurry (kg) \\
\hline Nitric Acid (35\%) & --- & 680.10 & 680.10 \\
\hline Sodium Nitrate & 16.78 & --- & 16.78 \\
\hline Sodium Nitrite & 25.92 & --- & 25.92 \\
\hline \multirow[t]{2}{*}{ Zirconyl Nitrate } & 78.28 & 47.40 & 125.68 \\
\hline & Simulant (kg) & Glass-Former (kg) & Slurry (kg) \\
\hline Nitric Acid (35\%) & --- & 234.26 & 234.26 \\
\hline Sodium Nitrate & 12.24 & --- & 12.24 \\
\hline Sodium Nitrite* & --- & --- & $7.75^{*}$ \\
\hline Zirconyl Nitrate** & 31.69 & 19.19 & 50.88 \\
\hline Total $\mathrm{NO}_{3}$ & 43.93 & 253.45 & 305.13 \\
\hline Total $\mathrm{NO}_{2} *$ & 17.28 & --- & --- \\
\hline
\end{tabular}

$* 0.299 \mathrm{~kg}$ of $\mathrm{NO}_{3} / \mathrm{kg}$ of $\mathrm{NaNO}_{2}$ per reactions in Section 1.2.0

** contains $42.5 \%$ zirconyl nitrate and $21.1 \% \mathrm{HNO}_{3}$

The IFO number was recalculated based on the analyzed results of the slurry. The IFO number was 2.43 compared to the IFO number of 2.45 based on the addition basis. The results indicated that the IFOs are not significantly different.

The analyzed total organic carbon (TOC) number was $66 \mathrm{~kg}$, which is $3.1 \%$ higher that the calculated TOC number of $64 \mathrm{~kg}$. The analyzed nitrate number for the final slurry was $289 \mathrm{~kg}$. This number does not include the nitrate coming from the zirconyl nitrate. The A\&PC Lab cannot analyze for this component, so the calculated amount must be added to the final nitrate number. The resulting nitrate number from the addition of these two numbers was $313.77 \mathrm{~kg}$, which exceeded the calculated nitrate number of $305.13 \mathrm{~kg}$. The amount of sugar added to each $250 \mathrm{~g}$ batch and the resulting ferrous-to-ferric ratios are presented in Table E-2. 
Table E-2: DSRT on Sugar Feed

\begin{tabular}{lccc} 
IFO & Amount of Sugar Added (kg) & Nitrate-to-Carbon Ratio & $\mathbf{F e}^{+2} / \mathbf{F e}^{+3} \mathbf{R a t i o}$ (Average) \\
2.56 & 15.63 & 5.03 & $<0.01$ \\
2.51 & 15.95 & 4.93 & $<0.01$ \\
2.46 & 16.28 & 4.83 & 0.01 \\
2.46 & 16.28 & 4.83 & 0.043 \\
$2.45^{*}$ & $16.39^{*}$ & $4.80^{*}$ & $0.460^{*}$ \\
2.40 & 16.74 & 4.70 & 0.057 \\
2.35 & 17.10 & 4.60 & 0.123 \\
2.30 & 17.48 & 4.50 & 0.58 \\
\hline
\end{tabular}

*This experiment utilized sugar from the SVS-III. The rest of the experiments utilized sugar from the Vitrification Lab.

DSRT on Post-sugar Feed

\begin{tabular}{|c|c|c|c|}
\hline IFO & Amount of Sugar Added (kg) & Nitrate-to-Carbon Ratio & $\mathrm{Fe}^{+2} / \mathrm{Fe}^{+3}$ Ratio (Average) \\
\hline 2.45 & 152.0 & 4.80 & 0.41 \\
\hline
\end{tabular}

Table E-3 presents the averages of the A\&PC Lab results of the waste simulant, glass-former, and the final slurry compared to their target compositions. The waste simulant analysis shows $\mathrm{Fe}_{2} \mathrm{O}_{3}$ being $11.51 \%$ low along with $\mathrm{K}_{2} \mathrm{O} 14.98 \%$ low, $\mathrm{P}_{2} \mathrm{O}_{5}$ low at $10.58 \%$, and $\mathrm{CaO} 10.79 \%$ high. The glass-former analysis shows $\mathrm{MgO}$ being low at $70.98 \%$. The final slurry analysis shows $\mathrm{B}_{2} \mathrm{O}_{3}$ low at $13.33 \%$ and $\mathrm{K}_{2} \mathrm{O}$ low at $11.18 \%$. The two components that are off for the final slurry are due to the A\&PC Lab's technique of analysis.

Table E-4 presents the properties of the slurries during Run 1-05.

\subsection{Melter Operation}

Melter operation commenced after repair to the melter feed tank (MFT) agitator was complete. Run 1-05 ended upon emptying the MFT. The following key parameters are important for attaining steady state conditions in the melter and are monitored on a continuous basis: feed rate, plenum temperature, cold cap coverage, redox, internal glass temperature, and melter power. Melter operation is split into two modes based on monitoring and controlling the previously stated key parameters. The first mode of melter operation, start to 35 hours, is spent striving for the first steady state; the second mode of melter operation, 35 hours to the end, is spent maintaining the first steady state. These key parameters just listed are important throughout the entire melter operation and are discussed in the following sections. 
Table E-3. Oxide Composition (in kg)

\begin{tabular}{|c|c|c|c|c|c|c|c|c|c|c|c|c|}
\hline Oxides & $\begin{array}{l}\text { Target } \\
\text { Glass } \\
(\mathbf{k g})\end{array}$ & $\begin{array}{l}\text { Analyzed } \\
\text { Slurry } \\
\text { (kg) }\end{array}$ & $\begin{array}{l}\text { Diff. } \\
\text { (kg) }\end{array}$ & \% Diff. & $\begin{array}{c}\text { Target } \\
\text { Simulant } \\
(\mathbf{k g})\end{array}$ & $\begin{array}{c}\text { Analyzed } \\
\text { Simulant } \\
\quad(k g)\end{array}$ & $\begin{array}{l}\text { Diff. } \\
\text { (kg) }\end{array}$ & $\%$ Diff. & $\begin{array}{c}\text { Target } \\
\text { Glass- } \\
\text { Former } \\
(\mathbf{k g})\end{array}$ & $\begin{array}{l}\text { Analyzed } \\
\text { Glass- } \\
\text { Former } \\
\text { (kg) }\end{array}$ & $\begin{array}{l}\text { Diff. } \\
\text { (kg) }\end{array}$ & \%Diff. \\
\hline $\mathrm{Al}_{2} \mathrm{O}_{3}$ & 43.20 & 40.27 & 2.93 & 6.79 & 22.39 & 20.20 & 2.19 & 9.78 & 20.81 & 20.50 & 0.31 & 1.49 \\
\hline $\mathrm{B}_{2} \mathrm{O}_{3}$ & 92.81 & 80.44 & 12.37 & 13.33 & 0.43 & 0.60 & -0.17 & -38.66 & 92.38 & 86.83 & 5.55 & 6.00 \\
\hline $\mathrm{CaO}$ & 3.46 & 3.81 & -0.36 & -10.34 & 3.46 & 3.83 & -0.37 & -10.79 & & & & \\
\hline $\mathrm{Fe}_{2} \mathrm{O}_{3}$ & 86.54 & 86.36 & 0.18 & 0.21 & 86.54 & 75.04 & 11.51 & 13.30 & 0.00 & & & \\
\hline $\mathrm{K}_{2} \mathrm{O}$ & 36.00 & 31.97 & 4.03 & 11.18 & 29.30 & 24.91 & 4.39 & 14.98 & 6.70 & 6.19 & 0.51 & 7.58 \\
\hline $\mathrm{Li}_{2} \mathrm{O}$ & 26.71 & 27.27 & -0.56 & -2.11 & & 0.06 & -0.06 & & 26.71 & 26.05 & 0.67 & 2.49 \\
\hline $\mathrm{MgO}$ & 6.41 & 5.87 & 0.54 & 8.47 & 1.30 & 1.10 & 0.19 & 14.85 & 5.11 & 1.48 & 3.63 & 70.98 \\
\hline $\mathrm{MnO}$ & 5.90 & 5.90 & 0.01 & 0.12 & 4.10 & 3.86 & 0.24 & 5.93 & 1.80 & 1.68 & 0.12 & 6.66 \\
\hline $\mathrm{Na}_{2} \mathrm{O}$ & 57.60 & 58.85 & -1.25 & -2.17 & 36.00 & 32.59 & 3.41 & 9.48 & 21.60 & 20.91 & 0.69 & 3.21 \\
\hline $\mathrm{P}_{2} \mathrm{O}_{5}$ & 8.64 & 8.45 & 0.19 & 2.18 & 8.64 & 7.73 & 0.91 & 10.58 & 0.00 & & & \\
\hline $\mathrm{SO}_{3}$ & 1.66 & 2.25 & -0.60 & -36.05 & 1.66 & 2.09 & -0.44 & -26.43 & 0.00 & & & \\
\hline $\mathrm{SiO}_{2}$ & 310.68 & 327.73 & -17.05 & -5.49 & 82.94 & 77.30 & 5.64 & 6.80 & 227.16 & 228.99 & -1.83 & -0.81 \\
\hline $\mathrm{TiO}_{2}$ & 5.76 & 5.06 & 0.70 & 12.12 & 2.88 & 2.48 & 0.40 & 13.80 & 2.88 & 2.57 & 0.31 & 10.88 \\
\hline $\mathrm{ZrO}_{2}$ & 24.70 & 25.06 & -0.36 & -1.46 & 15.34 & 14.04 & 1.30 & 8.46 & 9.29 & 8.98 & 0.31 & 3.34 \\
\hline Others & 8.89 & 5.79 & & & 9.22 & 5.12 & & & 0.00 & 0.00 & & \\
\hline Total & 718.85 & 715.09 & 3.76 & & 304.20 & 270.95 & 33.25 & & 414.43 & 404.17 & & \\
\hline \multicolumn{3}{|c|}{ Target Volume - Final Slurry } & \multicolumn{2}{|c|}{$1,800.00 \mathrm{~L}$} & & \multicolumn{3}{|c|}{ Target Oxide Loading } & \multicolumn{2}{|c|}{$0.40 \mathrm{~kg} / \mathrm{kg}$} & & \\
\hline \multicolumn{3}{|c|}{ Target Amount of Glass } & \multicolumn{2}{|c|}{$720.00 \mathrm{~kg}$} & & \multicolumn{3}{|c|}{ Volume of Simulant } & \multicolumn{2}{|l|}{$871.30 \mathrm{~L}$} & & \\
\hline \multicolumn{3}{|c|}{ Volume of Glass-formers } & \multicolumn{2}{|c|}{$846.30 \mathrm{~L}$} & & \multicolumn{3}{|c|}{ Volume of Pre-sugar Slurry } & \multicolumn{2}{|c|}{$1,707.30 \mathrm{~L}$} & & \\
\hline \multicolumn{3}{|c|}{ Volume of Final Slurry } & \multicolumn{2}{|c|}{$1,803.20 \mathrm{~L}$} & & \multicolumn{3}{|c|}{ Oxide Loading } & \multicolumn{2}{|c|}{$396.57 \mathrm{~g} / \mathrm{L}$} & & \\
\hline Final D & ensity & & 1.38 & $\mathrm{~kg} / \mathrm{L}$ & & & & & & & & \\
\hline
\end{tabular}

\subsubsection{Feed Rate}

The feed rate to the melter for Run 1-05 was basically consistent between the range of 10 to $28 \mathrm{~L} / \mathrm{hr}$ with a few interruptions. The feed rate started out at approximately $26 \mathrm{~L} / \mathrm{hr}$ to establish the cold cap in the melter. Upon establishing the cold cap for the melter, the feed rate was backed down to 17 to $18 \mathrm{~L} / \mathrm{hr}$ to maintain cold cap coverage of $90 \%$. The feed rate was interrupted to the melter several times and the following list is a summary of these interruptions: flushing the feed line, replacement of the feed pump hose, the scrubber pump tripping the system, the host blower (fluid bed reactor) going off, melter feed line pluggage, reaming the feed nozzle, the melter temperature rising to burnout due to temperature excursion during an airlift, a decrease of cold cap size in the melter, FHT transfer to the MFT, replacing the MFT dip tube, and lowering the dip tube into the MFT. The feed rate to the melter for 100 hours of operation was maintained at $20 \pm 5 \mathrm{~L} /$ hr. The feed rate to the melter is plotted versus time and is presented in Figure E-1. 
Table E-4. Slurry Properties

\begin{tabular}{|c|c|c|c|c|c|c|c|}
\hline Slurries & pH & $\begin{array}{l}\text { Specific } \\
\text { Gravity } \\
(\mathrm{kg} / \mathrm{L})\end{array}$ & $\mathrm{NO}_{3}(\mathrm{~kg})$ & $\mathrm{NO}_{2}(\mathrm{~kg})$ & TOC (kg) & $\%$ TS & Oxide (g/L) \\
\hline Pre-boil Simulant & 12.9 & 1.23 & $\begin{array}{l}27.43 \\
+15.43 * \\
42.86(\mathrm{~A}) \\
43.93(\mathrm{~T})\end{array}$ & $\begin{array}{l}17.023(\mathrm{~A}) \\
17.28(\mathrm{~T})\end{array}$ & - & 30.04 & - \\
\hline Post-boil Simulant & 12.8 & 1.27 & $\begin{array}{l}27.94 \\
43.37(\mathrm{~A}) \\
43.93(\mathrm{~T})^{* *}\end{array}$ & $\begin{array}{l}17.46(\mathrm{~A}) \\
17.28(\mathrm{~T})\end{array}$ & - & 33.33 & $\begin{array}{l}311.00(\mathrm{~A}) \\
349.91(\mathrm{~T})\end{array}$ \\
\hline Glass-former & $<1$ & 1.45 & $\begin{array}{l}262.24 \\
+.348^{*} \\
271.59(\mathrm{~A}) \\
253.45(\mathrm{~T})\end{array}$ & - & - & 34.89 & $\begin{array}{l}477.60(\mathrm{~A}) \\
489.70(\mathrm{~T})\end{array}$ \\
\hline Pre-sugar Slurry & 3.41 & 1.35 & $\begin{array}{l}274.85 \\
+24.77^{*} \\
299.62(\mathrm{~A}) \\
305.13(\mathrm{~T})\end{array}$ & - & - & 46.41 & $\begin{array}{l}\text { 418.84(A) } \\
421.04(\mathrm{~T})\end{array}$ \\
\hline Post-sugar Slurry & 3.59 & 1.37 & $\begin{array}{l}289.00 \\
+24.77 * \\
313.77(\mathrm{~A}) \\
305.13(\mathrm{~T})\end{array}$ & - & $\begin{array}{l}66.68(\mathrm{~A}) \\
64.0(\mathrm{~T})\end{array}$ & 48.95 & 398.6(T) \\
\hline
\end{tabular}

*Is the amount of $\mathrm{NO}_{3}$ from the zirconyl nitrate not accounted for by the nitrate analysis $* * \mathrm{NO}_{2}$ has not yet reacted to form $\mathrm{NO}_{3}$

(A) Analytical results

(T) Calculated target amounts

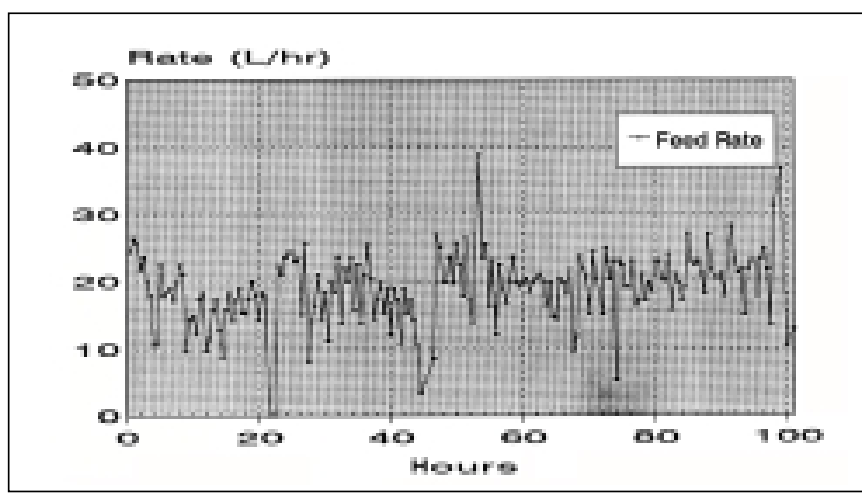

Figure E-1. Feed Rate vs. Time

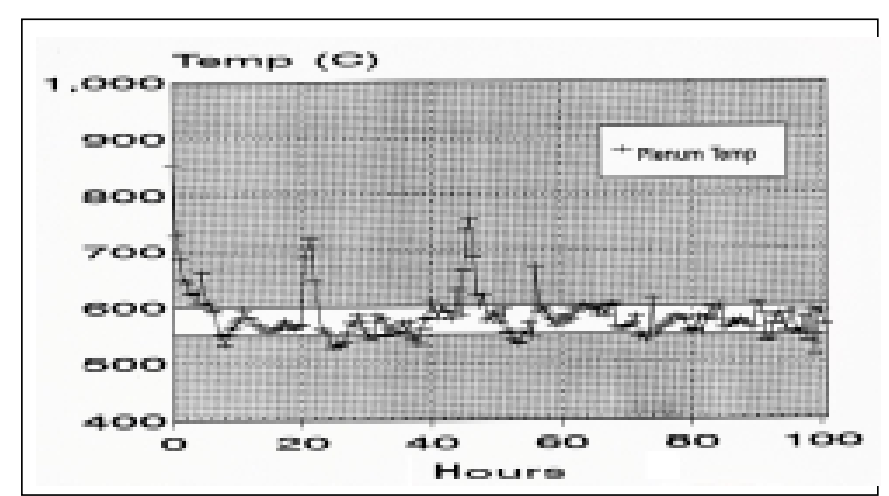

Figure E-2. Plenum Temperature vs. Time 


\subsubsection{Plenum Temperature}

The plenum temperature for the first 6 hours of melter operation dropped from approximately $850^{\circ} \mathrm{C}$ to the desired plenum temperature of $550^{\circ} \mathrm{C}$. The reason for this temperature drop was due to the formation of the cold cap in the melter. Referring to Figure E-2, it can be seen that the plenum temperature was basically consistent during the entire run. There are a few occurrences that caused the plenum temperature to be under or exceed the expected operating range. The exceedance of the plenum temperature outside the expected operating range can be explained by feed interruptions and melter power

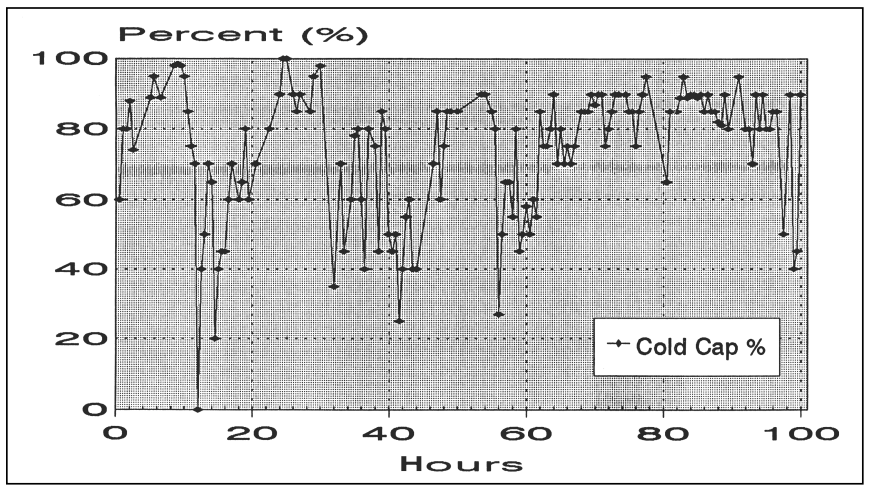

Figure E-3. Percent Cold Cap Coverage vs. Time outages that caused the cold cap to partially or totally disappear. Upon cold cap disappearance, the plenum temperature began to rise and exceed the operating range until the cold cap could be reestablished. During the run, the plenum temperature ranged between $550^{\circ}$ and $600^{\circ} \mathrm{C}$. The operation of the plenum temperature on the low side would suggest that the cold cap coverage ranged between 90 and $99 \%$.

\subsubsection{Cold Cap Coverage}

Cold cap coverage for Run 1-05 was inconsistent for the first 60 hours of melter operation and fairly consistent for the last 40 hours of operation. The inconsistencies in the cold cap coverage for the first 60 hours of operation could be explained by all the feed interruptions to the melter (listed in Section E. 3.0) and the powering down of the melter. The graph of the cold cap coverage was generated from operator drawings of the cold cap coverage during the operation of the melter. This qualitative judgement appears in Figure E-3.

\subsubsection{Redox}

The redox numbers for the $\mathrm{Fe}^{+2} / \mathrm{Fe}^{+3}$ ratio in the melter for the entire 1-05 run were within the expected range. Figure $\mathrm{E}-4$ depicts the $\mathrm{Fe}^{+2} / \mathrm{Fe}^{+3}$ ratio over time for melter operation. During the first 20 hours of melter operation, the $\mathrm{Fe}^{+2} / \mathrm{Fe}^{+3}$ ratio was slowly increasing from 0.15 towards the desired 0.4 ratio. The desired ratio of 0.4 was attained after 30 hours of melter operation. This trend continued for the rest of Run 1-05, with an occasional increase in the $\mathrm{Fe}^{+2} / \mathrm{Fe}^{+3}$ ratio. The average $\mathrm{Fe}^{+2} / \mathrm{Fe}^{+3}$ steady state ratio over 80 hours of melter operation was 0.54 . It should be noted that some of the samples from

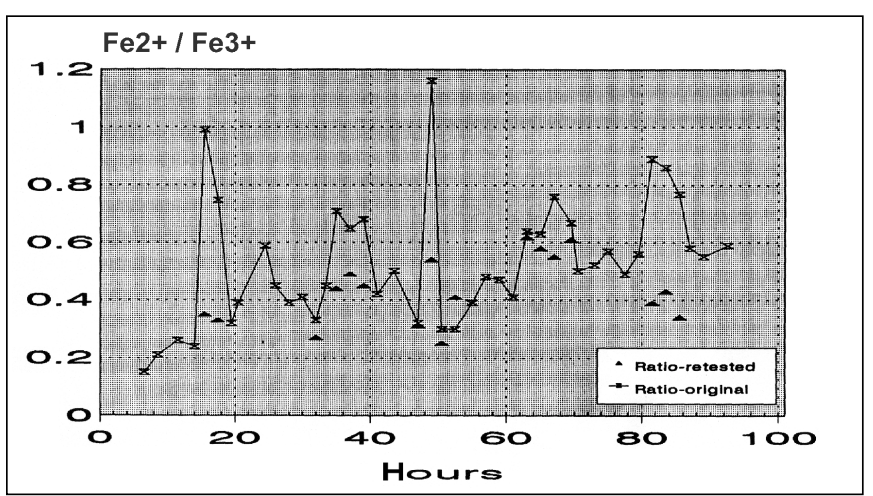

Figure E-4. Redox Ratio vs. Time the A\&PC Lab were sent back for reanalysis due to the $\mathrm{Fe}^{+2} / \mathrm{Fe}^{+3}$ ratio results being unexpectedly high or low. Different samples were submitted from the same airlift for reanalysis. The retested samples seemed to be prototypical of the trend and were plotted versus time. It should be noted that the retested $\mathrm{Fe}^{+2} / \mathrm{Fe}^{+3}$ ratios are represented by different symbols on Figure E-4 and the average includes the retested $\mathrm{Fe}^{+2} / \mathrm{Fe}^{+3}$ ratios. The redox data point for Run 1-05 is shown in Figure 18 of Section 5.3.1. 


\subsubsection{Internal Glass Temperature}

The internal glass pool temperature for Run 1-05 remained fairly consistent throughout the entire melter operation. The operating temperature ranged between $1,100^{\circ} \mathrm{C}$ and $1,165^{\circ} \mathrm{C}$, with a few exceptions. These exceptions were due to the melter power being off approximately six times during melter operation. This would explain the few data points that are above and below the operating range. Figure E-5 shows the internal glass pool temperature plotted over time.

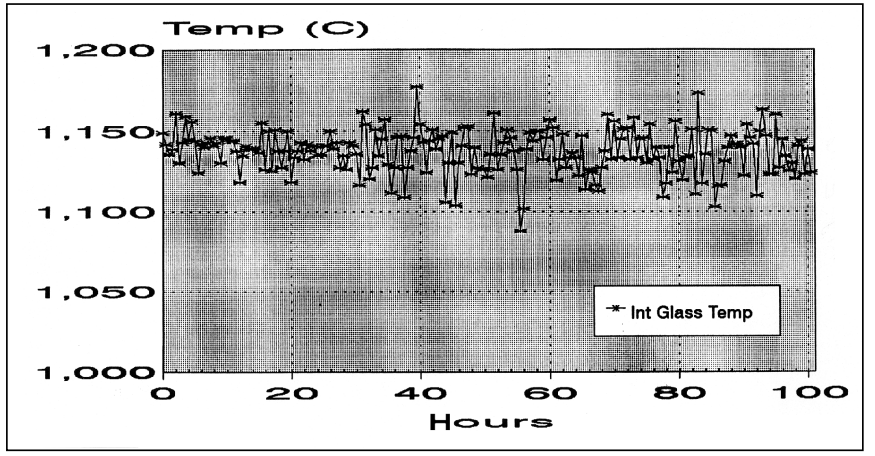

Figure E-5. Internal Glass Pool Temperature vs.Time

\subsubsection{Melter Power}

The melter power is plotted over time in Figure E-6. This graph indicates the average electrode power ranged between 5 and $15 \mathrm{~kW}$. Some of the points out of the operating range were due to powering down and powering up the melter.

\subsection{Summary}

The results of Run 1-05 demonstrated that an IFO of 2.34 corresponded to an average $\mathrm{Fe}^{+2} / \mathrm{Fe}^{+3}$ ratio of 0.54 in the melter during the 100 hours of melter operation. The overall variation to the major com-

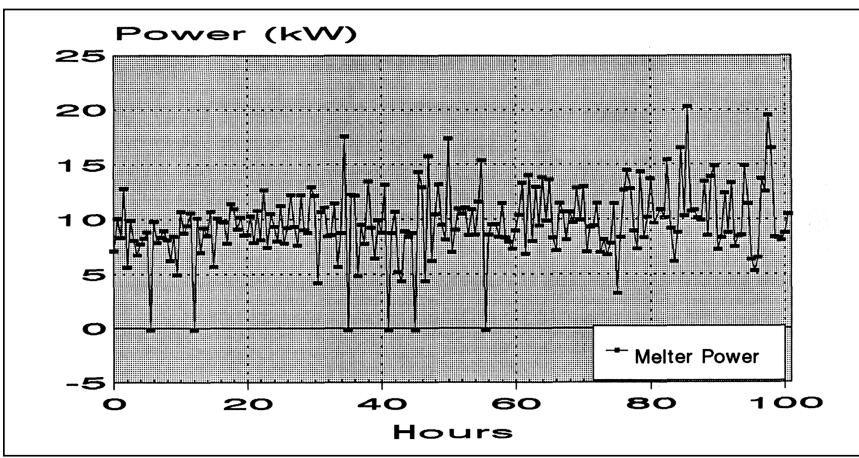

Figure E-6. Melter Power vs. Time ponents in the glass melt for Run 1-05 indicated that, except for $\mathrm{B}_{2} \mathrm{O}_{3}$ and $\mathrm{K}_{2} \mathrm{O}$, the slurry composition was similar to the airlift glass. The $\mathrm{Fe}^{+2} / \mathrm{Fe}^{+3}$ ratio information obtained in this run will be utilized in the Redox Forecasting Model that will predict the vitrification process. 


\section{APPENDIX F:}

\subsection{SVS-III RUN 1-06}

\subsection{Objectives}

SVS-III Run 1-06 concentrated on the following objectives:

- Targeting a redox ratio of 0.2

- Preparing enough feed, based on the Reference 6 target glass composition, to produce $720 \mathrm{~kg}$ of glass.

\subsection{Feed Preparation}

The waste simulant recipe for Run 1-06 was similar to previous runs. The chemicals were added in the sequence shown in Table 3 of Section 4.0. Four drums of ferric hydroxide were used in the chemical addition. The consistency of these drums, all from the same lot number, varied from so thick and lumpy that dilution with water was necessary in order to pump the chemical, to thin and separated with a layer of clear liquid on top. This variation may be due to exposure of the drums to temperature extremes during shipping. As the concentration of iron analyzed in the final slurry is within the acceptable range of the target, the varied rheology of the ferric hydroxide is not considered to present a problem.

The SMT volume measured by the level probe after the waste simulant chemical additions was 1,077 L, with a density of $1.23 \mathrm{~kg} / \mathrm{L}$. After transfer to the FHT, the volume was $1,079 \mathrm{~L}$ and the density was $1.12 \mathrm{~kg} / \mathrm{L}$. The high-density reading in the SMT is attributed to a blockage in the level probe resulting in higher-than-actual probe readings. The density measured in the FHT is the accurate reading.

The glass-former recipe for SVS-III Run 1-06 was also similar to previous runs. Chemicals were added in the order shown in Table 4 of Section 4.0. The SMT volume, as measured by the level probe after the glass-former chemical additions, was $880 \mathrm{~L}$, with a density of $1.44 \mathrm{~kg} / \mathrm{L}$.

After the waste simulant was transferred to the FHT, it was boiled down from 1,079 L to $824 \mathrm{~L}$. The post-boil down density was $1.28 \mathrm{~kg} / \mathrm{L}$.

Glass-former chemicals were added to the SMT and then transferred to the FHT to mix with the waste simulant. The volume of the glass-formers before transfer was 879.71 , with a density of $1.44 \mathrm{~kg} / \mathrm{l}$. As the glass-formers are transferred to the FHT and added to the concentrated waste simulant, the $\mathrm{HNO}_{3}$ in the glass-formers reacts with the $\mathrm{NaNO}_{2}$ in the waste simulant to generate $\mathrm{NO}_{\mathrm{x}}$ according to the reactions shown below.

$$
\begin{aligned}
& \mathrm{NaNO}_{2}+\mathrm{HNO}_{3} \rightarrow \mathrm{NaNO}_{3}+\mathrm{HNO}_{2} \\
& 3 \mathrm{HNO}_{2} \rightarrow \mathrm{H}^{+}+\mathrm{NO}_{3}+2 \mathrm{NO}^{-}+\mathrm{H}_{2} \mathrm{O}
\end{aligned}
$$


In Run 1-06, the amount of nitrate lost as a result of this reaction was calculated as $0.777 \mathrm{~kg}$ from the $\mathrm{NO}_{\mathrm{x}}$ measurements taken during the transfer. After the transfer, the volume in the FHT was 1,688 L, with a density of $1.35 \mathrm{~kg} / \mathrm{L}$.

The amount of sugar to be added to the feed as a reductant was determined by the amount of nitrates in the slurry and confirmed by the Vitrification Lab DSRT of crucible melts. From these data, a target IFO is selected to produce glass with the desired redox characteristics. The IFO formula is:

$$
\mathrm{IFO}=\mathrm{NO}_{3}(1-\mathrm{TS}) / \mathrm{TOC}
$$

where $\mathrm{NO}_{3}=$ nitrate concentration, TS = solids fraction, and TOC $=$ total organic carbon. For Run 1-06, $148 \mathrm{~kg}$ of sugar (62.3 kg TOC) was added to target a ferrous-to-ferric ratio of 0.20 in the SVS-III melter. DSRT results on post-slurry sugar show an average $\mathrm{Fe}^{+2} / \mathrm{Fe}^{+3}$ ratio of 0.20 .

The nitrate balance for Run 1-06 is shown in Table F-1. The amounts were unchanged from Run 1-05. Post-sugar slurry volume, as measured by the level probe in the FHT, was 1,779 L; the density of the final slurry was $1.36 \mathrm{~kg} / \mathrm{L}$; the oxide loading was $0.28 \mathrm{~kg} / \mathrm{kg}(0.381 \mathrm{~kg}$ glass per L of slurry); and the solids fraction was 0.47 . The target IFO used for calculating the amount of sugar was 2.45 . The analyzed IFO was 2.38 .

Table F-1. Nitrate Balance

\begin{tabular}{|c|c|c|c|c|c|c|}
\hline $\begin{array}{l}\text { Nitrate } \\
\text { Sources }\end{array}$ & $\begin{array}{c}\text { Simulant } \\
\text { (kg) }\end{array}$ & (kg) & $\begin{array}{l}\text { Glass- } \\
\text { Former (kg) }\end{array}$ & (kg) & $\begin{array}{l}\text { Slurry } \\
\text { (kg) }\end{array}$ & (kg) \\
\hline & $\begin{array}{l}\text { Amount } \\
\text { Added }\end{array}$ & $\begin{array}{l}\text { Amount } \\
\mathrm{NO}_{3}\end{array}$ & $\begin{array}{l}\text { Amount } \\
\text { Added }\end{array}$ & $\begin{array}{l}\text { Amount } \\
\mathrm{NO}_{3}\end{array}$ & $\begin{array}{l}\text { Amount } \\
\text { Added }\end{array}$ & $\begin{array}{l}\text { Amount } \\
\mathrm{NO}_{3}\end{array}$ \\
\hline Nitric Acid & 0.00 & 0.00 & 680.10 & 234.26 & 680.10 & 234.26 \\
\hline Sodium nitrate & 16.78 & 12.24 & 0.00 & 0.00 & 16.78 & 12.24 \\
\hline Sodium Nitrite & 25.92 & 0.00 & 0.00 & 0.00 & 25.92 & $7.75^{*}$ \\
\hline Zirconyl Oxynitrate & 78.28 & 31.69 & 47.40 & 19.19 & 125.68 & 50.88 \\
\hline $\begin{array}{l}\text { Total } \mathrm{NO}_{3} \\
\text { Total } \mathrm{NO}_{2}\end{array}$ & & 51.68 & & 253.45 & & $\begin{array}{l}305.13 \\
17.28\end{array}$ \\
\hline
\end{tabular}

* includes $\mathrm{NaNO}_{2}$ converted to $\mathrm{NO}_{3}$ per reactions ( 1 ) and ( 2 )

The waste simulant, glass-formers, and final slurry were analyzed by ICP in the A\&PC Lab. In Table F-2, the target oxide compositions for the waste simulant, glass-formers, and final slurry are compared with the analyzed oxide compositions. The analyzed amounts of $\mathrm{SiO}_{2}$ in the final slurry, waste simulant, and glass-formers were $8 \%, 8 \%$, and $7 \%$ higher than the target values, respectively. $\mathrm{B}_{2} \mathrm{O}_{3}$ was $12 \%$ below target in the final slurry. In the analysis of the glass-formers, all components were within the acceptable range of the target. 
Table F-2. ICP Analysis of Oxide Composition (in kg)

\begin{tabular}{|c|c|c|c|c|c|c|c|c|c|c|c|c|}
\hline Oxides & $\begin{array}{c}\text { Target } \\
\text { Glass } \\
\text { (kg) }\end{array}$ & $\begin{array}{c}\text { Analyzed } \\
\text { Slurry } \\
\text { (kg) }\end{array}$ & $\begin{array}{l}\text { Diff. } \\
\text { (kg) }\end{array}$ & \% Diff. & $\begin{array}{c}\text { Target } \\
\text { Simulant } \\
\quad(k g)\end{array}$ & $\begin{array}{c}\text { Analyzed } \\
\text { Simulant } \\
\text { (kg) }\end{array}$ & $\begin{array}{r}\text { Diff. } \\
\text { (kg) }\end{array}$ & $\%$ Diff & $\begin{array}{c}\text { Target } \\
\text { Glass- } \\
\text { Formers } \\
\text { (kg) }\end{array}$ & $\begin{array}{l}\text { Analyzed } \\
\text { Glass- } \\
\text { Formers } \\
\text { (kg) }\end{array}$ & $\begin{array}{l}\text { Diff. } \\
\text { (kg) }\end{array}$ & $\%$ Diff. \\
\hline $\mathrm{Al}_{2} \mathrm{O}_{3}$ & 43.20 & 42.01 & 1.19 & 2.76 & 22.39 & 22.11 & 0.28 & 1.25 & 20.81 & 20.94 & -0.13 & -0.64 \\
\hline $\mathrm{B}_{2} \mathrm{O}_{3}$ & 92.81 & 81.18 & 11.63 & 12.53 & 0.43 & 1.13 & -0.70 & -161.8 & 92.38 & 89.60 & 2.78 & 3.01 \\
\hline $\mathrm{Fe}_{2} \mathrm{O}_{3}$ & 86.54 & 81.32 & 5.22 & 6.03 & 86.54 & 81.04 & 5.50 & 6.36 & 0.00 & 1.23 & -1.23 & \\
\hline $\mathrm{K}_{2} \mathrm{O}$ & 36.00 & 31.85 & 4.15 & 11.52 & 29.30 & 25.46 & 3.84 & 13.12 & 6.70 & 6.46 & 0.24 & 3.56 \\
\hline $\mathrm{Li}_{2} \mathrm{O}$ & 26.71 & 25.42 & 1.29 & 4.82 & & 0.06 & -0.06 & & 26.71 & 27.02 & -0.31 & -1.14 \\
\hline $\mathrm{MgO}$ & 6.41 & 6.20 & 0.21 & 3.20 & 1.30 & 1.37 & -0.08 & -5.82 & 5.11 & 5.07 & 0.04 & 0.75 \\
\hline $\mathrm{MnO}$ & 5.90 & 5.85 & 0.06 & 0.96 & 4.10 & 4.13 & -0.03 & -0.72 & 1.80 & 1.78 & 0.02 & 0.93 \\
\hline $\mathrm{Na}_{2} \mathrm{O}$ & 57.60 & 55.19 & 2.41 & 4.18 & 36.00 & 32.74 & 3.26 & 9.06 & 21.60 & 21.91 & -0.31 & -1.44 \\
\hline $\mathrm{NiO}$ & 1.80 & 1.68 & 0.12 & 6.59 & 1.80 & 1.65 & 0.15 & 8.17 & & 0.03 & -0.03 & \\
\hline $\mathrm{P}_{2} \mathrm{O}_{5}$ & 8.64 & 8.47 & 0.17 & 1.98 & 8.64 & 8.26 & 0.38 & 4.44 & 0.00 & 0.41 & -0.41 & \\
\hline $\mathrm{SO}_{3}$ & 1.66 & 2.31 & -0.66 & -39.56 & 1.66 & 2.20 & -0.55 & -33.15 & 0.00 & 0.18 & -0.18 & \\
\hline $\mathrm{SiO}_{2}$ & 310.68 & 318.97 & -8.29 & -2.67 & 82.94 & 91.15 & -8.20 & -9.89 & 227.16 & 242.59 & -15.43 & -6.79 \\
\hline $\mathrm{TiO}_{2}$ & 5.76 & 5.40 & 0.36 & 6.21 & 2.88 & 2.95 & -0.07 & -2.31 & 2.88 & 2.95 & -0.07 & -2.35 \\
\hline $\mathrm{ZrO}_{2}$ & 24.70 & 22.84 & 1.85 & 7.50 & 15.34 & 14.23 & 1.11 & 7.21 & 9.29 & 9.08 & 0.21 & 2.26 \\
\hline Others & 10.45 & 8.74 & & & 10.88 & 7.10 & & & 0.00 & 1.15 & & \\
\hline Total & 718.85 & 697.45 & & & 304.20 & 295.58 & & & 414.43 & 430.39 & & \\
\hline \multicolumn{4}{|c|}{ Target Volume -- Final Slurry } & $000.00 \mathrm{~L}$ & \multicolumn{4}{|c|}{ Target Oxide Loading } & $0.70 \mathrm{hg} / \mathrm{Kg}$ & & & \\
\hline \multicolumn{3}{|c|}{ Target Amount of Glass } & \multicolumn{2}{|c|}{$720.00 \mathrm{~kg}$} & \multicolumn{4}{|c|}{ Volume of Simulant } & $823.90 \mathrm{~L}$ & & & \\
\hline \multicolumn{3}{|c|}{ Volume of Glass-Formers } & \multicolumn{2}{|c|}{$879.70 \mathrm{~L}$} & \multicolumn{4}{|c|}{ Volume of Pre-Sugar Slurry } & $1,687.80 \mathrm{~L}$ & & & \\
\hline \multicolumn{3}{|c|}{ Volume of Final Slurry } & \multicolumn{2}{|c|}{$1,778.90 \mathrm{~L}$} & \multicolumn{4}{|c|}{ Oxide Loading } & $392.07 \mathrm{~g} / \mathrm{L}$ & & & \\
\hline \multicolumn{3}{|c|}{ Final Density } & \multicolumn{2}{|c|}{$1.33 \mathrm{~kg} / \mathrm{L}$} & & & & & & & & \\
\hline
\end{tabular}

A\&PC $\mathrm{Lab}$ analyses of $\mathrm{CaO}$ and $\mathrm{SO}_{3}$ in the waste simulant have been consistently high: $\sim 10 \%$ and $\sim 30 \%$, respectively. Analysis of the ferric hydroxide added to the waste simulant revealed $137 \mathrm{ppm}$ sulfur and 531 ppm Ca, which translates to an additional $0.29 \mathrm{~kg} \mathrm{SO}_{3}$ and $0.63 \mathrm{~kg} \mathrm{CaO}$ in the $845 \mathrm{~kg}$ of ferric hydroxide added to each waste simulant batch. Adding these values to the simulant target values brings the analyses to $5.5 \%$ below target for the $\mathrm{CaO}$ and $12.8 \%$ above target for $\mathrm{SO}_{3}$. The target values will be readjusted to account for these additional amounts.

The properties of the slurries prepared during SVS-III Run 1-06 are summarized in Table F-3. The analyzed amount of nitrate $(261.7 \mathrm{~kg})$ is considerably lower than the targeted amount $(305 \mathrm{~kg})$. The nitrates contributed by the zirconyl oxynitrate in both the waste simulant and the glass-formers cannot be analyzed by the A\&PC Lab. By calculations made from the target $\mathrm{NO}_{3}$ values, the amount of $\mathrm{NO}_{3}$ in the final slurry contributed by the zirconyl nitrate was found to be $24.8 \mathrm{~kg}$. Adding this to the analyzed total $\mathrm{NO}_{3}$ brings the analyzed $\mathrm{NO}_{3}$ amount to $286.5 \mathrm{~kg}$, which is $6.1 \%$ below the target of $305 \mathrm{~kg}$ total nitrate. TOC was analyzed as $63.7 \mathrm{~kg}, 2.2 \%$ above the target of $62.3 \mathrm{~kg}$. 
Table F-3. Properties of the Slurries

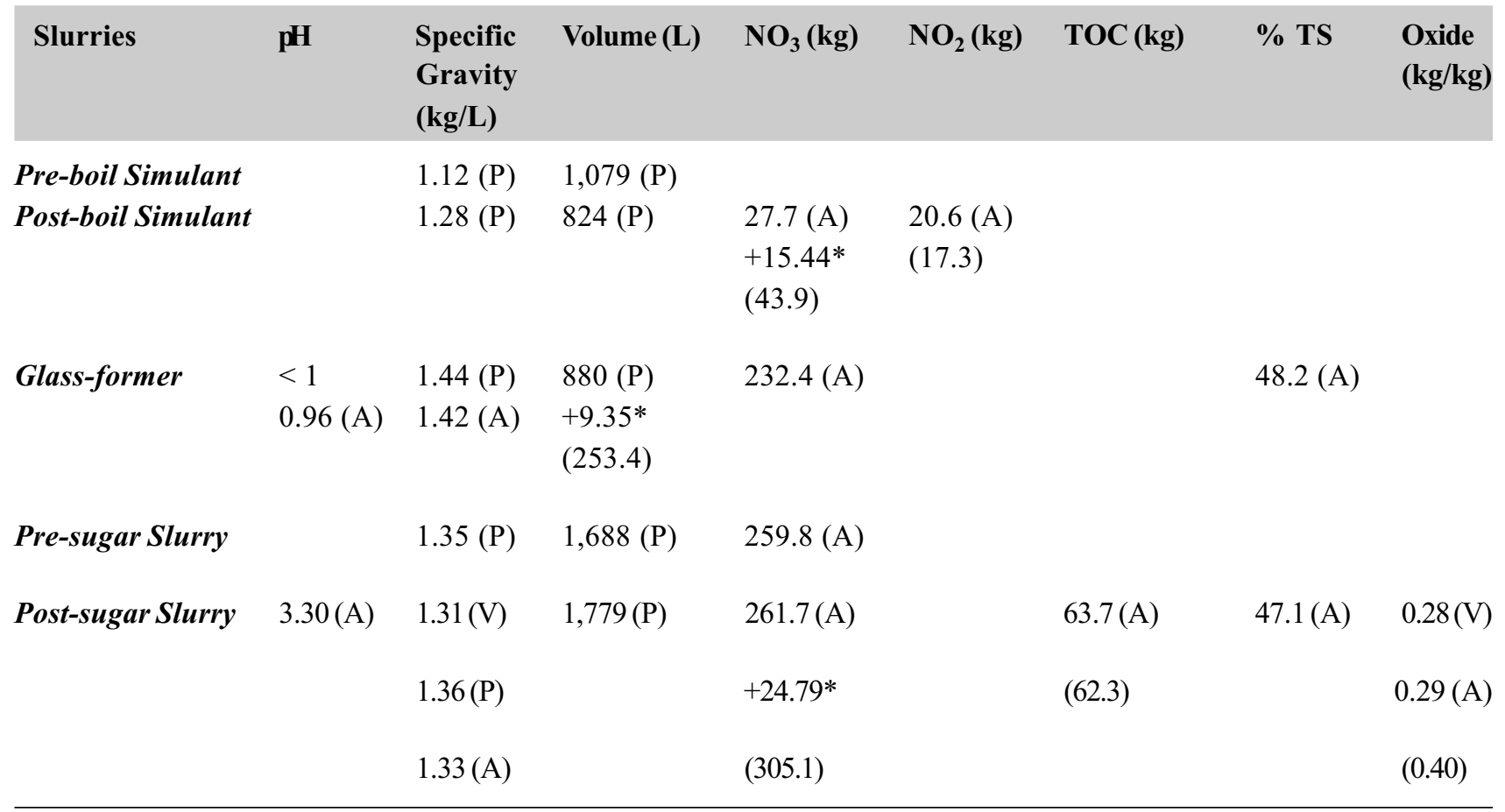

$(\mathrm{A})=$ A\&PC Lab, $(\mathrm{V})=$ Vitrification Lab, $(\mathrm{P})=$ Level Probe, ()$=$ Target Amounts

$* \mathrm{NO}_{3}$ from zirconyl nitrate not measurable in A\&PC Lab analysis

\subsection{Melter Operation}

The feed rate, cold cap coverage, and plenum temperature are interdependent. At the beginning of the run, the feed rate is high to establish a cold cap over the glass melt. Once the cold cap is established, the feed rate is reduced to the target range of 15 to $20 \mathrm{~L} / \mathrm{hr}$. The extent of the cold cap determines the plenum temperature, with $\sim 85 \%$ cold cap coverage maintaining a plenum temperature in the target range of $500^{\circ}$ to $600^{\circ} \mathrm{C}$.

During the run the feed rate, shown in Figure F-1, was initiated at 25 to $30 \mathrm{~L} / \mathrm{hr}$, decreased to average in the target range within the first ten hours of the run, and remained steady throughout. The plenum temperature, shown in Figure F-2, decreased from $900^{\circ} \mathrm{C}$ to $\sim 600^{\circ} \mathrm{C}$ during the first five hours of the run, then stabilized around $500^{\circ}$ to $600^{\circ} \mathrm{C}$ for the remainder of the run.

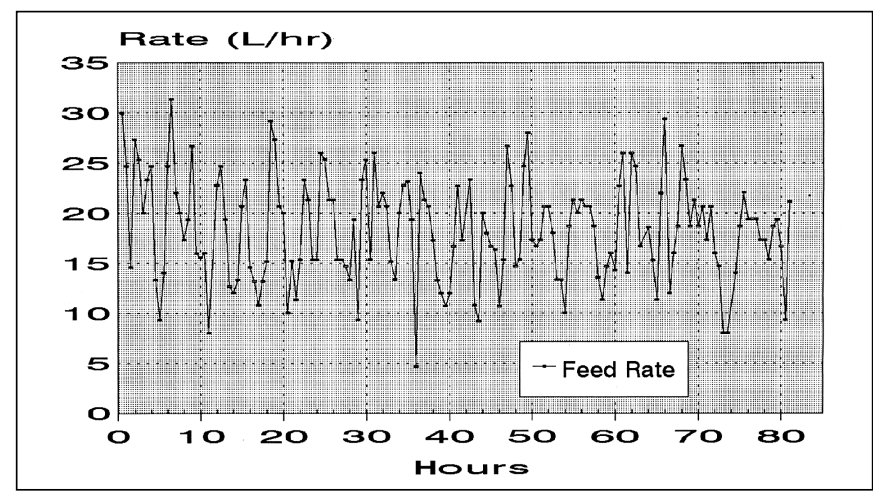

Figure F-1. Feed Rate vs. Time

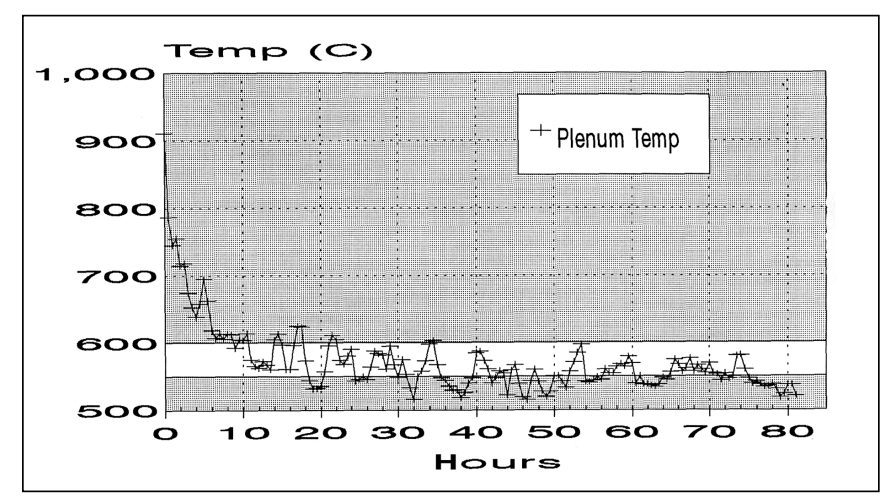

Figure F-2. Plenum Temperature vs. Time 


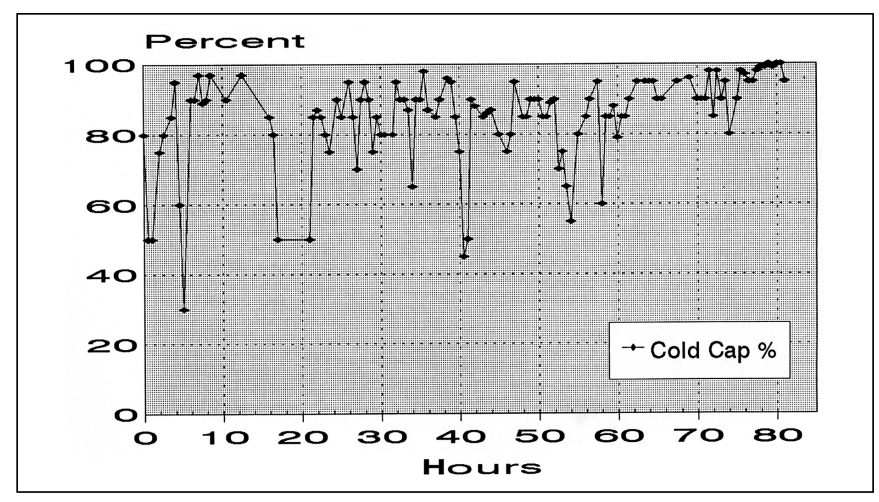

Figure F-3. Percent Cold Cap Coverage vs. Time

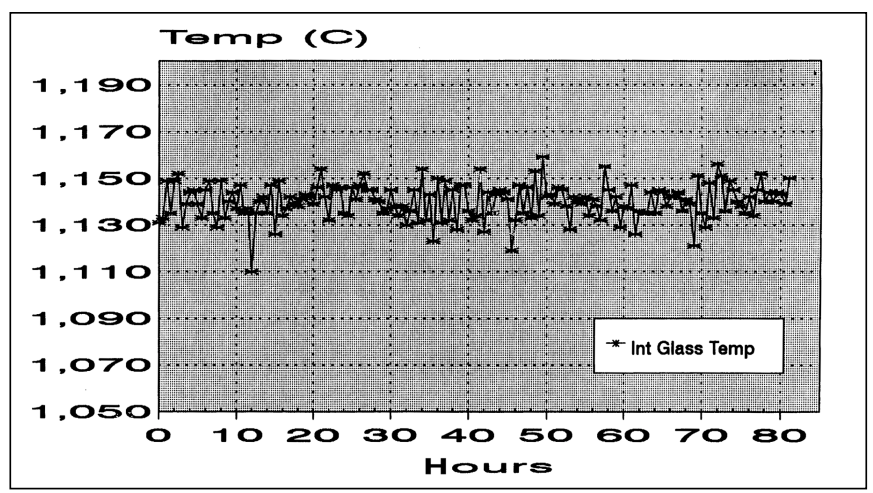

Figure F-4. Internal Glass Pool Temperature vs. Time

Figure F-3 shows cold cap coverage as percent coverage vs. time. Coverage was irregular, varying between 50 and $100 \%$ with only short periods of stability. Between 20 and 40 hours into the run, the cold cap was fairly stable, averaging around $85 \%$ coverage. Another period of fairly consistent coverage was the last 20 hours of the run where the average was $\sim 95 \%$, with $100 \%$ coverage during the final four hours. The internal glass temperature is shown in Figure F-4. The temperature was maintained within $20^{\circ} \mathrm{C}$ throughout the 81 hours of melter operation, ranging between $1,130^{\circ}$ and $1,150^{\circ} \mathrm{C}$. Melter power, as shown in Figure F-5, averaged around $10 \mathrm{~kW}$ for the entire run.

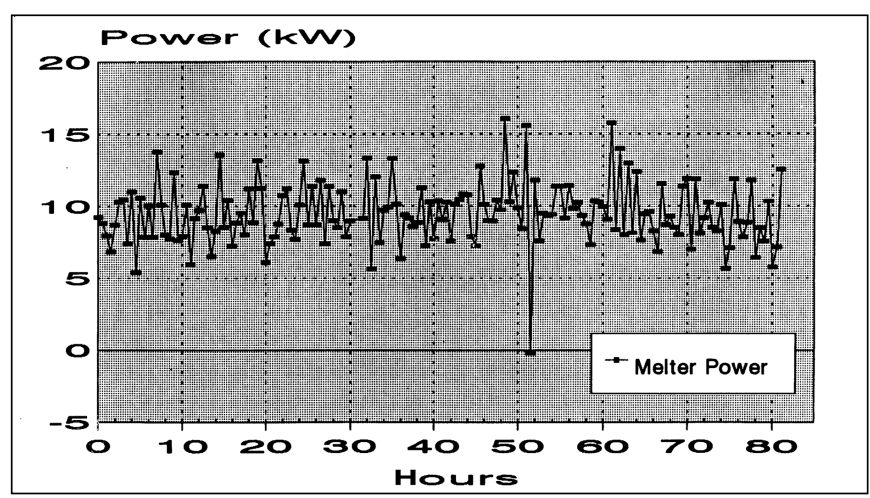

Figure F-5. Melter Power vs. Time

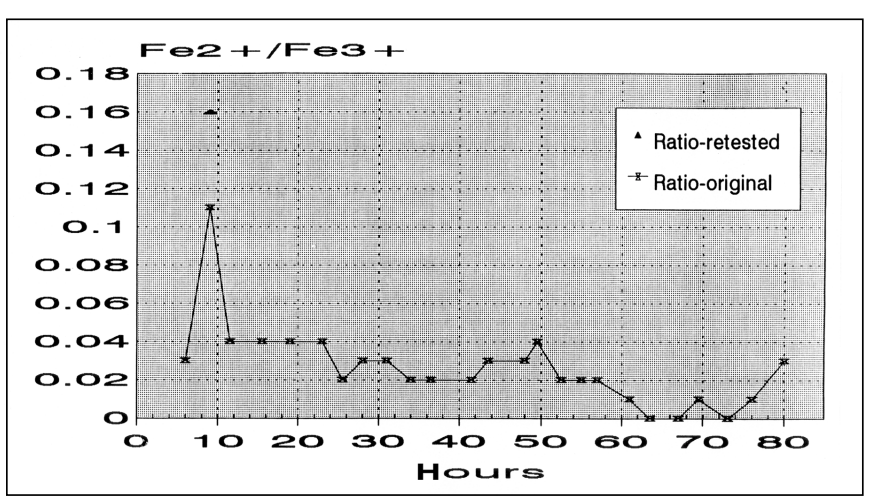

Figure F-6. Redox Ratio vs. Time

The target ferrous-to-ferric ratio for SVS-III Run 1-06 was 0.2. The four airlift glass samples taken before the melter was shut down to repair the discharge had an average $\mathrm{Fe}^{+2} / \mathrm{Fe}^{+3}$ ratio of 0.025 . Figure F-6 shows the $\mathrm{Fe}^{+2} / \mathrm{Fe}^{+3}$ ratio of the glass produced in the melter, after the run was recommenced, as a function of melter operation time. The ratio was well below the target throughout the run. The $\mathrm{Fe}^{+2} / \mathrm{Fe}^{+3}$ ratio remained consistent at 0.02 to 0.04 during the period of 10 to 60 hours into the run. During the last 20 hours, the ratio varied from 0.0 to 0.01 .

Because of the clogged discharge and the subsequent mechanical removal methods, it is possible that air was leaking into the melter during this run from a warped plate in the bellows below the discharge and, as a result, the atmosphere over the glass melt could not attain steady state conditions. A steady inleakage of air could have contributed to the highly oxidizing nature of the glass melt, but was probably not a substantial influence. The bellows connecting the discharge to the stainless steel drum were repaired and modified to ensure a tight seal. 
Another possible redox influence arises from the fact that, in general for SVS-III as the plenum temperature increases, the glass melt becomes more oxidized as the cold cap decreases in size. In Run 1-06, however, this correlation is not strong. As shown in Figure F-7, between 30 and 35 hours and 40 and 50 hours the Fe $/ \mathrm{Fe}^{+3}$ ratio increased slightly along with a lowering of the plenum temperature, but for the majority of the run this relationship is elusive. The average plenum temperature was $559^{\circ} \mathrm{C}$; only slightly higher than the previous runs.

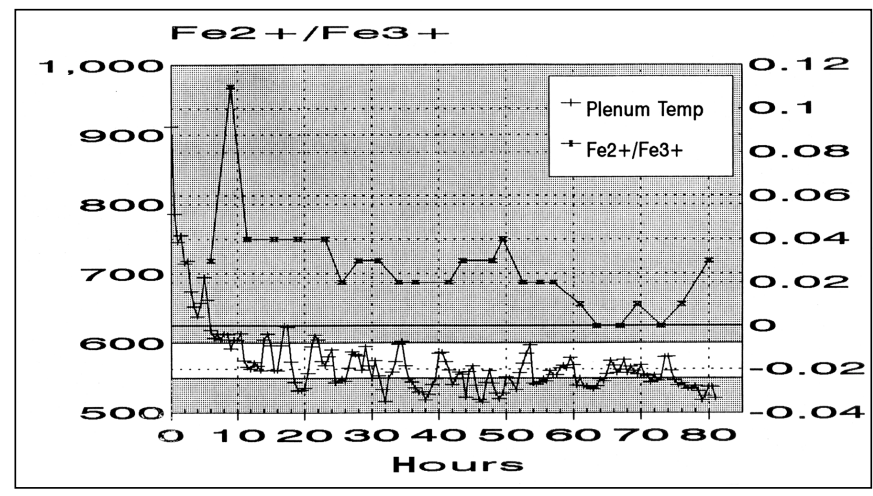

Figure F-7. Redox Ratio and Plenum Temperature vs. Time

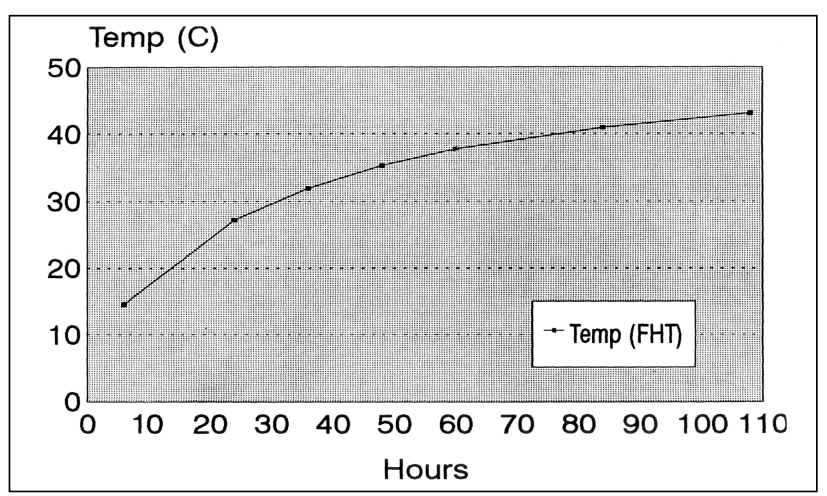

Figure F-8. FHT Temperature vs. Time

A third avenue of investigation lies in the possibility that the chemistry of the slurry changed in some manner during the two weeks that the slurry remained in the FHT with continuous agitation while the melter discharge was being repaired. Prior to melter shutdown, the $\mathrm{Fe}^{+2} / \mathrm{Fe}^{+3}$ ratio of several airlift glass samples and the Vitrification Lab slurry melt glasses were approximately 0.2 . The first two slurry samples and the second airlift glass taken after the run was restarted had $\mathrm{Fe}^{+2} / \mathrm{Fe}^{+3}$ ratios of approximately 0.1 . The ferrous-to-ferric ratios of the remaining slurry melt and airlift glasses were all less than 0.06 .

The temperatures in the FHT during the 13 days that the discharge was being repaired are shown in Figure F-8 as a function of time. After the glass-formers were added to the waste simulant, the FHT temperature was $19.2^{\circ} \mathrm{C}$. Over the next five days, the temperature increased to a maximum of $44.6^{\circ} \mathrm{C}$ and remained around that temperature through the beginning of SVS-III Run 1-06 on May 1, 1995. It is possible that the two-week residence of the slurry in the FHT with continuous agitation and elevated temperatures encouraged reactions that resulted in a sufficient depletion in sugar content to move the glass to the oxidizing end of the redox curve.

\subsection{Summary}

The target for SVS-III Run 1-06 was to supply a redox data point in the vicinity of 0.2 on the Redox Forecasting Model curve. The redox data point for Run 1-06 is shown in Figure 17 of Section 5.3.1. The sugar addition was determined based on this forecasting model and the results of SVS-III Run 1-05. SVS-III Run 1-06 was anomalous in that the post-sugar slurry was held in the FHT for two weeks prior to initiation of feed to the melter and the discharge area had been chiseled out after it plugged with glass when the run was first started. The ferrous-to-ferric ratio of the melter glass ranged from 0.00 to 0.04 , much more oxidizing than the target predicted by the Redox Forecasting Model. The discharge area may have lost refractory or sustained some other damage during repair that resulted in air in-leakage during melter operation. It is unlikely, however, that air in-leakage significantly influenced the redox conditions in the melter. 
The highly oxidized nature of the glass melt is probably the result of a change in the composition of the feed slurry with regard to the amount of total carbon. During the two weeks that the slurry was held in the FHT, the temperature in the tank increased from $19^{\circ} \mathrm{C}$, when the glass-formers were added to the waste simulant, to approximately $45^{\circ} \mathrm{C}$ after five days and remained at the higher temperature through the melter restart; the FHT was continuously agitated during this period. It is likely that the elevated temperatures, continuous agitation, and long residence time in the FHT favored the occurrence of reactions that resulted in a decrease in the total carbon sufficient to shift the melter conditions to the oxidizing portion of the Redox Forecasting Model curve.

In SVS-III Run 1-06, the feed slurry recipe, based on the Reference 6 target glass composition, was calculated to produce $720 \mathrm{~kg}$ of glass with a Fe $\mathrm{Fe}^{+2} / \mathrm{Fe}^{+3}$ ratio of 0.2 . Relative to SVS-III Run 1-05, $4 \mathrm{~kg}$ less sugar was added and the nitric balance was unchanged. Heel simulation was not included in the feed preparation cycle.

Feed make-up was completed on April 18, 1995 and the feed was started on April 19, 1995. During the initial part of the run, the discharge port of the melter became plugged with glass and a glass pool accumulated in the discharge area. The melter was then stopped. At that time it was estimated that $\sim 90 \mathrm{~kg}$ of glass was in the discharge area. Four airlift samples were collected before the melter feed was stopped.

The glass was cleared from the discharge area of the melter by chipping out the cooled glass and then reheating the discharge chamber to allow the remaining glass to flow out. After several repeats of this sequence, all the glass was removed. SVS-III Run 1-06 was restarted on May 1, 1995. 
This page intentionally blank. 


\section{APPENDIX G:}

\subsection{SVS-III RUN 2-01}

\subsection{Objectives}

SVS-III Run 2-01 concentrated on the following objectives:

- Targeting an IFO of 3.0 for the Redox Forecasting Model

- Observing melter operation for the duration of feeding to note any conditions that may contribute to foaming in the melter

- Utilizing the Hydragard ${ }^{\circledR}$ sampling system to obtain samples from the FHT

- Preparing enough feed to produce $720 \mathrm{~kg}$ of glass.

\subsection{Feed Preparation}

The feed preparation for the SVS-III operation is comprised of several necessary steps for the production of acceptable slurry feed for vitrification in the SVS-III melter. The main steps for the production of acceptable slurry feed are listed below:

- Addition of chemicals to the SMT to make up the waste simulant

- Transfer the waste simulant from the SMT to the FHT

- Pull process control samples of the contents of the FHT (waste simulant) before boiling

- Boil the contents of the FHT to remove excess water

- Pull process control samples of the FHT (waste simulant) after boiling the contents

- Addition of chemicals to the SMT to make up the glass-formers

- Pull process control samples of the SMT (glass-formers)

- Lower the temperature of the FHT to $<30^{\circ} \mathrm{C}$ for the addition of the contents of the SMT to the FHT

- Pull process control samples of the FHT (slurry)

- Addition of sugar to the FHT based on analysis of the slurry samples pulled for process control

- Transfer contents from the FHT to the MFT on a batch basis (continuous feeding of the melter is maintained from the MFT).

The chemicals are added in the sequence shown in Tables 3 and 4 (see Section 4) to ensure that the waste simulant and glass-formers become homogeneous so that transferring the contents of the SMT to the FHT is possible. It should be noted that Run 2-01 was started with little or no heel present in the tanks. 
The waste simulant chemicals were added to the SMT. The first chemical added to the SMT was ferric hydroxide. This addition was successfully completed with no difficulties. However, it should be noted that an extra $11.28 \mathrm{~kg}$ of ferric hydroxide was added. The extra ferric hydroxide was $1.35 \%$ over the target amount to be added. This extra amount poses no problem, but greater care should be taken when adding chemicals. Any amount added that exceeds the target amounts specified could have an impact on the calculation of the final target oxide compositions.

The rest of the waste simulant chemicals were added in sequence per Table 3. Upon completion of the addition of chemicals for the waste simulant, the contents of the SMT were transferred via grinder to the FHT. Approximately $355 \mathrm{~L}$ of water had been added to the waste simulant to bring the final volume of the FHT to 1,400 L. The additions of water took place in the SMT and the FHT. It was believed, at the time, the totalizer was not registering the amount of water actually being put into the SMT. To resolve this problem, the waste simulant was transferred to the FHT and the volumes of the two tanks were compared. The volumes of the two tanks were consistent, but they did not agree with the amount read by the totalizer. It was decided that the tank level provided a representative volume so the difference between the initial and final volume of the tank was utilized as the indication of how much water had been added.

The contents of the FHT were boiled down. The final target volume for the waste simulant was $900 \mathrm{~L}$. Based on the initial and final volume of the FHT, approximately $619.8 \mathrm{~L}$ of water was boiled off. The final volume of the FHT was $780.2 \mathrm{~L}$.

The re-installation and testing of the Hydragard ${ }^{\circledR}$ sampling system (on the FHT) was completed during the final slurry preparation for SVS-III Run 1-06. The sampling system performed as expected when tested with the final slurry from Run 1-06. It should be noted that the sampling system plugged when it was utilized for sampling the post-boil waste simulant and pre-sugar slurry for Run 2-01. The pluggage of the post-boil waste simulant is believed to stem from the fact that an extra $119.8 \mathrm{~L}$ of water was removed during concentration of the waste simulant. The pluggage from the pre-sugar slurry happened after two Hydragard ${ }^{\mathbb{R}}$ samples were taken. This pluggage was believed to have stemmed from a slow leak that caused material to build up in the opening of the sample stream. In both cases (pluggage and the Hydragard ${ }^{\circledR}$ ), half full $60 \mathrm{~mL}$ bottles were taken in place of the Hydragard ${ }^{\circledR}$ samples.

To prepare for the glass-former addition to the FHT, the off-gas system was valved in and the temperatures of the SMT and the FHT were lowered to $24^{\circ} \mathrm{C}$ and $31.1^{\circ} \mathrm{C}$, respectively. The temperatures of these tanks were lowered in order to control anticipated $\mathrm{NO}_{\mathrm{x}}$ generation from the forementioned reactions. The off-gas system experienced a ten minute period where the incoming $\mathrm{NO}_{\mathrm{x}}$ was $10,000 \mathrm{ppm}$ or greater. The off-gas system responded to this peak by an increased injection rate of ammonia into the fluidized bed reactor.

The amount of sugar to be added to the FHT was determined to be $119.0 \mathrm{~kg}$. This calculation was based on a target IFO number of 3.0. and Vitrification Lab redox tests. The sugar was added, process control samples were taken, and the results were found to be acceptable.

The generation of $\mathrm{NO}_{\mathrm{x}}$ occurs in the FHT when glass-formers from the SMT are added to the concentrated waste simulant. The following reactions transpire upon the addition of the glass-formers:

$$
\begin{gathered}
\mathrm{NaNO}_{2}+\mathrm{HNO}_{3} \rightarrow \mathrm{NaNO}_{3}+\mathrm{HNO}_{2} \\
3 \mathrm{HNO}_{2} \rightarrow \mathrm{H}^{+}+\mathrm{NO}_{3}{ }^{-}+2 \mathrm{NO}+\mathrm{H}_{2} \mathrm{O}
\end{gathered}
$$


A new recommendation has been made in this report to control the temperatures of both tanks at $30^{\circ} \mathrm{C}$ or lower. This recommendation was made in order to avoid entry $\mathrm{NO}_{\mathrm{x}}$ spikes to the off-gas system greater than 10,000 ppm as experienced in Run 1-06. There was also a trend noted with the $\mathrm{NO}_{\mathrm{x}}$ generation and the temperature of the FHT. It appears that if the temperature of the waste simulant is above $30^{\circ} \mathrm{C}$, the $\mathrm{NO}_{\mathrm{x}}$ spike entering the off-gas system endures for a longer period of time.

The amount of nitrates lost due to the addition of glass-formers to the waste simulant is approximately $1.84 \mathrm{~kg}$.

The target IFO for Run 2-01 was 3.08. This target IFO was selected to provide information about melter operation when melter feed is subjected to very oxidizing conditions. This IFO number was also selected as a possible bounding operational parameter for the melter.

The calculated amount of reductant that corresponded to an IFO of 3.0 was $119 \mathrm{~kg}$ of sugar. This sugar amount was determined by utilizing the IFO formula. The IFO formula utilizes data from the nitrate balance, mass fraction of total solids in the slurry, and total carbon concentration.

The nitrate balance is based on chemical components added in the waste simulant and glass-former additions that contribute nitrates to the final slurry. These calculated nitrate amounts from the chemical components appear in Table G-1.

Table G-1. Nitrate Balance

\begin{tabular}{|c|c|c|c|}
\hline Chemical Components & Simulant Addition (kg) & Glass-former Addition (kg) & Total Added to Slurry (kg) \\
\hline Nitric Acid (35 wt\%) & - & 680.10 & 680.10 \\
\hline Sodium Nitrite & 25.92 & - & 25.92 \\
\hline Sodium Nitrate & 16.78 & - & 16.78 \\
\hline Zirconyl Nitrate & 78.28 & 47.40 & 125.68 \\
\hline $\begin{array}{l}\text { Amount of Nitrate } \\
\text { Added from Chemical } \\
\text { Components (kg) }\end{array}$ & $\begin{array}{l}\text { Nitrate Added to the } \\
\text { Simulant from Chemical } \\
\text { Components }(\mathrm{kg})\end{array}$ & $\begin{array}{l}\text { Nitrate Added to the } \\
\text { Glass-former from Chemi- } \\
\text { cal Components (kg) }\end{array}$ & $\begin{array}{l}\text { Total Amount of Nitrate } \\
\text { Added to the Final Slurry } \\
\text { (kg) }\end{array}$ \\
\hline Nitric acid (35 wt\%) & - & 234.26 & 234.26 \\
\hline Sodium Nitrite* & - & - & 7.75 \\
\hline Sodium Nitrate & 12.24 & - & 12.24 \\
\hline Zirconyl Nitrate ${ }^{* *}$ & 31.69 & 19.19 & 50.88 \\
\hline Total Nitrate & 43.93 & 253.45 & 305.13 \\
\hline Total Nitrite* & 17.28 & & \\
\hline
\end{tabular}

* $0.299 \mathrm{~kg}$ of nitrate per $\mathrm{kg}$ of sodium nitrite (per reactions in this section)

** contains $42.5 \mathrm{wt} \%$ zirconyl nitrate and $21.1 \mathrm{wt} \%$ nitric acid

Since the slurry being utilized for this run was more oxidizing than any of the slurries utilized for previous runs, it was decided to make five 250 -g batches of slurry containing different sugar amounts. 
The analyzed IFO was recalculated based on the A\&PC Lab results of the final slurry. The IFO was 2.74 compared to an IFO of 3.08 (sugar addition basis). The results indicated that the IFOs are slightly different; this may be due to the volumes of the FHT utilized in the calculation of the components that make up the IFO itself. There were no volumes recorded for the post-sugar slurry for the FHT, so a calculated volume was utilized. This calculated volume was based on the pre-sugar volume of the FHT and the volume that would be displaced by the weight of the sugar being added to the FHT. The volume being displaced by the sugar was calculated by taking the total kilograms added to the FHT and dividing this number by its specific gravity $\left(1.588\right.$ at $\left.15^{\circ} \mathrm{C}\right)$. Utilizing these numbers, the volume displaced by the sugar was $74.93 \mathrm{~L}$. The final volume of the post-sugar slurry was $1785 \mathrm{~L}$.

Other possible contributors to the difference between the two IFOs are the analyzed nitrate and the total organic carbon results from the A\&PC Lab. The analyzed nitrate for the final slurry was $283.67 \mathrm{~kg}$. This does not include the nitrate coming from the zirconyl nitrate solution. The A\&PC Lab cannot analyze for this component due to its complexing nature in the slurry. The calculated amount of nitrate coming from the zirconyl nitrate must be added to the analyzed nitrate value. The resulting nitrate value from the addition of these two numbers was $308.44 \mathrm{~kg}$, which exceeded the target amount by $1.08 \%$. The analyzed total organic carbon for the final slurry was $55.02 \mathrm{~kg}$, which also exceeded the target of $9.81 \%$. These results are presented in Table G-2, along with other properties of the slurries prepared for Run 2-01.

Table G-2. Properties of the Slurries Prepared

\begin{tabular}{|c|c|c|c|c|c|c|c|}
\hline Slurries & pH & $\begin{array}{l}\text { Density } \\
(\mathrm{kg} / \mathrm{L})\end{array}$ & $\begin{array}{l}\mathrm{NO}_{3} \\
(\mathrm{~kg})\end{array}$ & $\begin{array}{l}\mathrm{NO}_{2} \\
(\mathrm{~kg})\end{array}$ & $\begin{array}{l}\text { TOC } \\
(\mathbf{k g})\end{array}$ & $\% \mathrm{TS}$ & $\begin{array}{l}\text { Oxide } \\
\text { (g/L) }\end{array}$ \\
\hline \multirow[t]{2}{*}{ Pre-boil Simulant } & 12.5 & 1.18 & $43.93(\mathrm{~T})^{* *}$ & $17.28(\mathrm{~T})$ & - & 26.59 & $264.06(\mathrm{~A})$ \\
\hline & & & & & & & $241.37(\mathrm{~T})$ \\
\hline \multirow[t]{4}{*}{ Post-boil Simulant } & 12.2 & 1.30 & 27.90 & $16.14(\mathrm{~A})$ & - & 38.16 & \\
\hline & & & $+15.43^{*}$ & & & & \\
\hline & & & $43.33(\mathrm{~A})$ & $17.28(\mathrm{~T})$ & & & \\
\hline & & & $43.93(\mathrm{~T})^{* *}$ & & & & \\
\hline \multirow[t]{4}{*}{ Glass-former } & $<1$ & 1.40 & 256.59 & - & - & 50.42 & $465.77(\mathrm{~A})$ \\
\hline & & & $+9.348^{*}$ & & & & \\
\hline & & & 265.93(A) & & & & $452.00(\mathrm{~T})$ \\
\hline & & & $253.45(\mathrm{~T})$ & & & & \\
\hline \multirow[t]{3}{*}{ Pre-sugar Slurry } & - & 1.37 & 283.42 & - & - & - & $428.86(\mathrm{~A})$ \\
\hline & & & $+24.77^{*}$ & & & & \\
\hline & & & $308.19(\mathrm{~A})$ & & & & $420.75(\mathrm{~T})$ \\
\hline \multirow[t]{4}{*}{ Post-sugar Slurry } & 3.67 & 1.37 & 283.67 & - & $55.02(\mathrm{~A})$ & 51.08 & $410.77(\mathrm{~A})$ \\
\hline & & & $+24.77^{*}$ & & & & \\
\hline & & & $308.44(\mathrm{~A})$ & & $50.10(\mathrm{~T})$ & & $402.72(\mathrm{~T})$ \\
\hline & & & $305.13(\mathrm{~T})$ & & & & \\
\hline
\end{tabular}

* Nitrate from zirconyl nitrate not accounted for by the nitrate analysis

**Target nitrate number with no nitrite contribution

(A) - Final value utilized for the analytical results

(T) - Calculated target amounts 
Table G-3 presents the average of the sample results as reported by the A\&PC Lab from the waste simulant, glass-formers, and the final slurry for Run 2-01. These averages were compared to the target oxide compositions and the percent differences were calculated. Upon comparison of the waste simulant sample results to the target composition, the analysis showed the following components exceeded their targets: $\mathrm{SiO}_{2}$ at $39.0 \%, \mathrm{Al}_{2} \mathrm{O}$ at $15.5 \%$, and $\mathrm{CaO}$ at $18.23 \%$. Upon comparison of the glass-formers to the target compositions, the following component exceeded its target: $\mathrm{SiO}_{2}$ at $9.06 \%$. The final slurry composition had one component that came out low when compared to its target composition: $\mathrm{ZrO}_{2}$ at $10.83 \%$.

Table G-3. Oxide Composition

\begin{tabular}{|c|c|c|c|c|c|c|c|c|c|c|c|c|}
\hline Oxides & $\begin{array}{l}\text { Target } \\
\text { Glass } \\
\text { (kg) }\end{array}$ & $\begin{array}{l}\text { Analyzed } \\
\text { Slurry } \\
(\mathrm{kg})\end{array}$ & $\begin{array}{l}\text { Diff. } \\
\text { (kg) }\end{array}$ & \% Diff. & $\begin{array}{c}\text { Target } \\
\text { Waste } \\
\text { Simulant } \\
\text { (kg) }\end{array}$ & $\begin{array}{c}\text { Analyzed } \\
\text { Waste } \\
\text { Simulant } \\
(\mathbf{k g})\end{array}$ & $\begin{array}{l}\text { Diff. } \\
\text { (kg) }\end{array}$ & $\%$ Diff. & $\begin{array}{l}\text { Target } \\
\text { Glass- } \\
\text { Formers } \\
\text { (kg) }\end{array}$ & $\begin{array}{l}\text { Analyzed } \\
\text { Glass- } \\
\text { Formers } \\
(\mathbf{k g})\end{array}$ & $\begin{array}{l}\text { Diff. } \\
\text { (kg) }\end{array}$ & \%Diff. \\
\hline $\mathrm{Al}_{2} \mathrm{O}_{3}$ & 43.20 & 42.17 & 1.03 & 2.38 & 22.39 & 25.86 & -3.47 & -15.48 & 20.81 & 20.50 & 0.30 & 1.46 \\
\hline $\mathrm{B}_{2} \mathrm{O}_{3}$ & 92.81 & 89.29 & 3.51 & 3.79 & 0.43 & 2.53 & -2.15 & -498.16 & 92.38 & 85.59 & 6.76 & 7.34 \\
\hline $\mathrm{CaO}$ & 3.46 & 4.13 & -0.67 & -19.37 & 3.46 & 4.09 & -0.63 & -18.23 & & & & \\
\hline $\mathrm{Fe}_{2} \mathrm{O}_{3}$ & 86.84 & 95.01 & -8.47 & -9.78 & 86.64 & 85.60 & 0.94 & 1.09 & & & & \\
\hline $\mathrm{K}_{2} \mathrm{O}$ & 36.00 & 32.86 & 3.14 & 8.72 & 29.30 & 26.79 & 2.51 & 8.57 & 6.70 & 6.39 & 0.30 & 4.55 \\
\hline $\mathrm{Li}_{2} \mathrm{O}$ & 26.71 & 26.23 & 0.48 & 1.79 & & 0.11 & -0.11 & & 26.71 & 27.14 & -0.43 & -1.61 \\
\hline $\mathrm{MgO}$ & 6.41 & 6.36 & 0.06 & 0.87 & 1.30 & 1.54 & -0.24 & -18.75 & 5.11 & 5.15 & -0.04 & -0.74 \\
\hline $\mathrm{MnO}$ & 5.90 & 6.05 & -0.15 & -2.55 & 4.10 & 3.98 & 0.12 & 3.01 & 1.80 & 1.79 & 0.01 & 0.80 \\
\hline $\mathrm{Na}_{2} \mathrm{O}$ & 57.60 & 56.35 & 1.25 & 2.16 & 36.00 & 33.32 & 2.68 & 7.43 & 21.60 & 20.63 & 0.97 & 4.47 \\
\hline $\mathrm{NiO}$ & 1.80 & 1.71 & 0.09 & 5.03 & 1.80 & 1.51 & 0.29 & 15.94 & & & & \\
\hline $\mathrm{P}_{2} \mathrm{O}_{5}$ & 8.64 & 8.84 & -0.20 & -2.26 & 8.64 & 7.88 & 0.76 & 8.84 & & & & \\
\hline $\mathrm{SO}_{3}$ & 1.66 & 2.57 & -0.91 & -54.96 & 1.66 & 2.15 & -0.49 & -29.82 & & & & \\
\hline $\mathrm{SiO}_{2}$ & 310.66 & 329.17 & -18.49 & -5.95 & 82.94 & 115.28 & -32.34 & -38.99 & 227.16 & 247.75 & -20.59 & -9.06 \\
\hline $\mathrm{TiO}_{2}$ & 5.75 & 5.61 & 0.15 & 2.55 & 2.88 & 3.48 & -0.60 & -20.80 & 2.88 & 2.90 & -0.02 & -0.78 \\
\hline $\mathrm{ZrO}_{2}$ & 24.70 & 22.02 & 2.68 & 10.83 & 15.34 & 13.82 & 1.52 & 9.91 & 9.29 & 9.21 & 0.08 & 0.86 \\
\hline Others & 6.99 & 4.84 & & & 7.42 & 4.80 & & & 0.00 & 0.00 & & \\
\hline Total & 718.85 & 733.22 & & & 304.20 & 332.80 & & & 414.43 & 427.06 & & \\
\hline
\end{tabular}




\subsection{Melter Operation}

The FHT contents were transferred to the MFT and feeding the melter began. After the first airlift, the melter was shut down due to plugging of the discharge section of the melter. The discharge section of the melter was cleared and feeding of the melter began again. Run 2-01 ended after 72 hours of operation. The remaining feed in the FHT was shimmed with nitric acid and utilized for Run 2-02.

The following key parameters are important for attaining steady state conditions in the melter and are monitored on a continuous basis:

- Feed Rate

- Cold Cap Coverage

- Internal Glass Temperature
- Plenum Temperature

- Redox

- Melter Power.

Monitoring these parameters on a continuous basis provided vital information on possible expected operational behavior from the melter in the Vitrification Facility. Melter operation for the Vitrification Test Facility (VTF) mini-melter is split into two modes of operation based on monitoring and controlling the previously stated key parameters. The first mode of melter operation (0-35 hours) is spent striving for the first steady state, while the second mode of operation is spent maintaining the first steady state. The key parameters mentioned above are discussed in the following sections.

The feed rate to the melter ranged from 6 to $33 \mathrm{~L} / \mathrm{hr}$, with approximately six interruptions to unplug the melter feed line to the melter. The feed rate started out at $24 \mathrm{~L} / \mathrm{hr}$ and went as high as $33 \mathrm{~L} / \mathrm{hr}$ within the four hours that it took to establish the cold cap. Upon establishing the cold cap, the feed rate to the melter was backed down to 10 to $20 \mathrm{~L} / \mathrm{hr}$ to maintain a cold cap coverage of 90 to $95 \%$. After 20 hours of operation, the feed rate to the melter dropped significantly to approximately $4 \mathrm{~L} / \mathrm{hr}$. Over the next 20 hours of operation, the feed rate to the melter ranged from 5 to $12 \mathrm{~L} / \mathrm{hr}$, maintaining the cold cap coverage at 90 to $95 \%$. For the last 30 hours of melter operation, the cold cap coverage was consistently between a range of 90 to $95 \%$. There was one exception during the last 30 hours of operation where the cold cap was $78 \%$. This could be explained by a feed interruption to the melter due to the feed line plugging. The feed rate for the last 30 hours of operation was inconsistent, ranging from 5 to $25 \mathrm{~L} / \mathrm{hr}$.

The plots of the feed rate and cold cap coverage versus time for the melter are presented in Figures G-1 and G-2.

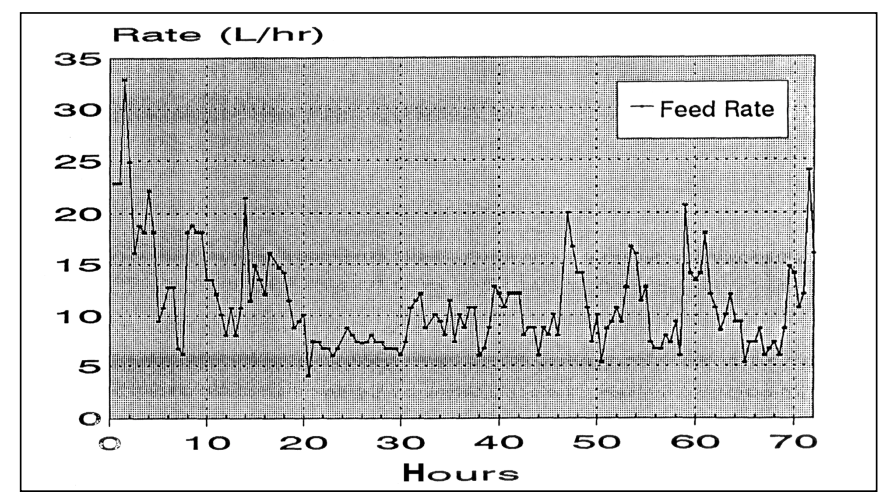

Figure G-1. Feed Rate vs. Time

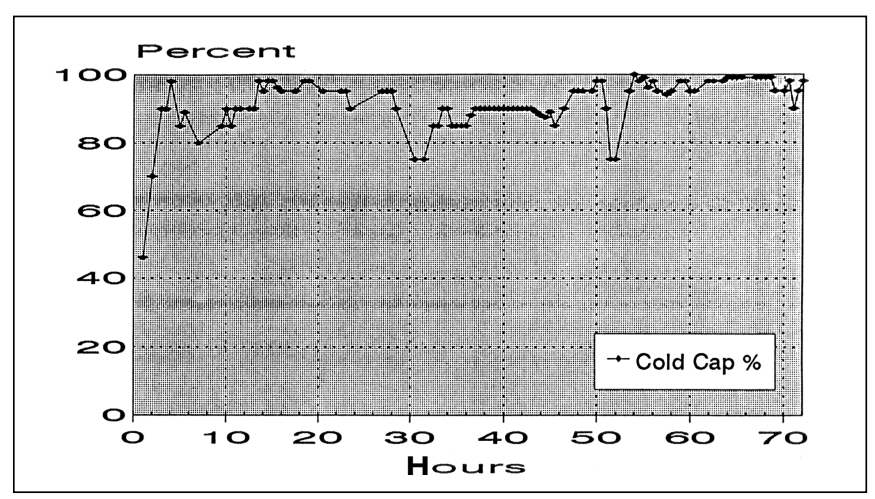

Figure G-2. Percent Cold Cap Coverage vs. Time 
The plenum temperature for the first four hours of melter operation dropped from $930^{\circ} \mathrm{C}$ to the desired plenum temperature of $550^{\circ} \mathrm{C}$. The reason for this drop in the plenum temperature can be explained by the formation of the cold cap in the melter. The plenum temperature for Run 2-01 remained fairly constant throughout the 72 hours of operation. There are a few occurrences where the plenum temperature breached the expected operating band of $525^{\circ}$ to $575^{\circ} \mathrm{C}$. These occurrences can be explained by relating plenum temperature to the cold cap coverage. When the plenum temperature was operating on the low side, the cold cap coverage in the melter was approximately 95 to $99 \%$. The operation of the plenum temperature on the high side would suggest that the cold cap coverage was 85 to $90 \%$.

Figure G-3 shows plenum temperature plotted versus time.

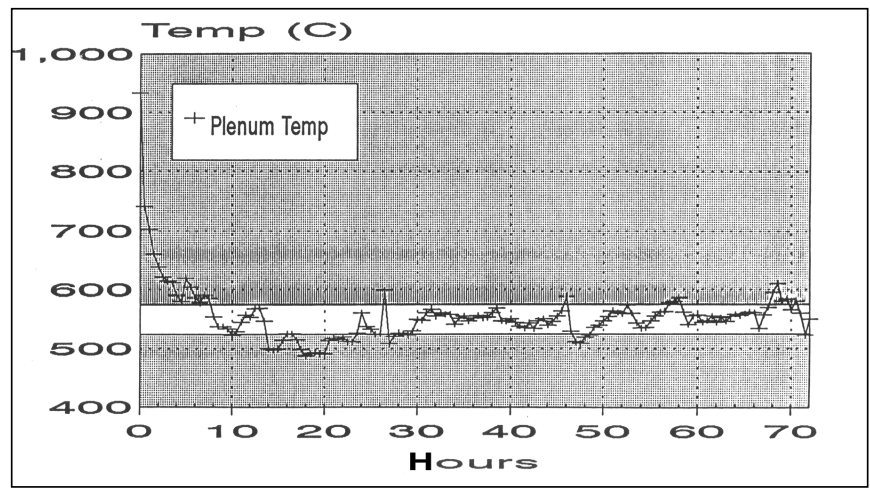

Figure G-3. Plenum Temperature vs. Time

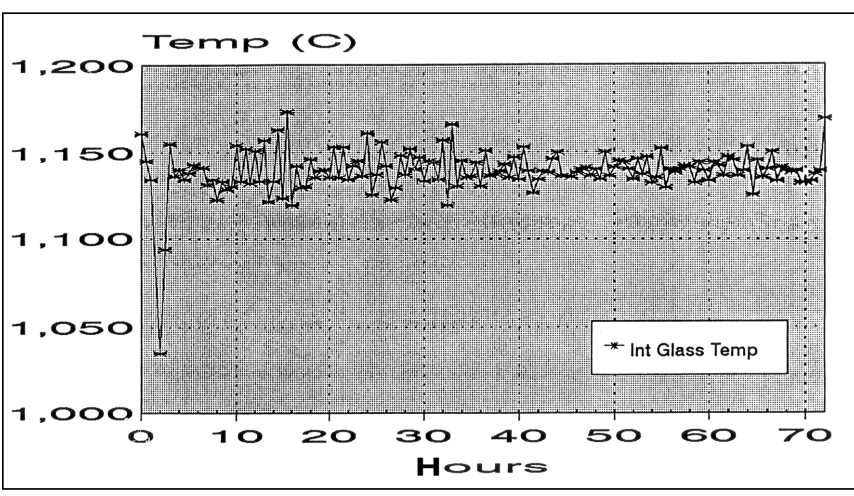

Figure G-4. Internal Glass Pool Temperature vs. Time

The ferrous-to-ferric ratio, measured in glass samples from the airlifts, is utilized as an indicator of how oxidizing or reducing the glass is. Due to the oxidizing nature of the glass for Run 2-01, the ferrous-to-ferric ratio could not be measured accurately by the A\&PC Lab. However, the airlift samples from this run were turned in to confirm the ferrous-to-ferric ratio was less than $0.01(+10 \%$ error in the measurement).

The internal glass pool temperature for Run 2-01 remained consistent throughout melter operation past the first two hours. The operating temperature ranged from $1,125^{\circ}$ to $1,175^{\circ} \mathrm{C}$. The one exception, where the internal glass temperature dropped to $1,040^{\circ} \mathrm{C}$, could be explained by the melter power being off to unplug the melter feed line. Figure G-4 shows the internal glass pool temperature plotted verses time.

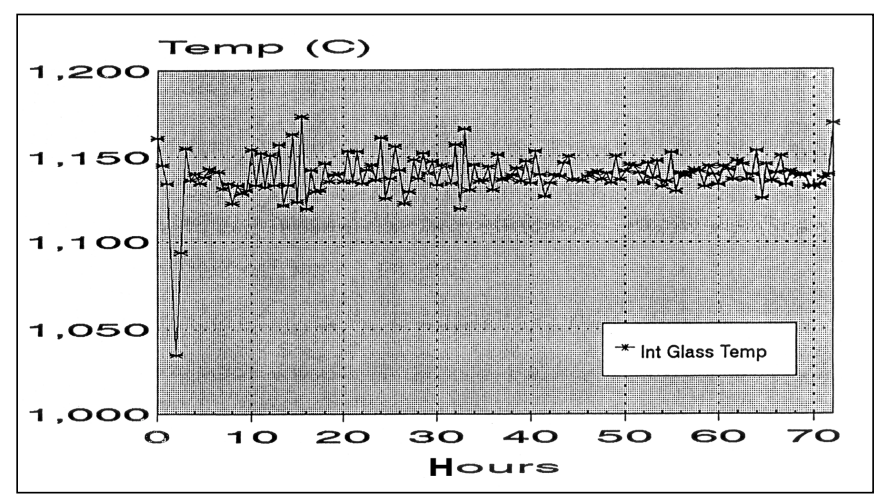

Figure G-5. Melter Power vs. Time
Melter power is plotted verses time in Figure G-5. This graph indicates that the electrode power for the 72 hours of melter operation ranged from 1 to 15.8 $\mathrm{kW}$ and that the power to the melter was shut off a total of six times. Taking a closer look at the graph and throwing out the high and low values, the average electrode power ranged between 4 and $10 \mathrm{~kW}$. 


\subsection{Summary}

During the 70 hours of melter operation for Run 2-01, there were no indications that foaming had occurred in the melter. Upon comparison of the normalized results from airlift glass samples to the target compositions, the airlift glass samples were high in $\mathrm{Fe}_{2} \mathrm{O}_{3}$ and low in $\mathrm{B}_{2} \mathrm{O}_{3}, \mathrm{~K}_{2} \mathrm{O}$, and $\mathrm{ZrO}_{2}$. When a comparison was made of the normalized data for the slurry samples to the target composition, the slurry was low in $\mathrm{B}_{2} \mathrm{O}_{3}, \mathrm{~K}_{2} \mathrm{O}$, and $\mathrm{ZrO}_{2}$; and high in $\mathrm{Fe}_{2} \mathrm{O}_{3}$. When these percent differences from the slurry and airlift glass samples are compared to the criteria defined in the Waste Acceptance Preliminary Specifications (WAPS), they fall within the acceptable tolerances allowed for each of these components.

The redox data point for Run 2-01 is shown in Figure 17 of Section 5.3.1. 


\section{APPENDIX H:}

\subsection{SVS-III RUN 2-02}

\subsection{Objectives}

SVS-III Run 2-02 concentrated on the following objectives:

- Targeting a redox ratio of $<0.01$

- Observing high oxidizing conditions in the SVS-III mini-melter

- Targeting an IFO of 3.2.

\subsection{Feed Preparation}

No new feed was prepared for this test run. A volume of 944.2 L of slurry from Run 2-01 was shimmed with $42.2 \mathrm{~kg}$ of $35 \%$ nitric acid. An IFO of 3.2 was selected to target a ferrous-to-ferric ratio of less than 0.01 for this run in order to investigate melter behavior under highly oxidizing conditions. Potential melter problems include reboil and foaming, where rapid increases in glass pool temperature and volume can occur.

\subsection{Melter Operation}

SVS-III Test Run 2-02 ran for a total of 67 hours. The plenum temperature, feed rate, cold cap coverage, melter power, internal glass pool temperature, and ferrous-to-ferric ratio were monitored throughout the run to maintain steady state operation.

After 35 minutes of feed delivery to the melter, foaming was observed and the glass pool temperature peaked at $1,200^{\circ} \mathrm{C}$. The feed rate was immediately reduced from $35 \mathrm{~L} / \mathrm{hr}$ to $\sim 15 \mathrm{~L} / \mathrm{hr}$. The melter stabilized 30 minutes later with a glass pool temperature of $1,140^{\circ} \mathrm{C}$ and a plenum temperature of $665^{\circ} \mathrm{C}$. Melt characteristics and melter parameters were monitored throughout the duration of the foaming and are plotted as functions of time in Figures H-1 through H-7. Glass melt temperature (underglass temperature) is shown in Figure $\mathrm{H}-1$, plenum temperature is shown in Figure $\mathrm{H}-2, \mathrm{NO}_{\mathrm{x}}$ concentration in ppm is shown in Figure $\mathrm{H}-3$, and melter pressure (inches of water) is shown in Figure H-4. Figures H-5 through H-7 show melter power in kilowatts, melter electrode volts, and melter electrode amps, respectively, as functions of time.

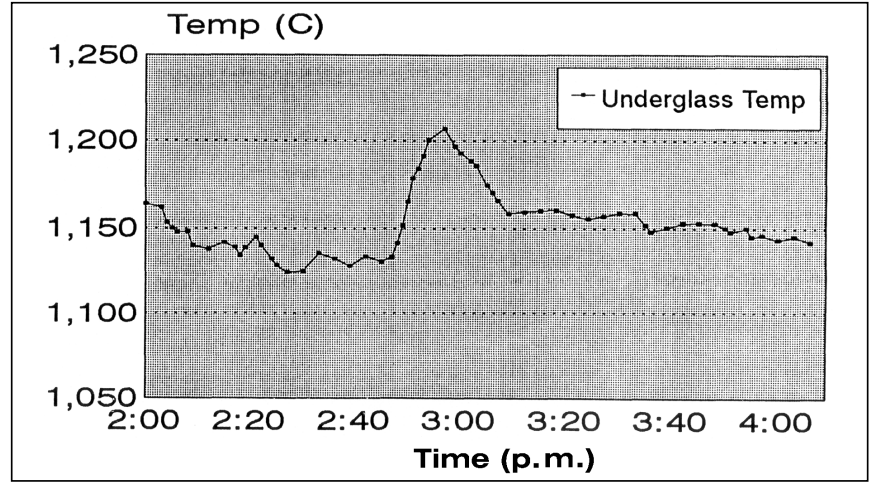

Figure H-1. Feed Rate vs. Time

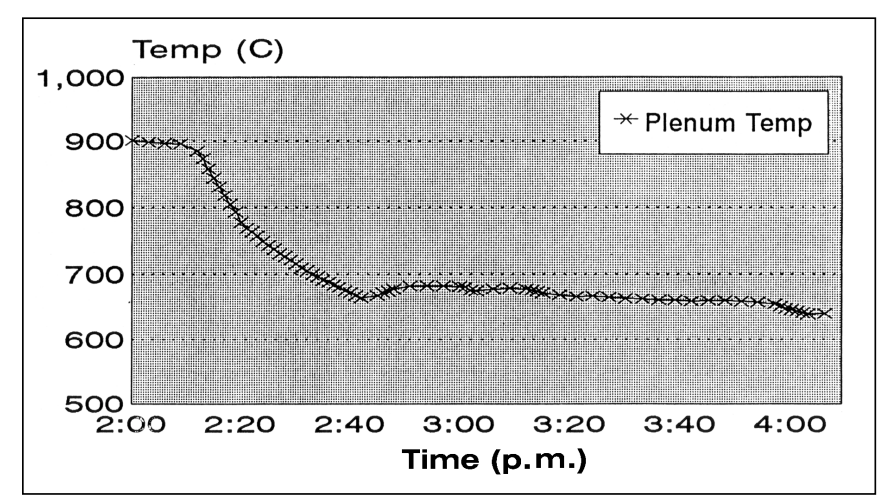

Figure H-2. Plenum Temperature vs. Time for Foaming Incident 


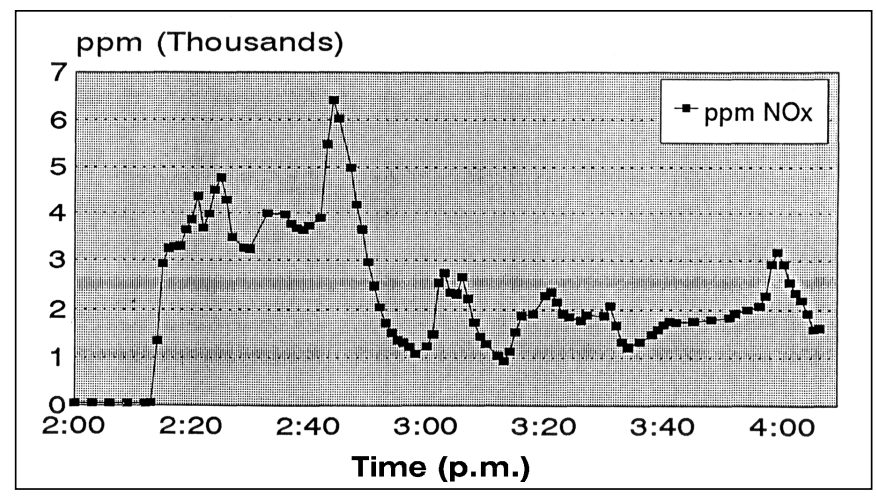

Figure H-3. NOx Concentration vs. Time for Foaming Incident

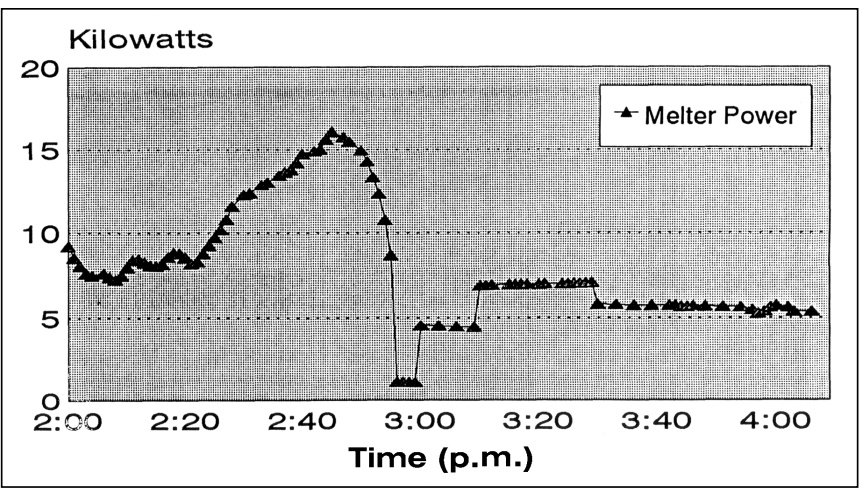

Figure H-5. Melter Power (kW) vs. Time for Foaming Incident

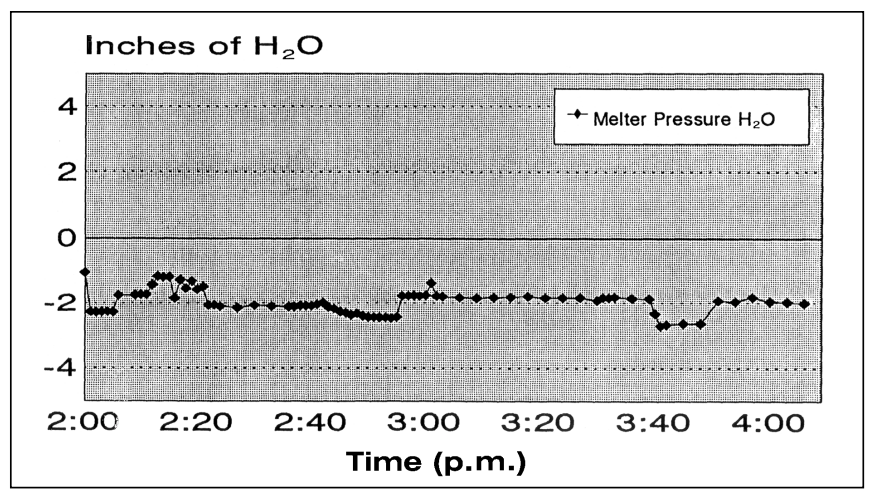

Figure H-4. Melter Pressure vs. Time for Foaming Incident

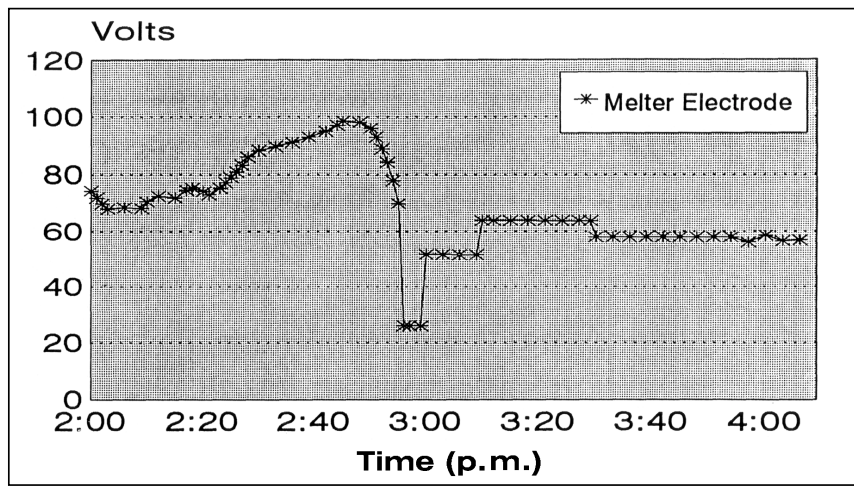

Figure H-6. Melter Power (volts) vs. Time for Foaming Incident

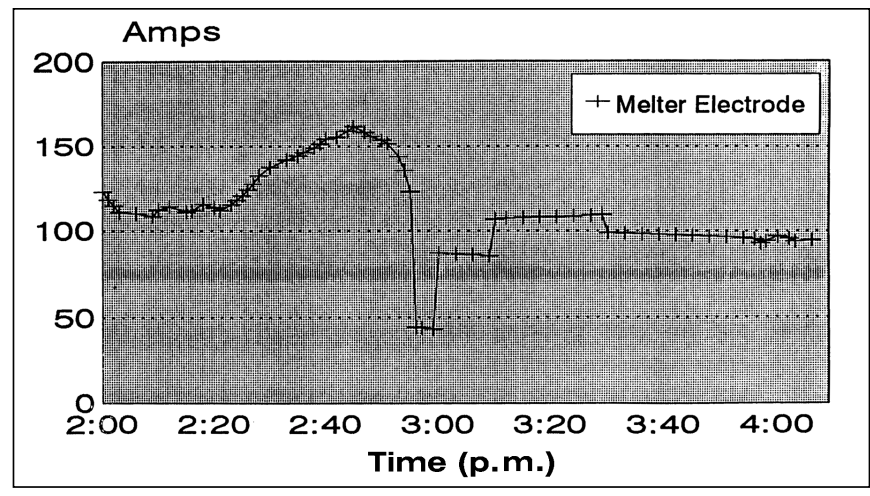

Figure H-7. Melter Power (amps) vs. Time for Foaming Incident 
The foaming was most likely the result of a rapid feed rate at startup rather than a response to redox because it occurred within the first 35 minutes of melter operation and was quickly controlled by reducing the feed rate. At no other time throughout the run did foaming occur.

\subsubsection{Feed Rate, Cold Cap, and Plenum Temperature}

The feed rate, cold cap coverage, and plenum temperature are interdependent and controlled by the rate of feed delivery to the melter. At the beginning of the run, the feed rate is high to establish a cold cap over the glass melt. Once the cold cap is established, the feed rate is reduced to within the target range of 15 to $20 \mathrm{~L} /$ hr. The extent of the cold cap over the melt determines the plenum temperature, with $\sim 85 \%$ cold cap coverage targeted to maintain a plenum temperature in the $500^{\circ}$ to $600^{\circ} \mathrm{C}$ range.

During Run 2-02, the feed rate, shown in Figure H-8, was initiated at $\sim 30 \mathrm{~L} / \mathrm{hr}$, then decreased in order to maintained the average in the target range within the first three hours of the run, then the feed rate was maintained between 10 and $20 \mathrm{~L} / \mathrm{hr}$ throughout. The plenum temperature, shown in Figure H-9, decreased from $900^{\circ}$ to $600^{\circ} \mathrm{C}$ during the first five hours of the run, then stabilized around $550^{\circ} \mathrm{C}$ for the remainder of the run.

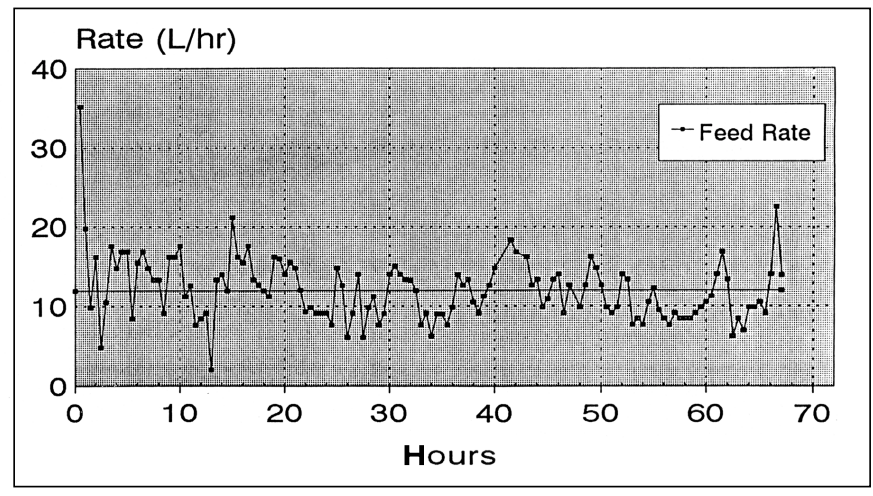

Figure H-8. Feed Rate vs. Time

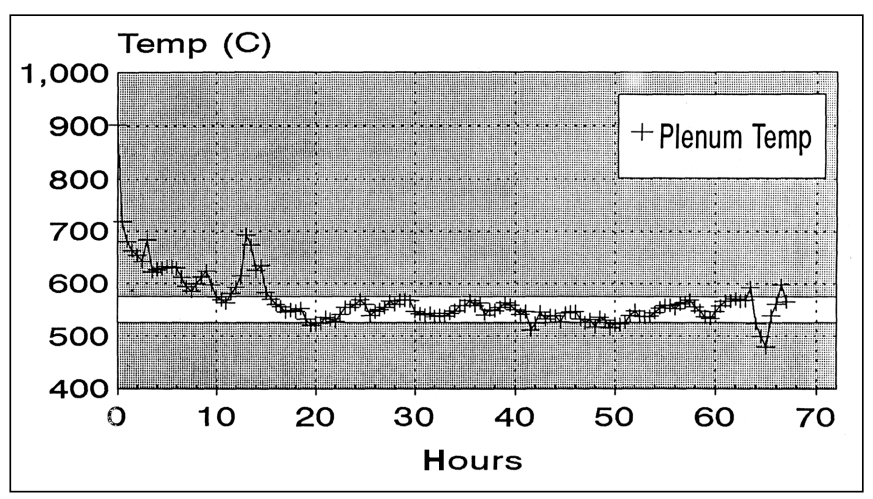

Figure H-9. Plenum Temperature vs. Time

Figure H-10 shows cold cap coverage as percent coverage vs. time. Coverage was irregular during the first 40 hours of the run, varying between 30 and $100 \%$. For the remainder of the run, cold cap coverage was stable at 95 to $99 \%$. The internal glass temperature is shown in Figure H-11. The temperature was maintained within $20^{\circ} \mathrm{C}$ throughout the 67 hours of melter operation, ranging between $1,130^{\circ}$ and $1,150^{\circ} \mathrm{C}$. Melter power, from Figure H-12, averaged around $8 \mathrm{~kW}$ for the entire run time.

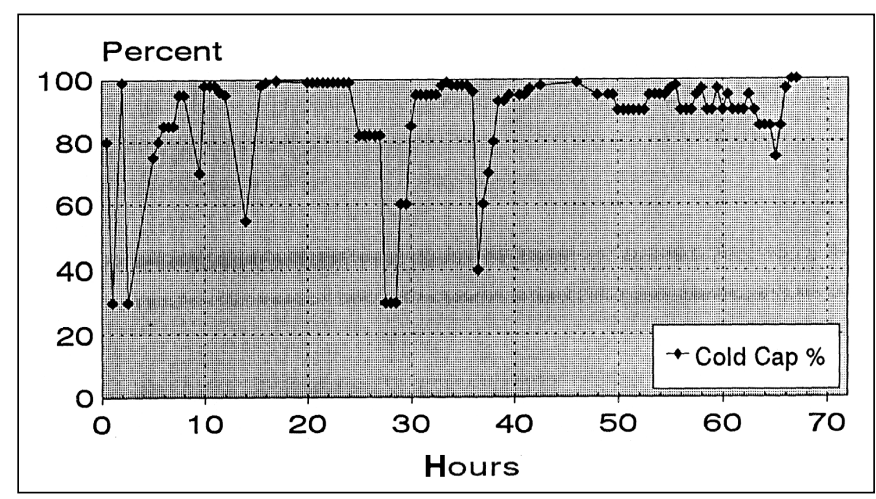

Figure H-10. Percent Cold Cap Coverage vs. Time

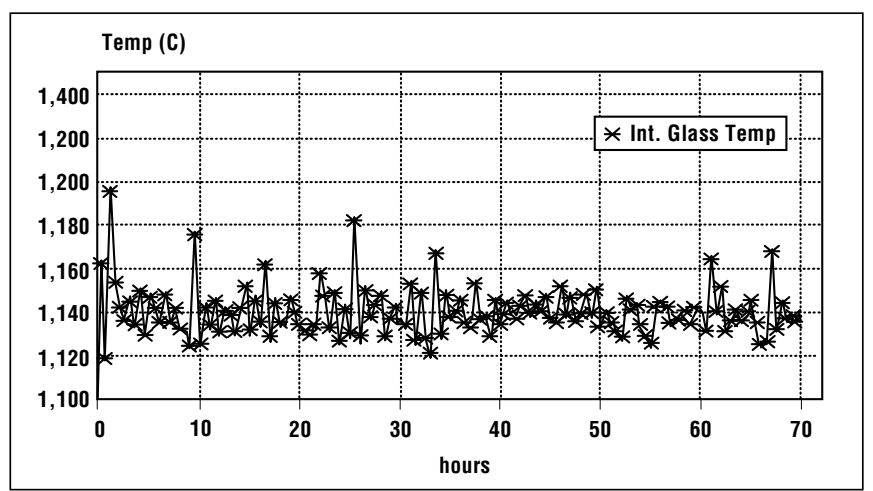

Figure H-11. Internal Glass Pool Temperature vs. Time 


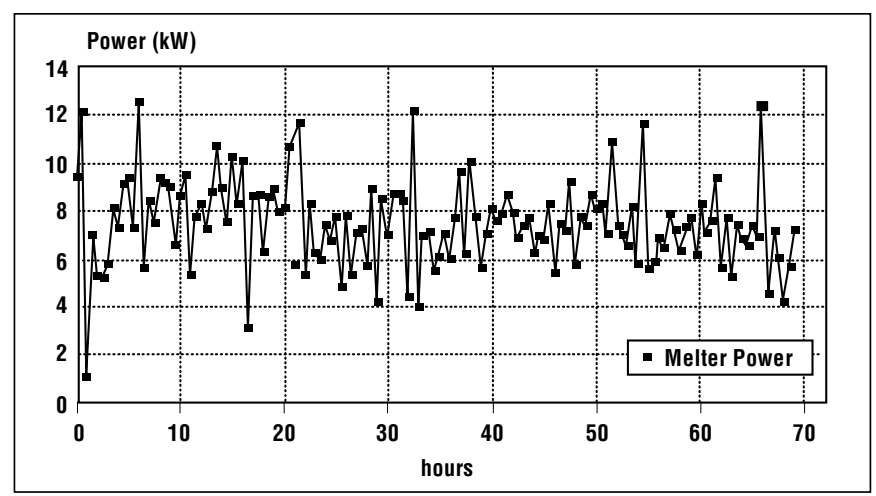

Figure H-12. Melter Power vs. Time

\subsection{1 $\mathrm{Fe}^{+2} / \mathrm{Fe}^{+3}$ Ratio}

The target ferrous-to-ferric ratio for SVS-III Run 2-02 was $<0.01$ in order to establish a data point at the extreme oxidizing end of the redox spectrum and, if possible, identify an $\mathrm{Fe}^{+2} / \mathrm{Fe}^{+3}$ ratio cut-off point for melting glass without foaming or reboil. Figure $\mathrm{H}-13$ shows the $\mathrm{Fe}^{+2} / \mathrm{Fe}^{+3}$ ratio of the glass produced in the melter as a function of melter operation time. Of seven airlift glass samples analyzed for $\mathrm{Fe}^{+2} / \mathrm{Fe}^{+3}$, three ratios were below the detectability limit of 0.01 , three were measured as 0.01 , and one was measured as 0.05 .

\subsection{Summary}

The focus of SVS-III Run 2-02 was on the effects of extremely oxidizing conditions $\left(\mathrm{Fe}^{+2} / \mathrm{Fe}^{+3}<<0.01\right)$ on melter operation and glass properties. Foaming was observed in the melter at the startup of feed delivery; most likely the result of a rapid feed rate rather than of a high-oxidation state of the glass melt. The melter was quickly brought under control by reducing the feed rate, and no further foaming was observed.

Of the several airlift glass samples analyzed, the ferrous-to-ferric ratio was 0.01 or less for the majority of the samples and 0.05 for only one. As the lower detectable limit is a ratio of 0.01 , finer distinctions among redox states cannot be made. Compositionally, the glass product was very close to the target composition with none of the eight major species greater than $8 \%$ above or below their target concentration values. 


\section{APPENDIX I:}

\subsection{TEST APPARATUS}

61-C-16 Venturi Scrubber (VS) - Quenches off-gas with water

61-D-01 Slurry Mix Tank (SMT) — Primary purpose is to mix waste simulant and the glass-formers

61-D-04 Feed Hold Tank (FHT) — Used primarily to mix and boil down the waste simulant

61-D-06 Melter Feed Tank (MFT) — Meters slurry into the SVS-III melter

61-D-07 Scrubber Water Collection Tank (SWCT) - Collects excess process water prior to recycling into the process and / or disposal

61-D-08 Condensate Hold Tank (CHT) - Feeds and collects the water that is used to quench off-gas in the venturi scrubber (VS)

61-V-01 SVS-III Melter - A 1/7th scale model, based on surface area, of the melter used in the actual Vitrification Facility; processes slurry into glass

61-V-08 Vac-U-Max ${ }^{\circledR}$ - Pneumatic transfer system that is used to move solids into the SMT

61-V-14 Fluidized Bed Reactor - Combines off-gas and ammonia at an elevated temperature to break down nitrous oxides into nitrogen and water

61-V-17 High-Efficiency Mist Eliminator (HEME) — Reduces the amount of water in the off-gas that will go to the blower 
This page intentionally blank. 
Scaled Vitrification System III (SVS III) Process Development and Laboratory Tests at the West Valley Demonstration Project 